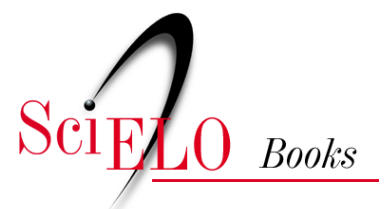

\title{
História da saúde no Rio de Janeiro
}

instituições e patrimônio arquitetônico (1808-1958)

\author{
Ângela Porto \\ Gisele Sanglard \\ Maria Rachel Fróes da Fonseca \\ Renato da Gama-Rosa Costa \\ (orgs.)
}

\section{SciELO Books / SciELO Livros / SciELO Libros}

PORTO, Â., SANGLARD, G., FONSECA, M.R.F., and COSTA, R.G.R., orgs. História da saúde no Rio de Janeiro: instituições e patrimônio arquitetônico (1808-1958) [online]. Rio de Janeiro: Editora FIOCRUZ, 2008, 167 p. ISBN: 978-85-7541-599-3. Available from: doi: 10.7476/9788575415993. Also available in ePUB from: http://books.scielo.org/id/7f83x/epub/porto-9788575415993.epub.

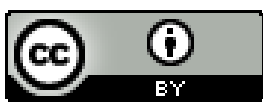

All the contents of this work, except where otherwise noted, is licensed under a Creative Commons Attribution 4.0 International license.

Todo o conteúdo deste trabalho, exceto quando houver ressalva, é publicado sob a licença $\underline{\text { Creative Commons }}$ Atribição 4.0. 


\section{História da Saúde no Rio de Janeiro}




\section{Fundação Oswaldo Cruz}

Presidente

Paulo Marchiori Buss

Vice-Presidente de Ensino, Informação

e Comunicação

Maria do Carmo Leal

\section{Editora Fiocruz}

Diretora

Maria do Carmo Leal

Editor Executivo

João Carlos Canossa Mendes

Editores Científicos

Nísia Trindade Lima

Ricardo Ventura Santos

Conselho Editorial

Carlos E. A. Coimbra Jr.

Gerson Oliveira Penna

Gilberto Hochman

Ligia Vieira da Silva

Maria Cecília de Souza Minayo

Maria Elizabeth Lopes Moreira

Pedro Lagerblad de Oliveira

Ricardo Lourenço de Oliveira 


\title{
História da Saúde no Rio de Janeiro \\ instituições e patrimônio arquitetônico (1808-1958)
}

\author{
Ângela Porto \\ Gisele Sanglard \\ Maria Rachel Fróes da Fonseca \\ Renato da Gama-Rosa Costa \\ organizadores
}


Copyright () 2008 dos autores

Todos os direitos desta edição reservados à

Fundação Oswaldo Cruz/EDitora

ISBN: 978-85-7541-167-4

Capa, projeto gráfico e editoração eletrônica

Fernando Vasconcelos

Revisão

Irene Ernest Dias

Glossário

Atiele Lopes

Fotografia

Roberto Jesus Oscar

Vinícius Pequeno de Souza

Capa

Fachada da antiga sede da Sociedade Espanhola de Beneficência, [1930]. Acervo Sociedade Espanhola de Beneficência

Maternidade de Laranjeiras, [s.d.]. Acervo Museu da Imagem e do Som, RJ

Pavilhão de Diversões, Colônia de Curupaity, [s.d.]. Acervo Cpdoc/FGV

Contracapa

Vista da Exposição, 1922. Foto Augusto Malta. Acervo Arquivo Geral da Cidade do Rio de Janeiro

Catalogação na fonte

Centro de Informação Científica e Tecnológica

Biblioteca da Escola Nacional de Saúde Pública Sergio Arouca

P853h Porto, Ângela (org.)

História da saúde no Rio de Janeiro: instituições e patrimônio arquitetônico (1808-1958). / organizado por

Ângela Porto, Gisele Sanglard, Maria Rachel Fróes da

Fonseca, et al. - Rio de Janeiro : Editora FIOCRUZ, 2008.

172 p., il. color.

1. Saúde Pública - história - Rio de Janeiro.

2. Arquitetura de Instituições de Saúde - história. I.

Porto, Ângela (org.). II. Sanglard, Gisele (org.). III. Fonseca,

Maria Rachel Fróes da (org.). IV. Título.

$$
\text { CDD - 22.ed. - 614.098153 }
$$

\section{8}

Editora Fiocruz

Av. Brasil, 4036, 1ํandar, sala 112

Manguinhos

21040-361 - Rio de Janeiro, RJ

Tels: (21) 3882-9039 e 3882-9041

Fax: (21) 3882-9007

e-mail: editora@fiocruz.br

http://www.fiocruz.br/editora 


\section{Autores}

Ângela Porto (organizadora)

Mestra em história do Brasil pela Universidade Federal Fluminense (UFF) e doutora em saúde coletiva pelo Instituto de Medicina Social da Universidade do Estado do Rio de Janeiro (IMS/Uerj). Pesquisadora do Departamento de Pesquisa da Casa de Oswaldo Cruz (COC/Fiocruz), editora da seção Imagens da revista História, Ciências, Saúde - Manguinhos e docente do Programa de Pós-Graduação em História das Ciências e da Saúde da COC/Fiocruz.

\section{Cristina Maria Oliveira Fonseca}

Mestra em história pela Universidade Federal Fluminense (UFF) e doutora em ciência política pelo Instituto Universitário de Pesquisas do Rio de Janeiro (Iuperj). Pesquisadora da Casa de Oswaldo Cruz (COC/Fiocruz).

Gisele Sanglard (organizadora)

Mestra em história social da cultura pela Pontifícia Universidade Católica (PUC-RJ) e doutora em história das ciências e da saúde pela Casa de Oswaldo Cruz (COC/Fiocruz). Pesquisadora visitante na COC (FaperjFiocruz).

Maria Rachel Fróes da Fonseca (organizadora)

Mestra em história pela Universidade Federal Fluminense (UFF) e doutora em história social pela Universidade de São Paulo (USP). Pesquisadora do Departamento de Pesquisa da Casa de Oswaldo Cruz (COC/Fiocruz), onde atualmente coordena o Programa de Pós-Graduação em História das Ciências e da Saúde.

Renato da Gama-Rosa Costa (organizador)

Especialista em história da arte e arquitetura no Brasil pela Pontifícia Universidade Católica (PUC-RJ), mestre em arquitetura e doutor em urbanismo pelo Programa de Pós-Graduação em Arquitetura da Universidade Federal do Rio de Janeiro (FAU/UFRJ). Pesquisador do Departamento de Patrimônio Histórico da Casa de Oswaldo Cruz (COC/Fiocruz). Secretário do International Committee for Documentation and Conservation of Buildings, Sites and Neighborhoods of the Modern Movement (Docomomo), representação Rio de Janeiro-Brasil. 


\section{众 COBRA TECNOLOGIA}

A Cobra Tecnologia foi a primeira empresa a atuar no desenvolvimento, na produção e comercialização de tecnologia nacional, contribuindo para que esse espírito empreendedor genuinamente brasileiro pudesse evoluir ao longo dos anos. O desenvolvimento aconteceu e a essência nunca foi perdida. O objetivo? Buscar um compromisso que está acima das expectativas do mercado consumidor. O compromisso da Cobra Tecnologia era, e sempre será, com o Brasil.

Existe um elemento comum entre o mundo e as empresas que dele fazem parte. Um elemento capaz de transformar, girar, criar caminhos, sentidos, direções. Capaz de fazer acontecer e, antes de tudo, sonhar com o passado, sonhar no presente, sonhar pelo futuro. Sonhos que se unem para dar voz, cor e forma à capacidade ilimitada de um personagem especial, conhecido por todos nós. Um elemento que está presente não só nos corredores empresariais, mas também em todos os universos e esferas da sociedade: o ser humano.

O raciocínio é simples. Sem o elemento comum, não é possível sonhar. Sem sonhos, não acontecem realizações. Sem realizações, não existe sociedade. E, sem sociedade, como podem existir empresas? Faz parte de uma visão estratégica inteligente entender que as pessoas são o alicerce fundamental dos projetos para o futuro. O elemento comum é o fator determinante que pauta qualquer ação cidadã. E esta não pode ser apenas teoria ou protocolo. Tem que se traduzir em educação, cultura, meio ambiente, satisfação profissional, qualidade de vida e conscientização. Responsabilidade social significa transformar pessoas, sociedades e empresas. E, sem dúvida, transformar o mundo.

A Cobra acredita que o incentivo a instituições que beneficiam as comunidades menos favorecidas e contribuem para a formação de cidadãos plenos é, sem dúvida, uma forma de colaborar efetivamente no desenvolvimento do país. A empresa apóia a realização de projetos, no âmbito do Rio de Janeiro, que estimulem o interesse da população por seus bens culturais e ampliem seu acesso a tais bens.

Em 2008 identificamos no projeto "História da Saúde no Rio de Janeiro: instituições e patrimônio arquitetônico (1808-1958)" um valor inestimável para a reconstrução, com base na arquitetura hospitalar, da história da saúde neste município. Acreditando na contribuição que este volume e este CD-ROM adicionarão à nossa literatura e a bibliotecas públicas acessadas por estudantes e profissionais de áreas diversas, a Cobra Tecnologia tem orgulho em investir neste magnífico projeto.

Diretoria Executiva - Cobra Tecnologia S.A. 


\section{Sumário}

$\begin{array}{ll}\text { Prefácio } & 11\end{array}$

$\begin{array}{ll}\text { Apresentação } & 13\end{array}$

1. Memória, História e Patrimônio Cultural da Saúde: uma história possível 17

Gisele Sanglard e Renato da Gama-Rosa Costa

2. A Saúde Pública no Rio de Janeiro Imperial 31

Maria Rachel Fróes da Fonseca

3. A Primeira República e a Constituição de uma Rede Hospitalar no Distrito Federal

Gisele Sanglard

4. Política e Saúde: diretrizes nacionais e assistência médica no Distrito Federal no pós-1930

Cristina M. Oliveira Fonseca

5. Arquitetura e Saúde no Rio de Janeiro

Renato da Gama-Rosa Costa

Imagens Contemporâneas

Glossário 


\section{Prefácio}

É com satisfação que vemos esta obra ser publicada no mesmo ano em que a Casa de Oswaldo Cruz assume a coordenação regional da rede História e Patrimônio Cultural da Saúde. Reunindo 11 países da América Latina e Caribe, o propósito dessa rede é promover a articulação da dimensão cultural dos processos individuais e coletivos da saúde com a identificação, a valorização e o uso social do patrimônio histórico e científico.

Fruto de um trabalho em equipe, neste volume está analisada e registrada a trajetória de um notável conjunto de instituições, evidenciando a centralidade da saúde no Rio de Janeiro, cidade que, desde a vinda da família real no início do século XIX e até a mudança da capital da República em 1960, desempenhou um inequívoco protagonismo político e cultural, irradiado para o restante do país.

A originalidade do conjunto de reflexões aqui apresentadas reside na utilização da perspectiva histórica para se compreender a relação entre o pensamento médico-científico e a arquitetura das instituições médico-hospitalares. Desse desafio emerge a sugestão, entre outras, de que a materialidade das práticas e conhecimentos médicos pode ser também reconhecida visualmente no concreto das edificações de engenheiros e arquitetos. Estes participaram da transformação do hospital, de espaço de assistência aos pobres, em instituição de cura, objeto da intervenção médica, reproduzindo aqui, de forma similar, o processo ocorrido em outros países ocidentais desde o século XVIII.

Por meio de verbetes e imagens, os autores apresentam uma cartografia - não exaustiva - das instituições que por diferentes maneiras e em distintos períodos estiveram vinculadas à saúde, ao longo de um século e meio. Surpreendem o número e a diversidade de funções, concepções e práticas, reveladores de uma rica experiência coletiva ainda a ser explorada por outros estudos.

Ao ampliar os horizontes da pesquisa histórica em saúde, esta coletânea cumpre o papel de estimular políticas e ações de preservação do patrimônio em suas múltiplas dimensões, o qual, como assinalam os autores, permanece em risco de desaparecer caso não conte com a devida atenção das autoridades ao seu valor social, científico e cultural.

Obra de inestimável valor para um público amplo, revela uma das formas de contribuirmos para a construção e fortalecimento de identidades das instituições, dos profissionais da saúde e de seus principais agentes e movimentos sociais, que nele poderão reconhecer elementos de grande relevância simbólica e material, e de construção da cidadania. 


\section{Apresentação}

História da Saúde no Rio de Janeiro: instituições e patrimônio arquitetônico (1808-1958) é fruto de um projeto coletivo que teve por objetivo principal identificar e tornar público o conjunto de bens edificados que compõem o patrimônio cultural da saúde na cidade. Ao realizarmos a pesquisa da história institucional e arquitetônica de hospitais, instituições de assistência médica e institutos de pesquisa científica criados desde o início do século XIX até meados do XX, procuramos contribuir com ações em torno da preservação do patrimônio científico e cultural da saúde. Muitas das instituições aqui relacionadas já tiveram suas edificações tombadas, outras tantas se encontram em processo de tombamento, sem que isso signifique, no entanto, que estejam devidamente preservadas. A maioria delas ainda não teve esse destino e está desprotegida, ou mesmo descaracterizada em relação ao projeto original; outras tiveram a sede transferida ou, como é o caso da Faculdade de Medicina na Praia Vermelha, totalmente demolida.

Este estudo partiu de um levantamento realizado em 1994 pelo arquiteto Benedito Tadeu de Oliveira, do Departamento de Patrimônio Histórico da Casa de Oswaldo Cruz (COC), por Jaime Benchimol e por mim, ambos do Departamento de Pesquisa deste mesmo centro de pesquisa, documentação e informação. Naquele momento, tínhamos como objetivo listar e identificar os edifícios tombados ou em processo de tombamento - nas instâncias municipal, estadual e federal - ligados à saúde na cidade do Rio de Janeiro e, sobretudo, aqueles que se encontravam desprotegidos. Esse levantamento inicial partiu da proposta do prof. Paulo José Pardal, pesquisador, membro do Instituto Histórico e Geográfico Brasileiro (IHGB) e do Instituto Estadual de Patrimônio Cultural (Inepac/RJ), defensor incansável do patrimônio histórico desta cidade, a cuja memória dedicamos este trabalho.

À relação inicial foram acrescidos outros prédios identificados em pesquisa desenvolvida por Renato da Gama-Rosa Costa e Gisele Sanglard, que objetiva o estudo da constituição da Assistência Pública na capital federal, na República Velha, e nas ações da Divisão de Obras do Ministério da Saúde, no pós1930; e diversas instituições, especialmente as academias de ciência, pesquisadas no âmbito do projeto do Dicionário Histórico-Biográfico das Ciências da Saúde no Brasil (1832-1930), coordenado por Maria Rachel Fróes da Fonseca.

Sem a pretensão de esgotar a imensa lista que de início nos impusemos, ou mesmo de tentar dar conta da totalidade das instituições e dos bens edificados, apresentamos, por ora, um conjunto expressivo de instituições e as principais edificações que compõem o patrimônio arquitetônico da saúde no município do Rio de Janeiro, com o objetivo de evidenciá-los e conferir-lhes o devido reconhecimento.

Buscamos destacar diversas categorias representativas do patrimônio cultural e científico da saúde no Rio de Janeiro: estabelecimentos médicos, hospitais, centros hospitalares, lazaretos, leprosários, nosocômios 
e hospícios, instituições de pesquisa, laboratórios, instituições de ensino médico, estabelecimentos terapêuticos, órgãos públicos, associações e academias médico-científicas. Identificadas as principais instituições e respectivos edifícios relevantes para a história da saúde na cidade, procedemos ao levantamento de informações e imagens nos principais arquivos e bibliotecas mantenedores de acervos referenciais. Nem todas as instituições foram receptivas à idéia de fazer parte deste trabalho, outras não dispunham de documentação suficiente para recuperar sua história, mas estiveram de portas abertas para nossa equipe de pesquisa. Isso poderá deixar transparecer ao leitor uma certa heterogeneidade de conteúdo, se comparar o verbete de uma instituição com outra, ou mesmo perceber a ausência de reconhecidas instituições. Tais ocorrências são totalmente alheias à nossa vontade e não devem ser imputadas à incúria na pesquisa.

Percorrer a trajetória dessas instituições nos permitiu conhecer ainda mais a fundo a história da saúde no país, em especial as características e as transformações pelas quais a assistência hospitalar passou ao longo dos séculos XIX e XX. A arquitetura das edificações reflete todo esse processo, na medida em que é reveladora do conhecimento médico do período e da relação que se estabelecia entre saúde e doença. Estilos arquitetônicos adotados na construção de hospitais deixam transparecer a concepção e a forma de tratamento de uma determinada enfermidade à sua época. Assim, o modelo pavilhonar será substituído pelo monobloco, que reúne em um mesmo espaço doentes antes condenados ao isolamento. Medicina, ciência e sociedade relacionam-se, determinam as políticas de saúde e, por conseguinte, a forma como se materializam.

As instituições aqui apresentadas, algumas com diversas sedes ao longo do tempo, tiveram suas instalações total ou parcialmente preservadas, e, com base na recuperação de suas histórias e imagens, propomos um roteiro pela história da saúde no Rio de Janeiro.

Este trabalho, devido a sua dimensão, adquiriu duas formas: um livro e um CD-ROM, que vem encartado na capa. O primeiro compreende textos analíticos acerca da história da saúde no Rio de Janeiro, em que se reflete sobre distintos períodos e contextos, e é composto de cinco capítulos. A título de introdução, o primeiro capítulo, "Memória, história e patrimônio cultural da saúde: uma história possível", escrito por Gisele Sanglard e Renato da Gama-Rosa Costa, informa o leitor sobre os conceitos de história, memória e patrimônio, a relação entre eles e as ações de preservação - tanto as realizadas por iniciativa do poder público quanto as oriundas da própria sociedade. Os capítulos seguintes analisam os três grandes períodos em que o estudo foi dividido. "A saúde pública no Rio de Janeiro imperial", de Maria Rachel Fróes da Fonseca, apresenta um panorama das instituições de saúde no século XIX, remontando a suas origens coloniais; "A Primeira República e a constituição de uma rede hospitalar no Distrito Federal", por Gisele Sanglard, trata das instituições e dos edifícios construídos durante a República Velha, onde se percebe o processo de transformação pela qual passou a assistência pública na capital federal; "Política e saúde: diretrizes nacionais e assistência médica no Distrito Federal no pós-1930", por Cristina M. Oliveira Fonseca, analisa o período marcado pela ênfase na abertura de hospitais, decorrente da gestão do prefeito Pedro Ernesto, bem como a gestão de Gustavo Capanema no Ministério da Educação e Saúde (MES). E “Arquitetura e saúde no Rio de Janeiro", de Renato da Gama-Rosa Costa, traça a história da arquitetura das instituições de saúde, ao longo de todo o período analisado. Todos os capítulos são acompanhados por ilustrações. A iconografia é enriquecida por um caderno de imagens contemporâneas, em cores. Por fim, um pequeno glossário elaborado por Atiele Lopes esclarece o leitor sobre os termos gerais utilizados ao longo dos textos. 
O CD-ROM apresenta as versões para o inglês e o espanhol do conteúdo do livro e traz ainda, sob a forma de verbetes, textos informativos acerca das instituições e dos edifícios pesquisados. Os verbetes, apresentados nas três línguas, relacionam dados sobre a história, localização, características, uso atual, arquitetura dos prédios e, quando há, o registro de tombamento. Cada um é acompanhado de iconografia, para cuja pesquisa optamos por selecionar imagens do passado e do presente.

A escolha de tal período, compreendido entre 1808 e 1958, se deveu ao intuito de remetermos ao ano da vinda da Corte para a cidade do Rio de Janeiro, ao contexto de transformações que se sucederam a partir daí e, é claro, celebrar o bicentenário da chegada da família real portuguesa, que se comemora este ano. Percorrendo um período de 150 anos, fechamos com o ano de 1958. A década de 50 do último século, escolhida como marco final de nosso estudo, indica a consolidação da arquitetura hospitalar e do momento em que o arquiteto passa a assumir inteiramente os projetos de edificação dos hospitais. O hospital moderno, vertical, é uma tendência presente desde a década de 1930. Mas é, sem dúvida, na década de 1950 que os preceitos do 'modernismo' em arquitetura são transpostos para os hospitais da cidade, com a construção de exemplares marcantes para o cotidiano dos cariocas. O ano de 1958, especificamente, é considerado como referência para a arquitetura hospitalar moderna no Rio de Janeiro, com a finalização da obra do Hospital da Lagoa, de Oscar Niemeyer e Hélio Uchoa - a grande expressão de hospital da tipologia monobloco do período moderno.

Nossos agradecimentos a todos aqueles que nos abriram suas portas e seus acervos, que aqui se fazem representar especialmente pelas seguintes instituições: Maternidade de Laranjeiras, Casa de Portugal: Hospital e Maternidade, Hospital do Amparo Feminino, Sociedade Beneficente Israelita do Rio de Janeiro, Hospital Evangélico, Hospital Central da Aeronáutica, Hospital de Ipanema, Hospital-Maternidade Herculano Pinheiro, Maternidade Alexander Fleming, Hospital São Lucas, Instituto Nacional de Educação de Surdos (Ines), Serviço de Documentação da Marinha e Instituto de Hematologia Arthur Siqueira de Cavalcanti (Hemorio). Agradecemos também o inestimável auxílio de Vera Wanderley (Pro Matre), Luiz Guilherme Romano (Casa de Saúde Santa Lúcia), Olga de Fátima Barros (Beneficência Portuguesa), Everson Sofiste (Museu dos Bombeiros), Dásio Lopes Simões e Elizabeth Bittencourt Constantino (Hospital do Andaraí), Alexandre Estelito Mourão e Mello e Fladenor Belfort Leite (Casa de Portugal) e coronel Hélio Gouveia Prado (5ª Divisão de Levantamento do Exército).

Por fim, a Luiza Andréa Moraes Cardoso, da Sociedade de Promoção da Casa de Oswaldo Cruz (SPCOC), pelo empenho na captação de recursos para a elaboração da pesquisa e a edição deste livro e ao Bruno Martins, da Cobra Tecnologia, pelo apoio na gestão deste patrocínio. 


\title{
Memória, História e Patrimônio Cultural da Saúde: uma história possivel
}

\author{
Gisele Sanglard \\ Renato da Gama-Rosa Costa
}


A última década marcou um crescimento expressivo dos estudos voltados para a história da saúde, que acrescentou novos objetos e novas abordagens, como, por exemplo, o estudo dos hospitais e da arquitetura para a saúde. Na Casa de Oswaldo Cruz da Fundação Oswaldo Cruz (COC/Fiocruz), pesquisadores têm empreendido esforços para aprofundar estudos que buscam relacionar aspectos históricos com a identificação e valorização do patrimônio da saúde no Rio de Janeiro.

Pretendemos aqui evidenciar o patrimônio arquitetônico das instituições de saúde ao qual, embora integre o nosso cotidiano, não foi ainda conferido o devido reconhecimento, ou os edifícios que, por terem tido seu uso inicial alterado, perderam sua identidade e função. Assim, serão contempladas diversas categorias representativas do patrimônio da saúde no Rio de Janeiro.

O recorte cronológico que propomos leva em consideração dois marcos importantes para a história da saúde no Brasil. O primeiro é o ano de 1808, que remete à chegada da família real portuguesa e ao contexto de transformações que a esse momento se sucederam. Com a chegada da Corte, o Brasil tornouse centro administrativo do Reino e aqui se implementaram importantes medidas administrativas, econômicas e culturais, de impacto sobre o desenvolvimento da medicina no país, como a criação das primeiras instituições de ensino médico-cirúrgico, estabelecidas nas cidades de Salvador e do Rio de Janeiro. A Escola de Cirurgia, em Salvador, e a Escola Anatômica, Cirúrgica e Médica do Rio de Janeiro, criadas em 1808, destinavam-se à formação de quadros profissionais para os serviços públicos imperativos naquele momento.

O período final, a década de 1950, por sua vez, representou também um marco em termos do desenvolvimento institucional nos campos da medicina e da saúde pública no Brasil, bem como na capital da República: no campo da saúde com a criação, em 1953, do Ministério da Saúde - um pleito acalentado pelos médicos desde o início daquele século; no campo político, com a mudança, em 1960, da capital para Brasília, que traria mudanças para a cidade do Rio de Janeiro. Esse momento caracterizase pela consolidação da tipologia do bloco único de grande verticalidade na arquitetura hospitalar, e por ser aquele em que um profissional, o arquiteto, passa a assumir inteiramente o projeto de um hospital. Até os anos 40, os médicos ainda detinham controle considerável sobre o projeto e eram ainda os engenheiros, às vezes os engenheiros sanitários, os responsáveis pelos projetos. Com a arquitetura moderna, o arquiteto passa a utilizar o programa hospitalar como forma de exercitar ao máximo sua capacidade de articulação de usos complexos de conhecimento científico em uma construção civil. 
A elaboração de um projeto hospitalar sempre dependeu de uma equipe multidisciplinar composta por médicos e especialistas de diversas áreas. O arquiteto passa a ser o coordenador de todo o processo, e os projetos assumem, a partir dos anos 60, uma padronização tanto tipológica quanto na sua forma arquitetônica. Finalmente, o ano de 1958 marca a finalização da construção do Hospital da Lagoa, grande expressão do hospital vertical no Rio de Janeiro e marco da moderna arquitetura hospitalar carioca.

\section{Os Lugares da Memória, da História e do Patrimônio}

História, memória e patrimônio são conceitos aparentemente distantes, mas intimamente interligados. Desde a publicação da obra coordenada pelo historiador francês Pierre Nora, Les Lieux de Mémoire [Lugares de Memória] (1984), os estudos envolvendo memória e história passaram a conquistar historiadores por todo o mundo e, sobretudo, na França. A esse trabalho seguiram-se diversos outros em que se procura pensar a relação entre esses conceitos e aplicá-los em estudos de caso, muitos dos quais dedicados a refletir sobre a história da França e sobre a memória dos judeus sobreviventes da Shoah (Joutard, 1993; Todorov, 1995; Ricœur, 2000; Yates, 1975; Detienne, 1988; Bosi, 1987; Lowenthal, 1988; Rossi, 1991).

O trabalho de Pierre Nora não foi, entretanto, pioneiro. Entre os clássicos devem ser citadas as obras de Henri Bergson (1990) e de Maurice Halbwachs (1990) - publicados pela primeira vez, respectivamente, em 1896 e no primeiro quartel do século XX. E entre os anos de 1977 e 1982, o também historiador Jacques Le Goff, parceiro de Nora na coleção Faire de l'Histoire, publicou uma série de artigos na Enciclopédia Einaudi, reunidos pouco tempo depois, em 1986, em uma obra intitulada Histoire et Mémoire. Entre os artigos escritos por Le Goff vale ressaltar "História", "Memória" e "Documento/Monumento" - em que a memória é entendida como um conceito crucial, por constituir um reservatório vivo da história, apesar de sua mobilidade, e rico em arquivos e em documentos/monumentos, além de ser considerada como "eco sonoro (e vivo) do trabalho histórico". Documentos e monumentos são dois tipos de materiais aplicados à memória coletiva e ao que Le Goff chamou de "sua forma científica", a história. O documento é produto da sociedade que o fabricou, e somente a análise "do documento enquanto monumento permite à memória coletiva recuperá-lo e ao historiador usá-lo cientificamente" (Le Goff, 1992: 475, 535, 545). Assim, todo documento é um monumento, e todo monumento é um documento passível de análise pelo historiador.

No Brasil, ainda na década de 1980, podemos citar a publicação do n 87 (Memória e História), de 1986, da revista Tempo Brasileiro, do Colégio do Brasil, e do no 3 da revista Estudos Históricos (1989/1), publicada pelo Centro de Pesquisa e Documentação da Fundação Getulio Vargas (Cpdoc/FGV), dedicada ao tema da memória, que trouxe textos do sociólogo Michel Pollack ("Memória e esquecimento"), do antropólogo Hugo Lovissolo ("Memória e formação dos homens") e da historiadora Myriam Moraes Lins de Barros ("Memória e família"), o que evidencia a importância desta discussão no meio acadêmico brasileiro. ${ }^{1}$ Vale chamar a atenção para os trabalhos do historiador Ulpiano Bezerra de Menezes (1999) sobre memória, história e patrimônio, e sua preocupação com o valor que se atribui ao patrimônio. Para ele, "a orientação e eficácia do trabalho com o patrimônio cultural dependem, visceralmente, de nosso projeto de sociedade, do tipo de relações que desejamos instaurar entre os homens" (1992: 194). 
Pierre Nora (1984) chama atenção para o fato de que os conceitos de memória e história são opostos. A memória - a deusa Mnemosine -, feita de partes iguais de lembrança e esquecimento, é viva, está em constante mutação e é suscetível a manipulações; já a história - a musa Clio, filha de Mnemosine - é a reconstrução imperfeita daquilo que não existe mais. Ou dito de outra forma: a memória está enraizada no concreto, no tangível - em um espaço determinado, em um gesto ou em um objeto, no absoluto -, enquanto que a história está ligada às continuidades temporais, na evolução e na relação entre as coisas, trabalhando na relativização (Nora, 1984: XIX). E Le Goff ressalta que o 'tempo', categoria fundamental para os estudos históricos, inscreve a memória na história. Memória é também, e, sobretudo, "um elemento essencial do que se costuma chamar identidade, individual ou coletiva, cuja busca é uma das atividades fundamentais dos indivíduos e das sociedades de hoje" (Le Goff, 1992: 476).

Portanto, falar em memória é falar em identidade de grupo, e os 'lugares de memória' seriam os espaços onde esta se cristaliza e se refugia. Podem ser arquivos, estátuas, cemitérios, dicionários e qualquer outro lugar. A necessidade de recorrer a esses 'lugares' se dá por não existirem mais os 'meios' pelos quais a memória é transmitida, a tradição oral. Para Walter Benjamin (1993), o fim do narrador como figurachave na transmissão da memória decorre da perda da experiência coletiva e do advento da individualidade, típica de seu tempo. Pierre Nora (1997) ressalta que, no caso particular da França, o culto à memória está vinculado ao processo de unificação da Europa, e tal movimento seria, então, entendido como reflexo da crise de identidade pela qual a França passou no fim do século passado. A destruição das identidades tradicionais, acrescida da necessidade de uma identidade coletiva, foi, em parte, um dos responsáveis pelo culto à memória. Todorov (1995) acrescenta que somente ao se constituir um passado comum é que se poderá conseguir o reconhecimento do grupo.

Uma das conseqüências desse movimento é a febre de comemorações: as datas nacionais, as grandes efemérides, ou mesmo eventos que interliguem um grupo menor. As próprias celebrações se transformaram em objeto de análise, em 'lugares de memória', como forma de controle do fenômeno, mas que acabou sendo absorvido pela "bulimia comemorativa", como Paul Ricœur (2000) definiu a febre das comemorações que varreu primeiro a França, mas depois atingiu outros países.

Essa febre abriu caminho para um outro fenômeno, totalmente vinculado ao culto à memória: a promoção do patrimônio e sua cristalização no 'monumento histórico'. Por patrimônio entendemos o conjunto de lendas, memórias, a língua e mesmo particularidades vitais da natureza, ou seja, certas condições fundamentais da existência nacional (Chastel, 1997), que pressupõem sempre a noção de continuidade e uma função de alimentação da identidade cultural (Menezes, 2006). Os monumentos, por sua vez, podem ser divididos em três classes distintas: intencionais, por terem sido criados visando à comemoração de um momento específico; históricos, aos quais foi atribuído este valor, por questões subjetivas; e antigos, aqueles que sobreviveram à ação do tempo. É justamente essa atribuição do valor histórico a uma categoria artística, sobretudo quando ligada aos interesses nacionais e patrióticos, que protege o monumento. Ou, como diz Dominique Poulot (1997) citando A. Riegl, a proteção só se efetiva quando toda a população considera as obras de seus antepassados como parte de sua própria atividade criativa. Assim, patrimônio se situa entre a memória e a história (Le Goff, 1997), e

a memória deu ao patrimônio seu sopro, sua dinâmica e seu élan. Mas seu trabalho emancipador está terminado. A problemática do patrimônio está agora solidamente instalada no coração das sociedades 
contemporâneas. Seu ritmo de crescimento, seu enraizamento na longa duração, suas justificativas profundas e seu futuro, é no entanto a história, e somente a história, que pode e deve lhe dar: pela escolha que ela dita, pelas hierarquias que ela sugere ou impõe, pela escala de valores que ela comporta, pela disciplina que ela representa. (Nora, 1997: 397, grifo nosso, tradução livre)

Cabe à história estudá-lo e assim possibilitar seu conhecimento, no tempo. Os conceitos de história, memória e patrimônio estão umbilicalmente interligados, diríamos mesmo que são indissociáveis. É por meio dos estudos históricos que poderá haver uma consciência sobre a importância do patrimônio e em seguida uma ação de preservação - é somente por meio do conhecimento que pode ser construída a sua defesa. Assim, o patrimônio deve ser objeto de um saber, que ele deve suscitar. Para Jacques Le Goff (1997), é um dever transformar o patrimônio em objeto de saber, e para Ulpiano Bezerra de Menezes, "os testemunhos de diversa natureza sobre tempos passados devem ser considerados suportes de informação sobre a mudança, seus processos, seu alcance. Por isso devemos não só considerá-los enquanto produtos, mas investigar também os contextos de produção e consumo" (Menezes, 2006: 186).

A França se torna, nesse aspecto, um exemplo no que tange às ações e às políticas de preservação do patrimônio nacional - seja ele arquitetônico, museológico, artístico ou arquivístico. Não à toa, museus, arquivos, bibliotecas, medalhas, moedas, cemitérios, cenotáfios, festas nacionais, monumentos históricos, símbolos nacionais são considerados como 'lugares de memória' para os franceses. O patrimônio da saúde também entra no rol desses 'lugares' especiais: o Hôtel-Dieu de Beaune (Bourgogne), transformado em museu que recria o cenário do final do século XV, quando foi construído; o Musée de l'Assistance Publique-Hôpitaux de Paris, que guarda um grande acervo museográfico, formado a partir do patrimônio dos hospitais parisienses; ${ }^{2}$ ou os Archives de l'Assistance Publique-Hôpitaux de Paris. ${ }^{3}$

No campo da preservação de bens imóveis, vale chamar atenção para o movimento de salvaguarda dos sanatórios franceses, construídos no entre-guerras para o combate à tuberculose. A inserção desses edifícios no rol de monumentos esbarra em dificuldades que envolvem a memória coletiva de diversos atores, na medida em que a tuberculose foi o grande flagelo da sociedade francesa da virada do século XIX para o século XX, tendo perdurado até o final da $1^{\mathrm{a}}$ Grande Guerra. Esses edifícios se tornaram, para grande parte das famílias francesas, um emblema de uma época passada, ainda muito vívida, na qual um parente ou um amigo era internado em um sistema de quase concentração, no espaço da morte. No imaginário médico, a eles subjaz a idéia de uma ilusão, ou de um fracasso terapêutico, na medida em que esses 'hotéis-hospitais' não levavam à cura total, só alcançada com a descoberta dos antibióticos. Para aqueles que querem aproveitar suas instalações, dando-lhes outro uso, esses sanatórios, construídos para isolamento e em grandes proporções, apresentam dificuldade de inserção na dinâmica econômica da cidade, o que se revela um entrave para investimentos do setor público e privado (Cremnitzer, 2005). Transformar essa lembrança negativa, ou ao menos incômoda, em fato positivo, permitindo que esses edifícios se tornem 'lugares de memória' da medicina e da saúde, é um movimento que arquitetos, médicos e estudiosos do patrimônio têm levado a cabo na França.

\section{A Questão do Patrimônio na América Latina e no Brasil}

Segundo Françoise Choay (2001), a noção de monumento histórico e as práticas de conservação estiveram restritas à Europa até finais do século XIX e primeiras décadas do século XX. As conferências 
internacionais para a Conservação dos Monumentos Históricos, realizada em Atenas em 1931 e em Veneza em 1964, embora contassem com a participação maciça de europeus, segundo observou Choay, certamente foram importantes para difundir os conceitos nelas discutidos pelo restante do mundo. Para Funari e Pelegrini (2006), a ênfase no patrimônio nacional observada em âmbito mundial se deu entre as duas grandes guerras, devido às perdas ocasionadas pelos conflitos, refletindo-se no resto do mundo. No caso brasileiro, outros fatores foram considerados, como veremos mais adiante.

A construção do patrimônio e das ações de preservação mundial atuaria em três frentes: no entendimento quanto ao seu valor como monumento e símbolo, na compreensão do que considerar patrimônio e na criação de organismos e instituições que tenham a preservação como missão. Na base dessas ações estão a discussão e a escolha do que pode ser considerado patrimônio e sobre como atuar para a sua preservação e salvaguarda para as gerações futuras.

A realização do sétimo encontro dos Entretiens du Patrimoine - seminário organizado pela Diretoria do Patrimônio da França - em 1998, em comemoração aos 30 anos da publicação do Inventário Nacional do Patrimônio daquele país, confirma a pertinência dessas discussões ainda nos dias de hoje. O seminário, que recebeu o subtítulo "Ciência e consciência do patrimônio", contou com a presença de historiadores, geógrafos, arquitetos, conservadores, entre outros profissionais engajados na discussão sobre o patrimônio, além de políticos. A direção dos trabalhos, a cargo de Pierre Nora, também evidencia a estreita ligação entre a história e o patrimônio ou, como afirmou Maurice Agulhon (1997), para justificar sua presença no seminário: todo objeto datado está em relação com o tempo e tudo o que tem relação com o tempo é de interesse do historiador. Logo, objetos de arte e afins são de interesse do historiador.

A noção de patrimônio, longamente construída na Europa desde a Revolução Francesa, instaurou-se no Brasil vinculada às ações do Estado Novo e ao moderno conceito de patrimônio, segundo o qual este deveria ser entendido "não mais no âmbito privado ou religioso das tradições antigas e medievais, mas [naquele] de todo um povo, com uma única língua, origem e território" (Funari \& Pelegrini, 2006: 17). Essa afirmação, direcionada pelos autores ao exemplo italiano, pode muito bem se inserir no contexto do primeiro governo Vargas (1930-1945) e sua política de formação do Estado brasileiro, associada à construção de uma identidade nacional. Essa temática estava presente no Brasil desde a década de 1920, envolvendo as artes e a constituição de uma estética nacional calcada na releitura das origens coloniais. Nos anos 30, essa identidade nacional ganharia contornos mais nítidos, em busca de uma estética que olhasse para frente, ao mesmo tempo que tentava manter um diálogo com o passado.

Ao falarmos em identidade e nacionalidade, estamos trabalhando com noções e conceitos construídos ao longo dos tempos e que no Brasil assumiram características contraditórias no debate sobre origem, passado, tradição e futuro. Quando se fala de patrimônio brasileiro, é preciso estar consciente de que este não se constituiu naturalmente, ou seja, foi construído, pactuado e compartilhado por instituições, intelectuais e técnicos participantes dos debates em torno da 'memória nacional'. Somente na década de 1930 é que a questão da memória foi tomando corpo no Brasil. Maria Cecília Londres Fonseca (2005) indica o ano de 1934 como marco inicial desse processo. Foi quando se definiu, constitucionalmente, como competência da União e dos estados a proteção das belezas naturais e dos monumentos de valor histórico ou artístico. Não por acaso, nesse mesmo ano a cidade colonial de Ouro Preto (MG) foi declarada monumento nacional. 
A autora sublinha duas peculiaridades na constituição, no Brasil, de um órgão especificamente voltado para a preservação do patrimônio histórico e artístico nacional. Primeiro, enquanto os países europeus contemplavam tipos de bens isolados, no Brasil se atuava de forma mais "abrangente e articulada", propondo-se "uma única instituição para proteger todo o universo de bens culturais" (Fonseca, 2005: 97). Em segundo lugar, o engajamento de intelectuais no projeto indicava uma postura claramente mais inovadora, sobretudo no uso do conceito de monumento histórico e no processo de escolha dos objetos do passado a serem objeto de salvaguarda, conforme indicação da Carta de Atenas, de $1933 .{ }^{4}$

O Ministério da Educação e Saúde, constituído em 1934, tomaria para si a tarefa de criar esse órgão, implementando o Serviço de Patrimônio Histórico, Artístico e Nacional (Sphan) e vinculando-o a uma compreensão maior sobre patrimônio e memória, agregando-os à noção de arte e cultura. Uma cultura que se expressava como síntese das três frentes de atuação do ministério: educação popular, saúde pública e assistência social. Para Gustavo Capanema, ministro da Educação e Saúde (1934-1945), essas ações teriam uma única finalidade, a formação da "cultura do homem brasileiro" (Amora, 2006: 17).

A noção de cultura acabaria por prevalecer, e o Sphan passaria, nos anos 1980, a responder administrativamente ao Ministério da Cultura. Segundo Maria Cecília Londres Fonseca, entre o fim dos anos 1970 e o início dos anos 1980, o ministério optou por priorizar não apenas as necessidades culturais dos grupos excluídos dos benefícios da política cultural implementada até então, mas igualmente suas necessidades econômicas e sociais. Mais que isso: "era preciso que essas comunidades passassem a participar do processo de construção e de gerenciamento da produção cultural brasileira, inclusive do patrimônio cultural" (Fonseca, 2005: 158).

De fato, como atributo essencial do exercício da cidadania e da responsabilidade do Estado, aquela década assistiu a iniciativas em prol da recuperação da memória, da valorização e do direito à informação. Mais especificamente no Brasil, a "febre da memória" a que se referem as reflexões propostas pelo grupo de Nora e Le Goff atingia os arquivos e a documentação histórica. Estes, de certo modo, beneficiaram-se de tal febre, que não apenas entrava em cena como tema de estudo entre especialistas, mas se revelava naquele contexto - como suporte dos processos de construção da identidade nacional, de reivindicações de grupos e da expressão de anseios de segmentos sociais diversos que retornavam com vigor às arenas do processo político. Situação semelhante podemos identificar em outros países da região das Américas, em um contexto de recuperação, consolidação e ampliação das condições de livre expressão e de participação social.

O documento apresentado pelo grupo de trabalho História e Patrimônio Cultural da Saúde, reunido durante a $4^{\mathrm{a}}$ Reunião de Coordenação Regional da Biblioteca Virtual de Saúde (BVS), no $7^{\circ}$ Congresso Regional de Informação em Ciências da Saúde (Crics), realizado em 2005 em Salvador, que pode ser entendido como um marco na discussão sobre história, memória e patrimônio da saúde no Brasil, considerou "o Patrimônio Cultural da Saúde como um conjunto de bens materiais e simbólicos socialmente construídos, que expressam o processo da saúde individual e coletiva nas suas dimensões científica, histórica e cultural". ${ }^{5}$ Ao trabalharmos com o patrimônio cultural da saúde, estaremos em primeiro lugar definindo um conceito abrangente e que permite acompanhar as transformações pelas quais a saúde passou desde o início da colonização portuguesa. A saúde não é um dado, mas uma construção histórico-social cujas definições, significados culturais e arranjos políticos são variáveis no 
tempo. Essa diversidade é o que se pretende identificar e inventariar. Assim, estamos inscrevendo este trabalho na fórmula proposta por Pierre Nora e Jacques Le Goff, segundo a qual o patrimônio está localizado entre a memória e a história e cabe a esta última analisá-lo.

Ensaios de salvaguarda do patrimônio da saúde vêm surgindo no plano internacional nos últimos anos, ligados diretamente ao valor simbólico a ele conferido pelas comunidades nas quais está inserido. Exemplos na Holanda, na Índia, Inglaterra e França ${ }^{6}$ se somam ao caso da experiência pioneira do Chile. Originada na mobilização da população e de seus funcionários contra a demolição do antigo Hospital San Jose, essa experiência possibilitou seu tombamento pelo Ministério de Educação chileno e, mais que isso, ensejou a criação da Unidade de Patrimônio Cultural da Saúde, vinculada ao Ministério da Saúde, o que serviu de inspiração para a constituição da rede latino-americana na qual nos inscrevemos desde 2005.

Esse movimento é concomitante com uma nova leitura que a historiografia ibero-americano faz dos 'hospitais', que vão deixando de ser estudados apenas como espaço da prática médica, para serem problematizados na análise histórica - inseridos no contexto da história da saúde e na história social. O espaço que o estudo dos hospitais vem ocupando pode ser dimensionado nos congressos acadêmicos, como as Jornadas Peruanas de Historia de la Ciencia, la Tecnología y la Salud - Medicina Social e Inclusión Social en Perspectiva Histórica, ocorrido em setembro de 2007, em Lima, Peru. Nesse seminário houve uma mesa dedicada ao tema "Hospitales en perspectiva histórica", que contou com a participação do peruano Antonio Coello, do norte-americano Brian Bauer, que apresentaram a comunicação "Evidencias arqueológicas del Hospital de San Andrés", e da mexicana María Rosa Gudiño, que apresentou "Hospitales y pintura mural: salud y modernización en México, 1944-1958".

Na Europa, em seminários como Bispos, Cabidos e Assistência na Península Ibérica (séculos XVIXVIII), realizado pela Universidade de Évora, Portugal, o qual resultou em um livro organizado por Laurinda Abreu (2004), procura-se refletir sobre o papel do hospital naquelas sociedades. Nesse seminário, em específico, os temas da assistência, da Igreja e do poder secular foram debatidos por historiadores brasileiros, portugueses e espanhóis - com ênfase na ação das Misericórdias e na ligação dos hospitais com a Igreja no período moderno, entre outros temas correlatos. O mesmo pode ser dito da sessão temática "Assistência e caridade como estratégias de intervenção social: Igreja, Estado e comunidade (Península Ibérica, séculos XV-XX)", realizada no XXV Encontro da Associação Portuguesa de História Econômica e Social, em 2005, também em Évora. Desse segundo evento resultou o livro, organizado por Laurinda Abreu (2007), homônimo da sessão temática que o originou. Contando com a participação de historiadores portugueses e espanhóis, o livro permite traçar um panorama do hospital na Península Ibérica, na longa duração.

A abertura de museus dedicados à saúde, dentro de universidades e de hospitais, em diversos países da América Latina - fortemente marcados pela diversidade cultural -, parece indicar uma direção que nos faz reviver a 'febre da memória' da década de 1980, só que desta vez incluindo o patrimônio da saúde, criando espaços de reflexão, de difusão e de ensino. Os casos mais notáveis são os da Faculdade de Ciências Médicas da Universidade Nacional de Córdoba e dos museus dedicados a hospitais na Argentina, como o Museu Histórico Hospital B. Rivadavia, que promove encontros sobre o patrimônio cultural dos hospitais, em parceria com a Comissão de Preservação do Patrimônio Histórico Cultural do Ministério da Cultura argentino. ${ }^{7}$ 
No Brasil, ainda são tímidos os estudos baseados na historicidade dos hospitais, bem como as ações de preservação das edificações ligadas a tais temáticas, como as de algumas Santas Casas de Misericórdia. Podemos citar o pioneirismo do Museu Emílio Ribas, da Secretaria de Saúde do Estado de São Paulo, instalado onde funcionou o antigo Desinfectório do Estado, ou mesmo o Museu de História da Medicina do Rio Grande do Sul, instalado nas dependências da Beneficência Portuguesa de Porto Alegre, inaugurado em 2007, em parceria com o Sindicato Médico do Rio Grande do Sul. Um caso notável é o da Fundação Oswaldo Cruz no Rio de Janeiro, na qual um conjunto de prédios construídos no início do século XX para laboratórios de pesquisa, ensino e produção em saúde foi tombado pelo Instituto do Patrimônio Histórico e Artístico Nacional (Iphan) e desde então recebe investimentos contínuos para a sua preservação. Todavia, não há nenhum instrumento organizado, com informações sistematizadas, que permita tanto ao estudioso quanto ao leigo recuperar a história da saúde no país por meio de seus monumentos.

Nosso objetivo ao dar continuidade a estas discussões é contribuir para as ações de preservação dos organismos responsáveis nos três níveis de atuação - federal, estadual e municipal. Que as informações obtidas subsidiem novos processos de inscrição em livros de tombos, incrementando os (poucos) objetos de saúde já registrados, e que estes possam ser valorizados sob uma ótica cultural mais abrangente, que os associe à história da saúde e de suas instituições e acervos.

Finalmente, pretendemos revelar os profissionais que atuaram nos projetos arquitetônicos, entre arquitetos, engenheiros e construtores, numa tentativa de recuperar a memória de sua atuação, muitas das vezes esquecida pela historiografia da arquitetura brasileira. Insistimos que tal historiografia não tem privilegiado a investigação sobre os programas hospitalares, e quando o faz procura se concentrar na atuação individual dos profissionais mais renomados, negligenciando, a partir de um certo momento, a estrutura político-administrativa que permitiu a construção em massa de edifícios públicos por todo o Brasil, sobretudo depois dos anos 1930 e especialmente durante o primeiro governo Vargas.

Queremos tornar pública essa valiosa fonte de informação para a história da saúde e das ciências biomédicas no Brasil, a qual, agregada à identificação de seus acervos arquivísticos, bibliográficos e museológicos, poderá criar novas possibilidades de investigação e de geração de conhecimento.

O acervo recebido dos antepassados ajuda a conhecer a nossa história e evidencia os valores que caracterizam o grupo ao qual pertencemos. O desaparecimento dos referenciais mais significativos de um grupo ou de um espaço, tais como marcos arquitetônicos, paisagens e manifestações culturais, faz com que o indivíduo perca a identificação com o meio onde habita e com a sua própria história.

\section{Notas}

${ }^{1}$ A organização do fórum internacional Mémoire et Histoire ocorrido em maio de 1998, na Unesco e na Sorbonne, é outro exemplo de como o tema das relações entre memória e história passou a ser crucial para a historiografia. E como disse Elie Wiesel no prefácio da publicação do evento, "Lembrar é permitir ao homem afirmar que o tempo deixou traços e cicatrizes na superfície da história, que todos os acontecimentos são interligados uns aos outros, como os seres. Sem a memória, nada é possível, nada pode ser empreendido" (Pourquoi se Souvenir?, 1999: 10-11, tradução livre). 0 fórum foi organizado pela Académie Universelle de Culture, criada por Elie Wiesel em 1992, em Paris, com o objetivo de promover reflexões sobre o século XXI.

2 Entre esses objetos pode-se citar a veste sacerdotal de São Vicente de Paulo, a roda dos expostos, a coleção de mamadeiras, os potes da farmácia. 
${ }^{3}$ A instituição guarda os arquivos administrativos dos hospitais e da própria Assistance Publique, desde o século XIII (registros de entrada e saída, nascimento e morte etc.); arquivos médicos (prontuários etc.); iconográficos (fotografias, plantas, pranchas anatômicas etc.) e biblioteca contendo livros desde o século XVI e periódicos.

${ }^{4} \mathrm{Na}$ Carta de Atenas, afirma-se que os testemunhos do passado devem passar por uma seleção - “Nem tudo que é passado tem, por definição, direito à perenidade; convém escolher com sabedoria o que deve ser respeitado" -, o que justificava em grande medida a participação dos intelectuais (Carta de Atenas, 1933: 25-26).

${ }^{5}$ História e Patrimônio Cultural da Saúde. Termo de constituição da Rede Latino-Americana de História e Patrimônio Cultural da Saúde, 2005: 4-6. Esse documento foi originalmente elaborado e apresentado como termo de referência pelo Ministério da Saúde do Brasil/ Casa de Oswaldo Cruz/Fiocruz e Ministério da Saúde do Chile/Unidade do Patrimônio Cultural da Saúde, para orientar as discussões do grupo de trabalho História e Patrimônio Cultural da Saúde, que se reuniu no evento citado. 0 texto foi publicado em espanhol para os Anais Chilenos de Historia da Medicina, 16: 237-242, 2006, como "Historia y patrimonio cultural de salud: propuesta para la creación de uma biblioteca virtual latinoamericana".

${ }^{6}$ A França, que já conta com um grande inventário de seus espaços de cura, vem sublinhando a dificuldade de se agregar valor patrimonial aos sanatórios construídos no entre-guerras. Uma das ações pontuais, desencadeada por arquitetos e historiadores da arte, seria reparar a ausência desses edifícios das listas de obras de arte do movimento moderno e, assim, iniciar um processo de recuperação e valorização desse acervo (Cremnitzer, 2005). Na Índia, também se luta para se preservar o último sanatório do tipo solário remanescente no mundo. Na Inglaterra, o sanatório para tuberculosos de Sully Glamorgan está sendo restaurado para uso residencial, com vistas à sua recuperação. Finalmente, vale recordar que, na Holanda, a eminência da destruição do sanatório de Zonnestraal ensejou a criação do Docomomo (International Comitte for Documentation and Conservation of Sites, Buildings and Neighbourhood of Modern Mouvement) em 1988, e chamou a atenção mundial para o quanto as edificações associadas ao movimento moderno em geral vêm sofrendo com a desvalorização e com os efeitos da ação do tempo, da decadência e de usos impróprios.

${ }^{7}$ No segundo evento, realizado em maio de 2007, o Brasil esteve representado pelas ações realizadas pela COC/Fiocruz.

Referências

ABREU, L. (Ed.) Igreja, Caridade e Assistência na Península Ibérica (sécs. XVI-XVIII). Évora: Edições Colibri, Cidehus/Universidade de Évora, 2004.

ABREU, L. (Ed.) Asistencia y Caridad como Estrategias de Invervención Social: Iglesia, Estado y comunidad (s. XVXX). Bilbao: Universidad del País Vasco, 2007.

AGULHON, M. L'historien et la rencontre de l'objet: l'exemple de la République en sculpture. In: NORA, P. Science et Conscience du Patrimoine: actes des Entretiens du Patrimoine. Paris: Fayard, Éditions du Patrimoine, 1997.

AMORA, A. O Nacional e o Moderno: arquitetura e saúde no Estado Novo nas cidades catarinenses, 2006. Tese de Doutorado, Rio de Janeiro: Programa de Pós-Graduação do Instituto de Pesquisa e Planejamento Urbano e Regional da Universidade Federal do Rio de Janeiro (Ippur/UFRJ).

BENJAMIN, W. O narrador. In: BENJAMIN, W. Obras Escolhidas: magia e técnica, arte e política. 5. ed. São Paulo: Brasiliense, 1993.

BERGSON, H. Memória e Matéria. São Paulo: Martins Fontes, 1990.

BOSI, E. Memória e Sociedade: lembranças de velhos. São Paulo: T. A. Queiroz, Edusp, 1987.

CHASTEL, A. La notion de patrimoine. In: NORA, P. Les Lieux de Mémoire. 3 v. La République, La Nation, Les Frances. Paris: Quarto, Gallimard, 1997.

CREMNITZER, J-B. Architecture et Santé: les temps du sanatorium en France et Europe. Paris: Éditions A. et J. Picard, 2005.

CHOAY, F. A Alegoria do Patrimônio. São Paulo: Estação Liberdade, Editora da Unesp, 2001.

DETIENNE, M. Os Mestres da Verdade na Grécia Arcaica. Rio de Janeiro: Jorge Zahar, 1988.

FONSECA, M. C. L. O Patrimônio em Processo: trajetória da política federal de preservação no Brasil. 2. ed. Rio de Janeiro: Editora UFRJ, Iphan, 2005. 
FUNARI, P. \& PELEGRINI, S. Patrimônio Histórico e Cultural. Rio de Janeiro: Jorge Zahar, 2006.

HALBWACHS, M. A Memória Coletiva. São Paulo: Vértice, 1990.

História e Patrimônio Cultural da Saúde. Termo de constituição da Rede Latino-Americana de História e Patrimônio Cultural da Saúde. Termo de Referência. Ministério da Saúde do Brasil/Casa de Oswaldo Cruz/Fiocruz e Ministério da Saúde do Chile/Unidade do Patrimônio Cultural da Saúde.

Historia y patrimonio cultural de salud: propuesta para la creación de uma biblioteca virtual latinoamericana. Anais Chilenos de Historia da Medicina, 16: 237-242, 2006.

JOUTARD, P. Mémoire, une passion française: l'histoire. In: BURGUIÈRE, A. \& REVEL, J. Histoire de la France: choix culturels et mémoire. Paris: Seuil, 1993.

LE GOFF, J. Reflexões sobre a História. Lisboa: Edições 70, 1982.

LE GOFF, J. História e Memória. São Paulo: Editora da Unicamp, 1992.

LE GOFF, J. Conclusion de la journée du 28 novembre. In: NORA, P. Science et Conscience du Patrimoine: actes des Entretiens du Patrimoine. Paris: Fayard, Éditions du Patrimoine, 1997.

LOWENTHAL, D. The Past is a Foreign Country. Cambridge: Cambridge University Press, 1988.

MENEZES, U. B. de. O patrimônio cultural entre o público e o privado. In: Direito à Memória: patrimônio histórico e cidadania. São Paulo: Departamento do Patrimônio Histórico, 1992.

MENEZES, U. B. de. A crise da memória, história e documento: reflexões para um tempo de transformações. In: SILVA, Z. (Org.) Arquivos, Patrimônio e Memória: trajetórias e perspectivas. São Paulo: Editora da Unesp, 1999.

MENEZES, U. B. de. Identidade coletiva e arqueologia. In: BOSI, A. Cultura Brasileira: temas e situações. 4. ed. Rio de Janeiro: Ática, 2006.

NORA, P. Les Lieux de Mémoire. Paris: Gallimard, 1984. v. 1 - La République.

NORA, P. Science et Conscience du Patrimoine: actes des Entretiens du Patrimoine. Paris: Fayard, Éditions du Patrimoine, 1997.

POULOT, D. Alexandre Lenoir et les musées des Monuments français. In: NORA, P. Les Lieux de Mémoire République, La Nation, Les Frances. Paris: Quarto, Gallimard, 1997.

POURQUOI se Souvenir? Paris: Grasset, 1999.

RICCEUR, P. La Mémoire, l'Histoire et l'Oubli. Paris: Seuil, 2000.

ROSSI, P. Il Passato, la Memoria, l'Oblio. Bologna: Il Mulino, 1991.

TODOROV, T. Les Abus de la Mémoire. Paris: Arléa, 1995.

YATES, F. L'Art de la Mémoire. Paris: Gallimard, 1975. 


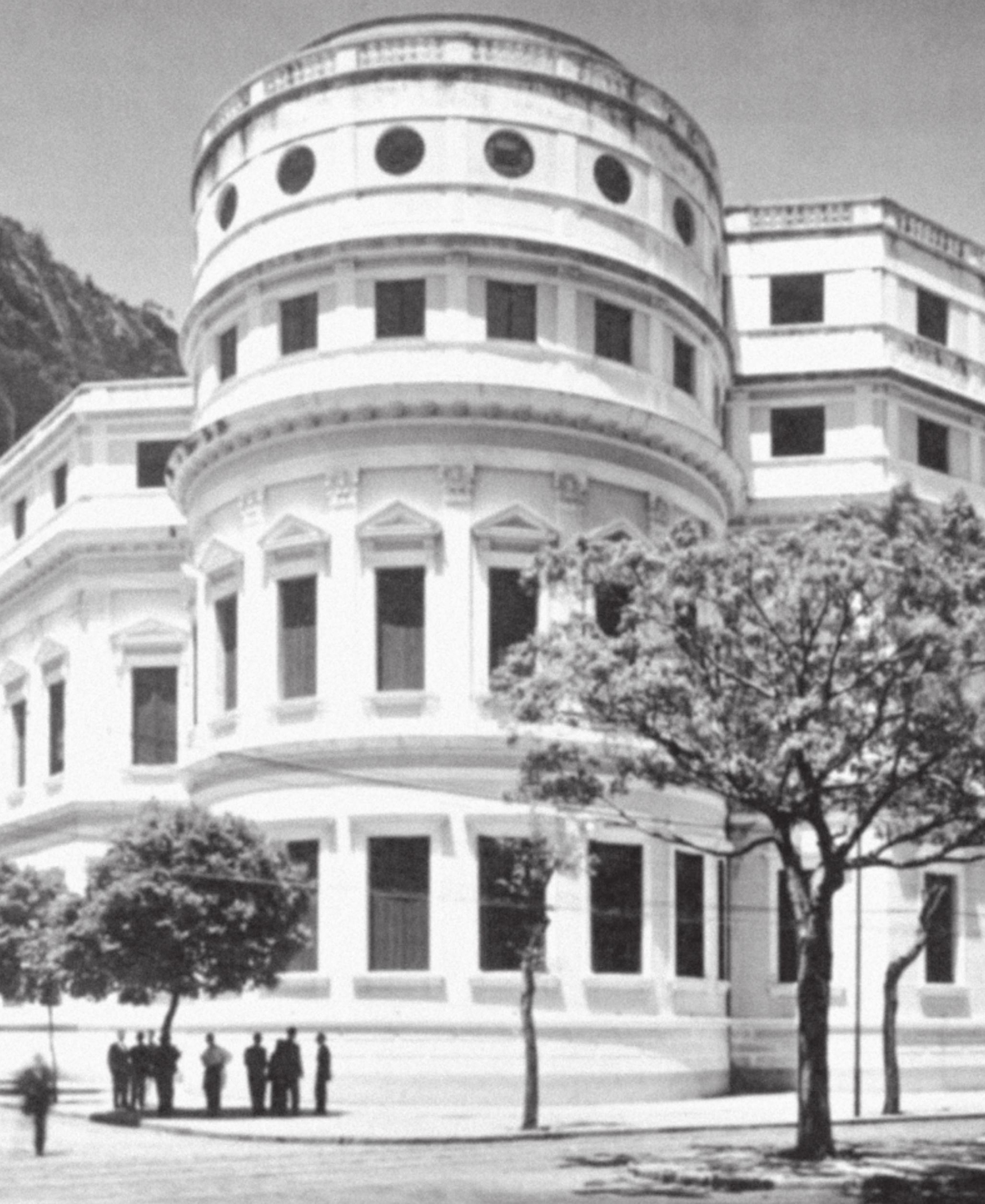




\section{2 \\ A Saúde Pública no Rio de Janeiro Imperial}

Maria Rachel Fróes da Fonseca 


\section{A Higiene e a Defesa da Saúde na Cidade Colonial}

No período colonial, coube principalmente às câmaras municipais a determinação e adoção de medidas de higiene e de defesa da saúde em cidades, como o Rio de Janeiro. Até a criação, em 1782, da Junta de Protomedicato, os comissários do físico-mor e do cirurgião-mor deveriam fiscalizar o cumprimento de tais medidas, abrangendo também a fiscalização do exercício profissional (da medicina e da farmácia) e o comércio de drogas. Até princípios do século XIX os físicos ou licenciados, os cirurgiões-barbeiros, os cirurgiões-aprovados e os cirurgiões-examinados é que praticavam a medicina no Brasil. Integravam, ainda, o mundo das artes de curar os sangradores, os curandeiros e as parteiras, para os quais a Fisicatura-Mor emitia licenças. Havia uma hierarquia entre todas essas categorias, como destaca Tânia Salgado Pimenta (2004: 68), na qual "os médicos ocupariam as posições mais prestigiadas e parteiras e sangradores, por exemplo, as mais subalternas".

Os boticários, igualmente considerados como detentores de uma arte secundária, recorreram aos saberes médicos locais, de origem indígena e africana, na constituição das farmacopéias, como assinalou Vera Regina Beltrão Marques (1999). As práticas médicas no século XVIII foram, fundamentalmente, o resultado de experiências entabuladas por europeus, africanos e indígenas (Ribeiro, 1997).

As principais orientações com relação à saúde pública seguiam normas da metrópole portuguesa e eram executadas na colônia pelos citados comissários. Os regimentos que determinaram a criação dos comissários do físico-mor e do cirurgião-mor datam, respectivamente, de 1476 e 1448.

Entretanto essas determinações não foram adotadas amplamente nos primeiros séculos de colonização, tendo persistido a existência de locais sem comissários para fiscalizar a aplicação das medidas. No final do século XVIII, contudo, começaram a vigorar em mais cidades. As competências atribuídas a esses funcionários coloniais eram: inspeção das boticas, vistoria dos hospitais, fiscalização da prática médica, determinação de medidas de caráter sanitário, exame de candidatos ao exercício profissional (barbeiro, cirurgião-barbeiro, sangrador, parteira, aprendiz de boticário) e a cassação de diplomas e demais licenças. Entre as medidas de cunho sanitário, havia a determinação de que os habitantes mantivessem limpos seus quintais e as ruas, eliminando o lixo e demais dejetos.

Outras medidas de caráter mais imediato eram adotadas pelos capitães-generais e pelos governadores das capitanias, aos quais estavam subordinados os provedores de saúde dos portos e os guardas-da-saúde dos portos. Para o combate às epidemias, determinava-se a prática do isolamento dos contagiosos e a 
instalação de hospitais militares e de santas casas. Esses provedores e guardas-de-saúde dos portos promoviam o policiamento sanitário, fiscalizando a entrada de navios, por meio das chamadas "visitas da saúde", e o desembarque de pessoas contaminadas.

Com a criação da Junta do Protomedicato, no final do século XVIII, buscou-se reestruturar as diversas funções relativas à assistência sanitária nas colônias. As funções até então atribuídas ao físico-mor e ao cirurgião-mor passaram a ser de responsabilidade dessa junta, a qual era composta de sete deputados (sendo físicos e cirurgiões), dois secretários e um porteiro. Sua atuação abrangerá o referendo dos diplomas daqueles formados em escolas estrangeiras, tendo em vista a inexistência de escolas médicas no Brasil. Entretanto, a existência do Protomedicato foi relativamente curta, e em 1809 foram restabelecidos os cargos de físico-mor e de cirurgião-mor.

A regularização da saúde pública voltou, então, a estar sujeita à atuação do físico-mor e do cirurgiãomor, aos quais cabia a nomeação dos delegados que fiscalizariam a saúde pública nas províncias. Ainda eram suas atribuições a determinação de medidas sanitárias locais, como a limpeza dos terrenos e das ruas, e a regulamentação do consumo de certos produtos (notadamente as bebidas alcoólicas).

Os diversos regulamentos sanitários que se sucederam no contexto colonial mostraram-se ineficientes, constituindo-se apenas em medidas de higiene, e não propriamente em uma política de saúde pública.

Desde o período colonial a assistência médico-hospitalar realizava-se, fundamentalmente, em dependências das santas casas da Misericórdia, como o Hospital da Santa Casa da Misericórdia do Rio de Janeiro, nos hospitais das ordens terceiras dos Mínimos de São Francisco de Paula, de Nossa Senhora do Monte do Carmo e de São Francisco da Penitência. O Hospital da Santa Casa da Misericórdia do Rio de Janeiro serviu de centro de atendimento hospitalar militar por um longo período, e em 1763 o vicerei D. Antônio Alvares da Cunha (conde da Cunha), visando a resolver a situação do atendimento médico militar, instalou uma enfermaria no Quartel das Guarnições das Naus, na encosta do morro de São Bento. Essa enfermaria foi transferida, posteriormente, daquele quartel para o edifício do antigo Colégio dos Jesuítas, situado no morro do Castelo, dando origem, em 1769, ao Hospital Real Militar e Ultramar, o primeiro hospital militar fundado no Rio de Janeiro.

A avaliação do estado precário da saúde no país e da ineficácia dos meios até então empregados era compartilhada por muitos estudiosos, e às vezes encaminhada aos órgãos oficiais/ou representantes, objetivando a solução de tais deficiências. É bastante ilustrativa a correspondência enviada a José Luis de Castro, vice-rei e conde de Resende, pelo botânico Manuel Joaquim de Sousa Ferraz, em 1795:

Sendo o cuidado da saúde pública a primeira lei do Estado social; e vendo eu que desgraçadamente são inertes e insuficientes os meios que empenha a este fim a arte saudável, no fértil e aprasível continente do Brasil, servindo-se de drogas velhas, corruptas e adulteradas, que por grande preço se mandam vir da Europa, podendo-se aliás fazer uso com indisível proveito e vantagens das maravilhosas e mui virtuosas plantas de que a benigna providência enriqueceu esta famosa Província da India Ocidental, como consta pela geral autoridade dos Botânicos e viajantes do Orbe, e pelas curas estupendas que vulgarmente aqui operam os curiosos empíricos e selvagens, administrando remédios eficazes tirados de vegetais indígenas; estando eu persuadido e certificado do que acabo de referir pelas informações e experiências de que tenho usado e pelas digreções botânicas que tenho feito nos subúrbios desta cidade, faltaria ao meu dever como patriota e bom vassalo, e a obrigação do meu ministério como botânico e médico,... (Ferraz, 1975: 97-99) 
Em 1798, o Senado da Câmara do Rio de Janeiro propôs a elaboração de um questionário sobre os problemas de salubridade na cidade. Acredita-se que tal iniciativa, o questionário, decorreu da constatação da precariedade das condições sanitárias, dada a grande incidência de moléstias ditas endêmicas como sarna, erisipela, impigens, tuberculose, bouba, morféia, elefantíase, bichos-do-pé, leucirréia, dispepsia, hemorróida, edemas de pernas. Entre as moléstias de caráter epidêmico registravam-se as febres intermitentes, a epidemia das bexigas (varíola).

O questionário solicitava, aos principais médicos da cidade, suas opiniões sobre as possíveis influências do clima, da dieta alimentar e dos hábitos na incidência dessas moléstias, da seguinte forma:

$1^{\circ}$ - Quais são as moléstias endêmicas da cidade do Rio de Janeiro, e quais as epidêmicas.

$2^{\circ}$ - Se é uma das principais causas das primeiras, e do mau sucesso das segundas, o clima nimiamente úmido e quente.

$3^{\circ}$ - Se são causas da umidade. $I^{\circ}$ a suma baixeza do pavimento da Cidade relativamente ao mar e baía (...); II $^{\circ}$ a pouca expedição que tem as águas das chuvas copiosíssimas, principalmente de verão (...); III $^{\circ}$ a pouca circulação do ar pelas ruas da Cidade e interior dos edifícios.

$4^{\circ}$ - Se são causas do calor $\mathrm{I}^{\mathrm{O}} \mathrm{o}$ impedimento, que fazem à entrada dos quotidianos ventos matutinos ou terrais (...); $\mathrm{II}^{\mathrm{o}}$ a direção das ruas (...).

$5^{\circ}$ - Se são causas das mesmas doenças, $\mathrm{I}^{\circ}$ as imundices, que se conservam dentro da Cidade, $\mathrm{II}^{\circ}$ as águas estagnadas nos seus arrabaldes (...)

$6^{\circ}$ - Quanto deverá ser elevado o pavimento da Cidade, e os edifícios para remediar aquela umidade, e haver saída para as imundices.

$7^{\circ}$ - Quais são as outras causas morais e dietéticas das ditas doenças. (No ano de 1789 se propôs..., 1813)

Os médicos Bernardino Antonio Gomes, Antonio Joaquim de Medeiros e Manuel Joaquim Marreiros responderam aos quesitos propostos pela Câmara. Os textos elaborados em resposta ao questionário, e publicados em $1813^{1}$ no periódico O Patriota, apresentam as concepções médicas então vigentes, especialmente as abordagens referentes à causalidade das moléstias. Manoel Joaquim Marreiros (1813) iniciou suas considerações falando sobre as impropriedades decorrentes das disposições topográficas que interferiam na circulação do ar. O solo encontrava-se impregnado de água, de hidrogênio, proveniente dos charcos, onde abundava a umidade, o que colocava as pessoas em situação vulnerável ao acometimento de moléstias (erisipelas, impigens, sarnas, edemas, febres remitentes e nervosas). Acrescentava outras causas de caráter mais particular, como a direção e disposição de algumas ruas, dificultando a viração; a construção inadequada das casas, com dimensões que impedem a entrada do ar externo; o terreno úmido sobre o qual estão assentadas as construções e a falta de asseio das praças em decorrência dos dejetos ali depositados.

Entre as medidas que propunha, Marreiros assinalava a importância da conservação dos arvoredos, que representavam importantes reservatórios de ar vital. Sublinhava, igualmente, as impropriedades da dieta alimentar praticada, como o uso nocivo do peixe, de fácil deterioração, e de misturas "estimulantes", que aumentavam a voracidade. A constituição física e moral dos indivíduos também poderia ser afetada pela falta de ocupação, principalmente entre as mulheres.

Marreiros afirmava que algumas enfermidades, bastante comuns em outras regiões, adquiriam aqui sintomas próprios, tanto quanto a sua forma de aquisição e sua duração. Entre as medidas mais eficazes para reverter 
o quadro de insalubridade, sugeria a elevação de partes da cidade, a alteração na construção das casas e a eliminação dos dejetos. Ressaltava, ainda, a necessidade de que a polícia atuasse de forma eficiente com relação às numerosas famílias que se encontravam vivendo de forma indigna nas ruas da cidade.

O médico Bernardino Antonio Gomes distinguia, inicialmente, as moléstias endêmicas e epidêmicas, afirmando que muitas das doenças que grassavam de forma epidêmica em outros países aqui não agiam da mesma maneira. Admitia a ocorrência de epidemias esporádicas ou extraordinárias, como o caso da de bexigas em 1797. Caracterizava o conjunto de moléstias (endêmicas ou epidêmicas) que incidiam em nossas terras como doenças de atonia, e afirmava "que por conseqüência se deve classar na ordem das suas causas tudo o que tende a enervar a constituição física dos habitantes, e a produzir os miasmas, que hoje se reconhecem por causas das febres intermitentes e remitentes, e em geral das epidêmicas" (Gomes, 1813: 57).

Indicava como uma das principais causas da incidência de moléstias o clima quente e úmido, que favorecia a putrefação das substâncias animais e vegetais, e conseqüentemente promovia a produção de miasmas. As condições topográficas, tanto a pouca elevação como a proximidade dos morros, eram obstáculos para a plena circulação dos ventos, promovendo a estagnação do ar e o excesso de calor, altamente prejudiciais para a constituição física do homem. A existência de água estagnada e de solos alagadiços era vista como verdadeiro manancial de vapores e, portanto, de miasmas.

Outras causas menos notáveis, mas igualmente perniciosas, eram, segundo Bernardino Antonio Gomes, a imundice, decorrente sobretudo da escravatura, por ocasionar que muitos se agrupassem em recintos pequenos, prejudicando a qualidade do ar que se respirava.

Na questão alimentar, o médico de origem portuguesa ressaltava a impropriedade de certos alimentos que tornavam inertes as primeiras vias pelo excesso de mucosas, como a banana, o aipim, os carás, a batata (algumas espécies), a farinha de mandioca, o mate e o chá. A vida sedentária, principalmente entre as mulheres, era também compreendida como causadora de enfermidades, pois o exercício seria o principal esteio da saúde. A prostituição, originada, segundo Gomes, do ócio e da riqueza fácil, danificava a saúde, embora sua prática, e por conseqüência seus danos, fossem mais excessivos na Europa do que no Brasil. Outra prática que debilitava o brasileiro seria o uso quotidiano de banhos tépidos, devido à transpiração que produz e que, por sua vez, aumenta a frouxidão dos vasos exalantes.

O último médico a responder ao questionário oficial, Antonio Joaquim de Medeiros, concordava com a idéia de que as enfermidades podiam acometer qualquer pessoa, independentemente de sua idade, seu sexo e local de moradia. E acreditava que a situação topográfica desfavorável e a construção inadequada das habitações aumentavam a possibilidade de um quadro sanitário precário.

Afirmava que a principal causa das moléstias endêmicas e da dimensão das epidemias encontrava-se no tipo de clima presente, quente e úmido. As excessivas umidade e depravação do ar decorriam da altura baixa dos pavimentos na cidade, do reduzido esgotamento das águas, da inadequada disposição das ruas e dos edifícios, e do ordenamento dos morros, que impediam a adequada renovação do ar. A imundice das ruas da cidade e a presença de águas estagnadas, juntamente com os aspectos citados anteriormente, constituíam um cenário bastante precário.

A qualidade das águas para o consumo, que anteriormente era identificada como causadora de enfermidades, era referida por Medeiros como boa; para assim considerá-la, Medeiros fundamentava-se 
em experiências realizadas por médicos membros da Sociedade Literária do Rio de Janeiro, criada no Rio de Janeiro em 1786.

Antonio Joaquim de Medeiros (1813) enfatizava as causas de cunho moral e dietético, destacando que a opulência desta respeitável Cidade fez introduzir o luxo, e o luxo a depravação dos costumes, de maneira que dentro da Cidade não faltam casas públicas, onde a mocidade vai estragar a sua saúde, e corromper os costumes de uma boa educação, contraindo novas enfermidades, e dando causas para outras tantas.

Em relação aos demais hábitos sociais, identificava a vida sedentária e o consumo exagerado de comidas e bebidas como também responsáveis pela ocorrência de inúmeras moléstias crônicas.

O estado sanitário precário em que se encontrava a cidade do Rio de Janeiro era avaliado por Medeiros não só como um prejuízo para a população em geral, mas como um gerador de despesas públicas, como ocorrera na epidemia de bexigas (varíola) em 1797. O médico sugeria, então, especificamente para o caso da varíola, a criação de um hospital de inoculação, nos moldes do de Lisboa, onde todos fossem inoculados, inclusive os escravos. Para a melhoria das condições gerais de salubridade da cidade, propunha o arrasamento dos morros do Castelo e de Santo Antonio, o derrubamento de alguns edifícios, a construção de casas sob a fiscalização de engenheiros ou da Câmara, a criação de praças espaçosas, a eliminação dos focos de imundice e o secamento dos locais com água estagnada, além dos devidos cuidados com o gado de corte (para evitar a deterioração da carne a ser consumida).

As observações e considerações apresentadas pelos médicos em resposta ao questionário da Câmara pautavam-se fundamentalmente na teoria miasmática. Afirmava-se que a inalação e o contato com o ar contaminado, com a matéria orgânica em putrefação, podiam ocasionar um desequilíbrio dos gases, os miasmas, o que desencadearia a incidência de doenças. Dessa forma, entendia-se que a causalidade de doenças relacionava-se diretamente a condições do meio ambiente. Era, então, imperioso sanear o meio ambiente, a cidade, secando os pântanos, limpando as ruas, deslocando cemitérios.

\section{A Medicina e a Saúde no Município da Corte}

Até as primeiras décadas do século XIX o exercício da medicina era facultado somente a físicos e cirurgiões portadores de um atestado de habilitação e licenciados pelo cirurgião-mor do Reino, conforme preconizava o regulamento de 23 de maio de 1800. Sua atuação estava restrita à realização de sangrias, à aplicação de ventosas, à cura de feridas e de fraturas, sendo-lhes vetada a administração de remédios internos, que era privilégio dos médicos formados em Coimbra.

Com a vinda da família real, que tornou o Brasil o centro administrativo do Império, foram implementadas importantes medidas administrativas, econômicas e culturais, de impacto sobre a saúde e medicina no país. Nesse contexto transformador, a cidade do Rio de Janeiro será o palco de várias iniciativas culturais e científicas, como a criação da Imprensa Régia, da Biblioteca Nacional, dos primeiros periódicos e de instituições médicas e de ensino.

Orientou a criação dos primeiros estabelecimentos de ensino superior a necessidade da formação de quadros profissionais para os serviços públicos imperativos naquele momento. Assim, em 1808 foram criados dois estabelecimentos de ensino médico-cirúrgico, a Escola de Cirurgia, em Salvador, e a Escola Anatômica, Cirúrgica e Médica do Rio de Janeiro, os únicos centros de formação médica oficial ao longo 
de quase todo o século XIX. A proposta curricular, que inicialmente compreendia apenas os conhecimentos de cirurgia e de anatomia, ampliou-se, passando a abarcar as disciplinas de anatomia e fisiologia, terapêutica cirúrgica e particular, medicina cirúrgica e obstétrica, medicina, química e elementos de matéria médica e de farmácia.

Com a abertura dos portos brasileiros ao comércio exterior, em 1808, tornou-se imperiosa a adoção de medidas que promovessem o saneamento das cidades, especialmente o município da Corte, perante o risco de contaminação por moléstias que chegariam pelos portos. Para a definição de tais providências, foi solicitado um estudo aos conselheiros que integravam a comitiva do príncipe regente dom João em sua chegada ao Brasil. Entre esses estavam Paulo Fernandes Viana (1758-1821), José Corrêa Picanço (17451823), responsável pela criação das escolas médico-cirúrgicas da Bahia e do Rio de Janeiro, e Manoel Vieira da Silva (1753-1826). Este último foi autor do estudo intitulado "Reflexões sobre alguns dos meios propostos por mais conducentes para melhorar o clima da Cidade do Rio de Janeiro", publicado em 1808 e considerado o primeiro sobre o tema a ser impresso no Brasil (Lima, 1900). O conselheiro discutia as causas e soluções para a condição de malignidade da cidade do Rio de Janeiro - os fatores topográficos e climáticos, a localização dos cemitérios, a situação dos matadouros, a questão dos medicamentos - e recomendava a criação de lazaretos para acomodar aqueles que aqui aportassem acometidos por moléstias ou com suspeita de estarem doentes. Manoel Vieira da Silva foi nomeado, em 1809, provedor-mor da Saúde da Corte e Estados do Brasil, com a responsabilidade de fiscalizar o estado de saúde das equipagens das embarcações. Nessa época foi criado, no ancoradouro da ilha do Bom Jesus, um primeiro lazareto provisório.

Em 4 de abril de 1811, tendo em vista o grau de insalubridade da cidade, o príncipe regente dom João criou a Junta da Instituição Vacínica da Corte, subordinada à Fisicatura-Mor, com a atribuição de preparar a vacina antivariólica, que seria propagada no município da Corte e nas demais províncias do império. Os serviços de higiene e saúde pública eram ainda precários, e a vacinação antivariólica funcionava como um dos poucos recursos que apresentavam alguma eficiência. No Rio de Janeiro, de 1811 a 1835, a Junta Vacínica da Corte, então denominada Junta Central de Vacinação, vacinou 102.719 pessoas. Em 1846 a junta foi reestruturada e deu origem ao Instituto Vacínico do Império, também conhecido como Instituto Vacínico da Corte.

O combate às enfermidades também preocupava os médicos fora das instituições oficiais e foi objeto de diversos estudos médicos no período joanino, destacando-se os de Bernardino Antonio Gomes ("Observação botânica médica sobre algumas plantas do Brasil", 1812), Caetano José Cardoso ("Lista de várias plantas indígenas da capitania de Minas Gerais e seus produtos medicinais", 1813), e José Maria Bomtempo ("Sobre algumas enfermidades do Rio de Janeiro, e mui particularmente sobre o abuso geral, e pernicioso efeito da aplicação da preciosa casca peruviana, ou quina", 1814), e Francisco de Melo Franco ("Elementos de higiene", 1814).

Somente nas primeiras décadas do século XIX é que começaram a ser instaladas, na cidade do Rio de Janeiro, as casas de saúde, que eram estabelecimentos particulares, em grande parte de propriedade de médicos. Entre as pioneiras podemos citar a casa de saúde do cirurgião Antonio José Peixoto (18161864), instalada em 1845 no morro da Gamboa. O mesmo cirurgião estabeleceu, dez anos depois, uma nova casa de saúde, na rua de Olinda, no bairro de Botafogo, a qual, com seu falecimento, foi adquirida por Manoel Joaquim Fernandes Eiras (1828-1889), que a transformou na Casa de Saúde Dr. Eiras. 
Com a lei de 30 de agosto de 1828, que extinguira as funções de provedor-mor e os cargos de físicomor e cirurgião-mor do Império, foram definidas atribuições para as câmaras municipais, a partir de então responsáveis pelos serviços de higiene e saúde pública, que até aquele momento haviam sido de responsabilidade da Fisicatura-Mor. Iniciava-se, assim, o processo de descentralização do poder imperial, em grande parte em decorrência das relações locais dominadas pela classe senhorial. Por meio de posturas municipais, as câmaras passaram a regular as diversas questões relativas às condições sanitárias da cidade do Rio de Janeiro, propondo normas a tudo que se remetia à salubridade da cidade, como a iluminação e limpeza das ruas e praças, a conservação das edificações, o estado das calçadas, aquedutos e chafarizes, o esgotamento dos pântanos, a localização dos cemitérios, o trânsito de animais, os matadouros e o reparo de estradas. Nas Posturas da Câmara Municipal do Rio de Janeiro em 1832, em sua seção Vacinas e Expostos, foi estabelecida a obrigatoriedade da vacinação na cidade, determinando-se que todas as pessoas que tivessem sob seu encargo uma criança deveriam encaminhá-las à "casa da vacina para ser vacinada" (apud Falcão, 1978a: 48), sob pena de uma multa pecuniária. Entretanto, tal postura não foi efetivamente adotada.

O decreto de 17 de janeiro de 1829 criou uma comissão especial denominada Inspeção de Saúde Pública do Porto do Rio de Janeiro, que seria constituída por um provedor de saúde, eleito entre os vereadores, um professor de saúde, um intérprete que serviria de secretário, e por guardas.

Os serviços de higiene e saúde pública permaneceram a cargo das câmaras municipais até 1843, quando foi determinado que estas não poderiam mais intervir nas inspeções sanitárias dos portos, nem na nomeação dos seus respectivos empregados, e que tais atribuições ficariam a cargo do Ministério do Império. Desde então, e até o final do regime monárquico no Brasil, ficaram subordinadas à Secretaria de Estado dos Negócios do Império todas as repartições de higiene e saúde, as juntas de Higiene Pública, os lazaretos de quarentena, o Instituto Vacínico do Império, a Faculdade de Medicina do Rio de Janeiro e a Faculdade de Medicina da Bahia, além de todos os órgãos ligados à assistência sanitária.

A institucionalização da higiene e da saúde pública no Brasil está igualmente relacionada à história da Sociedade de Medicina do Rio de Janeiro (atual Academia Nacional de Medicina), criada em 30 de junho de 1829 com o objetivo de viabilizar o crescimento das diversas áreas da medicina e ampliar a participação desses profissionais no governo imperial, especialmente em questões referentes à higiene e às políticas de saúde pública. Entre seus fundadores estavam Joaquim Cândido Soares de Meirelles (17971868), Francisco Freire Allemão de Cysneiros (1797-1874), José Martins da Cruz Jobim (1802-1878), Francisco de Paula Cândido (1805-1864) e o francês José Francisco Xavier Sigaud (1796-1856), autor da obra Du Climat et des Maladies du Brésil (1844), considerada uma síntese do pensamento higienista no Brasil da primeira metade do século XIX. A Sociedade de Medicina do Rio de Janeiro foi instalada inicialmente na Casa do Consistório da Igreja do Rosário, funcionou em outras localidades na cidade, e em 1861 foi transferida para o Paço Municipal da Corte, localizado próximo ao Campo de Santana. Somente em 1953 iniciou a construção de sua sede própria, no número 35 da avenida General Justo.

A instalação de hospitais dedicados especialmente ao atendimento de alienados deu-se somente em meados do século XIX, destacando-se a criação, em 1841, por José Clemente Pereira, provedor da Santa Casa da Misericórdia do Rio de Janeiro, do Hospício de Pedro II, em terreno na praia Vermelha, no prédio que atualmente abriga o Palácio Universitário da Universidade Federal do Rio de Janeiro. 


\section{As Epidemias e a Regularização da Saúde no Império}

Na segunda metade do século XIX a saúde pública no Brasil passou por diversos problemas, começando com o surgimento, em 1849, da febre amarela na Bahia, depois em todos os portos do norte e finalmente no Rio de Janeiro. Diante da ameaça da febre amarela foi instalado um lazareto provisório na ilha de Bom Jesus dos Frades, para onde eram transferidos os homens do mar, e aqueles que já estavam doentes eram encaminhados para a Santa Casa da Misericórdia do Rio de Janeiro. Foram, também, estabelecidos os hospitais de Nossa Senhora do Livramento e o Hospital Marítimo de Santa Izabel, situado na enseada de Jurujuba, na entrada do porto, e diversas enfermarias em vários pontos da cidade.

Em 1849, tendo em vista os perigos da febre amarela, o governo imperial criou uma Comissão Central de Saúde Pública, constituída por médicos filiados à Academia Imperial de Medicina: Cândido Borges Monteiro (presidente), Manoel de Valadão Pimentel, Roberto Jorge Hadock Lobo, Antonio Felix Martins, José Maria Noronha Feital, José Bento da Rosa, José Pereira Rego, Luiz Vicente Simoni, José Francisco Sigaud e Joaquim José da Silva. Para um combate mais eficaz à epidemia, foram criadas, ainda, as comissões paroquiais, que ficariam subordinadas àquela comissão e também seriam formadas por doutores em medicina. As comissões formadas tinham como incumbência velar, durante a epidemia, pela observância das leis, ordens e providências relativas à saúde pública, e visitar gratuitamente todos os doentes pobres de sua freguesia.

Apesar de todas essas medidas, as estatísticas da época ainda revelavam altos índices de mortalidade por febre amarela. No verão de 1849-1850 a epidemia de febre amarela no Rio de Janeiro foi controlada, mas o governo imperial, buscando a prevenção de novas epidemias, criou por meio do decreto n. 598, de 14 de setembro de 1850, a Junta de Higiene Pública, com as seguintes atribuições:

Propor ao governo todas as medidas, que julgar necessárias ou convenientes a bem da salubridade pública, e informar sobre as que lhe forem indicadas pelo governo. Entender na efetiva execução das Posturas da Câmara Municipal relativas a objeto de salubridade pública, e indicar-lhe as medidas que julgar necessárias ou convenientes para que se convertam em Posturas, recorrendo para o governo (...) quando não for atendida; Exercer polícia médica nas visitas das embarcações até agora encarregadas à inspeção da Saúde do Porto, e nas que devem fazer-se nas boticas, lojas de drogas, mercados, armazéns, e em geral em todos os lugares, estabelecimentos, e casas donde possa provir dano à Saúde Pública. (Brasil, 1951)

A Junta de Higiene Pública, que funcionaria na capital do Império, na cidade do Rio de Janeiro, seria constituída por um presidente, nomeado pelo governo imperial, dois cirurgiões-mores da Armada e do Exército, um inspetor do Instituto Vacínico do Império e um provedor de Saúde do Porto. Nessa época também foi criada uma Comissão de Engenheiros, composta por quatro oficiais escolhidos pelo governo, aos quais caberia a função de desenhar plantas e fazer propostas e orçamentos das obras e serviços necessários aos melhoramentos sanitários da cidade, além de auxiliar a Junta de Higiene Pública. A primeira composição da Junta de Higiene Pública teve Francisco de Paula Cândido (presidente), Joaquim Cândido Soares de Meirelles, Antonio José Ramos (cirurgião-mor da Armada), Jacintho Rodrigues Pereira Reis (cirurgião-mor do Exército), Antonio Felix Martins (provedor-mor de Saúde do Porto) e Ernesto Augusto Lassance Cunha (secretário). 
A junta, que a princípio seria um conselho consultivo, acabou ficando responsável pelo serviço sanitário do Império, atuando principalmente em momentos de epidemias de febre amarela, cóleramorbo e varíola. Reunia os serviços de Inspeção de Saúde do Porto e do Instituto Vacínico, incumbindose da higiene e saúde pública tanto em terra quanto no mar.

Esse modelo de junta de higiene pública foi adotado em outras províncias do império, como Pará, Maranhão, Pernambuco, Bahia e Rio Grande do Sul, onde também foram estabelecidas comissões de Higiene Pública. Em 1851 a Junta de Higiene Pública passou ser denominada Junta Central de Higiene Pública e a concentrar todo o serviço sanitário do Império, exercendo sua autoridade nas outras províncias por intermédio das comissões e dos provedores que se encontravam sob sua tutela. A Inspeção de Saúde dos Portos e a Inspeção da Vacinação ficaram definitivamente incorporadas e sob a direção da junta.

O presidente Francisco de Paula Cândido, buscando prevenir uma futura epidemia, alugou, em 1851, uma casa para receber enfermos, na península do Caju, na enseada de Jurujuba. Tendo em vista as más condições de acomodação desse lazareto, foi promulgado um decreto em 3 de janeiro de 1853, que estabeleceu a fundação de um hospital que viria a receber o nome de Hospital Marítimo de Santa Izabel, posteriormente Hospital Paula Cândido.

Em 1857 determinou-se que as comissões de Higiene Pública, criadas anteriormente nas províncias, fossem extintas e substituídas por um inspetor de saúde pública, denominação que também passaram a ter os provedores.

Um decreto do governo imperial conferiu, em 1859, um novo regulamento à Inspeção de Saúde do Porto, em substituição ao de 1843, que já não correspondia mais às funções e necessidades para as quais havia sido criado antes das epidemias de febre amarela e de cólera-morbo. Entretanto, o novo decreto não atendeu ao proposto, e em 1861 outras resoluções foram apresentadas, estabelecendo normas para o Hospital Marítimo de Santa Izabel e os demais lazaretos do império, os quais só poderiam receber doentes quando o governo julgasse indispensável ou quando os portos fossem ameaçados por alguma epidemia que não pudesse ser tratada nos estabelecimentos de caridade.

Com o impacto da Guerra do Paraguai, iniciada em 1864, deixaram de ser implementadas, nesse período, ações importantes ou legislações no campo da saúde pública. No ano de 1876 o governo imperial tornou a dirigir sua atenção para a questão da saúde pública, nomeando uma comissão com a incumbência de estudar especialmente os motivos que haviam ocasionado a persistência e o desenvolvimento da febre amarela nos últimos anos, e de propor as melhores maneiras de erradicá-la. Essa comissão foi presidida por José Pereira Rego (barão do Lavradio), que à época era também presidente da Junta Central de Higiene Pública, e constituída por médicos igualmente reconhecidos, como Antonio Corrêa de Souza Costa, João Vicente Torres Homem, Vicente Cândido Figueira de Sabóia, Hilário Soares de Gouvêa e João Baptista dos Santos. Com essa composição reiterava-se o importante papel atribuído aos médicos na definição de ações e medidas em prol da saúde pública. A comissão encaminhou ao governo imperial dois relatórios e projetos apresentando as providências a serem tomadas e indicando medidas de promoção da melhoria das condições higiênicas da cidade, como o combate aos locais insalubres e a reorganização dos serviços sanitários terrestres e marítimos de todo o império. Entre as medidas de prevenção propostas, e que foram convertidas posteriormente em posturas pela Câmara Municipal, estavam a proibição do despejo de lixo em praias, aterros e outros lugares, e do estabelecimento 
de hospitais. Postura municipal de 6 de outubro de 1876 proibiu o estabelecimento de novos hospitais e casas de saúde, ou o aumento daqueles já estabelecidos, dentro da zona delimitada, "a começar no mar, junto ao morro da Gloria, segue pela rua da Lapa, rua das Mangueiras, rua do Riachuelo, rua Frei Caneca, rua do Estácio de Sá, largo do mesmo nome, rua de S. Christovão, rua dos Lázaros, a terminar no mar" (apud Falcão, 1978a: 216). A mesma postura municipal ainda determinou que nos hospitais e casas de saúde gerais, ou seja, naqueles estabelecimentos que acolhiam pacientes com quaisquer moléstias, não seria permitido o recolhimento de pessoas acometidas por febre amarela, varíola, cólera e outras enfermidades epidêmicas e contagiosas.

O decreto imperial n. 6.376, de 15 de novembro de 1876, procurou atender à necessidade de providências com relação à importação e desenvolvimento de moléstias contagiosas e infectocontagiosas em diversos portos e cidades marítimas do império, levando em consideração o parecer da comissão que havia sido anteriormente nomeada pelo governo imperial com esse propósito. Entre as disposições, havia a determinação de que a Junta Central de Higiene Pública seria auxiliada por médicos especiais, nomeados pelo ministro dos Negócios do Império, e que seria criado de forma provisória, e próximo ao Hospital Marítimo de Santa Izabel, um lazareto flutuante destinado à quarentena dos passageiros procedentes de portos onde grassassem febre amarela, cólera, entre outras doenças. O lazareto ficaria subordinado ao inspetor de Saúde do Porto, o qual passaria a contar com quatro ajudantes. As comissões de Higiene provinciais foram restabelecidas nas províncias da Bahia, Pernambuco, Maranhão, Pará, São Paulo e Rio Grande do Sul. Os postos vacínicos das freguesias urbanas foram suprimidos e as paróquias urbanas foram divididas em distritos, denominados distritos sanitários, a cargo de seus médicos correspondentes. A distribuição das paróquias se deu da seguinte forma: as de Nossa Senhora da Conceição do Engenho Novo e de Nossa Senhora da Candelária, com um distrito; as do Santíssimo Sacramento, São José, Santo Antônio, Divino Espírito, São Francisco Xavier do Engenho Velho e São Cristóvão, com dois distritos; as de Nossa Senhora da Glória, Santana e Santa Rita, com três distritos. As de São João Batista da Lagoa e de Nossa Senhora da Conceição da Gávea formariam um só distrito.

Ainda em 1876, outro decreto imperial estabeleceu instruções relativas ao serviço sanitário, que foram divididas entre os serviços da cidade e os do porto. Os serviços a cargo da Junta Central de Higiene Pública seriam:

1) Estudo das epidemias, moléstias reinantes e epizootias, e dos meios de as prevenir e combater. Inspeção das farmácias, drogarias e fábricas de águas minerais e de drogas medicinais. Matrícula dos médicos e farmacêuticos, e fiscalização do exercício da medicina e farmácia. 2) Inspeção das bebidas e dos gêneros alimentícios, expostos à venda, bem como dos estabelecimentos e casas onde fossem fabricados, preparados ou vendidos. Vigilância sobre o modo de execução dos serviços do abastecimento d'água à cidade; limpeza pública e irrigação das ruas e praças, no que fosse relacionado à salubridade pública. 3) Estudo sobre as condições higiênicas dos edifícios públicos e particulares que fossem construídos. Saneamento dos cortiços ou estalagens e dos mictórios públicos. 4) Administração de socorros médicos à pobreza. Inspeção das fábricas, oficinas, laboratórios e outros estabelecimentos particulares. Das localidades de onde possa resultar dano à saúde pública, e dos estabelecimentos onde se recolhessem animais. 5) Vigilância sobre a higiene dos quartéis, arsenais, asilos e outros estabelecimentos públicos. Inspeção sanitária dos cemitérios e depósitos de cadáveres. (Brasil, 1978) 
O governo imperial autorizou, em 5 de abril de 1878, a nomeação das comissões paroquiais para auxiliar a Junta Central de Higiene Pública nos serviços de melhoria das condições de salubridade e higiene da cidade do Rio de Janeiro. A junta ficou novamente encarregada de organizar o novo plano de melhoramentos para preservar a cidade das epidemias. Novos decretos foram editados, determinando as medidas sanitárias a serem adotadas em casos de iminência de qualquer epidemia, como a transferência dos casos suspeitos ou confirmados para o Hospital Marítimo e, se necessário, para um hospital flutuante na mesma enseada de Jurujuba, e a permissão à autoridade sanitária para ordenar o afastamento dos navios do litoral pelo tempo que julgasse conveniente.

Entre os anos de 1876 e 1879, não houve ações expressivas em relação à saúde pública, porém entre 1881 e 1886 foram empreendidas pelo governo imperial algumas reformas nos serviços sanitários. Em 19 de fevereiro de 1881 o governo imperial exonerou o barão do Lavradio da presidência da junta, da direção do Instituto Vacínico e da Inspeção de Saúde do Porto, e nomeou João Baptista dos Santos (1828-1911) para a Junta Central de Higiene Pública, Nuno Ferreira de Andrade (1851-1922) para a Inspeção de Saúde do Porto e Peregrino José Leite para o Instituto Vacínico. No mesmo ano, foram adotadas outras providências em relação à assistência e à saúde, tais como:

$1^{a}$ autorização à Junta de Higiene para organizar o serviço das desinfecções; 2a recomendando aos administradores, diretores e donos de hospitais e casas de saúde que não recebessem nesses estabelecimentos doentes de moléstias infecto-contagiosas, enquanto revestissem a forma esporádica; $3^{a}$ requisitando do provedor da Santa Casa da Misericórdia a proibição de enterramento de cadáveres de pessoas indigentes no cemitério de São João Batista, o estabelecimento nos novos quadros do dito cemitério de sistema de drenagem que preenchesse as condições de higiene exigidas pela salubridade pública, a elevação do muro do mesmo cemitério do lado da localidade denominado Izabelópolis e a plantação de eucaliptos e outras árvores apropriadas ao lugar. (Barbosa \& Rezende, 1909: 81)

Pelo decreto n. 8.387, de 19 de janeiro de 1882, reafirmaram-se as atribuições da Junta Central de Higiene Pública, em tudo que se relacionasse à saúde pública; propôs-se a criação de uma Comissão de Higiene Pública em cada paróquia do município da Corte, de uma Junta de Higiene na capital de cada uma das províncias do Pará, Maranhão, Pernambuco, Bahia e Rio Grande do Sul; definiu-se o estabelecimento de um inspetor de higiene pública nas demais províncias (Brasil, 1889a).

A epidemia de varíola agravou-se em 1883, preocupando as autoridades com relação à vacinação da população. Em 19 de dezembro do mesmo ano foram estabelecidas duas comissões vacínico-sanitárias como auxiliares da Junta e do Instituto Vacínico.

Em 22 de dezembro de 1883 foi regulamentado o Laboratório de Higiene da Faculdade de Medicina do Rio de Janeiro, destinado não só aos alunos da cadeira de higiene daquela instituição, mas também à realização de análises de drogas, bebidas e gêneros alimentícios de interesse da saúde pública, sob a orientação da Junta Central de Higiene Pública.

Em 1884 o ministro do Império, Felippe Franco de Sá, determinou a construção de um lazareto quarentena, sugerido anteriormente por Nuno Ferreira de Andrade, a ser instalado na ilha Grande. O lazareto, cujas obras se concluíram em 1886, foi considerado um dos melhores do gênero, com capacidade para 1.500 pessoas.

O quadro nosológico da cidade do Rio de Janeiro, a despeito de todas as medidas referidas anteriormente, não havia se alterado muito, ainda apresentando números expressivos de acometidos 
por febre amarela e varíola. Com o decreto n. 9.554, de 3 de fevereiro de 1886, o serviço sanitário do Império foi reorganizado, passando a compreender o serviço sanitário terrestre e o serviço sanitário dos portos. O primeiro ficaria a cargo da Inspetoria Geral de Higiene e o segundo sob responsabilidade da Inspetoria Geral de Saúde dos Portos, ambas com sua sede na capital do Império.

A Inspetoria Geral de Higiene respondia pelos serviços terrestres de saúde pública, tendo como atribuições:

I. A fiscalização do exercício da medicina e da farmácia; II. O estudo das epidemias, epizootias e moléstias reinantes; III. A direção do serviço de vacinação o estudo dos meios de melhorá-lo e desenvolve-lo; IV. A direção de socorros sanitários aos necessitados; V. A polícia sanitária sobre tudo que, direta ou indiretamente, interessar a saúde dos habitantes das cidades, vilas e povoados do Império; VI. A organização das estatísticas demografo-sanitárias; VII. A organização e aperfeiçoamento do Código Farmacêutico brasileiro. (Brasil, 1886)

À Inspetoria Geral de Higiene foram atribuídos os serviços que zelassem pelo bem-estar da higiene e da saúde pública: a fiscalização do serviço de limpeza pública; o exame das águas para consumo; o estudo de todos os projetos, planos e propostas de construções públicas, no que se referisse à saúde e higiene públicas, assim como as condições higiênicas dos edifícios e estabelecimentos públicos já existentes; o exame da higiene das indústrias já estabelecidas; a concessão ou negação de licença para a venda de preparados medicinais e para a instalação de hospitais particulares, casas de saúde e maternidades; a organização de planos de socorros públicos e a vigilância ativa sobre o serviço sanitário.

A Inspetoria de Saúde dos Portos, criada para promover os serviços marítimos de saúde, teria as seguintes incumbências: "I. A direção dos socorros médicos aos homens do mar; II. A polícia sanitária dos navios, dos ancoradouros e do litoral; III. O serviço das quarentenas marítimas; VI. O estudo de todas as questões que interessem ao melhoramento das condições sanitárias dos portos" (Brasil, 1886).

Ainda seriam atribuições da Inspetoria Geral de Saúde dos Portos os serviços da polícia sanitária do litoral, dos ancoradouros e dos navios; a concessão ou negação de licenças, em época de epidemias; a divisão dos serviços da quarentena e a superintendência dos serviços do hospital marítimo e do lazareto; a expedição de instruções aos inspetores de saúde dos portos provinciais.

O decreto de 1886 estabeleceu, ainda, a criação, na Corte, de um Conselho Superior de Saúde Pública, responsável por consultas sobre as questões de higiene e salubridade geral, sempre que o governo imperial necessitasse de tais subsídios. Seria composto pelos responsáveis por duas importantes instituições de referência na saúde, o presidente da Academia Imperial de Medicina e o diretor da Faculdade de Medicina do Rio de Janeiro.

Foi organizada, ainda em de 1886, uma Comissão de Saneamento do Rio de Janeiro, chefiada pelo engenheiro britânico Jules Jean Revy, a qual teria como atribuições a realização de estudos sobre a origem e natureza dos terrenos pantanosos, sobre as obras de drenagem, dessecamento ou aterro, sobre o regime dos rios e as obras de canalização necessárias para o saneamento da cidade do Rio de Janeiro, e a organização de um plano de melhoria dos esgotos.

Em 1889, a partir da proposta encaminhada por Benjamin Antonio da Rocha Faria (1853-1936), lente da cadeira de higiene da Faculdade de Medicina do Rio de Janeiro, a Vicente Cândido Figueira de Sabóia, diretor da instituição, o Serviço de Análises e Exames foi separado do Laboratório de Higiene e foi criado o Instituto de Higiene da Faculdade de Medicina do Rio de Janeiro. Essas modificações foram 
aprovadas pelo decreto n. 10.230 de 13 de abril de 1889, que definiu como objetivos do instituto a instrução dos alunos da cadeira de higiene, o estudo das epidemias e epizootias, a instrução higiênica especializada aos docentes das escolas primárias e aos alunos da Escola Normal e a disseminação das noções indispensáveis de higiene pessoal e domiciliar pela população do município da Corte. Em contrapartida, o serviço de análises e exames de bebidas, substâncias alimentares e outras substâncias de interesse da saúde pública seria feito por um laboratório específico, o Laboratório do Estado, criado pelo mesmo decreto (Brasil, 1889b).

Esse estabelecimento, que se transformou mais tarde no Laboratório Nacional de Análises, funcionava em uma dependência da Alfândega. O decreto n. 6.418, de 30 de outubro de 1889, último ato do governo imperial em relação à saúde pública, organizou e regulamentou o Serviço de Vacinação Anticarbunculosa, sob o encargo do Laboratório de Fisiologia Experimental do Museu Nacional, que havia sido criado em 1880.

Em 1890, o decreto n. 169 definiu a constituição de um Conselho de Saúde Pública e a reorganização do serviço sanitário terrestre da República. O serviço sanitário terrestre ficaria a cargo da Inspetoria Geral de Higiene, com sede na cidade do Rio de Janeiro, então capital federal. À inspetoria caberiam o estudo das questões de higiene pública, o saneamento das localidades, a adoção de meios de prevenção de epidemias e endemias, a organização dos socorros públicos, a direção do serviço de vacinação, a inspeção sanitária das escolas, fábricas, dos hospitais, hospícios e de outras habitações coletivas, a fiscalização da alimentação pública, a fiscalização do exercício da medicina, a polícia sanitária, a organização da estatística demógrafo-sanitária e a fiscalização sanitária de cemitérios e outras construções suscetíveis de comprometer a saúde pública. Entre as atribuições dos delegados de higiene estava a fiscalização das condições físicas e de funcionamento de instituições hospitalares e das casas de saúde.

A execução de tais serviços se faria pela autoridade da Inspetoria Geral de Higiene, por seu delegado de Higiene na capital federal e pelas inspetorias de Higiene e respectivos delegados nos estados. O mesmo decreto determinou ainda a criação de um Conselho de Saúde Pública, igualmente sediado na capital federal, e que seria "incumbido de interpor parecer acerca das questões de higiene e salubridade geral sobre que for consultado pelo Governo" (apud Falcão, 1978b: 715).

Durante todo o século XIX foi crescente, entre os administradores e os médicos, a preocupação com as condições de salubridade da cidade, conforme expressam a extensa legislação, a criação de órgãos públicos e a elaboração de inúmeros estudos. A assistência médico-hospitalar na cidade do Rio de Janeiro realizou-se, ao longo de todo esse período, notadamente em instituições assistenciais, laicas ou confessionais. Procurava-se, por esses meios, combater as enfermidades que grassavam na cidade, e assim torná-la mais salubre e mais "civilizada".

Com a República e a promulgação da Constituição de 1891, promoveu-se a reorganização das atribuições e a definição de responsabilidades das esferas municipal e federal. Se anteriormente as ações no campo da assistência e da saúde caracterizaram-se pela ausência de um caráter mais efetivamente público, no contexto republicano a saúde pública passou ao domínio estatal, em termos de sua organização e locais de atuação. 
Nota

${ }^{1}$ As fontes primárias e secundárias consultadas, que abordam a realização deste questionário, não esclarecem a razão de a publicação das respostas às perguntas nele contidas ter se realizado somente em 1813.

\section{Referências}

BARBOSA, P. \& REZENDE, C. B. de. Os Serviços de Saúde Pública do Brasil, especialmente na Cidade do Rio de Janeiro de 1808 a 1907: esboço histórico e legislação. Rio de Janeiro: Imprensa Nacional, 1909.

BRASIL. Decreto n. 9.554 de 03 de fevereiro de 1886. In: Colleção de Leis do Império do Brazil de 1886, Tomo XXXIII, parte I. Actos do Poder Executivo. Rio de Janeiro: Typographia Nacional, 1886.

BRASIL. Decreto n. 8.387 de 19 de janeiro de 1882. In: Colleção de Leis do Brazil de 1882, Tomo XXIX, parte II. Tomo XLV. Rio de Janeiro: Typographia Nacional, 1889a.

BRASIL. Decreto n. 10.232 de 13 de abril de 1889. In: Colleção das Leis do Império do Brazil de 1889, Parte I, Tomo XXXVI, v. I. Rio de Janeiro: Imprensa Nacional, 1889b.

BRASIL. Decreto n. 598 de 14 de setembro de 1850. In: Colleção de Leis do Brasil, 1850, Tomo XI, parte I. Rio de Janeiro: Typographia Nacional, 1951.

BRASIL. Decreto n. 828 de 29 de setembro de 1851. In: Colleção de Leis do Império do Brazil, 1851, Tomo XIV, parte II, secção 59a. Rio de Janeiro: Typographia Nacional, 1952.

BRASIL. Decreto n. 6.406 de 13 de dezembro de 1876. In: FALCÃO, E. de C. Brasilliensia Documenta, VI, Osvaldo Cruz Monumenta Histórica, Tomo IV (II). Os Serviços de Saúde Pública no Brasil (1808-1907): legislação. São Paulo: s. n., 1978.

FALCÃO, E. C. Brasilliensia Documenta, VI, Osvaldo Cruz Monumenta Histórica, Tomo IV (I). Os Serviços de Saúde Pública no Brasil (1808-1907): legislação. São Paulo: s. n., 1978a.

FALCÃO, E. C. Brasilliensia Documenta, VI, Osvaldo Cruz Monumenta Histórica, Tomo IV (II). Os Serviços de Saúde Pública no Brasil (1808-1907): legislação. São Paulo: s. n., 1978b.

FERRAZ, Manuel Joaquim de Sousa. Correspondência ao Conde de Resende. 9 dezembro 1795. In: VARNHAGEN. História Geral do Brasil. Tomo V. São Paulo: Cia. Melhoramentos de São Paulo, 1975.

GOMES, B. A. Resposta que deu o Doutor Bernardino Antonio Gomes ao Programa da Câmara desta Cidade, que vem no no 1 . O Patriota, Rio de Janeiro, n. 2, p. 56-58, fev. 1813.

LIMA, A. J. S. Parte segunda 1808-1900. In: Livro do Centenário. Rio de Janeiro, Imprensa Nacional, 1900. v. 2.

MARQUES, V. R. B. Natureza em Boiões: medicinas e boticários no Brasil setecentista. Campinas: Editora da Unicamp, 1999.

MARREIROS, M. J. Resposta, que deu o Doutor Manoel Joaquim Marreiros aos quesitos precedentes. O Patriota, Rio de Janeiro, n. 1, p. 60-67, jan. 1813.

MEDEIROS, A. J. Resposta, que ao Programma da Câmara annunciado no $\mathrm{N}^{\circ} 1$ pag.58, deu o Doutor Antonio Joaquim Medeiros. O Patriota, n. 3, p. 3-15, mar. 1813.

NO ANO DE 1798 se propôs por Acordo da Câmara desta Cidade a vários Médicos, um programa que tinha por objeto os quesitos seguintes. O Patriota, n. 1, p. 58-59, jan. 1813.

PIMENTA, T. S. Transformações no exercício das artes de curar no Rio de Janeiro durante a primeira metade do Oitocentos. História, Ciências, Saúde - Manguinhos, 11 (supl. 1): 67-92, 2004.

RIBEIRO, M. M. A Ciência dos Trópicos: a arte médica no Brasil do século XVIII. São Paulo: Hucitec, 1997. 


\section{Faculdade de \\ Medicina, Praia}

Vermelha, [1940].

Medicina da UFRJ

Símbolo da luta da

Faculdade de

Medicina para ter um

espaço próprio, fora

das dependências da

Santa Casa da

Misericórdia, este

prédio foi inaugurado em 1918 com apenas dois andares. Nele funcionavam alguns laboratórios, as salas de aula e os gabinetes dos professores. Nos anos 1940 ganhou mais dois andares. Foi destruído na década de 1970.
Acervo Faculdade de

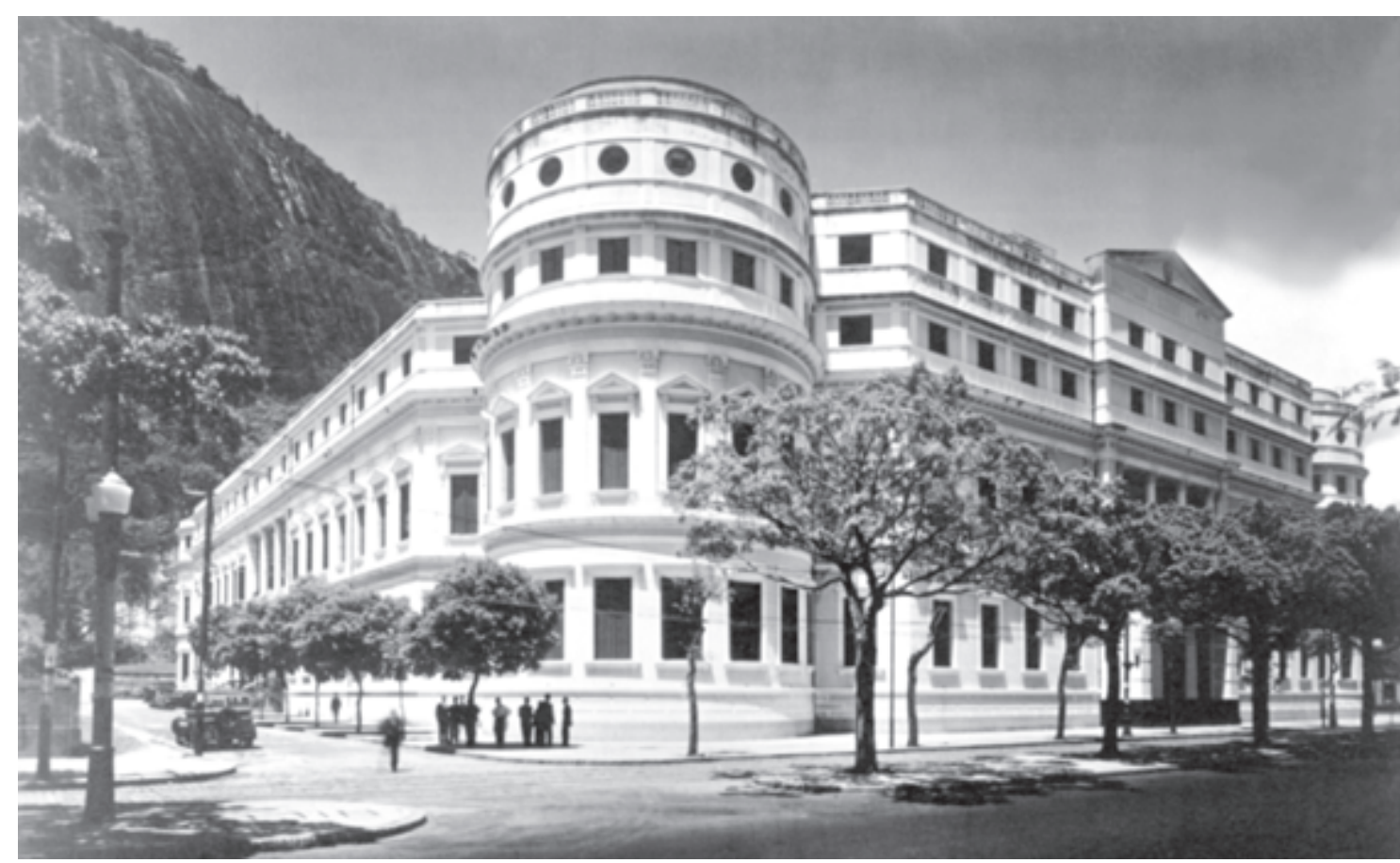

Hospital Central do Exército - Pavilhão F. Peixoto, [s.d.]. Foto Augusto Malta. Acervo Museu da Imagem e do Som, RJ

O Hospital Central do Exército, no bairro da Triagem, foi construído entre 1892 e 1902, seguindo o modelo de hospitais pavilhonares, do final do século XIX, quando o medo do contágio fez com que as especialidades médicas ocupassem um único edifício (pavilhão) de no máximo dois andares. Nos anos 1980 os antigos pavilhões foram substituídos por modernas edificações, à exceção deste.

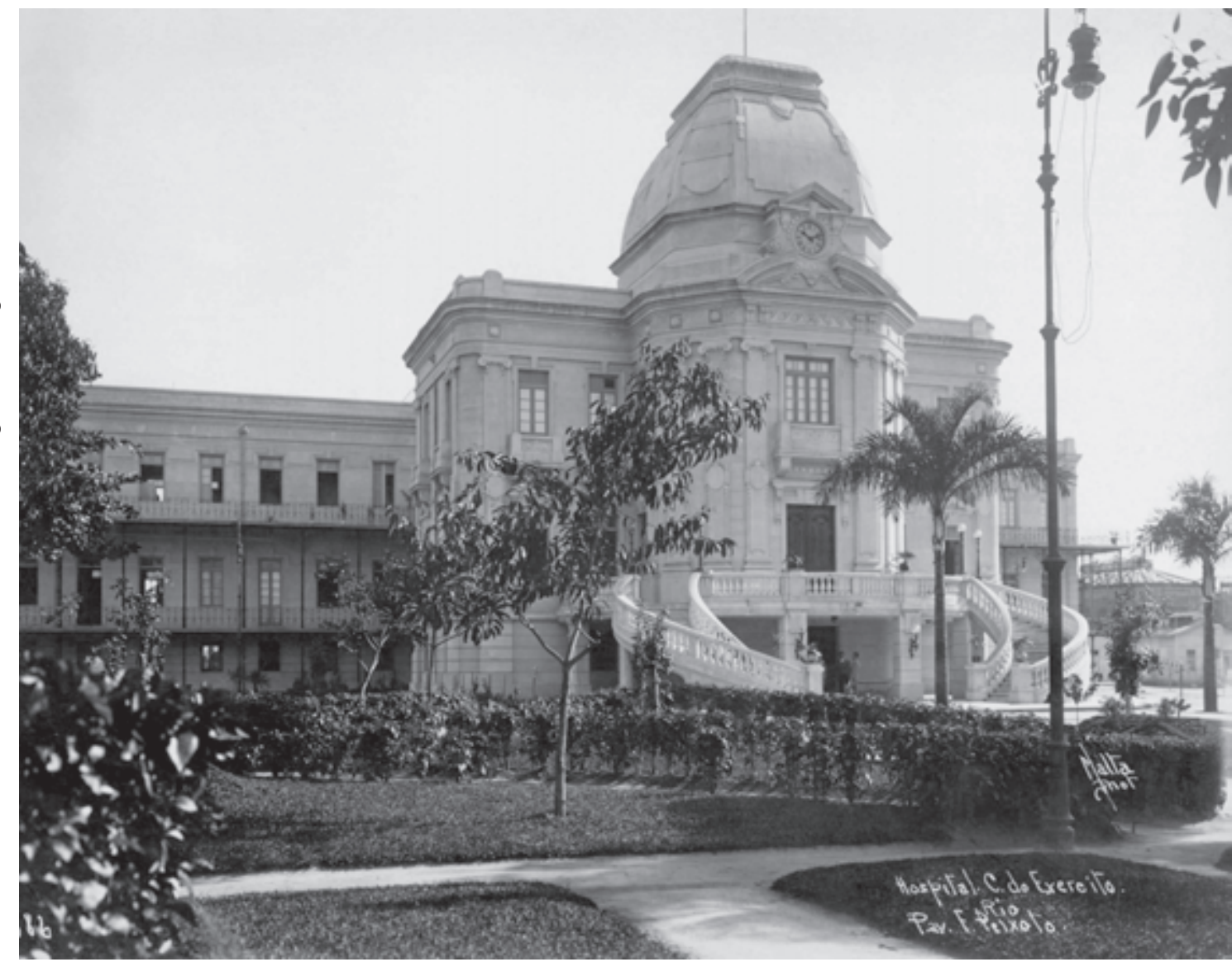



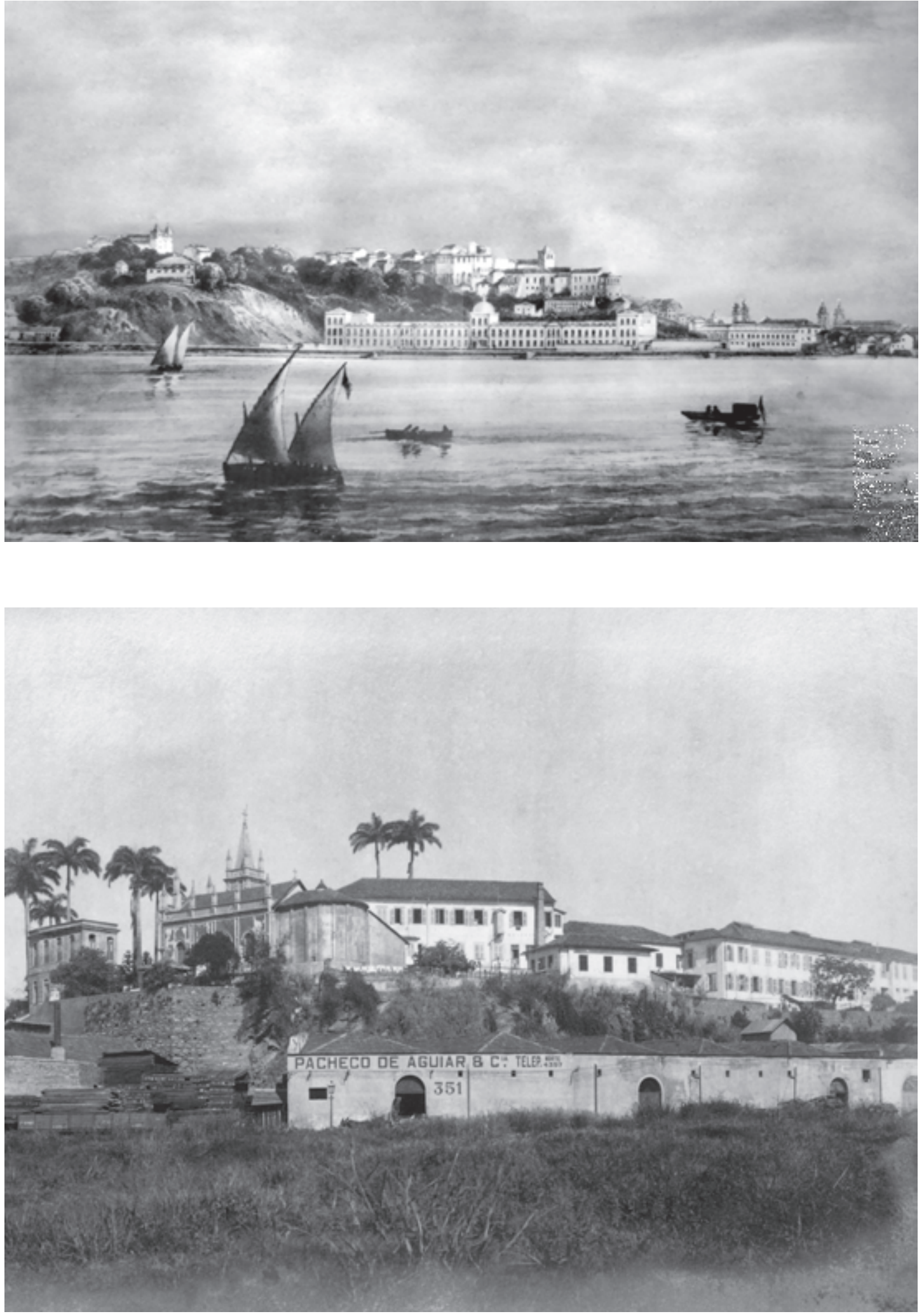

Vista do Hospital da Misericórdia,

Victor Frond, [s.d.]

Acervo IHGB

Vista do edifício do Hospital Geral da Santa Casa, construído entre 1840 e 1850.
Hospital Nossa Senhora da Saúde, [s.d.]. Acervo Instituto

Hahnemanniano do Brasil

Segunda enfermaria construída pela Irmandade da Misericórdia, em cumprimento às exigências do governo imperial. A Santa Casa instalou o Hospital Nossa Senhora da Saúde, em 1853, nas instalações da Casa de Saúde do Dr. Peixoto. É neste edifício, reformado para recebê-lo, que o hospital funciona até hoje. 


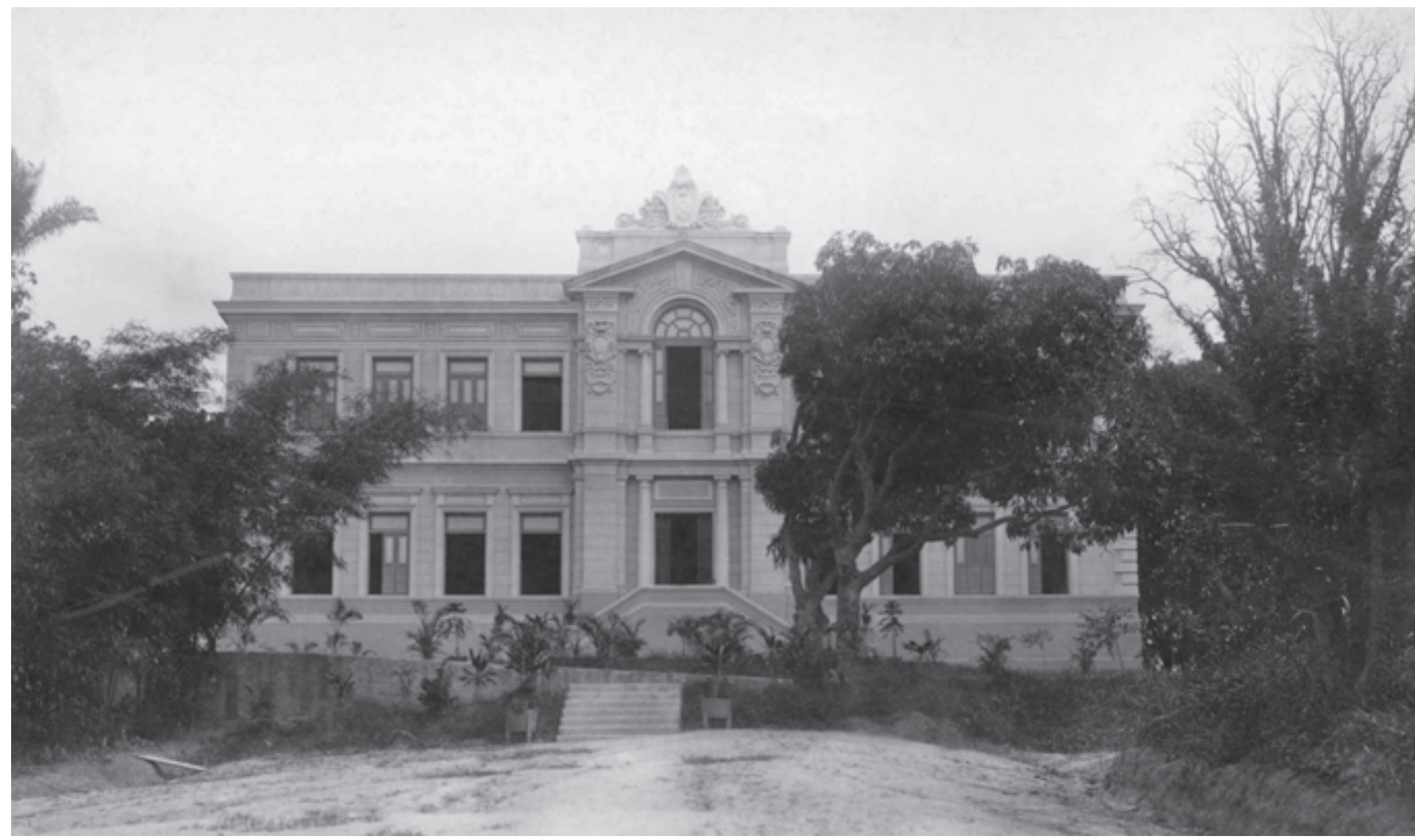

Hospício Nossa Senhora das Dores, [s.d.]. Foto Augusto Malta. Acervo Museu da Imagem e do Som, RJ

Em 1884, a Irmandade da Misericórdia adquire a Chácara do Ferraz, em Cascadura, para lá instalar o Hospício de Nossa Senhora das Dores, destinado ao atendimento de mulheres tuberculosas. Na década de 1910 o prédio passou por modificações e ampliações, que guarda até hoje.

Hospício Nossa Senhora do Socorro, [s.d.]. Acervo Museu da Imagem e do Som, RJ

Terceira enfermaria criada pela Irmandade da Misericórdia para responder a imposição do governo imperial, o Hospício Nossa Senhora do Socorro foi inaugurado em 1853 e destinava-se a atender os moradores das freguesias de São Cristóvão e do Caju. O prédio foi construído na década de 1870 e destruído por um incêndio em 1920, quando foi totalmente reconstruído.

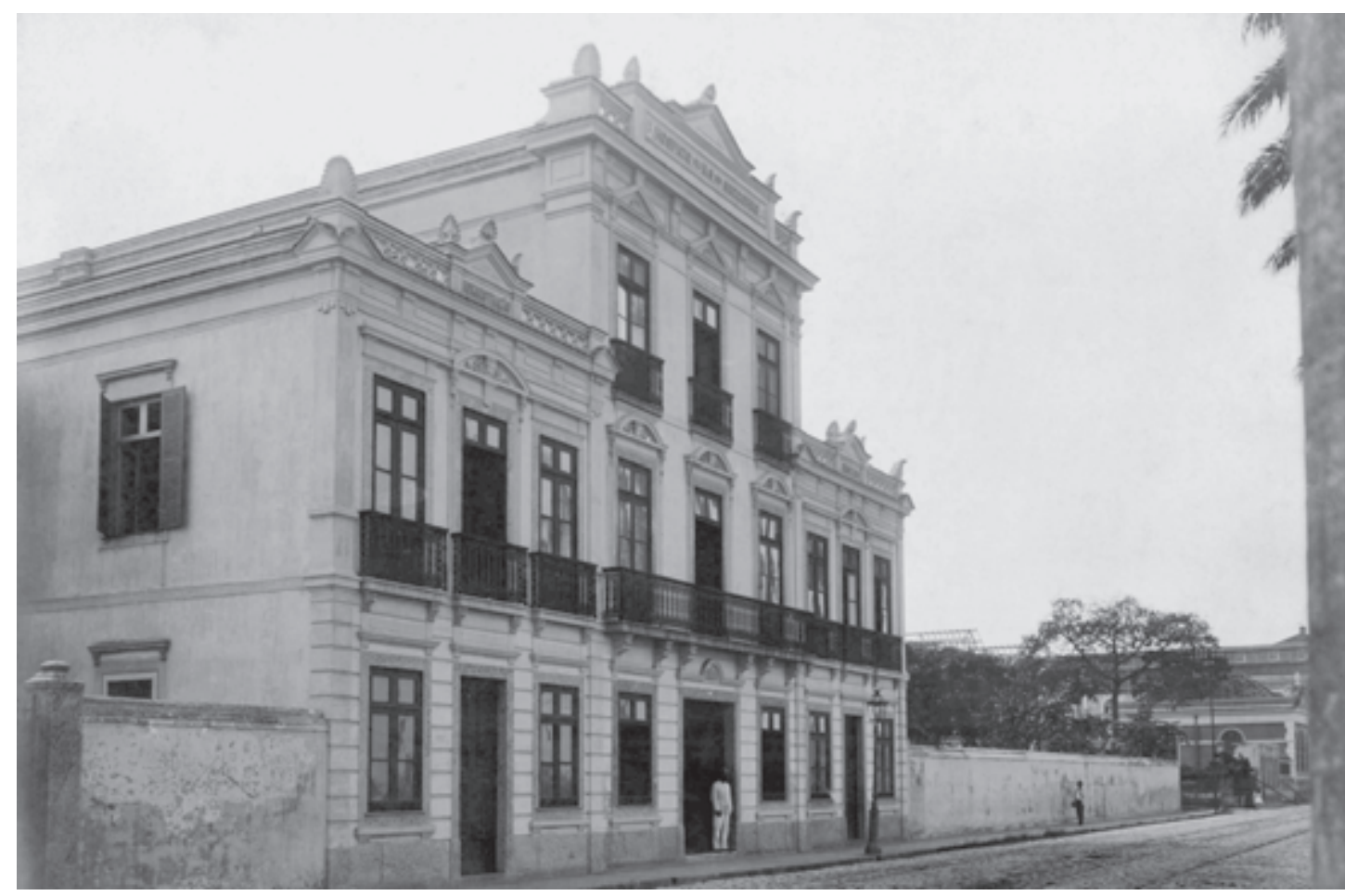



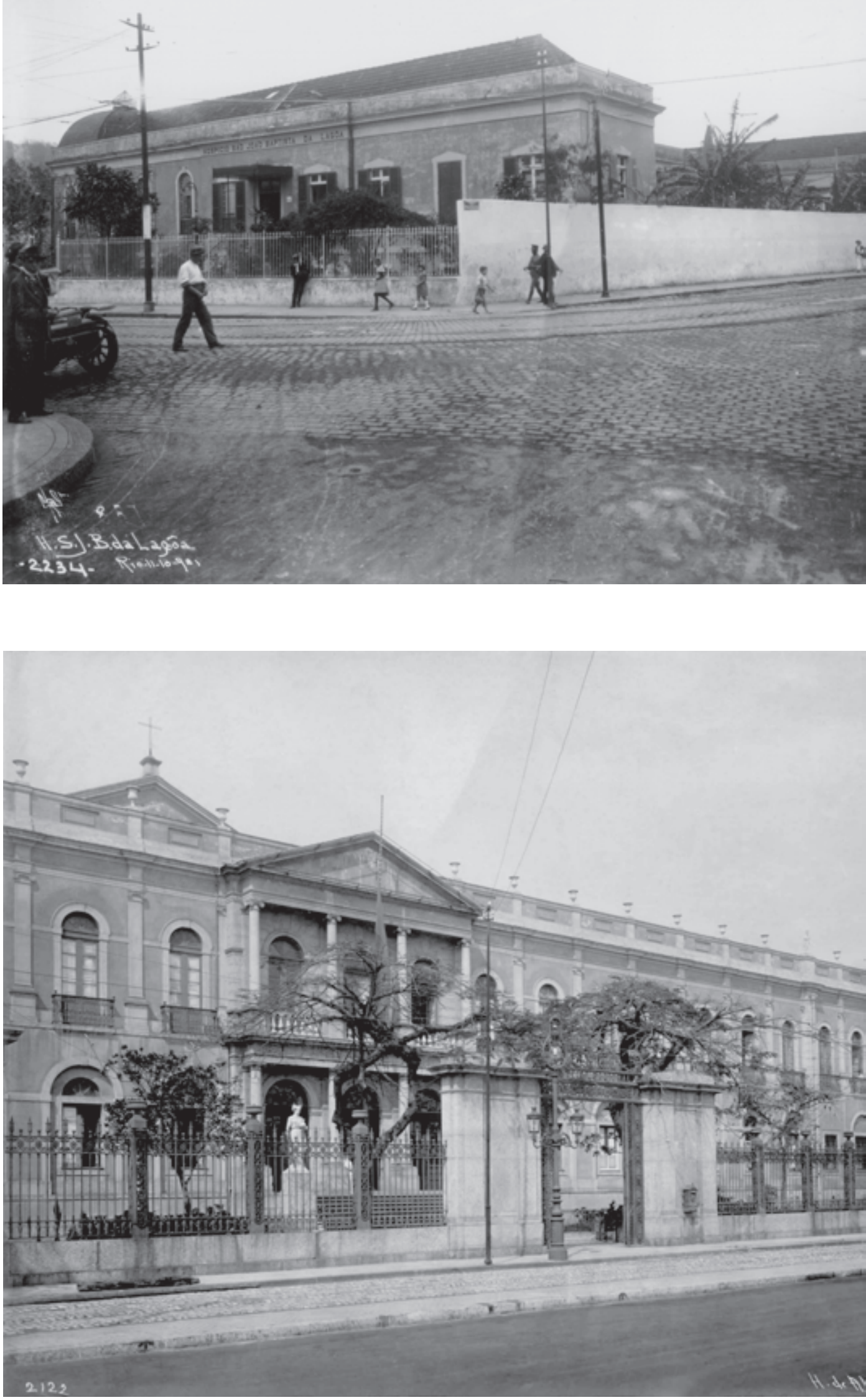

Hospício de São João Batista da Lagoa, 11 out. 1901. Foto Augusto Malta. Acervo Arquivo Geral da Cidade do Rio de Janeiro

Primeira enfermaria criada pela Irmandade da Misericórdia para responder a imposição do governo imperial, o Hospício de São João Batista da Lagoa foi inaugurado em 1852 e destinava-se a atender à população pobre das freguesias de São Botafogo e Copacabana. $\mathrm{O}$ edifício foi construído na década de 1880 e ampliado na década de 1920.

Hospício Nacional de Alienados, 1922. Foto Augusto Malta. Acervo Museu da Imagem e do Som, RJ

Sua construção foi iniciada em 1842 e inaugurada em 1852, com o nome de Hospício Pedro II. Era uma das obras de caridade da Irmandade da Misericórdia. Em 1891, depois da Proclamação da República, passou para a administração do Estado e recebeu o nome de Hospício Nacional de Alienados. Desde 1944 é o Palácio Universitário da UFRJ. 
Instituto Pasteur,

rua das Laranjeiras, [s.d.]

Criado em 1888, o

Instituto Pasteur do Rio de Janeiro tinha como função a fabricação do soro anti-rábico. Este edifício foi seu segundo endereço, na rua das Laranjeiras, em imóvel pertencente à Irmandade da Misericórdia e atualmente alugado para fins comerciais.
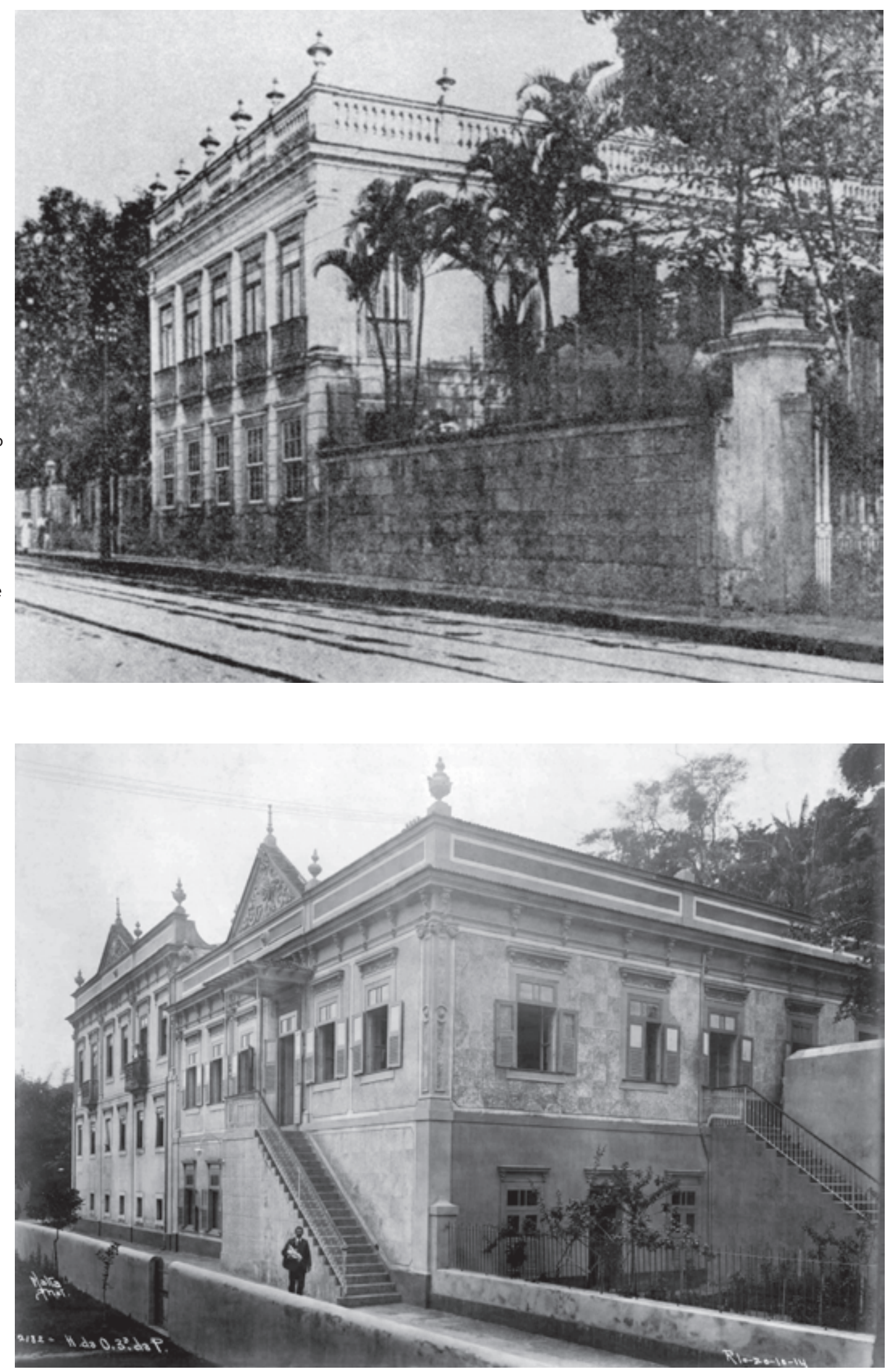

Hospital da Ordem $3^{a}$ de São Francisco da Penitência, [s.d.]. Foto Augusto Malta. Acervo Museu da Imagem e do Som, RJ

O Hospital da Ordem $3^{a}$ de São Francisco da Penitência foi instalado em 1763 no largo da Carioca, onde funcionou até 1905 , quando as obras de alargamento da rua da Carioca o condenaram. Foi nesse ano que se transferiu para três chácaras adquiridas na rua Conde de Bonfim, endereço em que se encontra ainda hoje, em prédio construído na década de 1930 . 

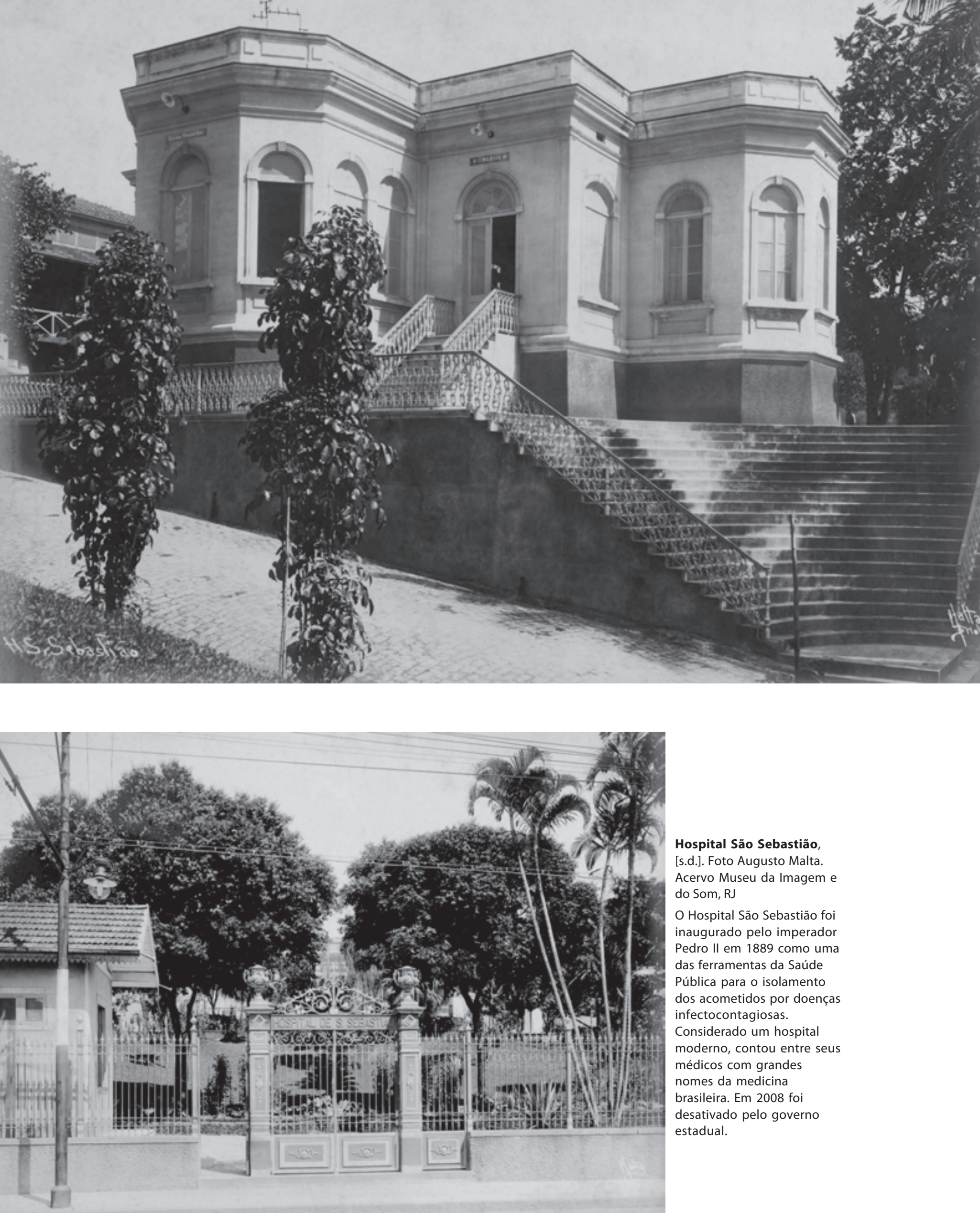

Hospital São Sebastião,

[s.d.]. Foto Augusto Malta.

Acervo Museu da Imagem e do Som, RJ

O Hospital São Sebastião foi inaugurado pelo imperador Pedro II em 1889 como uma das ferramentas da Saúde Pública para o isolamento dos acometidos por doenças infectocontagiosas. Considerado um hospital moderno, contou entre seus médicos com grandes nomes da medicina brasileira. Em 2008 foi desativado pelo governo estadual. 


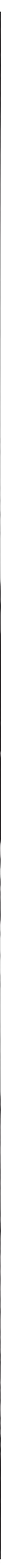

Hospital da Força Policial, [s.d.]. Foto Augusto Malta. Acervo Arquivo Geral da Cidade do Rio de Janeiro

O antigo Hospital da Brigada Policial, hoje Hospital Central da Polícia Militar, foi criado na década de 1840 e instalado, primeiramente, no Morro de Santo Antônio, tendo sofrido diversas alterações ao longo do século XIX e início do século XX. Em 1940 foi transferido para as dependências do antigo Hospital Estácio de Sá, onde permanece até hoje. 
A Saúde Pública no Rio de Janeiro Imperial

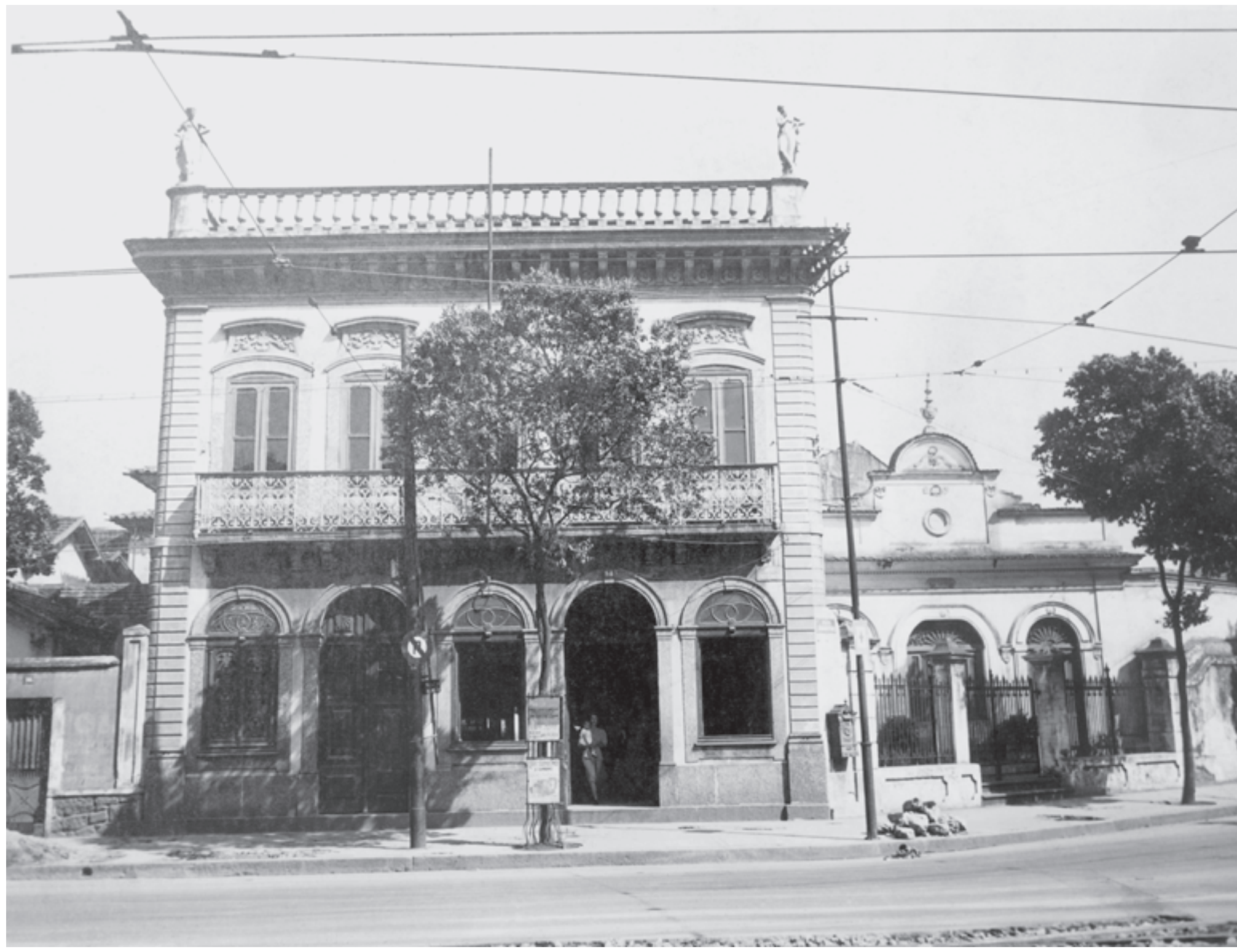

Fachada do primeiro edifício do Instituto Hahnemanniano do Brasil, [s.d.]. Acervo do Instituto Hahnemanniano do Brasil O Instituto Hahnemanniano do Brasil (IHB) assume como data de sua criação o ano de 1859 e tem como fim promover a propagação da homeopatia. O instituto sempre funcionou na rua Frei Caneca. O prédio atual data da década de 1950. 


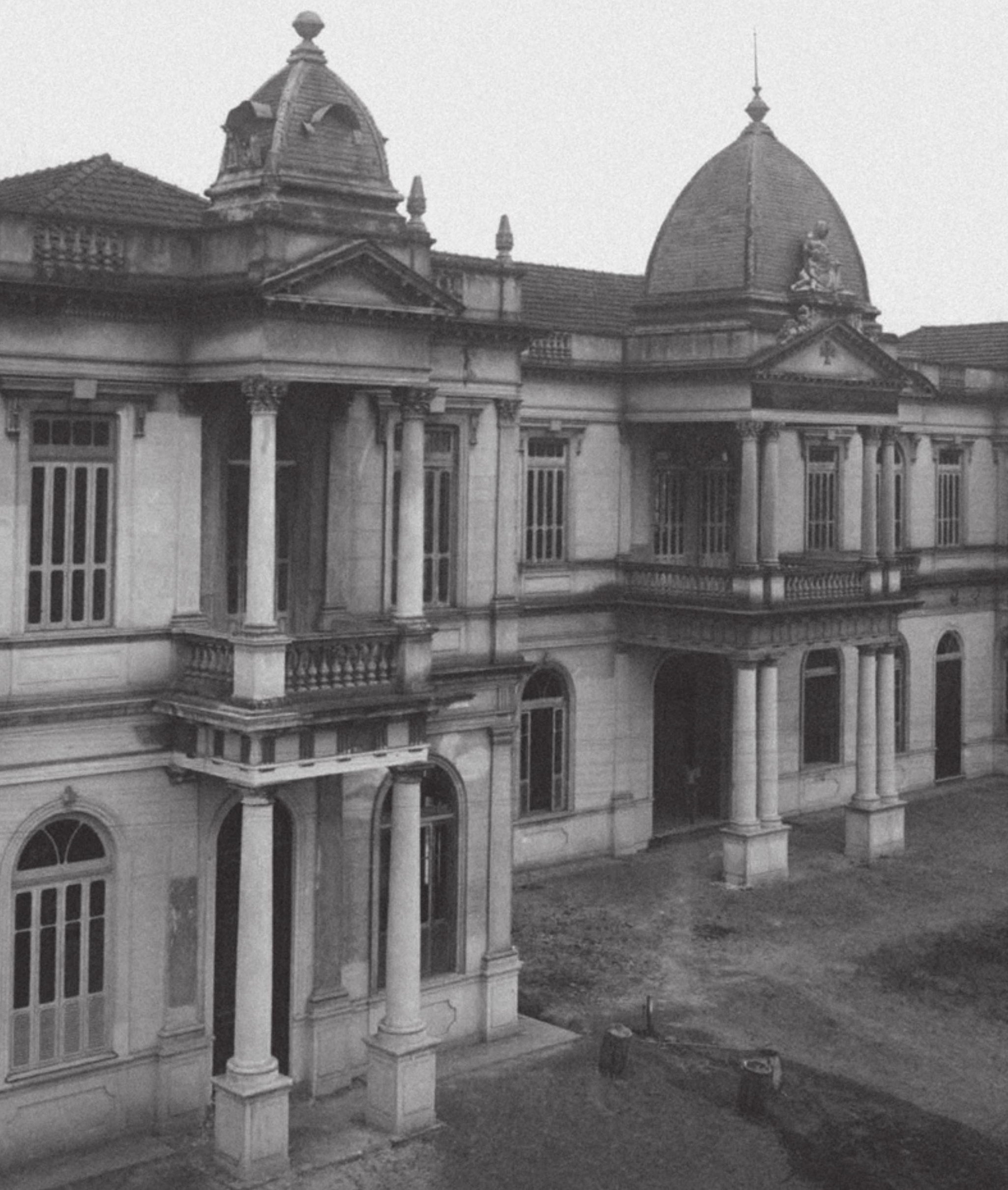


3

A Primeira República e a Constituição de
uma Rede Hospitalar no Distrito Federal

Gisele Sanglard 


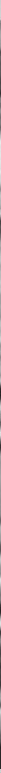


O estudo aqui apresentado remonta ao início da República, mais especificamente entre os anos 1906 e 1929, quando se percebe um evidente contraste no que concerne às atuais concepções sobre saúde, bem como à própria esfera de ação do Estado. A análise se concentrará nas idéias e propostas a respeito da constituição da rede hospitalar na cidade do Rio de Janeiro, então Distrito Federal, presentes no debate que perdurou ao longo daquele período, envolvendo médicos, higienistas e filantropos. Chama a atenção nesse debate a definição de assistência pública, a qual não possui nenhuma similaridade com o atual significado de assistência médica, embora se tratasse da prestação de certos serviços médicos à população. Entendia-se como assistência pública um vasto e abrangente leque de ações às quais se atribuía caráter público - desde os cuidados com a infância e a maternidade até aqueles com a velhice e a loucura - e que envolvia um conjunto de instituições públicas e privadas, laicas e religiosas - hospitais, asilos, orfanatos, colônias, creches, ligas, postos médicos, maternidades, hospícios, dispensários, policlínicas-, cujos limites de atuação eram tênues e permeáveis.

Quando se analisam as transformações pelas quais passou a assistência pública, com base nas discussões e nas propostas apresentadas por médicos e por representantes da elite da época, torna-se possível definir esse período como uma transição entre o Estado liberal, tal como estruturado pela Constituição de 1889, e um Estado de bem-estar social, que caracterizou a chamada Era Vargas (1930-1945), que será tratada no capítulo seguinte. Percebe-se que, naquele momento, questionamentos e incertezas cercavam o liberalismo da nascente República, e identifica-se ali o surgimento de propostas e ações que seriam implementadas durante a década de 1930 .

Este capítulo está dividido em quatro partes. Na primeira, "O hospital e seu público", discuto as transformações no hospital - de lugar da caridade a espaço da terapêutica. Esse tema está relacionado com a percepção da sociedade sobre o pobre, a quem esse espaço foi destinado ao longo dos séculos, e o surgimento do operariado, que requer uma outra estrutura de assistência. Na segunda parte, "A assistência no Brasil: primeiras organizações", procuro explicitar a característica da assistência no país, centrada nas ações pias da Irmandade da Misericórdia, e as mudanças advindas com a Proclamação da República. Na terceira parte, "Repensando a assistência pública (1900-1918)", deixo a palavra aos médicos e filantropos que apresentam seus projetos para a Assistência Pública no Distrito Federal - ainda baseada na nãointervenção do Estado. Esses homens defendiam a participação da filantropia na organização da assistência. Por fim, na última parte, "A crise de leitos e as mudanças na assistência (1918-1919)", evidencio 
a passagem do Estado liberal para o de bem-estar-social. O ano de 1922 marca o último sopro de uma assistência em moldes liberais, enquanto médicos e políticos defendem seus projetos, agora clamando pela participação na criação e gestão da rede de hospitais públicos na cidade. Período de transição, no qual a fala dos médicos deixa transparecer toda a incerteza que marca a década.

\section{O Hospital e seu Público}

O hospital é um lugar para onde se acorre em momentos de doença, para tratamento clínico e cirúrgico. Contudo, a relação dos homens com essa instituição nem sempre foi assim, tendo sofrido grandes transformações ao longo dos séculos. Os hospitais eram o lugar do pobre, aonde se ia buscar alimento para o corpo e para a alma.

Na Idade Média, os hospitais - palavra cuja etimologia está ligada ao ato de hospedar - eram abertos aos acometidos por todas as mazelas humanas: os loucos, as parturientes, os enjeitados, os velhos e os doentes. Essas instituições eram o lugar, por excelência, da caridade, mesmo que em alguns momentos de sua história tenham sido usadas para fins de manutenção da ordem pública.

Desde suas origens, pode-se caracterizar o hospital por seu aspecto notadamente religioso e de centro social para atendimento à população carente — e será difícil extrair-lhe essa marca, até porque a pobreza e o cuidado dos pobres são questões centrais do cristianismo. No início, as inquietações com a salvação e a compaixão com o enfermo motivaram grande parte das doações às instituições hospitalares. Os períodos de epidemias marcavam um aumento das contribuições, que podiam ser feitas sob a forma de legados e doações ou pelo recolhimento de esmolas. Deve-se atentar para o fato de que, naquela época, o pobre era revestido de um manto santificado, era o pobre de Deus, e ao ato de abrigá-lo era atribuído igualmente um caráter sagrado. Com o tempo, as questões ligadas ao mundo terreno passaram a predominar nas relações entre a sociedade e esses estabelecimentos, transformando-os aos poucos. A partir do século XVI, foi sobretudo um novo olhar sobre o pobre e a pobreza que alterou a feição dos hospitais. O manto santificado foi posto de lado, dando lugar à idéia de que uma aglomeração de pobres representava um perigo social em potencial.

No início do século XVIII o lixo, a sujeira, as águas paradas, a exalação de odores putrefatos passaram a ser considerados como ambientes propícios para a disseminação de doenças. Por isso, as ruas das cidades, os cemitérios e as moradias insalubres foram alvo da atenção e da ação higienista. Em diversos países constituíram-se organizações sanitárias públicas visando ao controle de epidemias e pestes, cuja atuação mais visível foi aquela voltada para tais ambientes (Bourdelais, 2001; Corbain, 1986). A essa nova situação outras seriam acrescentadas, como a preocupação com a circulação, com as cidades e com as condições de vida (alimentação, moradia etc.) e trabalho. O hospital não se manteve alheio a esse clima e tornou-se um dos focos principais do problema, tendo sido aberta uma cruzada contra a aglomeração que os caracterizava (ocupação dos leitos e enfermarias, localização das salas etc.) em prol da aeração e da insolação - dois conceitos caros aos higienistas. ${ }^{1}$ No entanto, a partir do processo de reforma, ele se converteu em uma peça essencial na política sanitária e demográfica posta em prática na Europa ao longo do século XIX, não só devido aos melhores equipamentos disponíveis, mas sobretudo em virtude da formação de seu corpo médico. Era somente no hospital e na prática cotidiana que o conhecimento médico poderia ser adquirido, o que reafirmava o seu papel de equipamento médico. 
Desde o início do século XIX, já se percebia o uso da linguagem da higiene pública entre os médicos e a elite, sobretudo ao se referirem a situações definidas como sociais e nelas intervirem; os pobres eram, para eles, o foco dos principais problemas da cidade. Contudo, nesse período, paralelamente ao processo de industrialização, um novo personagem entrou em cena: o operário. Não era mais o pobre o objeto da atenção de higienistas e filantropos, mas sim o operário e suas condições de vida e habitação. Era para ele que a Lei dos Pobres inglesa, de 1834, estava voltada; ${ }^{2}$ e diversas ações filantrópicas e legislativas foram postas em prática na França, a reboque dos movimentos sociais que singularizaram o século XIX e a gênese do pensamento socialista.

É nesse quadro que surgem os "reformadores sociais", como eles se autodenominaram - intelectuais, médicos, industriais e políticos que se propuseram a pensar um novo pacto social para a França. Contrapunham-se aos "filantropos", aos quais atribuíam uma resposta ineficaz às necessidades sociais, em um momento em que eram redefinidas as fronteiras entre as esferas pública e privada, por terem tomado como objeto de atuação o 'operário' e não mais o 'pobre', anunciando um longo debate sobre a legitimidade do papel do Estado na sociedade industrial. Esses 'reformadores' tinham por objetivo alcançar a paz social, em um momento marcado pelas agitações sociais. As ações propostas por eles estavam direcionadas para a criação de habitações salubres voltadas para o operariado, o que demonstrava uma forte influência do credo higienista, mediante a criação de uma legislação protetora e de incentivos aos círculos operários, organizados nas fábricas, objetivando também a educação cívica e o lazer (Duprat, 1993). Foram defensores das sociedades de auxílio mútuo, que visavam ao socorro em caso de doença, acidente, velhice, maternidade ou morte e eram consideradas como uma necessidade do mundo do trabalho. A mutualidade era percebida como estrutura complementar para a organização dos operários e proposta em consonância com a prática liberal então vigente (Horne, 2004).

As necessidades do 'mundo do trabalho' acabaram por trazer alterações na dinâmica da assistência, obrigando-a a se adequar à matriz da vida e da cultura modernas - a indústria e suas conseqüências: acidentes de trabalho, desemprego, más condições de habitação etc. Foi nessas circunstâncias que surgiu, no século XIX, uma outra forma de assistência: as caixas de socorro mútuo ligadas às categorias profissionais. Ao lado dos serviços hospitalares, a educação sanitária passou a fazer parte das ações das caixas de socorro, tornando-se essas instituições, nas palavras de Olivier Faure (1993: 120), "instrumentos de higienização" da saúde tanto física quanto moral do trabalhador pobre. Espaço de socialização de classes, socorros médicos, previdência e poupança, as caixas de socorros mútuos se tornaram, aos olhos da elite, o lugar por excelência para o crescimento moral das classes trabalhadoras.

Foi nesse contexto de transformações que médicos e filantropos brasileiros -mesmo que restritos ao Rio de Janeiro - conceberam a assistência no Brasil e sobre ela refletiram.

\section{A Assistência no Brasil: primeiras organizações}

A assistência no Brasil se caracterizou, desde o início da colonização, por uma dependência das ações da Irmandade da Misericórdia. A Irmandade de Nossa Senhora, Madre de Deus, Virgem Maria da Misericórdia, ou simplesmente Misericórdia, foi criada em Portugal no final do século XV sob os auspícios da rainha d. Leonor, o que lhe garantiu prestígio e proteção régia, diferenciando-a das outras confrarias 
criadas na mesma época. Suas obras (hospital, Casa da Roda, recolhimento das órfãs) eram sustentadas por esmolas, doações pias dos fiéis, legados testamentais e dotações dos governos, fosse, cada um a seu tempo, a Coroa portuguesa, o governo imperial, ou o republicano (cf. verbete do Hospital da Santa Casa da Misericórdia do Rio de Janeiro, no CD-ROM).

A concentração da assistência na Misericórdia, desde o início do século XVI, fez parte de um conjunto de ações postas em prática pela Coroa portuguesa, que "lançaram os alicerces de um sistema de apoio social, relativamente uniformizado, assente numa explícita lógica de divisão de funções, que ambicionava abranger os presos, as crianças desprotegidas, os pobres e os doentes" (Abreu, 2004: 13) Foi essa mesma 'uniformização' do sistema que se expandiu por todo império ultramarino português, onde muitas vezes as Misericórdias representavam o poder colonial, misturando-se, nas suas ações, constantemente, o público e o privado.

A Irmandade da Misericórdia assumiu, na colônia, o papel de instituição pública, não só por receber o padroado régio, mas também por duas outras razões. A primeira vincula-se diretamente à organização do Estado imperial: em 1828 este delegou às províncias e aos municípios a responsabilidade pelas ações de saúde - retomando o controle das ações após a eclosão da primeira epidemia de febre amarela na Corte, no verão de 1849-1850 -, enquanto que ao governo imperial caberia agir apenas nos tempos de epidemias, na manutenção dos hospitais de isolamento (Marítimo de Santa Isabel ${ }^{3}$ e, a partir de 1886, o Hospital São Sebastião), na saúde dos portos e na fiscalização do exercício da medicina e da farmácia.

A segunda razão está ligada, justamente, à percepção da fronteira entre o público e privado tanto no período imperial quanto na Primeira República. Apesar de estarem aparentemente atuando em campos opostos, as ações dos diferentes agentes envolvidos com a assistência eram, muitas vezes, complementares. A instituição podia ser de caráter privado, mas sua 'ação' era pública. Ou, dito de outra forma:

Distintas foram, sim, as formas de gestão das variadíssimas instituições assistenciais; as tutelas que sobre elas se exerceram; as denominações - ou os significados de denominações semelhantes -; os tempos de intervenção dos poderes institucionais. Comum foi também, muitas vezes, a interatividade, quando não a complementaridade, entre os diferentes organismos envolvidos na assistência, mesmo quando posicionados em campos opostos. (Abreu, 2004: 11)

Pública ou privada, laica ou confessional, a assistência no Rio de Janeiro, e no Brasil, era realizada por diversas instituições e denominações assistenciais, que em épocas de necessidade se voltavam para socorrer os pobres.

No que tange à assistência hospitalar propriamente dita, a cidade do Rio de Janeiro contava com um grande número de hospitais, policlínicas e casas de saúde, que por mais que reservassem leitos à filantropia, pouco alteravam no cômputo geral a disponibilidade de leitos para os desvalidos. A ausência de um hospital gerido pela municipalidade causava estranhamento aos estrangeiros que por aqui aportavam, como o caso do francês Émille Allain (1886), que visitou a cidade no final do Império, apesar de considerar que o serviço de assistência pública estava muito bem organizado, graças à ação da Santa Casa da Misericórdia.

Em 1889, o advento da República alterou sobremaneira a organização das competências municipal e federal. O que até então cabia ao poder central passou a ser exercido pela municipalidade, como explicitado anteriormente. Assim, coube ao município do Distrito Federal gerir todas as ações de higiene urbana. 
Entre as diversas medidas tomadas pela prefeitura, pode-se citar a derrubada do cortiço Cabeça-de-Porco, no Centro do Rio de Janeiro, em fevereiro de 1893 - exatamente um ano após a promulgação da lei que deu poderes à prefeitura para atuar na higiene da cidade. ${ }^{4}$ Assim, a destruição do Cabeça-de-Porco na gestão do médico e prefeito Barata Ribeiro (1892-1893) reforçou a vitória da política higienista e abriu o período de forte intervenção pela qual cidade que passaria ainda na gestão do prefeito Pereira Passos (1902-1906) - o Rio do bota-abaixo. A ação demolidora culminou com a derrubada do morro do Castelo, na gestão do prefeito Carlos Sampaio (1920-1922), visando a todas as referidas medidas de melhorias das condições higiênicas e sanitárias da cidade.

Se por um lado as medidas da prefeitura se concentraram na questão urbana, com as melhorias das condições sanitárias e seu embelezamento, por outro os primeiros anos da República pouco alteraram a estrutura da assistência hospitalar na capital. A Santa Casa da Misericórdia continuava como o único hospital destinado ao atendimento dos desvalidos, mas contava com a ajuda da Policlínica Geral do Rio de Janeiro (1881) e da Policlínica de Botafogo (1899), instituições filantrópicas que prestavam atendimento ambulatorial, clínico e cirúrgico aos indigentes.

No entanto, no início do século essa estrutura ainda não era um problema para os médicos, como expressou Luiz Barbosa (1869-1949). Para ele, a capital não carecia, em 1908, de instituições de assistência, mas sim de uma forma coerente de organização e administração. O médico explicitava, em sua obra sobre os Serviços de Assistência no Rio de Janeiro, de 1908, que a classificação das instituições entre oficiais - federais e municipais - e particulares - religiosas e civis - podia ser considerada artificial, mas era plenamente aceitável para o desenvolvimento de seu livro e, em todo o caso, todos os estabelecimentos, institutos, associações e serviços de assistência trabalhavam em prol da assistência pública na cidade (Barbosa, 1908).

Vale ressaltar que uma das principais características da $1^{a}$ República foi o federalismo, que transferia aos estados a responsabilidade pelas ações de manutenção da ordem e de proteção das populações, em contraposição à centralização do poder durante o Império. Esse federalismo era legitimado pela prática liberal que propugnava a não-intervenção do Estado, o que sustentava o mandonismo local. E no que tange à assistência, a prática liberal acabava por manter a estrutura herdada dos tempos coloniais, a cargo da Misericórdia. Assim, ao Estado caberia agir apenas em tempos de grande calamidade pública, quando a ordem estivesse em perigo, ou seja, durante as epidemias; e na fiscalização dos portos e do exercício profissional.

\section{Repensando a Assistência Pública (1900-1918)}

Os primeiros anos do século XX foram marcados pela intervenção da Prefeitura do Distrito Federal nas condições higiênicas da cidade, tendo permanecido as ações de assistência tais quais as do Império. Durante a presidência de Rodrigues Alves (1902-1906), empreenderam-se reformas modernizadoras na capital federal, em três frentes de ação que se sobrepunham: o porto, a cidade e seus problemas sanitários.

Essas três frentes voltavam-se para uma questão de ordem pública: os antigos casarões do Centro que haviam se transformado em habitações coletivas dos trabalhadores portuários. Esses prédios eram majoritariamente ocupados por negros egressos das fazendas, que afluíram à cidade após a abolição da 
escravatura em busca de trabalho e o encontraram no porto, onde a mão-de-obra era absorvida na carga e descarga de navios que aportavam em número cada vez maior. Vinham, portanto, aos olhos das autoridades, aumentar o já numeroso contingente de ex-escravos e libertos que circulavam pela cidade. Assim, os inúmeros cortiços que existiam eram considerados ameaças públicas à ordem, segurança, moralidade, salubridade, e como tais deviam ser controlados e combatidos. Parece que, aos olhos dos republicanos, o pobre se tornara perigoso, pois colocava em risco seus planos de construção de uma nação civilizada e industrial nos trópicos (Benchimol, 1992; Chalhoub, 2004).

A Reforma Sanitária configurou-se, ao mesmo tempo, como objeto de ação e justificativa para o projeto modernizador (Benchimol, 2001). Coube ao médico Oswaldo Cruz chefiar a Diretoria-Geral da Saúde Pública (DGSP), órgão que centralizou as ações de saúde pública na capital. Oswaldo Cruz foi investido de poderes de polícia que lhe permitiram invadir residências, estabelecimentos comerciais e industriais, a fim de identificar focos de epidemias, bem como de adotar as necessárias medidas profiláticas.

Uma das conseqüências dessa reforma foi a perda, por parte da Prefeitura do Distrito Federal, ${ }^{5}$ da maior parte de suas atribuições, que passaram a ser centralizadas na esfera federal, à exceção dos socorros médicos de urgência. Embora lamentando essa medida, o médico Luiz Barbosa reconhecia que, apesar da obrigação da prefeitura de 'fundar, dirigir e organizar' os postos de assistência e do seu 'dever' de prestar socorro de urgência em casos de acidentes nas ruas e nos balneários, pouca coisa havia sido realizada. Foi iniciativa da municipalidade criar, em 1903, o Ofício Geral de Assistência, que teria como objetivo organizar as diversas iniciativas filantrópicas de assistência espalhadas pela cidade, e no ano seguinte, a primeira tentativa de organização dos serviços de urgência. A primeira medida não chegou a ser implementada e a segunda, na opinião do médico, trouxe vícios antigos, notadamente porque os referidos serviços de urgência foram instalados em prédios impróprios e não contavam com material suficiente para as funções clínicas e administrativas. Contudo, a assistência de urgência tomou outros rumos com inauguração, no dia $1^{\circ}$ de novembro de 1907, do Posto Municipal de Assistência, na rua Camerino, o atual Hospital Municipal Souza Aguiar.

Paralelamente ao rearranjo das atuações e competências dos poderes municipal e federal na cidade do Rio de Janeiro, os primeiros anos do século XX viram surgir diversos congressos dedicados ao tema da assistência pública e privada, onde médicos e filantropos encontraram o palco ideal para defender suas idéias sobre o assunto. Essa discussão estava em consonância direta com as idéias debatidas em todo o mundo ocidental, quando, como já dito aqui, o papel do Estado na sociedade estava sendo discutido e questionado (Polanyi, 2000). Foi nesse contexto de rearticulação e de redefinição dos papéis sociais que se conceberam propostas para a assistência pública e privada, tema extremamente caro aos liberais. Essa discussão não ocorreu, contudo, ao mesmo tempo em todos os países, elas perpassaram todo o século XIX e início do século XX e estavam diretamente relacionadas aos momentos históricos vividos pelos Estados nacionais. ${ }^{6}$

Entre as personagens que apresentaram propostas para a organização da assistência na capital brasileira, destacaram-se os médicos Luiz Barbosa, Carlos Arthur Moncorvo de Figueiredo Filho (Moncorvo Filho), Antônio Fernandes Figueira, Garfield de Almeida e o filantropo Ataulfo Nápoles de Paiva.

Luiz Barbosa apresentou, em sua obra já citada de 1908, como deveria ser organizada a assistência pública pela prefeitura. Defendia a aplicação, na capital, de um sistema de socorro similar ao de Buenos 
Aires, em que a cidade foi dividida por distritos de atuação dos socorros e as ambulâncias seriam dirigidas por acadêmicos de medicina. A comparação entre as duas capitais sul-americanas era bem desfavorável ao Rio de Janeiro, onde o transporte de doentes e feridos se fazia em padiolas emprestadas ou em veículos da Assistência Policial e, na maior parte das vezes, sem exame médico. Barbosa sugeria um acordo com o governo federal para instalar seus postos nas delegacias de saúde e o aproveitamento das policlínicas como recurso complementar aos socorros de urgência. Vale ressaltar que Luiz Barbosa foi o criador da Policlínica de Botafogo, além de ter dirigido a Assistência Pública Municipal, no período.

Em 1907, Moncorvo Filho (1871-1944) publicou o folheto “Assistência pública no Rio de Janeiro e particularmente da Assistência à Infância", fruto de sua comunicação no IV Congresso Internacional de Assistência Pública e Privada realizado em Milão, no ano anterior, onde fez um balanço da situação da assistência no Rio de Janeiro e propôs medidas para melhor organizá-la. Afirmava que, segundo as "modernas doutrinas", cabia às municipalidades a organização dos serviços de assistência, e à União o estabelecimento de leis gerais de assistência e a organização do órgão central, que deveria presidir todo o movimento, orientando os diversos serviços, de caráter privado ou nacional.

Moncorvo descrevia brevemente a situação das instituições privadas, ${ }^{7}$ com mais ênfase na Santa Casa da Misericórdia. A esta atribuía sérios problemas, alguns considerados como "de origem" - o fato de ser uma instituição de caridade -; outros devidos aos inúmeros doentes que era obrigada a aceitar, "debaixo de seu caridoso teto", bem como aos atendimentos de emergência (acidentes de rua e outros), para os quais não estava preparada e que deveriam ser feitos pela municipalidade; ou mesmo devido à planta do prédio, considerada como obsoleta e que, por exemplo, deixava as enfermarias muito próximas umas das outras. Todos esses fatores contribuíram para que o atendimento na Santa Casa fosse deficitário. Concluiu afirmando que as lacunas deixadas no atendimento na Santa Casa eram plenamente aceitáveis em face dos inúmeros serviços e encargos que ela suportava (Moncorvo Filho, 1907).

Opinião semelhante foi expressa pelo médico Antônio Fernandes Figueira, em 1902, nas páginas do periódico Brazil-Médico. Para ele, era urgente a melhoria do serviço hospitalar na cidade no que tangia ao atendimento às crianças, à questão do isolamento e às instalações hospitalares, sobretudo ao se anexar as enfermarias aos serviços clínicos. Mesmo que houvesse movimentação de criação de hospitais pela municipalidade, ele acreditava que o mais importante era introduzir reformas "nas casas santas, a que vão ter os doentes sem recursos" (Figueira, 1902: 311-312), além de separar crianças de adultos e contar com isolamentos mais definidos a fim de não misturar variolosos com tuberculosos e pestilentos. Para Fernandes Figueira, essa era a maior obra que o provedor da Santa Casa poderia realizar.

Como se verá mais adiante, o discurso sobre a superlotação da Santa Casa da Misericórdia era uma constante na fala dos médicos, mesmo que a irmandade mantivesse diversos outros hospitais ou buscasse abrir novas instituições - como a Policlínica das Crianças e o Hospital São Zaccharias, abertos respectivamente em 1909 e 1916, ambos destinados ao atendimento da puericultura intra e extra-uterina -, para atender a uma demanda deles mesmos.

Voltando às idéias defendidas por Moncorvo Filho no congresso de 1906, ele propunha, em uma perspectiva bem próxima daquela da prática francesa - centrada na ação dos bureaux de higiene municipais (Bourdelais, 2005) -, a criação de um Conselho Superior de Assistência Pública e de um Serviço de Assistência Pública que deveria constituir um ramo autônomo da administração pública, com receita 
própria. Suas ações estariam voltadas para os socorros em domicílio e para aqueles proporcionados nos hospitais, hospícios, dispensários, policlínicas etc., sob jurisdição do Ministério da Justiça e Negócios Interiores.

No caso específico da capital federal, Moncorvo Filho defendia a criação de um Escritório Central, onde funcionaria a sede da Assistência Pública. Em cada bairro, seriam instalados escritórios de beneficência, que contariam com postos médico-cirúrgicos, aparelhados para atendimento de emergência, diurna e noturna, e dos acidentes da via pública. Os escritórios também teriam como funções organizar as listas de indigentes e necessitados da circunscrição e dar assistência em domicílio.

Como medida prática e visando ao bom funcionamento da estrutura, Moncorvo Filho previu a utilização de instituições de assistência amplamente reconhecidas como postos de assistência - as policlínicas gerais do Rio de Janeiro e de Botafogo e o Hospital da Santa Casa da Misericórdia. O Instituto de Proteção e Assistência à Infância (Ipai) ficaria reservado à assistência à infância, incluindo exame e atestação de amas-de-leite mercenárias, fornecimento de leite aos recém-nascidos pobres e a assistência em domicílio às mulheres grávidas pobres. As mulheres que não pudessem ser atendidas no Ipai seriam encaminhadas à Maternidade de Laranjeiras ou à Santa Casa. Já os tuberculosos seriam encaminhados à Liga Brasileira contra a Tuberculose.

Novamente, as policlínicas apareceram como recursos a serem somados à Assistência Pública. Vale ressaltar que, tal qual Luiz Barbosa, Moncorvo Filho era intimamente ligado ao projeto filantrópico das policlínicas, pois seu pai fora um dos fundadores da Policlínica Geral do Rio de Janeiro, e ele mesmo o criador do Ipai. Ambos os médicos apostavam fortemente na aliança entre a filantropia e a Assistência Pública, bem como na proposta de assistência defendida por essas instituições.

Em 1908, a Prefeitura do Distrito Federal, na gestão de Francisco Marcelino de Souza Aguiar (19061909), promoveu um Congresso Nacional de Assistência Pública e Privada, realizado durante a exposição comemorativa do centenário da abertura dos portos. A comissão organizadora indicada era formada pelos médicos Benjamin da Rocha Faria e Antônio Fernandes Figueira, pelo jurista e filantropo Ataulfo Nápoles de Paiva, pelo poeta Olavo Bilac, além de João Carneiro de Souza Bandeira, Alfredo da Graça Couto e José de Medeiros e Albuquerque. Foram enviados convites às sociedades científicas, às faculdades de medicina, aos hospitais públicos e privados, às sociedades de beneficência e a todas as pessoas que se preocupavam com o problema da assistência.

O congresso foi divido em quatro sessões: Assistência médica; Assistência pública em geral; Assistência à infância; Assistência externa. Entre as diversas teses defendidas no congresso e publicadas na BrazilMédico de 1908, destacam-se as de Antônio Fernandes Figueira e de Garfield de Almeida.

O relatório apresentado por Fernandes Figueira para a sessão "Assistência pública: assistência à infância e particularmente o que se refere às medidas a adotar contra a mortalidade infantil. Educação das crianças deficientes" previa as seguintes medidas: organização, por parte do poder público, de um corpo de inspetores-médicos para a fiscalização das lactantes; obrigação das instituições de assistência aceitarem como fundamento a amamentação de crianças até os seis meses de vida; extinção das 'rodas', ${ }^{8}$ substituídas pelos 'registros livres'; urgência de fundação de sociedades de assistência em domicílio às puérperas e de proteção à amamentação materna; a criação do maior número possível de 'consultórios de lactantes' nas cidades e aldeias; a fiscalização, por parte do poder público, do leite destinado ao consumo das crianças (Figueira, 1908). 
Garfield de Almeida (1908), por sua vez, criticava os serviços hospitalares oferecidos na capital, além de reforçar o discurso que reafirmava o atraso do Rio de Janeiro no concernente à assistência pública. Suas conclusões indicavam o caminho para solucionar os problemas: a construção, com urgência, de um hospital público, que deveria ser instalado em terreno devoluto, em especial aproveitando um dos pavilhões da própria exposição de 1908. O sistema adotado seria o pavilhonar, com quarenta leitos em cada pavilhão, totalizando 14 pavilhões e 540 leitos, separando os doentes pelos 'três' (sic) sexos (homens, mulheres e crianças). O hospital contaria com um pavilhão menor, de observação; um pavilhão de enfermaria dupla, com quarenta leitos, para tuberculosos; um pavilhão de convalescentes, além de ambulatório com dez serviços. Outro ponto capital para ele era a ampliação do Asilo São Francisco de Assis, que seria melhor aproveitado se transformado em hospital-asilo.

O jurista Ataulfo de Paiva defendeu, por sua vez, a proposta de criação de um Ofício Central de Assistência, privado, constituído pela representação das instituições privadas. Seu projeto tinha por objetivo organizar a ação direta do poder público na execução e fornecimento de proteção à indigência em geral. Propunha a criação de uma Diretoria-Geral de Assistência Pública, sob cuja responsabilidade ficariam os serviços de socorros do governo (Paiva, 1916).

O Ofício Central de Assistência, organizado pelo poder central, teria como objetivo congregar e harmonizar os interesses da assistência pública e privada quando exercendo suas atividades gratuitamente. Esse órgão deveria preservar a autonomia e a administração das associações, casas pias, asilos, sociedades e outras instituições que exerciam a assistência privada. Somente dessa forma estaria o poder público habilitado para encaminhar e resolver "as grandes e capitais questões que afeta[va]m o exercício da assistência em geral" (Paiva, 1916: 321).

As conclusões gerais do congresso, no que tangia à assistência de urgência e à hospitalar, nos ajudam a entender as discussões que ganharam a agenda de médicos e filantropos. Quanto à primeira, os congressistas decidiram que era de competência do poder municipal, que todas as cidades com população numerosa ou industrializada deveriam ter um serviço de urgência e que o Posto Central de Assistência do Rio de Janeiro seria considerado como modelo a ser aplicado em outras cidades. Contudo, os serviços de emergência no Rio de Janeiro ainda estavam restritos aos locais onde poderiam atender com presteza, e era necessária a criação de outros postos de emergência nos distritos sanitários municipais urbanos. O congresso reafirmou a centralização das ações proposta pela Reforma da Saúde Pública de 1904, ao mesmo tempo que elogiou os trabalhos realizados pela Prefeitura do Distrito Federal em prol da assistência de urgência, mesmo que esta ainda tivesse que melhorar um pouco.

Já no que diz respeito à assistência hospitalar, o congresso concluiu que era urgente a construção de um hospital pela municipalidade do Rio de Janeiro; que eram imprescindíveis a ampliação do Asilo São Francisco de Assis e a criação de um hospital-asilo para incuráveis com capacidade de duzentos leitos, cem para cada sexo. Com isso, entrou em cena um pleito que dominou boa parte das discussões sobre a assistência nas décadas seguintes: a construção de hospitais públicos na capital federal. Esse tema tornouse ainda mais palpitante a partir de 1918, com a chegada da epidemia de gripe espanhola, que demonstrou a ineficiência dos serviços de assistência na capital.

Oito anos depois desse congresso, Ataulfo de Paiva publicou o livro Justiça e Assistência, no qual reuniu diversos artigos de sua autoria sobre temas ligados à justiça e à assistência, dissertando também 
sobre o tema do mutualismo e da assistência social, além de apresentar o prefácio por ele escrito para sua obra Assistência Pública e Privada no Rio de Janeiro, que só foi publicada em 1922, no âmbito das comemorações do centenário da Independência. Seu trabalho à frente da Liga Brasileira contra a Tuberculose o credenciou a participar de todos os congressos sobre o tema da assistência, tornando-o uma referência no assunto. Nesse livro o jurista e filantropo reafirmava seu projeto defendido no Congresso Nacional de Assistência Pública e Privada, de 1908, ao retomar os alicerces de sua concepção de assistência, fortemente inspirada na experiência francesa. O modelo francês era baseado no papel das comunas, dos departamentos e da nação na organização dos serviços de assistência; na França, a filantropia exerceu papel importante na assistência, sobretudo pela presença de inúmeros filantropos que defendiam seus ideais na Assembléia Constituinte (Faure, 1993).

Nesse prefácio, Ataulfo de Paiva fazia uma radiografia da assistência pública no Brasil, ao mesmo tempo que apresentava suas bases constituintes. ${ }^{9}$ Entre esses itens vale ressaltar que, no que tange à puericultura, Paiva defendeu as idéias propostas por Moncorvo Filho; para as mulheres a questão da assistência estava diretamente relacionada à força de trabalho e às condições de cuidado dos filhos, e assistência social seria traduzida na criação de maternidades, que salvariam o filho e a mãe.

No que se refere à assistência hospitalar, sua análise estava também baseada na experiência francesa, centrada nas associações de caridade e nas sociedades filantrópicas, e nas discussões que lá ocorreram desde o final do século XVIII e atravessaram o século XIX (Duprat, 1993, 1996; Faure, 1993; Sanglard, 2008). Tais associações e sociedades, além de distribuírem o pão, o vinho e o agasalho, também faziam visitas domiciliárias e atendimentos médicos. Sobre o hospital propriamente dito, além de ter discorrido sobre as mudanças na arquitetura hospitalar, desde Tenon, ${ }^{10}$ e ressaltado o modelo do hospital francês de Lariboisière, Ataulfo de Paiva falou do esgotamento do Hospital da Misericórdia do Rio de Janeiro e da necessidade de se construir um hospital público na capital; recuperou a fala de Garfield de Almeida no congresso de 1908, afirmando que, segundo os cálculos do médico, o hospital-modelo, aqui, deveria contar com oitocentos leitos. Por fim, encerrou a sessão com uma frase que resumia a expectativa da época em torno da construção de um hospital público no Rio de Janeiro: "Desta empresa, porém, e até esta data, ainda não se cogitou nas esferas governamentais. Nem tão cedo virá ela preencher mais uma das grandes e notáveis lacunas da assistência pública e privada no Rio de Janeiro" (Paiva, 1916: 219).

\section{A Crise de Leitos e as Mudanças na Assistência (1918-1929)}

O período entre 1917 e 1918 foi marcado por dois fatores que acabaram por influenciar e redirecionar os debates acerca da assistência de modo geral e, em específico, hospitalar: a eclosão das greves operárias no Rio de Janeiro e em São Paulo, que levaram à Câmara dos Deputados a discussão sobre o trabalho feminino e infantil, os acidentes de trabalho e a proteção social (Gomes, 1979), e a pandemia de gripe espanhola, no verão de 1918-1919, que chamou a atenção para um problema crônico dos grandes centros urbanos: a deficiência de centros de socorro à população carente. Como Ataulfo de Paiva vaticinara, nenhum movimento por parte da municipalidade ou do governo federal havia sido realizado com vista ao aumento de leitos hospitalares. 
A 'espanhola' transformou a questão da assistência hospitalar em uma das bandeiras da gestão de Carlos Chagas (1919-1926) à frente do recém-criado Departamento Nacional de Saúde Pública (DNSP). ${ }^{11}$ Nesse período foram criados diversos hospitais no Rio de Janeiro, como o Hospital Pedro II (1920), o Hospital São Francisco de Assis (1922), o Hospital Gaffrée \& Guinle (1924-1929) e o Abrigo-Hospital Arthur Bernardes (1924), e iniciadas as obras do Hospital do Câncer (1927-1935) e do Hospital de Clínicas Arthur Bernardes da Faculdade de Medicina (1926-1934), que mudariam a cara da assistência pública no Rio de Janeiro, sem contar a criação das colônias Juliano Moreira (1924) e Curupaity (1922-1928). Esses hospitais eram todos subvencionados pelo DNSP e vinculados à política de Carlos Chagas; dois deles foram construídos às expensas da filantropia da família Guinle ${ }^{12}$ (Sanglard, 2008).

O debate acerca da carência de leitos na cidade ocupou amplo espaço na imprensa cotidiana. Um dos médicos mais presentes foi José de Mendonça, que teve no Correio da Manhã o espaço, por excelência, de divulgação de suas idéias. Em 1918, logo após a chegada da 'espanhola', Mendonça propôs a construção de quatro hospitais de mil leitos cada um, nas regiões de Botafogo (próximo à faculdade), Andaraí, São Cristóvão (na parte litorânea do bairro, para socorrer os marítimos) e Méier ou Cascadura (próximo à linha da Estrada de Ferro Central do Brasil). Defendia a tese, que foi encampada por outros médicos, de que a assistência hospitalar não devia ser gratuita, mas proporcional ao que cada doente pudesse pagar; no caso de incapacidade total, caberia à municipalidade arcar com os custos.

Nesse mesmo ano, Carlos Chagas afirmou, durante homenagem aos médicos baianos no Derby Clube do Rio de Janeiro, que o Brasil precisava de novos e modernos hospitais, para atender às "nosologias habituais" e, eventualmente, às epidemias. Em seu discurso reiterou que o Hospital da Misericórdia não tinha mais condições de se expandir para atender às necessidades da assistência pública (Chagas, 1919).

Em 1920, uma proposta parecida seria defendida na Câmara dos Deputados, pelo médico gaúcho Domingos Mascarenhas, que conseguiu transformar em decreto seu projeto para a construção de três hospitais no Distrito Federal, um dos quais próximo à Faculdade de Medicina, todos com capacidade superior a mil leitos e administrados pelo DNSP e seguindo o modelo alemão de arquitetura hospitalar. Nesse projeto, a gratuidade estava garantida aos indigentes, os outros pagariam proporcionalmente às suas condições financeiras. Esse projeto foi fortemente inspirado nas idéias de José de Mendonça (Brasil, 1920) e amplamente discutido e debatido na Câmara dos Deputados com a presença dos médicos-deputados Palmeira Ripper, Zoroastro Alvarenga, Domingos Mascarenhas, Alexandrino Rocha, Raul Barroso, Dionysio Bentes, Rodrigues Lima e Teixeira Brandão, e contou com a participação de Carlos Chagas e Luiz Barbosa. Contudo, a proximidade das comemorações do centenário da Independência impediu que o Projeto Mascarenhas, como ficou conhecido, pudesse ser implantado, o que concorreu para o acirramento das críticas (Brasil, 1923). O projeto foi reeditado mais duas vezes, com alterações, sem que jamais tenha sido executado.

Das discussões acerca desse projeto vale a pena ressaltar algumas falas. Carlos Chagas, que argumentou que havia mais de cinqüenta anos não se fazia qualquer melhoramento na assistência hospitalar, apesar do aumento sempre crescente da população e, conseqüentemente, dos enfermos que a ela apelam, para reiterar a situação limite por que passavam a Santa Casa e o Hospital São Sebastião. Teixeira Brandão ressaltou a urgência de um hospital para o ensino das clínicas para a Faculdade de Medicina e defendeu a construção de hospitais para os funcionários municipais, o que descongestionaria a assistência hospitalar federal, e a criação de assistência domiciliária. Já Domingos Mascarenhas fez uma comparação negativa 
entre o Rio de Janeiro e Buenos Aires (Mendonça, 1920), tema recorrente entre médicos e intelectuais da época (Sanglard, 2007).

No âmbito das comemorações do centenário da Independência, dois eventos chamaram atenção para a questão da assistência pública na cidade. O primeiro foi a, já mencionada, publicação pela prefeitura da obra Assistência Pública e Privada no Rio de Janeiro (1922), que apresentava o histórico e as estatísticas de todas as instituições e associações existentes que prestavam assistência pública, assim como aquelas previstas, como o Hospital Gaffrée \& Guinle. O segundo foi a realização do Congresso Nacional dos Práticos, ocorrido na Policlínica Geral, que teve umas de suas sessões dedicada ao tema da assistência pública. Entre as diversas comunicações do congresso, vale ressaltar: "A verdadeira organização hospitalar e sua estrutura administrativa", "Autonomia dos hospitais; médicos e enfermeiros", "O hospital como meio de instrução prática", com relatoria de Irineu Malagueta; "Reflexões sobre a assistência hospitalar", por José de Mendonça; “Assistência pública e privada: relação e regulamentação”, por Moncorvo Filho; "O abuso da hospitalização gratuita, a verificação da indigência, e as tarifas hospitalares módicas", por Miguel Couto, e "A assistência hospitalar é dever das municipalidades", por Luiz Barbosa.

Os relatórios apresentados recuperavam muitas das discussões que atravessaram as décadas anteriores, contando com a presença das mesmas personagens e abrindo espaço para novas propostas. José de Mendonça, um dos grandes defensores da criação de hospitais públicos na cidade, usou seu espaço para conclamar ao apoio ao projeto do deputado Amaral Carvalho, de 1921, que recuperava em sua quase totalidade o Projeto Mascarenhas - à exceção do modelo arquitetônico adotado, que passava a ser o monobloco, e do nome do Hospital de Clínicas, que seria Pedro II, em homenagem ao imperador (Brasil, 1921). Outros, como Irineu Malagueta, trouxeram novamente à tona a discussão sobre a quem deveria caber a construção dos hospitais: à municipalidade ou à federação? Para Luiz Barbosa esta seria uma função do município... Miguel Couto lançou o debate público sobre a questão da gratuidade nos serviços. Foi aplaudido por José de Mendonça no que tangia à defesa da abertura de hospitais, e criticado com relação à inobservância da verificação da indigência, considerada por ele como necessária. Esse ponto levou Luiz Barbosa a defender a verificação pela prefeitura, no serviço de assistência. Já Álvaro Ozório considerou "defeituosa a socialização" dos serviços de assistência e defendeu como indispensável a criação de um seguro obrigatório contra a doença (Actas e Trabalhos, 1923).

Em 1924 José Mendonça publicou na Revista do Brasil de 1924 um artigo, posteriormente transcrito na revista Brazil-Médico do mesmo ano, no qual reiterava a proposta de construção de quatro hospitais, de mil leitos cada um. ${ }^{13}$ A concepção de organização hospitalar desse médico era fortemente inspirada na experiência austríaca. Assim, para Mendonça, nas cidades, onde os terrenos eram mais caros, deveriam se localizar hospitais destinados a atender as vítimas de acidentes (de rua e de trabalho), os prontossocorros; para os doentes "curáveis" (internações curtas), as policlínicas; e para as parturientes, as maternidades. Já no campo, onde os terrenos eram mais baratos, deveriam instalar-se as casas de convalescentes, os sanatórios para tuberculosos, os hospitais de alienados e os sanatórios para "nervosos e viciados", segundo os termos do autor. Com relação à gratuidade, propunha que fosse regulamentada uma lei que obrigasse as empresas (estatais, industriais, comerciais ou rurais) a contribuir com valores proporcionais ao número de empregados que tivessem (Mendonça, 1924). 
Nesse cenário sobressaiu o projeto de criação dos cinco hospitais na década de 1920, dois dos quais o Hospital Gaffrée \& Guinle e o Hospital do Câncer - construídos graças à ação filantrópica de Guilherme Guinle (1882-1960), empreendimentos diretamente vinculadas ao projeto de Carlos Chagas e dos médicos ligados à Inspetoria da Lepra e das Doenças Venéreas.

Os projetos do Hospital Gaffrée \& Guinle e do Hospital do Câncer tornaram-se relevantes por terem sido empreendidos em virtude da benemerência do industrial carioca Guilherme Guinle. À época, a participação da elite brasileira na construção/manutenção de hospitais/dispensários era considerada inexistente por seus contemporâneos, a ponto de a atitude de Guinle ser interpretada como "exemplar" (Sanglard, 2008). Essa exemplaridade tão divulgada na época vem corroborar as palavras de José Mendonça (1924): o médico, tempos antes, afirmara serem raras as fortunas individuais, o que inviabilizaria a participação destas em ações filantrópicas e, conseqüentemente, transformaria o governo no único agente capaz de empreender obras de tal magnitude.

Junto com esses projetos houve também a criação, em 1924, do Abrigo-Hospital Arthur Bernardes, no bairro de Botafogo, destinado à clínica e à cirurgia pediátricas e vinculado às ações da Inspetoria de Higiene Infantil, a cargo do médico Antônio Fernandes Figueira. No projeto original previa-se, além da assistência às crianças, a instalação da Maternidade da Faculdade de Medicina (Livro de ofícios, 10 jul. 1923).

Durante a presidência de Washington Luiz, foi indicativa de mudança na política pública voltada para a assistência hospitalar a criação, em 1926, da Assistência Hospitalar, órgão autônomo em relação ao DNSP, o qual tinha por incumbência a gestão dos hospitais São Francisco de Assis e Pedro II, bem como a fiscalização dos demais estabelecimentos hospitalares da capital (Brasil, 1930). A direção da Assistência Hospitalar foi entregue a João Marinho, professor da Faculdade de Medicina. O órgão contava com um conselho hospitalar, formado por Ataulfo de Paiva, Carlos Chagas, Guilherme Guinle, Clementino Fraga, Abreu Fialho e Miguel de Carvalho. Cabia a estes o assessoramento ao diretor no projeto mais ambicioso do órgão: a construção de um hospital - Hospital de Clínicas Arthur Bernardes para a Faculdade de Medicina, com capacidade para atender 1.800 pessoas (Sanglard, 2007). A construção desse hospital atendia a duplo objetivo: dotar de hospital próprio a Faculdade de Medicina do Rio de Janeiro e aumentar a disponibilidade de leitos para a cidade. Esse projeto sistematizava todos os outros que circularam ao longo dos 25 anos anteriores.

O terreno escolhido, na região da Mangueira, foi desapropriado em janeiro de 1926. Um dos atrativos da área, e uma das justificativas apresentadas para a sua escolha, era o fácil acesso da população carente, sobretudo a dos subúrbios - localizava-se na estação da Mangueira, em proximidade com a Estrada de Ferro Central do Brasil e com a Leopoldina Railway, e ao alcance de bondes e automóveis (Brasil, 1956).

Considerado pela imprensa carioca ora como um "Notável Empreendimento", ora como "iniciativa de última hora", o projeto desse hospital teve sua gestão marcada por uma série de divergências. O projeto arquitetônico já estava escolhido quando João Marinho assumiu a direção do órgão. Fora encomendado a Porto d'Ave - mesmo arquiteto responsável pelos projetos dos hospitais Gaffrée \& Guinle e do Câncer - logo após a escolha do terreno; sua pedra fundamental foi lançada a 19 de junho de 1926 (Notável empreendimento, 1926).

Para a confecção do projeto arquitetônico, Porto d'Ave contou com o assessoramento dos professores catedráticos da Faculdade de Medicina. O responsável técnico era o professor Rocha Vaz, então diretor 
da faculdade. De acordo com o plano apresentado por Rocha Vaz ao governo em junho de 1926, o Hospital de Clínicas seria construído segundo a técnica alemã, pavilhonar, mas guardaria a organização interna americana, o que diferia das últimas propostas, conforme já comentado.

Não foi fácil encontrar o consenso entre os professores da faculdade, a Assistência Hospitalar e Porto d'Ave com relação ao projeto do hospital, e eram notórias as disputas travadas entre João Marinho e Porto d'Ave, além das várias discussões entre os professores da Faculdade de Medicina - explicitadas tanto em periódicos médicos como a Folha Médica, órgão oficial da Sociedade de Medicina e Cirurgia do Rio de Janeiro, quanto na imprensa cotidiana em geral.

Entre os pontos de discórdia estava a alegada proximidade com uma grande área populosa. Contudo, vários críticos gostariam que o novo hospital fosse localizado mais próximo ao prédio da faculdade, na Praia Vermelha, a fim de facilitar a locomoção de alunos e professores; para outros, a localização deveria ser próxima ao Hospital São Francisco, o que reunia as vantagens de estar próxima ao centro da cidade e de transformar a região do Mangue em um grande pólo de saúde - ali, também, já se encontrava instalada a Faculdade de Enfermeiras Anna Nery. Este último grupo pleiteava também a construção de um novo prédio para a faculdade na região.

O certo é que em 1931 as obras do hospital foram embargadas pelo presidente Getulio Vargas e submetidas a sindicância interna. A imprensa da época, que tanto publicara críticas, elogios ou incentivos quando as obras pareciam quase paradas, não perdeu a esperança de ver edificado o projeto, mesmo quando publicou as razões alegadas pelo diretor da Assistência Hospitalar, o médico Pedro Ernesto, para solicitar o embargo da construção: os gastos desmesurados e sem controle. Em 1934 as obras do hospital foram abandonadas em definitivo. Com o passar do tempo seu esqueleto foi ocupado - originando a favela do Esqueleto -, e nos anos 70 foi ali instalada a Universidade do Estado do Rio de Janeiro.

Assim, a década de 1920 terminou sem que um dos maiores problemas da Assistência Pública tivesse sido resolvido.

\section{O Legado dos Anos 1920: assistência à saúde entre a filantropia e a ação do Estado}

O advento da República, em 1889, trouxe mudanças no campo da assistência pública e, também, um rearranjo de forças que marcou todo o período aqui abordado. Se nos primeiros anos o problema do saneamento da cidade dominou a agenda política, no segundo momento a questão da organização da assistência passou a ganhar espaço nas preocupações de médicos e filantropos.

Um dos questionamentos que perpassam todo o período diz respeito à 'competência' das ações de saúde no Distrito Federal. O ponto nevrálgico dessa discussão era a construção de hospitais "oficiais". A quem caberia a incumbência: à prefeitura ou à União? Essa pergunta atravessou todo o período, sem uma resposta definida.

É certo que a percepção dos envolvidos nas discussões foi mudando ao longo do tempo aqui delimitado. Em 1902 não se cogitava a construção de hospitais por parte dos poderes públicos. A maioria dos presentes no Congresso Nacional de Assistência Pública e Privada, em 1908, apostava que a melhor saída para a assistência pública era a união de esforços com a assistência privada - aquela que exercia uma atividade pública. Em 1916 essa idéia ainda era válida, como bem alertou Ataulfo de Paiva. Essa união 
não eliminava, contudo, a necessidade de construção de hospitais, ditos oficiais, porém apoiava-se bastante nas ações das instituições filantrópicas, notadamente as policlínicas Geral do Rio de Janeiro e de Botafogo, e o Ipai.

Esse período também foi fortemente marcado pela defesa da assistência à mulher e da assistência à infância, vinculada a uma grande preocupação com o futuro da nação, na medida em que as crianças eram consideradas como tal. As instituições voltadas para as mulheres, por sua vez, apresentavam uma preocupação com a mãe-mulher, sobretudo com as operárias, e os meios de lhes garantir condições de cuidar de seus filhos e retornar ao trabalho. Em ambas as formas de assistência o puerpério e a puericultura estavam intimamente ligados.

Foi com esses princípios que se criaram diversas instituições filantrópicas voltadas para esse público: o já citado Ipai, instituição filantrópica voltada para as campanhas de educação e assistência maternoinfantil, fortemente inspirada em organizações francesas como as Gouttes de Lait; a Policlínica das Crianças (1909) e o Hospital São Zaccharias (1916), ambos criados e mantidos pela Santa Casa da Misericórdia e destinados, respectivamente, às crianças das zonas Norte e Sul da cidade, e com objetivos muito semelhantes aos do Ipai; e a Pro Matre (1918), maternidade filantrópica voltada para a mulher pobre. Em todas essas instituições, médicos e filantropos se uniram em prol da assistência à mulher e à criança. No mesmo período também foi criada a Maternidade de Laranjeiras, inicialmente como instituição privada, com atuação filantrópica, e depois como instituição semi-oficial, ao se tornar MaternidadeEscola da Faculdade de Medicina, em 1918.

Outro ponto a ser observado é que muitas dessas instituições voltadas para o atendimento da mãe e da criança se localizavam nos subúrbios da cidade, onde, seguindo a expansão da urbe, vivia a população operária. Foi nos subúrbios do Rio de Janeiro que se instalaram as instituições filantrópicas, mantidas por personagens de importância no meio político e industrial carioca e por associações benevolentes. Bairros como São Cristóvão e Cascadura foram objeto da atenção desses filantropos.

A partir de 1918 o discurso mudou. Não era mais o encontro da filantropia com as políticas públicas que estava sendo defendido e difundido pelos médicos, mas sim a criação e a construção de hospitais pelo poder público, pela União. Carlos Chagas deixou isso claro no discurso já citado de 1918, assim como os diversos artigos publicados por José de Mendonça sobre o tema e as discussões na Câmara dos Deputados acerca da construção de hospitais no Rio de Janeiro. Sobretudo notou-se uma união maior dos médicos em torno da questão e que a atuação da União na abertura de hospitais não devia restringirse ao Distrito Federal. Este último ponto pode ser verificado no Congresso de Práticos de 1922 e mesmo no discurso do médico e deputado Antônio Austregésilo (Actas e Trabalhos, 1923; Brasil, 1923).

Contudo, a transformação dos pleitos em realidade foi bem mais difícil. Carlos Chagas, como diretor do DNSP, esteve à frente da criação de seis hospitais e duas colônias: três adaptados em prédios já existentes (Pedro II, 1920, São Francisco de Assis, 1922, e Abrigo-Hospital Arthur Bernardes, 1924); dois construídos graças à benemerência da família Guinle (Gaffrée \& Guinle, 1924-1929, e do Câncer, inacabado); o Hospital das Clínicas da Faculdade de Medicina (mal começado) e as colônias Juliano Moreira (1924), para alienados, e de Curupaity (1922-1928), para leprosos. Desses, cinco estavam diretamente vinculados às políticas públicas postas em prática naquele momento: o Abrigo-Hospital, vinculado à Inspetoria de Higiene Infantil; os dois financiados pelos Guinle e a Colônia de Curupaity, 
subordinados à Inspetoria de Profilaxia da Lepra e das Doenças Venéreas; e a Colônia Juliano Moreira, para o atendimento de psicopatas.

Não resta dúvida de que na década de 1920 houve um avanço na organização da assistência pública na capital federal, mas apesar de os discursos chamarem o governo à responsabilidade pela assistência hospitalar na cidade, o recurso à filantropia se mostrou a solução viável e ideal para a expansão dos socorros médicos. O período foi também marcado pelo surgimento de diversos hospitais vinculados às sociedades beneficentes (Hospital Evangélico, Beneficência Espanhola, Hospital Albert Sabin e Amparo Feminino) que, ao atenderem gratuitamente os seus sócios, exerciam uma função pública, concorrendo assim para desonerar as enfermarias da Santa Casa. E viu surgirem medidas visando à criação de uma previdência social no Brasil, como resposta às greves operárias ocorridas em 1917 e 1918, no Rio de Janeiro e em São Paulo (Oliveira \& Teixeira, 1986). A preocupação com a saúde do trabalhador começou a se fazer presente nos discursos dos médicos, nas propostas, entre outras, de custeio da hospitalização dos operários, nos hospitais públicos, por parte das empresas (Mendonça, 1924).

Por fim, no período aqui abordado é de se notar a mudança ocorrida no discurso dos médicos: a publicação da obra Assistência Pública e Privada no Rio de Janeiro (1922) foi o último libelo sobre um padrão de assistência liberal. Desde o início da década, e cada vez mais, clamava-se pela presença do Estado na solução e direção da assistência no Rio de Janeiro. Contudo, o governo ainda usou a filantropia como recurso para a organização da assistência hospitalar, mesmo que, no caso das ações de Guilherme Guinle na saúde, ela representasse, antes de tudo, um apoio e um investimento na política de Carlos Chagas, na medida em que a família Guinle financiou os projetos da Inspetoria de Profilaxia da Lepra e das Doenças Venéreas, onde a manutenção dos hospitais estava a cargo do DNSP.

Foi apenas na década de 1930 que a construção e a manutenção de hospitais por toda a cidade se tornaram uma política de Estado, implementada por duas esferas de poder: a municipal e a federal. Mas tratava-se de uma outra conjuntura política.

\footnotetext{
Notas

${ }^{1}$ Em um tempo em que os preceitos de higiene ganhavam força, a intervenção das autoridades passou a ter papel decisivo, sobretudo nos locais conhecidos como focos privilegiados da doença: prisões, portos, barcos e hospitais gerais. Nesse novo quadro o hospital tradicional perdeu espaço. Foi preciso transformá-lo tanto física como conceitualmente, eliminando sua feição assistencial em benefício da terapêutica.

${ }^{2}$ Esta Lei dos Pobres, fortemente inspirada nas teorias higienistas do final do século XVIII, baseava-se no entendimento de que nos bolsões de pobreza londrinos estavam os focos das principais epidemias, o que justificava as medidas de intervenção sanitárias nessas localizações. A sujeira, a falta de drenagem dos pântanos e a ausência de esgotamento sanitário foram os principais problemas assinalados, e como solução adotou-se a instalação de encanamento que levava água potável para todas as cidades, bem como uma rede de esgoto, que desaguava para longe do perímetro urbano as águas servidas (Bourdelais, 2003).

${ }^{3}$ Esse hospital, posteriormente chamado de Hospital Paula Candido, destinava-se ao isolamento dos marítimos (imigrantes e marinheiros) acometidos de doenças contagiosas. Localizava-se em Jurujuba, Niterói, e foi extinto no século XX.

${ }^{4}$ Os cortiços eram considerados, desde o Império, como lugar da desordem e do contágio, e foram inúmeras as tentativas de destruílos ou impedir que fossem construídos. Contudo, a questão da propriedade privada - tão cara ao Império, pois poderia abrir um precedente no que tange à posse do escravo - impedia que as demolições ocorressem; quanto à fiscalização, sempre se encontrava uma forma de burlá-la (Chalhoub, 2004).
} 
${ }^{5}$ A Constituição de 1891 transferiu aos estados a gestão da saúde. No caso do Distrito Federal, coube à prefeitura a gestão e organização dos serviços. Assim foi criada, em 1893, a Diretoria-Geral de Higiene e Assistência Pública da cidade do Rio de Janeiro, com o objetivo de organizar, dirigir e distribuir, na cidade, os serviços de socorro médico gratuito - tanto em épocas 'normais' quanto epidêmicas - e o atendimento no caso de acidentes e desastres nos locais públicos, entre outros (Barbosa, 1908).

${ }^{6}$ Por exemplo, os franceses se sentiam atrasados nessa discussão em relação a seus vizinhos; a Inglaterra vinha discutindo a questão desde o início do século XIX, o que culminou com a reforma da Lei dos Pobres, e em Portugal o liberalismo passou a ser adotado desde o retorno de d. Pedro ao Reino. Data de 1834 a passagem do Hospital São José, o mais antigo de Lisboa, para o controle governamental, e de 1851 a ruptura definitiva do governo português com a Irmandade da Misericórdia.

${ }^{7}$ Eram estes os hospitais 'privados': os mantidos por irmandades e ordens terceiras; a Maternidade de Laranjeiras, de caráter semioficial; o Asilo São Luís; a Liga Brasileira contra a Tuberculose e as policlínicas Geral do Rio de Janeiro e de Botafogo.

${ }^{8}$ As 'rodas' eram o local onde se colocavam as crianças abandonadas, para que fossem levadas para o interior da instituição que as abrigava - no caso do Rio de Janeiro, a Casa dos Expostos (ou da Roda) da Santa Casa da Misericórdia, hoje Educandário Romão Duarte. Seu mecanismo de funcionamento permitia que a identidade da mãe ficasse preservada. Sua função era tentar salvar as crianças abandonadas - ou expostas - por meio do aleitamento por amas-de-leite e da educação, para que pudessem ser integradas à sociedade (Gandelman, 2001).

${ }^{9}$ Tais bases seriam: assistência à infância - menores abandonados e delinqüentes; puericultura; assistência à velhice; assistência à mulher; assistência aos estrangeiros; assistência pelo trabalho - a mendicidade profissional (questão penal); patronatos; assistência em domicílio e assistência hospitalar; assistência aos alienados; assistência aos tuberculosos; assistência aos leprosos, aos alcoólatras, aos sifilíticos; assistência metódica - meios práticos para obter uma aliança entre a assistência pública e a assistência privada; o problema no Brasil.

10 Jacques Tenon, arquiteto francês que lançou as bases do novo hospital francês, em 1788 (cf. cap. 5).

11 O DNSP foi criado em 1919 e regulamentado no ano seguinte. Era formado por uma Diretoria-Geral e três diretorias - a de Serviços Sanitários Terrestres na capital federal, a de Defesa Sanitária Marítima e Fluvial e a de Saneamento e de Profilaxia Rural -, além de dez inspetorias especiais, entre as quais as de Engenharia Sanitária; Profilaxia da Tuberculose; Estatística Demógrafo-Sanitária; Fiscalização do Exercício da Medicina, Farmácia, Arte Dentária e Obstetrícia; Profilaxia da Lepra e Moléstias Venéreas; Profilaxia Marítima (Hochman, 1998).

12 Foram financiados pela família Guinle os hospitais Gaffrée \& Guinle e do Câncer, atual Hospital Municipal Barata Ribeiro.

${ }^{13}$ Vale ressaltar que as bases do Projeto Mascarenhas haviam sido defendidas, em 1923, no editorial da revista Brazil-Médico.

\section{Referências}

ABREU, L. (Ed.) Igreja, Caridade e Assistência na Península Ibérica (sécs. XVI-XVIII). Évora: Edições Colibri, Cidehus/Universidade de Évora, 2004.

ACTAS e Trabalhos do Primeiro Congresso Nacional dos Práticos: em comemoração do centenário do Brasil. Rio de Janeiro: Publicações Scientíficas, 1923.

ALLAIN, E. Rio de Janeiro: quelques données sur la capitale et sur l'administration du Brésil. Paris, Rio de Janeiro: L. Firenze et Cie Éditeurs, Lachaud et Cie, 1886.

ALMEIDA, G. Assistência Hospitalar: memória apresentada ao Congresso Nacional de Assistência Pública e Privada do Rio de Janeiro. Rio de Janeiro: Typographia Jornal do Commercio, 1908.

ASSISTÊNCIA Pública e Privada no Rio de Janeiro (Brasil): história e estatística. Rio de Janeiro: Prefeitura do Distrito Federal, 1922.

BARBOSA, L. Serviços de Assistência no Rio de Janeiro. Rio de Janeiro: Typographia Ao Luzeiro, 1908.

BENCHIMOL, J. Pereira Passos: um Haussmann tropical. Rio de Janeiro: Secretaria Municipal de Cultura, Turismo e Esportes/Departamento Geral de Documentação e Informação Cultural, 1992. (Biblioteca Carioca)

BENCHIMOL, J. (Coord.) Febre Amarela: a doença e a vacina, uma história inacabada. Rio de Janeiro: BioManguinhos, Editora Fiocruz, 2001.

BOURDELAIS, P. Les logiques du développement de l’hygiène publique. In: BOURDELAIS, P. (Dir.) Les Higiénistes, Enjeux, Modèles et Pratiques (XVIII $-X X^{e}$ siècles). Paris: Belin, 2001. 
BOURDELAIS, P. Les Épidemies Terrassées: une histoire des pays riches. Paris: Éditions de la Martinière, 2003.

BOURDELAIS, P. Les bureaux d'hygiène municipaux (1879-1900): connaître, décider, innover, assister, convaincre e diffuser. In: BOURDELAIS, P. \& FAURE, O. Les Nouvelles Pratiques de Santé, XVIII ${ }^{e}-X X^{e}$ Siècles. Paris: Belin, 2005.

BRASIL. Anais da Câmara dos Deputados. Rio de Janeiro: Imprensa Nacional, 1920.

BRASIL. Anais da Câmara dos Deputados. Rio de Janeiro: Imprensa Nacional, 1921.

BRASIL. Anais da Câmara dos Deputados. Rio de Janeiro: Imprensa Nacional, 1923.

BRASIL. Mensagens ao Congresso: Washington Luis P. de Sousa. Rio de Janeiro: Imprensa Nacional, 1930.

BRASIL. Mensagens ao Congresso: obras completas de Epitácio Pessoa. Rio de Janeiro: INL, 1956. v. XVII.

CHAGAS, C. Discurso do Dr. Carlos Chagas no banquete offerecido pela classe medica do Rio de Janeiro, no Edifício do Derby-Club, em homenagem aos medicos bahianos, em 9 de dezembro de 1918. Rio de Janeiro: Typ. Jornal do Commercio, de Rodrigues, 1919. Biblioteca Virtual Carlos Chagas <www4.prossiga.br/chagas/>. Acesso em: 2 maio 2003.

CHALHOUB, S. Cidade Febril: cortiços e epidemias na corte imperial. 3. ed. São Paulo: Companhia das Letras, 2004. CORBAIN, A. Le Miasme et la Jonquille. Paris: Flammarion, 1986.

DUPRAT, C. Pour l'Amour de l'Humanité - Le Temps des Philantropes: la philantropie parisienne des Lumières à la monarchie de Julliet. Paris: Éditions CTHS, 1993. t. 1.

DUPRAT, C. Usage et Pratiques de la Philantropie: pauvreté, action sociale et lien social, à Paris, au cours du premier XIX ${ }^{e}$ sciècle. Paris: Comité d'Histoire de la Sécurité Sociale, 1996. v. 1 et 2.

FAURE, O. Les Français et leur Médecine aux XIX' Siècle. Paris: Belin, 1993.

FIGUEIRA, A. Reforma dos hospitais. Brazil-Médico, 15 ago. 1902, p. 311-312.

FIGUEIRA, A. Assistência pública: assistência à infância e particularmente o que se refere às medidas a adotar contra a mortalidade infantil. Educação das crianças deficientes. Relatório apresentado ao Congresso Nacional de Assistência Pública e Privada. Brazil-Médico, 1 e 8 nov. 1908, p. 401-405, 411-415, 419-420.

GANDELMAN, L. M. A Santa Casa da Misericórdia do Rio de Janeiro nos séculos XVI a XIX. História, Ciência, Saúde - Manguinhos, 8(3): 613-630, dez. 2001.

GOMES, A. Burguesia e Trabalho. Rio de Janeiro: Editora Campus, 1979.

HOCHMAN, G. A Era do Saneamento. São Paulo: Hucitec, Anpocs, 1998.

HORNE, J. Le Musée Social: aux origines de l'État providence. Paris: Belin, 2004.

LIVRO de ofícios da Faculdade de Medicina do Rio de Janeiro para o ano de 1923. (Mimeo.)

MENDONÇA, J. Assistência hospitalar no Rio de Janeiro. Correio da Manhã, 14 jun. 1920, p. 2.

MENDONÇA, J. A organização econômica do hospital moderno. Revista do Brasil, XXVI(101): 8-15, maio 1924.

MONCORVO FILHO. Assistência pública no Rio de Janeiro e particularmente da assistência à infância. Comunicação enviada ao IV Congresso Internacional de Assistência Pública e Privada, realizado em Milão em 1906. Rio de Janeiro: Imprensa Nacional, 1907.

NOTÁVEL empreendimento - Hospital de Clínicas 'Arthur Bernardes', o lançamento de sua pedra fundamental (1926). Vida Doméstica - Revista da Família e da Mulher, 101, jul. 1926.

OLIVEIRA, J. \& TEIXEIRA, S. (Im)Previdência Social: 60 anos de história da previdência social no Brasil. Petrópolis, Rio de Janeiro: Vozes, Abrasco, 1986.

PAIVA, A. Justiça e Assistência. Rio de Janeiro: Typographia do Jornal do Commercio, 1916.

POLANYI, K. A Grande Transformação: as origens da nossa época. São Paulo: Campus, 2000.

SANGLARD, G. Da Misericórdia ao Estado: questões de saúde no Brasil na primeira metade do século XX. In: PRIEGO, N. \& LOZANO, S. (Orgs.) Paradigmas, Culturas y Saberes: la transmisión del conocimiento científico a Latinoamérica. Madrid: Editorial Iberoamericana, 2007.

SANGLARD, G. Entre os Salões e o Laboratório: Guilherme Guinle, a saúde e a ciência no Rio de Janeiro. Rio de Janeiro: Editora Fiocruz, 2008. (Col. História \& Saúde) 


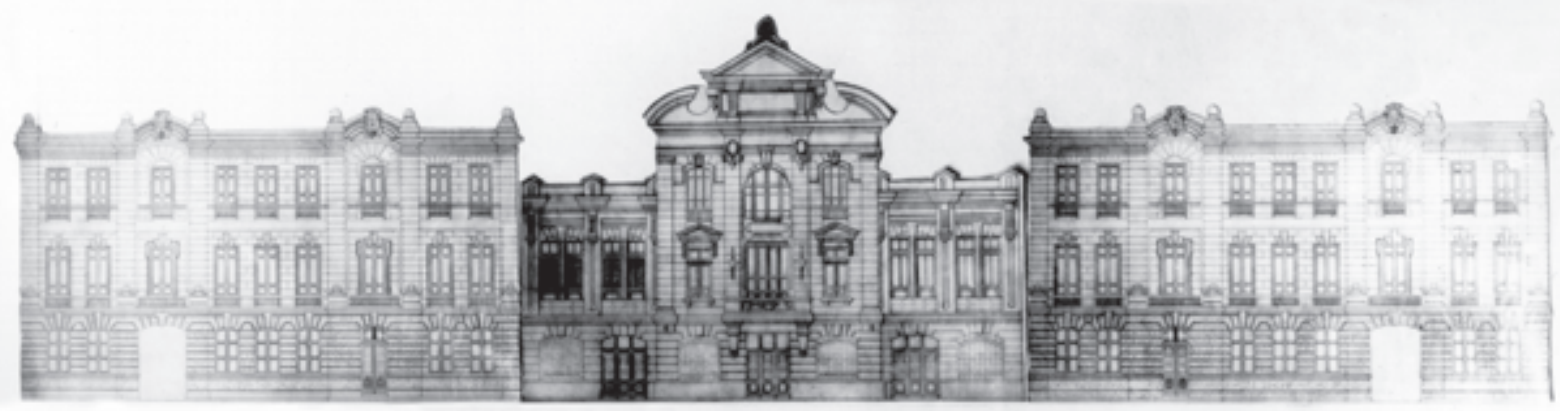

Posto Central de Assistência, [s.d.]. Acervo Arquivo Geral da Cidade do Rio de Janeiro

O pronto-socorro municipal foi inaugurado em 1907, na rua Camerino. Em 1910 o atual Hospital Municipal Souza Aguiar foi transferido para a praça da República, onde permanece até hoje em conjunto arquitetônico dos anos 1970.

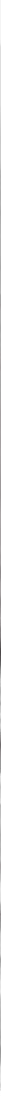

Vista aérea do Instituto Oswaldo Cruz, [1920]. Acervo Casa de Oswaldo Cruz

Nesta foto percebe-se o Núcleo Arquitetônico Histórico da Fundação Oswaldo Cruz, formado pelo Pavilhão Mourisco, o Quinino, a Cavalariça, o Pavilhão do Relógio (ou Pavilhão da Peste) e o Aquário, este já destruído. A arquitetura neomourisca singulariza o castelo não apenas em relação às demais construções do conjunto, mas como um dos mais destacados edifícios civis construídos para a saúde no início do século XX no Rio de Janeiro. 


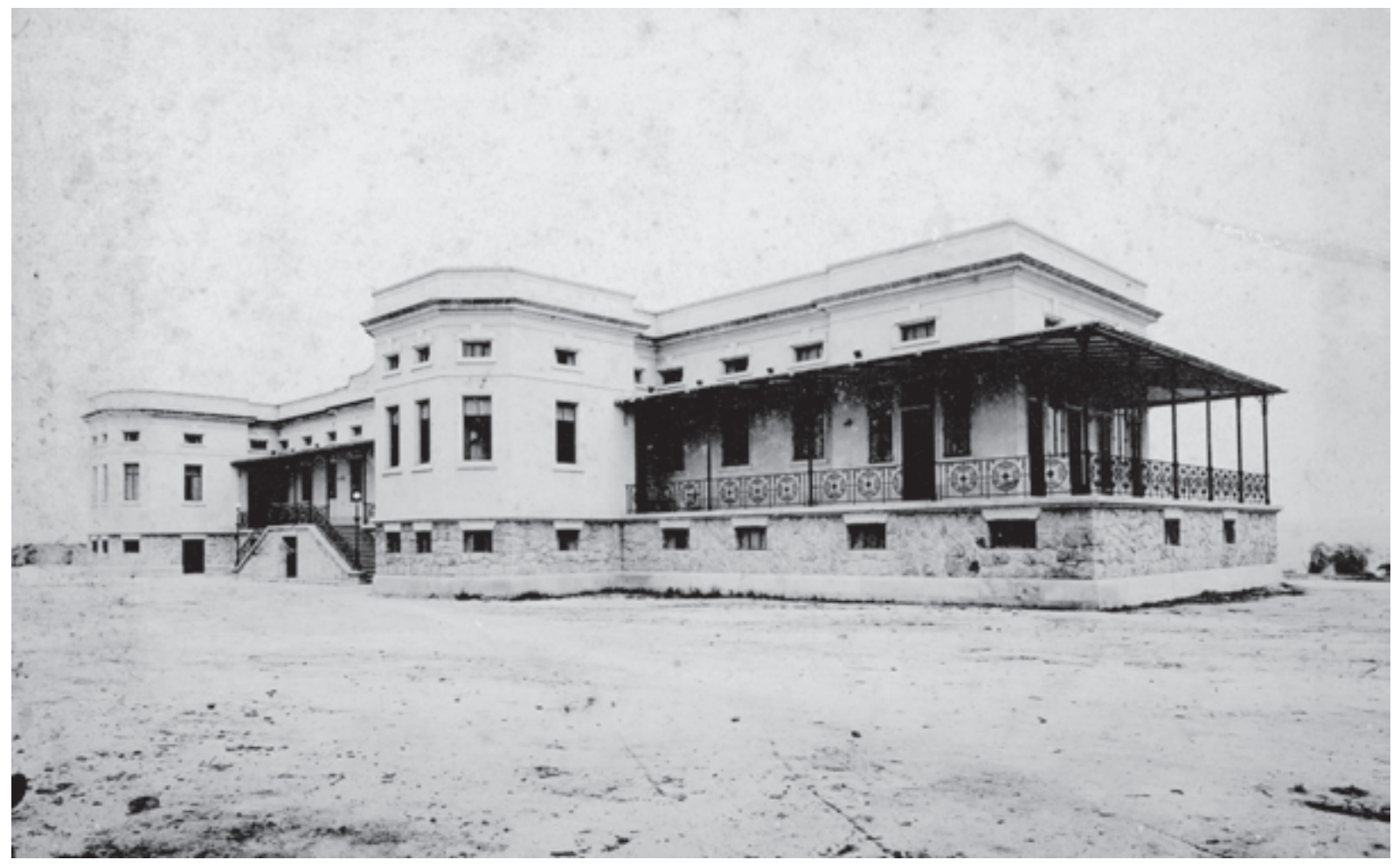

Hospital Oswaldo Cruz, [s.d.]. Acervo Casa de Oswaldo Cruz

Este é o único dos seis pavilhões projetados por Luiz Moraes Jr., entre 1912 e 1917, para o Hospital Oswaldo Cruz, hoje Hospital Evandro Chagas. Sua inauguração em 1918 enfatiza a importância do estudo das grandes endemias para a instituição.

\begin{abstract}
Hospital do Amparo Feminino, [s.d.]. Acervo particular

O Hospital do Amparo Feminino, inaugurado em 1924, era mantido pela Associação das Senhoras

Evangélicas para dar assistência materno-infantil às mulheres carentes da colônia alemã e contava com maternidade e berçário. Nos anos 1960 a instituição ganhou um outro edifício com características arquitetônicas próximas às do art déco.
\end{abstract}

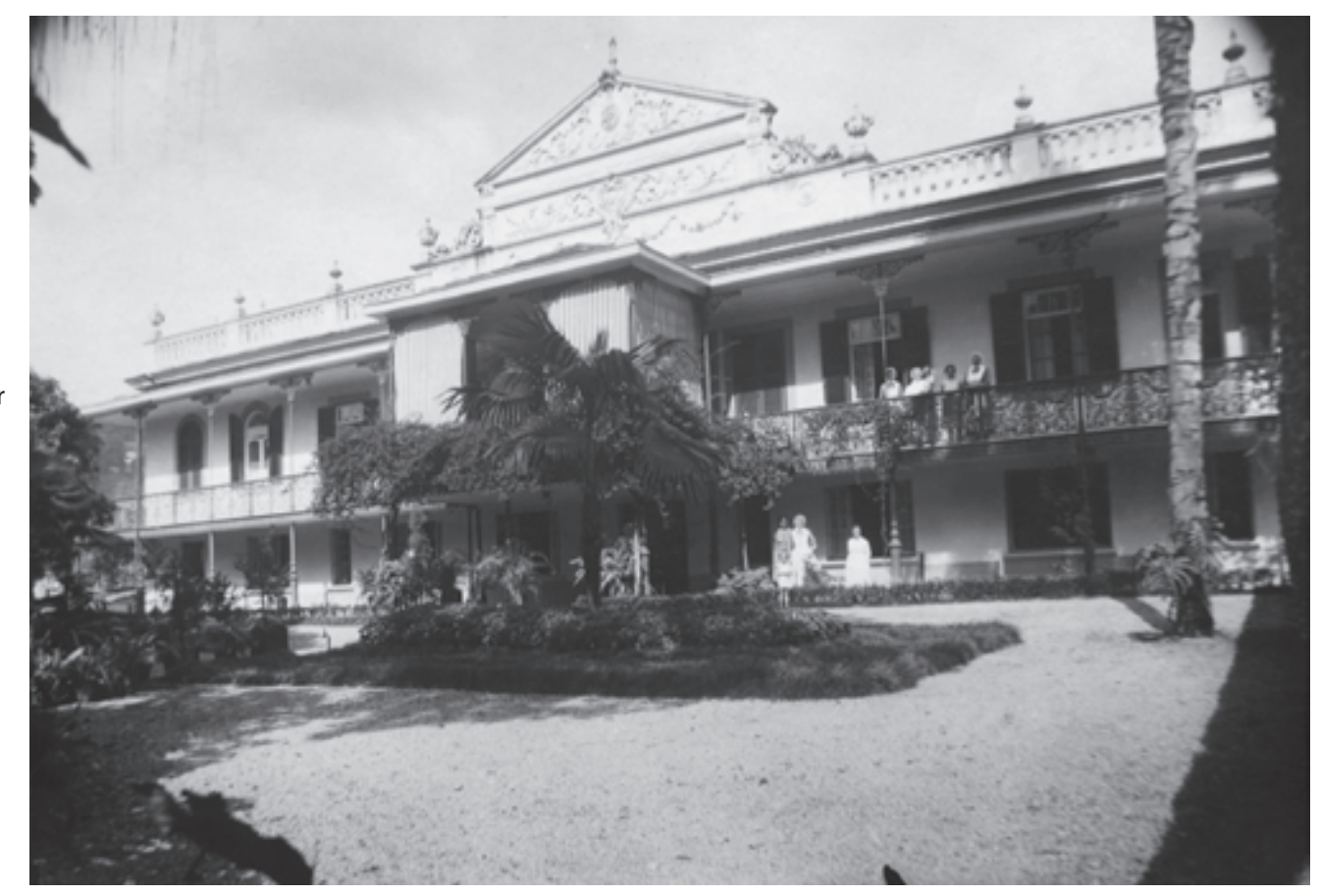


A Primeira República e a Constituição de uma Rede Hospitalar...

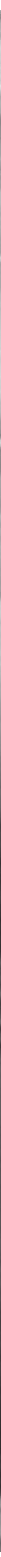

Perspectiva do projeto do Hospital e Instituto do Câncer na Mangueira, [1927]. Acervo Casa de Oswaldo Cruz, Coleção Porto d'Ave

As obras deste conjunto foram, destinadas à construção de um Hospital e Instituto do Câncer, financiados pela família Guinle, iniciaram-se em 1927 e foram abandonadas em 1936, quando as instalações foram doadas à prefeitura, que lá estabeleceu o Hospital Barata Ribeiro. 


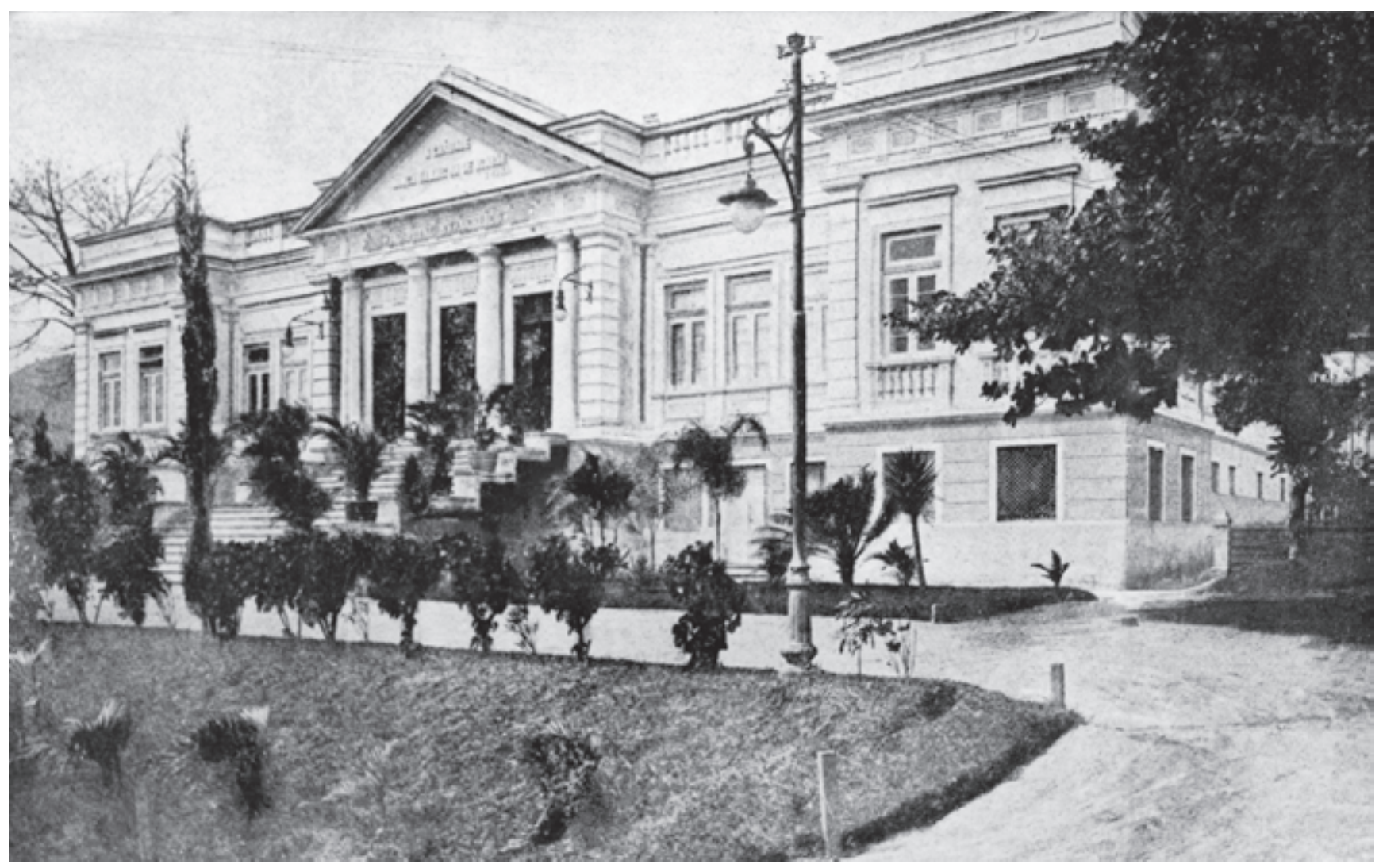

Fachada principal do Hospital Evangélico, [s.d.]. Acervo Hospital Evangélico

O Hospital Evangélico foi criado para dar atendimento médico à colônia alemã no Rio de Janeiro no final do século XIX e inaugurado em 1912. O prédio mantém-se inalterado, e nos anos 1970 o hospital ganhou um edifício de três andares. Encontra-se atualmente em fase de expansão.

Perspectiva geral do Hospital

Gaffrée \& Guinle, [1924-1929]. Acervo Casa de Oswaldo Cruz, Coleção Porto d'Ave

Hospital construído pela família Guinle para o tratamento e profilaxia da sífilis e de outras doenças venéreas. Na década de 1966 um acordo entre a Fundação Gaffrée e Guinle e o governo federal passou a responsabilidade pelo hospital para a alçada federal e o transferiu para a Faculdade de Medicina e Cirurgia do Rio de Janeiro, hoje Universidade Federal do Estado do Rio de Janeiro (UniRio).

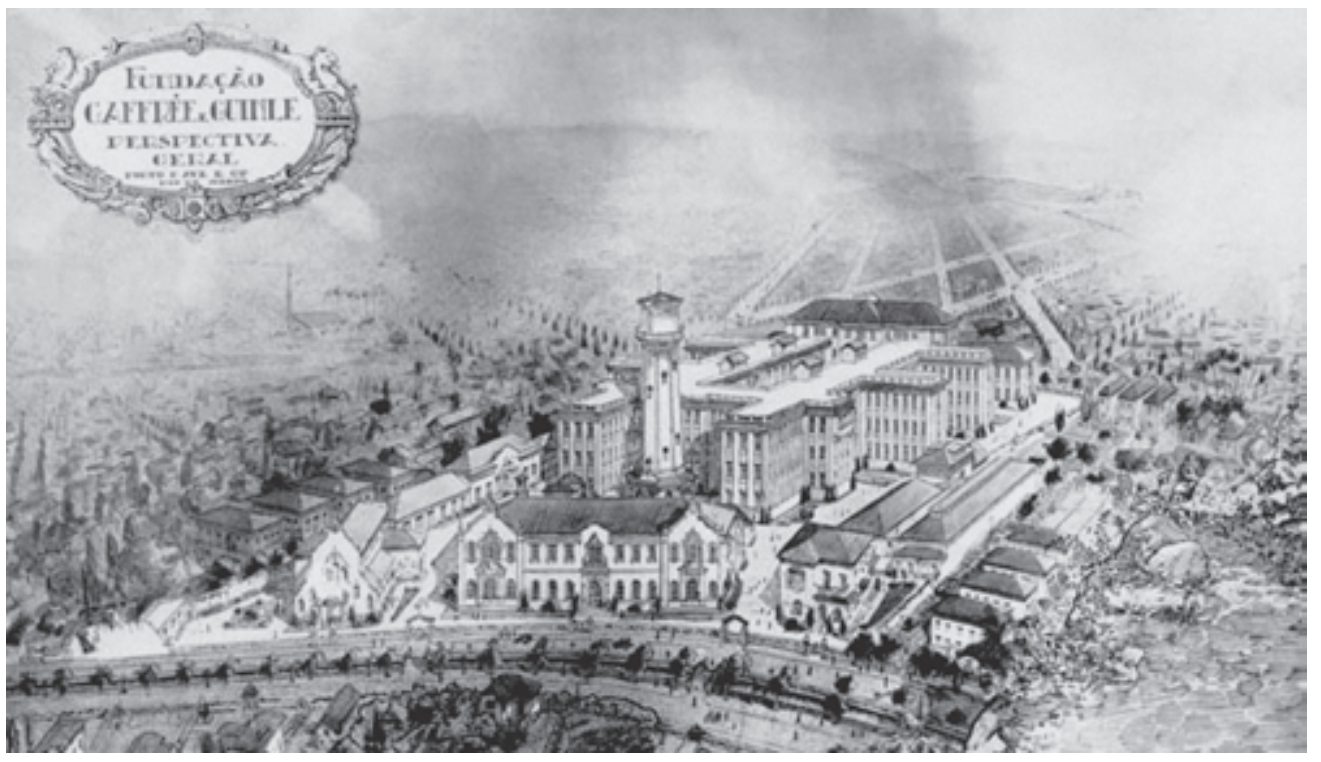


A Primeira República e a Constituição de uma Rede Hospitalar...

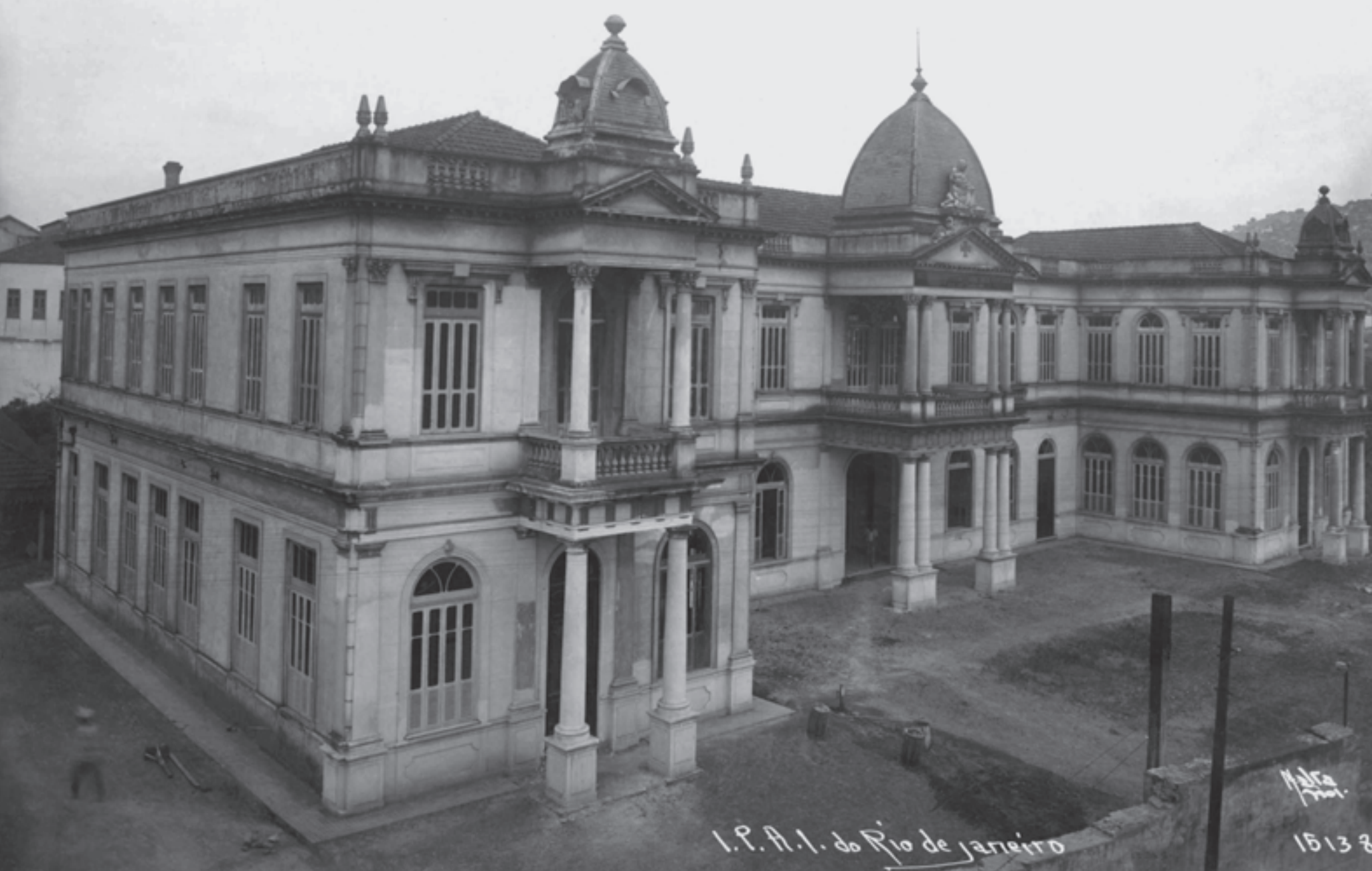

Instituto de Proteção e Assistência à Infância (Ipai) ainda em construção, [s.d.]. Foto Augusto Malta. Acervo Museu da Imagem e do Som, RJ

O Instituto de Proteção e Assistência à Infância foi criado em 1889 pelo médico Arthur Moncorvo Filho e transferiu-se para este prédio em 1914. Atualmente abriga o Instituto de Ginecologia da Faculdade de Medicina da UFRJ e, em prédio anexo construído na década de 1960, o Instituto Estadual de Diabetes e Endocrinologia Luiz Capriglione (lede). 


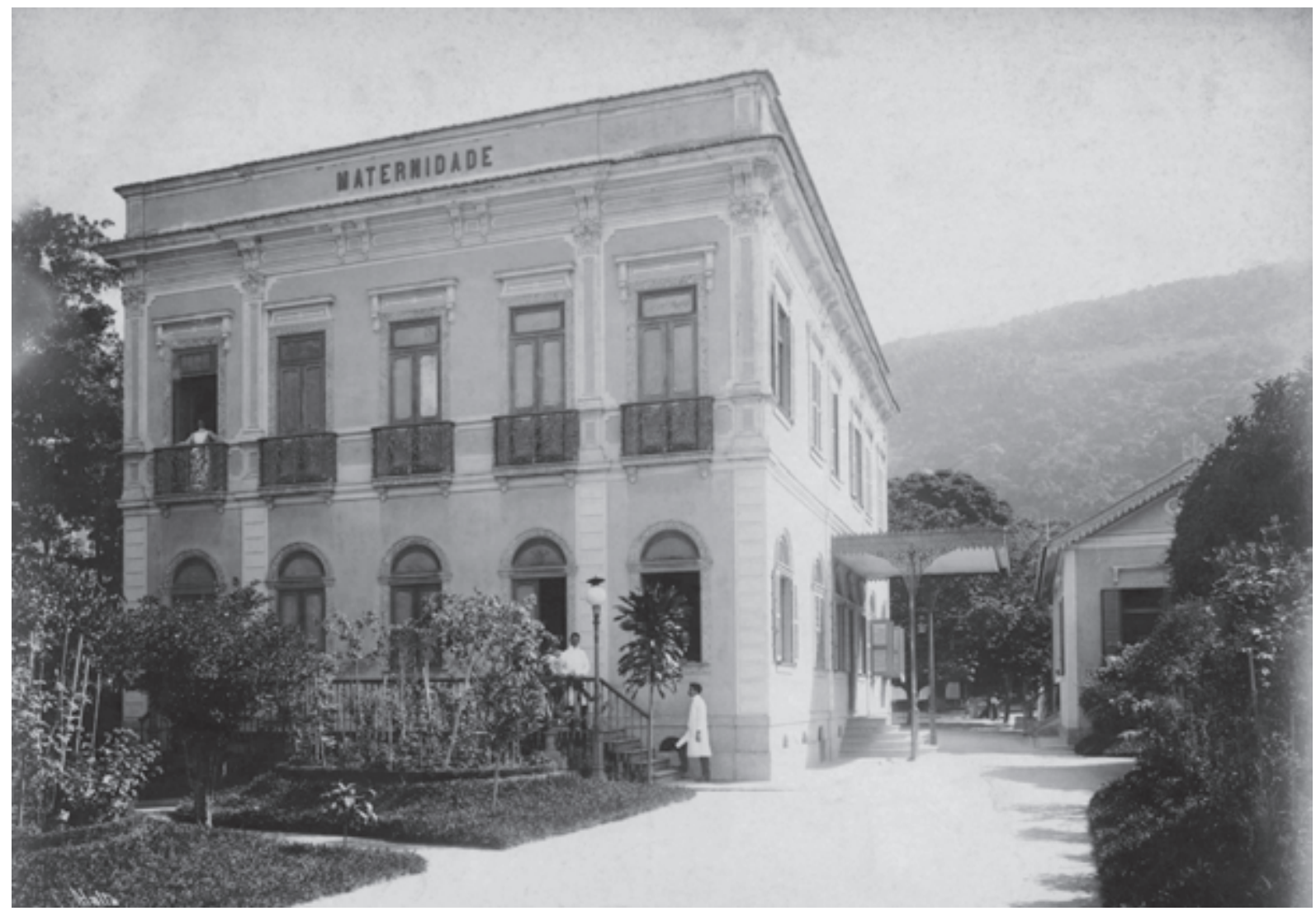

Maternidade de Laranjeiras, [s.d.]. Acervo Museu da Imagem e do Som, RJ

A Maternidade-Escola da UFRJ, criada em 1904, foi instalada em um palacete da rua das Laranjeiras que a abriga até hoje, apesar de completamente descaracterizado. Criada como instituição filantrópica, foi incorporada à Faculdade de Medicina em 1918, que lá instalou a cátedra de obstetrícia.

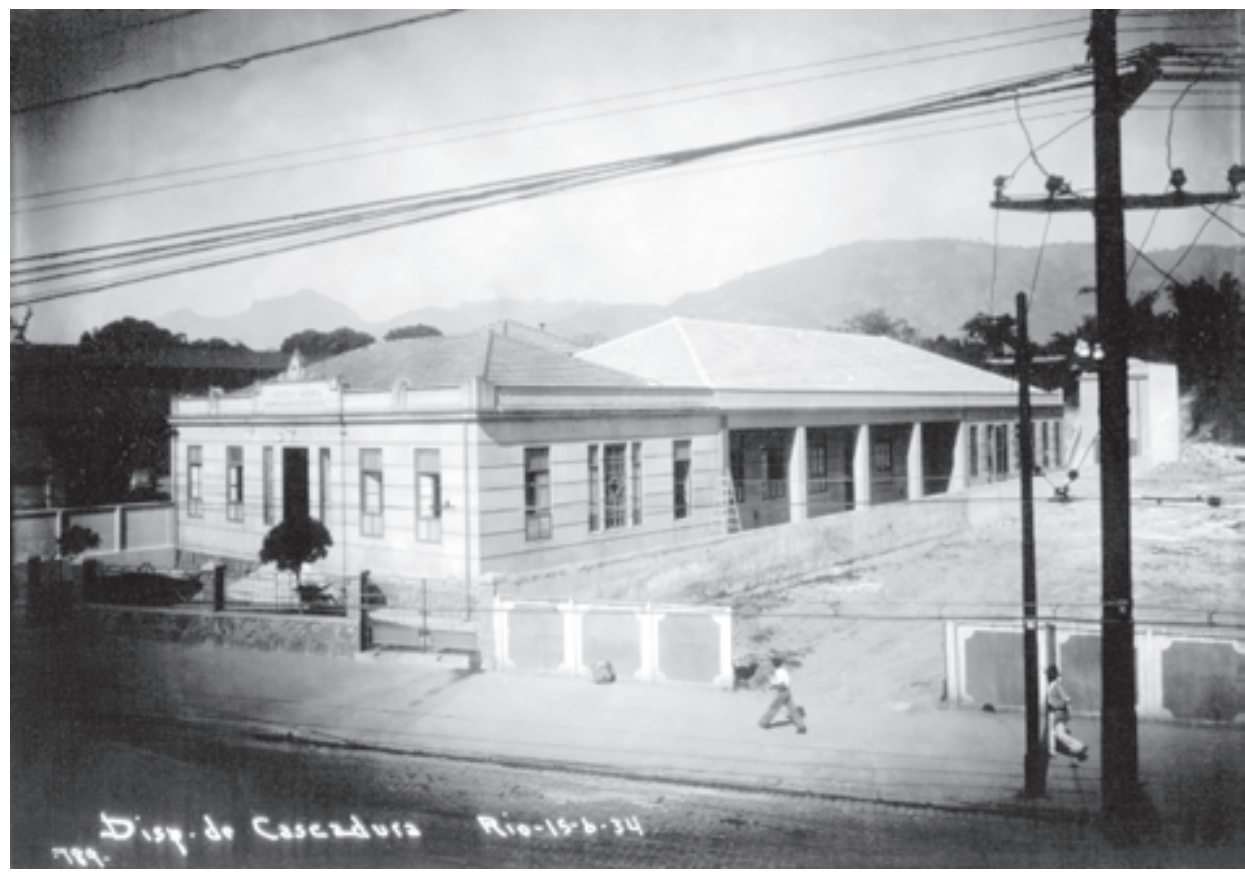

Dispensário de Cascadura, 1934. Foto Augusto Malta. Acervo Arquivo Geral da Cidade do Rio de Janeiro

O Dispensário de Cascadura remonta à criação, em 1926, de uma maternidade filantrópica (Maternidade de Cascadura ou Suburbana) doada, em 1933, à prefeitura, que lá instalou o dispensário e ampliou suas instalações. Mantém sua vocação para o cuidado da gestante, com o nome de Hospital-Maternidade Herculano Pinheiro. 


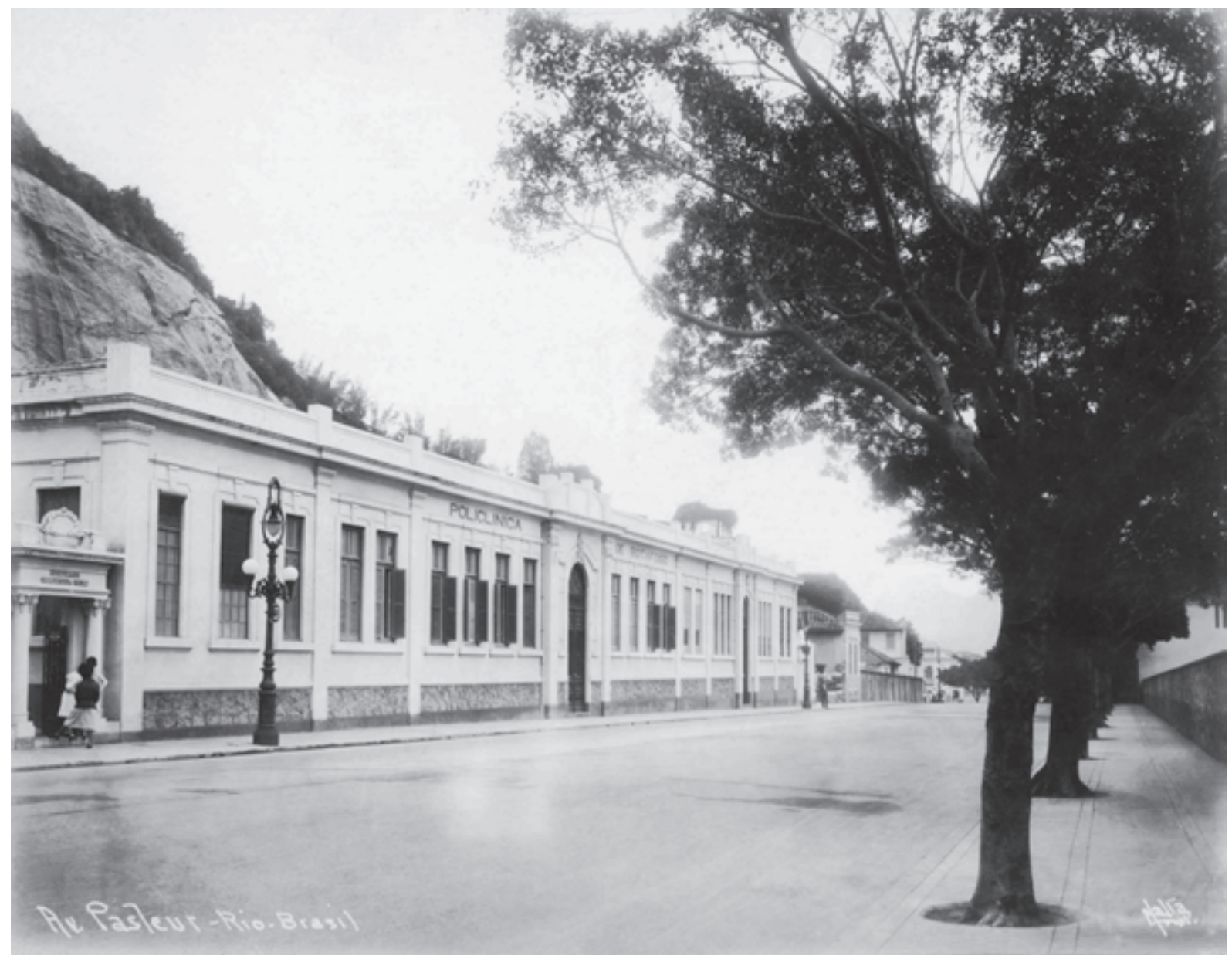

Fachada da Policlínica de Botafogo, [1922]. Foto Augusto Malta. Acervo Museu da Imagem e do Som, RJ

O prédio da Policlínica de Botafogo foi inaugurado em 1922 e é a segunda sede da instituição. A policlínica foi criada pelo médico Luiz Barbosa em fins de 1899 e iniciou seus atendimentos em junho de 1900. Sua marca mais forte era a atuação paroquial, restrita aos moradores de Botafogo e adjacências.

Sede da Diretoria-Geral de Saúde Pública, [s.d.]. Fonte: Arquivos de Higiene Este prédio foi construído na década de 1910 para abrigar a Diretoria-Geral da Saúde Pública, órgão vinculado ao Ministério da Justiça e Negócios Exteriores, responsável pelas ações de saúde pública no Distrito Federal. Atualmente integra o patrimônio do Instituto Nacional de Câncer (INCa).

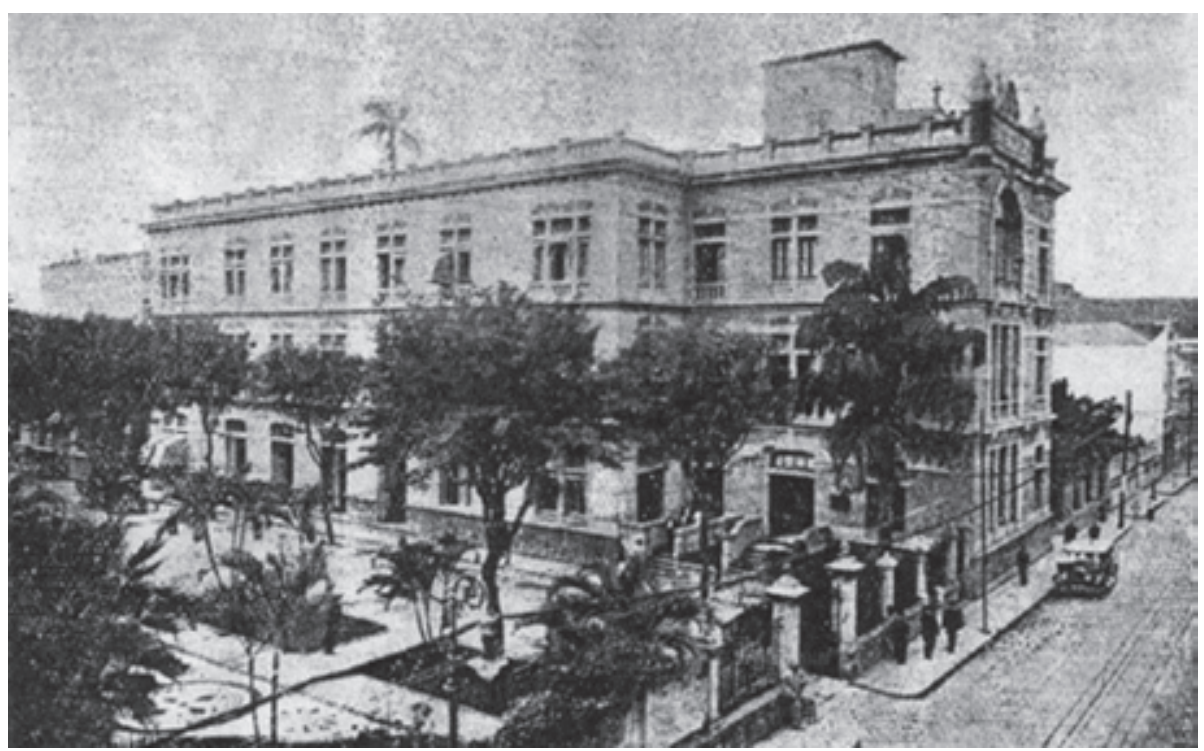




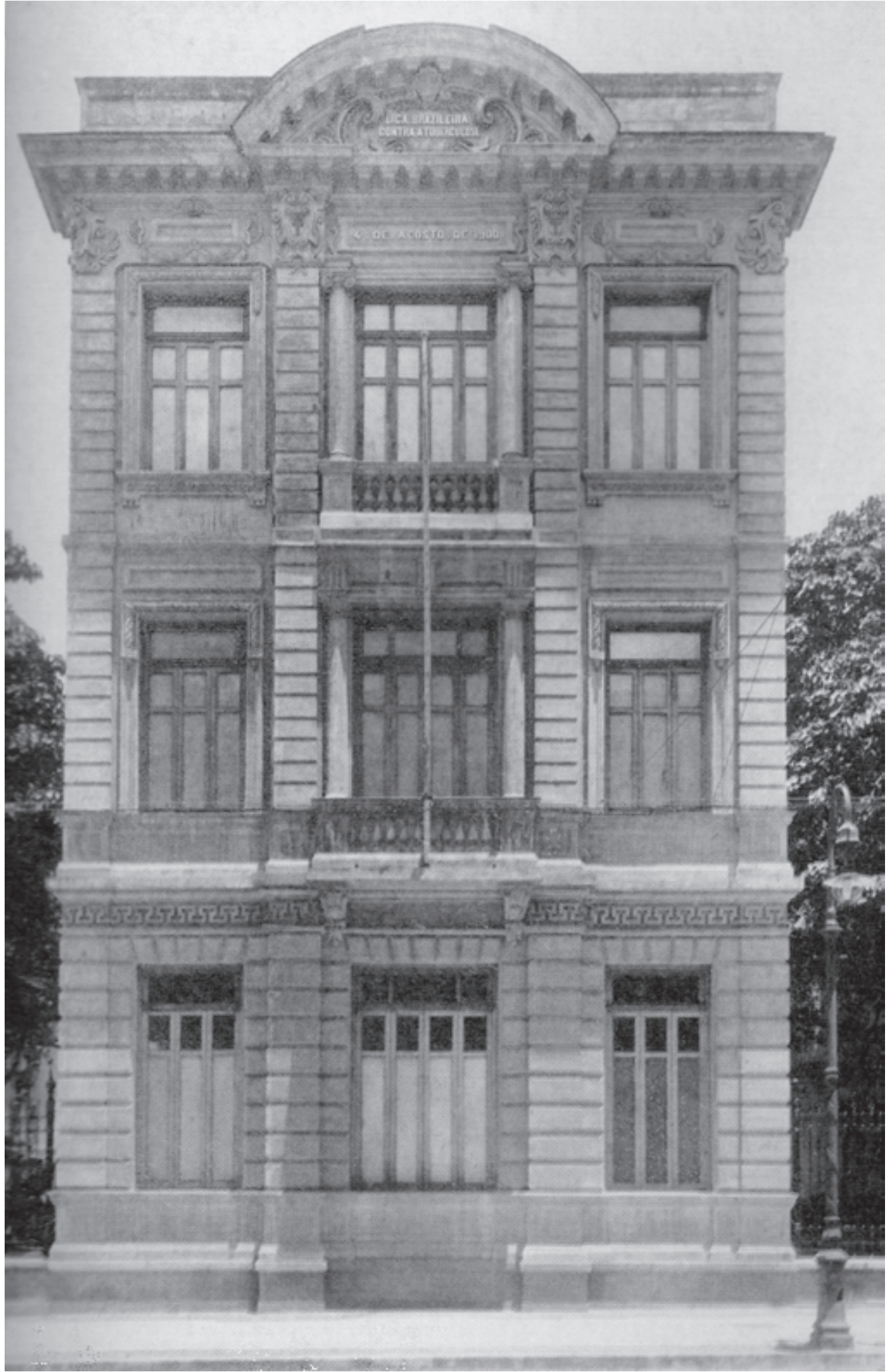

Dispensário

Azevedo Lima e sede da Liga,

1901. Acervo

Fundação Ataulfo de Paiva

Prédio

emblemático da

campanha contra a

tuberculose no Rio

de Janeiro,

construído pela

Liga Brasileira

contra a

Tuberculose em

1901. Apesar de

ter sido destruído

para abrigar um

arranha-céu da

Fundação Ataulfo de Paiva, o edifício

é simbólico do trabalho desta instituição. 
A Primeira República e a Constituição de uma Rede Hospitalar...

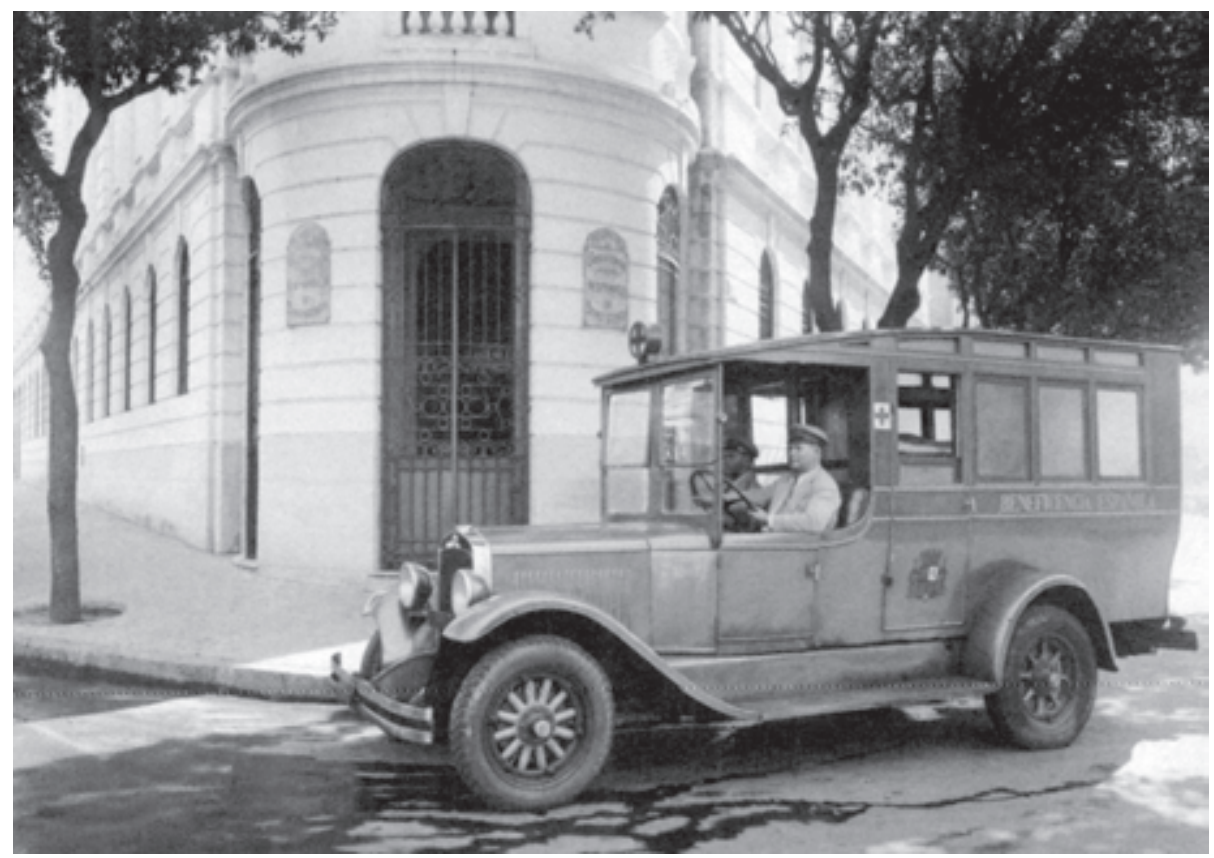

Fachada da antiga entrada principal do Hospital

Espanhol, com ambulância da Sociedade de

Beneficência à frente, [1930]. Acervo Sociedade Espanhola de Beneficência

Em 1927 a Sociedade de Beneficência Espanhola consegue, enfim, oferecer atendimento médicohospitalar para a colônia espanhola, após adquirir o prédio da antiga Casa de Saúde do Dr. Crissiúma, onde foi instalado o hospital. Desde então o prédio sofreu diversas modificações.

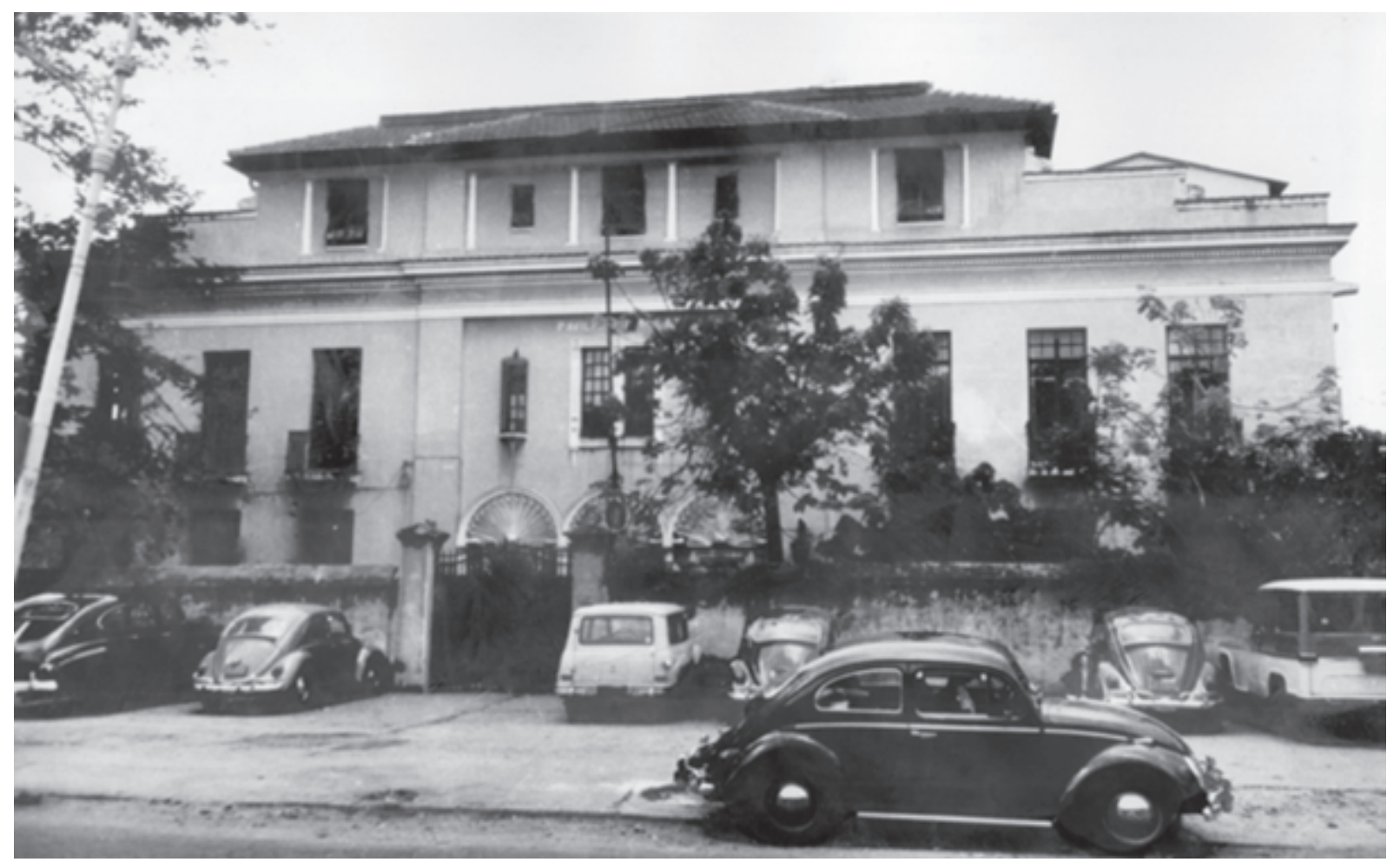

Escola de Enfermagem Anna Nery, [s.d.]. Acervo Universidade Federal do Rio de Janeiro

A Escola de Enfermagem Anna Nery foi criada em 1922 para formar um quadro de enfermeiras de saúde pública. Em 1926 iniciouse a construção de seu edifício-sede, em terreno pertencente ao Hospital São Francisco de Assis, onde eram realizadas as aulas práticas da escola. 


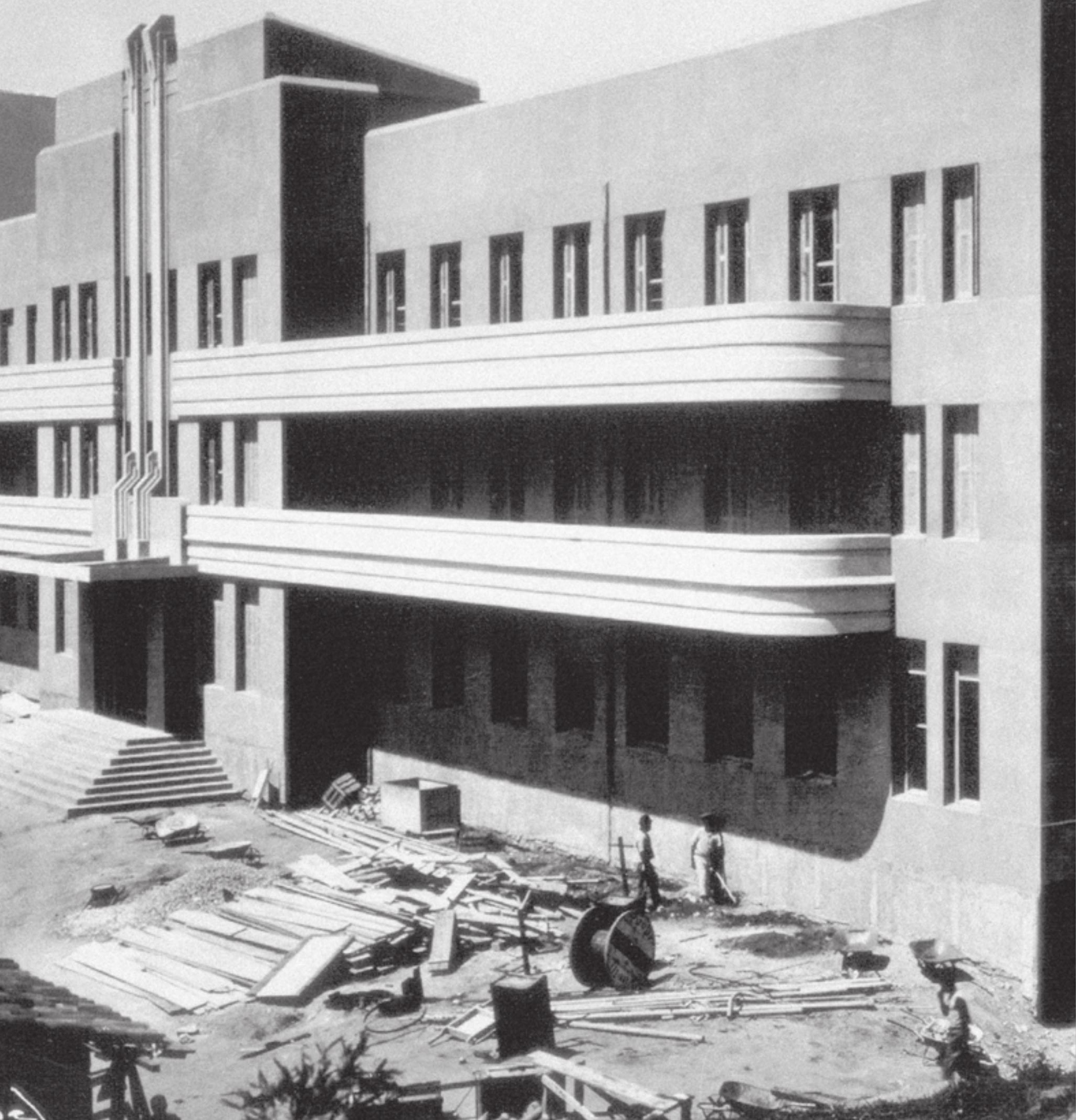


4

\section{Politica e Saúde: diretrizes nacionais e assistência médica no Distrito Federal no pós-1930}

Cristina M. Oliveira Fonseca 
A saúde, nas primeiras décadas do século XX, já se constitui como um bem público, carrega em si uma dimensão política que lhe é intrínseca. Portanto, para compreender as características apresentadas pela assistência médica a partir dos anos 1930, é preciso que se tenha claro que a adoção de um determinado modelo institucional de prestação de serviços de saúde é em si uma opção política, traduz a escolha de um caminho, de prioridades e a definição de estratégias para alcançá-las. Além disso, o desenho institucional adotado pelo governo em um contexto político específico expressa também uma forma de relação na esfera pública entre as entidades governamentais e a população, que usufruirá desse bem coletivo, expressando uma outra dimensão desse papel político da saúde.

No caso da assistência médica a partir dos anos 30 do último século, dois aspectos são essenciais para a compreensão das características que esse desenho institucional assumiu e suas interações com a esfera política: a relação entre o governo federal e os estados e municípios; e a relação entre saúde pública e assistência médica, a forma como essas duas dimensões da prestação de serviços foram definidas. Analisar essas relações é fundamental para situar uma questão que atravessou o século XX e continua presente ainda hoje, nos debates relativos à política pública de saúde no Brasil: quais as atribuições específicas de cada esfera do Executivo - municipal, estadual e federal - na definição de competências e responsabilidades na prestação de serviços de saúde à população brasileira?

As transformações por que passou a organização institucional da assistência médica do Distrito Federal, a partir dos anos 1930, só podem ser compreendidas em diálogo com as transformações que ocorreram na política de saúde em âmbito federal. Tal diálogo se processa em sua dimensão política, presente na relação dos líderes locais - como Pedro Ernesto - com o governo Vargas e nas atribuições definidas para a capital da República. E se expressa também em sua dimensão organizacional, quando uma série de normas e regras começaram a ser adotadas e impuseram diretrizes ao funcionamento do serviço público de saúde em todo o país, com repercussões sobre o Distrito Federal, até então alvo prioritário das ações e investimentos federais em saúde.

Tendo tais referências como ponto de partida, procuro analisar aqui determinados aspectos da política de assistência médica implementada no primeiro governo de Getulio Vargas. Inicialmente traço um rápido panorama do quadro político da época, destacando a instabilidade do pós-30, os interesses em jogo nesse momento de transição e algumas das diretrizes ideológicas que nortearam o debate político e orientaram a política de saúde. Sem compreender o contexto político nacional, não será possível entender 
as transformações em curso na capital da República. Em seguida, destaco as principais características das mudanças institucionais implementadas na área da saúde, conduzidas pela necessidade de assegurar a expansão do poder público em todo o país, levando à adoção, por parte do Departamento Nacional de Saúde (DNS), de um modelo de gestão caracterizado por uma centralização administrativa e descentralização executiva. Procuro apresentar os princípios básicos que orientaram a organização e gestão da assistência médica em todo o país e de que forma os serviços de saúde do Distrito Federal se inscrevem neste debate.

$\mathrm{Na}$ terceira parte detenho-me nas principais características da estrutura de assistência médica do Distrito Federal, chamando a atenção para as especificidades que sua condição de capital da República lhe imprimia. Os serviços do Distrito Federal ganharam uma dimensão própria, pois não eram federais mas também não se encontravam na mesma condição dos serviços estaduais: eram geridos por normas específicas, que sua condição de sede do governo federal lhe assegurava. Trata-se, portanto, de um novo momento de redefinição das atribuições da União, quando a necessidade do governo federal de expandir sua atuação para o restante do país e fortalecer politicamente sua presença nos estados implicou também mudanças para a política pública de saúde da cidade do Rio de Janeiro.

\section{Características do Contexto Político Nacional}

No imediato pós-1930, o período compreendido pelo Governo Provisório (1930-1934) foi marcado por grande instabilidade política, devida, entre outros fatores, à heterogeneidade de forças que haviam se aliado durante o processo revolucionário. Nessa conjuntura política tornou-se evidente que o setor agroexportador brasileiro passava por uma crise de hegemonia, identificada principalmente nas dissidências regionais. Como os demais setores da sociedade - no caso, os grupos agrários não ligados ao café e os grupos urbanos emergentes - não se encontravam suficientemente coesos para se constituírem como uma força política hegemônica, os desdobramentos do movimento de outubro foram condicionados pelas disputas políticas entre as diferentes facções que haviam se reunido em torno da Aliança Liberal, particularmente entre tenentes e oligarquias dissidentes (Gomes, 1980). A própria estrutura oligárquica herdada da República Velha trazia consigo importantes diferenciações que haviam marcado disputas políticas e agora se faziam presentes de forma mais intensa. Considerando o que Werneck Vianna (1976) caracterizou, com base em Lima Sobrinho (1975), como liberalismo excludente da Primeira República, torna-se possível afirmar que a oligarquia agrária contou com setores que se opunham à ala agroexportadora e resistiam aos rumos que tomara o movimento de 1930. A relação desigual entre os estados marcou a Primeira República, traduzindo uma concepção de federalismo orientada pelas noções de privilégio e exclusão. A discriminação poderia ser observada na política de sucessão presidencial, quando os estados eram distribuídos em três classes, segundo o grau de sua importância para a tomada de decisões.

A bem falar, os Estados de primeira classe, acreditados para a reivindicação da Presidência da República, eram apenas dois: São Paulo e Minas Gerais. Os de segunda classe, que podiam candidatar-se à Vicepresidência, eram a Bahia, Pernambuco e Rio de Janeiro. Os outros formavam a terceira classe, os bagageiros da Federação, que só por acaso recebiam a oportunidade de indicarem um tertius, que nunca 
vinha pela força do Estado, mas pelas amizades e prestígio político dos homens que merecessem tão grande distinção. (Lima Sobrinho apud Vianna, 1976: 102) ${ }^{1}$

Foi o rompimento do acordo entre os dois estados principais um dos fatores que contribuíram para a deflagração do movimento revolucionário de 1930, colocando Minas Gerais e Rio Grande do Sul como aliados contra São Paulo (Schwartzman, 1982). No plano político, as diferenças regionais se faziam acompanhar pelos interesses econômicos, que se diversificavam na mesma medida, como mostrou Diniz (1981). Para a autora, a década de 1930 caracterizou-se por mudanças significativas no plano econômico, com destaque para o surto industrial de vulto ocorrido entre 1929 e 1939, com tendência à substituição da atividade agrícola em determinadas regiões do país. As mudanças na esfera econômica seriam traduzidas, assim, no deslocamento da produção de exportação para aquela voltada para o mercado interno, incluindo a atividade industrial. Com a diversificação da economia, novos interesses surgiram e pressionaram a antiga ordem e sua estrutura de poder. As oposições concentravam-se na forma de organização política em vigor, que inviabilizava a participação das forças sociais emergentes. Em outras palavras, a perda da hegemonia do setor cafeeiro contribuiu para acirrar as cisões regionais. Entretanto, nenhum dos grupos em confronto logrou impor-se aos demais, o que levou a uma reformulação no esquema de alianças entre os grupos dominantes. Isso talvez explique por que não houve uniformidade na política econômica implementada, e medidas favoráveis à industrialização coexistiram com outras que visavam a amparar os interesses agrários tradicionais (Boris Fausto apud Diniz, 1981).

Os tenentes, apoiados em uma crítica acentuada ao liberalismo - aqui associado à prática política implementada durante a República Velha -, defendiam um modelo de Estado nitidamente centralizador e intervencionista. Tais princípios já haviam sido indicados no programa do Clube 3 de Outubro, que defendia "um Executivo forte, conselhos técnicos e uma máquina administrativa voltada para os interesses nacionais" (Camargo et al., 1989: 23). Já os setores oligárquicos dissidentes lutavam pelo federalismo como modelo de Estado ideal, pois nele poderiam manter a autonomia estadual e restringir a interferência da União. O debate entre centralização e federalismo representou a síntese das divergências básicas entre os dois grupos, simbolizando "a pedra de toque em torno da qual todas as outras questões confluíram" (Gomes, 1980: 29).

O processo de construção e consolidação de um arcabouço burocrático-institucional no âmbito da saúde pública, nesse período, defrontou-se, portanto, com essas alterações na composição de poder entre o governo federal e os poderes locais, decorrentes da gradativa configuração de um regime centralizado, ainda que com um formato diverso do apresentado no Império. Logo, os objetivos delineados para a política social de saúde estariam imersos nessas relações políticas, econômicas e sociais a que se referem os autores mencionados. Ela será delineada a partir das alterações nessa composição de interesses entre coronéis, burocracia pública, governadores estaduais e governo central, conforme os novos arranjos de poder instituídos. Não é por acaso que um dos temas mais freqüentes nos debates relativos aos serviços de saúde a partir de 1935 diz respeito à normatização da relação entre os estados e a União. Foi, portanto, nesse quadro de instabilidade política, em que Getulio Vargas buscava mecanismos para se consolidar no poder reforçando os ideais de construção de um Estado nacional centralizador e intervencionista, que transcorreram os primeiros anos de seu governo. Gradativamente foram sendo definidos um novo modelo de gestão para a saúde em todo o país e as estratégias para sua implementação, 
HISTÓRIA DA SAÚDE NO RIO DE JANEIRO

processo de reforma institucional que acompanhou os diferentes contextos políticos que marcaram os 15 anos do governo Vargas.

\section{Mudanças na Área da Saúde: reorganização institucional}

A primeira mudança de impacto na estrutura institucional da saúde ocorreu ainda em 1930, quando foram criados o Ministério da Educação e Saúde Pública (Mesp) e o Ministério do Trabalho, Indústria e Comércio (MTIC). Em sua dimensão institucional, as ações públicas de saúde acompanharam as distinções estabelecidas entre MTIC e o Mesp. De um lado, estabeleceu-se o arcabouço jurídico e material da assistência médica individual previdenciária, desenvolvida no MTIC, que com o passar dos anos se tornaria uma das principais referências para a prestação de serviços públicos de saúde. Tal assistência era destinada aos inseridos no mercado formal de trabalho e amparada por princípios corporativos que definiam aqueles reconhecidos como cidadãos, caracterizando o que Wanderley Guilherme dos Santos (1998) denominou de "cidadania regulada". De outro lado, no Mesp, atrelada à educação, ficou a saúde pública. Ou melhor, tudo o que dissesse respeito à saúde da população e que não se encontrasse na área de abrangência da medicina previdenciária. Ao Mesp cabia a prestação de serviços para aqueles identificados como précidadãos: os pobres, os desempregados, os que exerciam atividades informais, ou seja, todos aqueles que não se encontravam habilitados a usufruir os serviços oferecidos pelas caixas e pelos institutos previdenciários. ${ }^{2}$ Essa seria a nova configuração da atuação federal na área da saúde, no âmbito da qual estariam as ações de assistência médica.

Em janeiro de 1931 foi regulamentada a nova estrutura organizacional do Mesp, definindo-se que, além de uma secretaria de Estado, o novo ministério seria formado por sete repartições ${ }^{3}$ e quatro departamentos nacionais independentes entre si: Ensino, Saúde Pública, Medicina Experimental e Assistência Pública. Apesar de três deles serem concernentes à área da saúde, a sua constituição não implicou de imediato alterações substantivas no quadro institucional vigente. Mudanças efetivas nesse setor só ocorreriam gradativamente nos anos seguintes, acompanhando as substituições ministeriais.

O Departamento Nacional de Medicina Experimental seria formado pelo Instituto Oswaldo Cruz (IOC) e por eventuais instituições que fossem criadas para desenvolver atividades congêneres. Entretanto, o departamento permaneceu restrito ao IOC, que em outubro de 1932 recuperou sua denominação original. O Departamento Nacional de Assistência Pública abarcou os serviços de assistência hospitalar e sua direção esteve a cargo de Pedro Ernesto Batista. Existiu como departamento somente até outubro de 1931, quando se transformou em uma diretoria do Departamento Nacional de Saúde Pública (DNSP). Porém, dois meses depois, em 30 de dezembro de 1931, sua diretoria foi extinta devido à supressão do fundo especial destinado à assistência hospitalar e ao conseqüente desprovimento de recursos para a ampliação dos serviços de assistência pública de abrangência nacional. Os hospitais que dele faziam parte, São Francisco de Assis e Pedro II, permaneceram subordinados ao DNSP (decreto 20.890, 30 dez. 1931). ${ }^{4}$ Ainda conforme o regulamento de janeiro de 1931, o DNSP não sofreria alterações naquele primeiro momento, confirmando-se o que decretos anteriores já haviam indicado. Ou seja, o departamento foi incorporado ao Mesp a partir de novembro de 1930 preservando-se sua organização e assegurandose sua autonomia como órgão responsável pelas ações de saúde pública. Sua estrutura era composta por 
três diretorias: dos Serviços Sanitários do Distrito Federal; de Defesa Sanitária Marítima e Fluvial; e de Saneamento e Profilaxia Rural. (Atente-se para o fato de o Distrito Federal apresentar sempre uma estrutura própria, diferentemente dos outros estados.)

As divergências sobre o futuro político do país repercutiriam também no futuro do recém-criado ministério. O formato institucional a ele atribuído deveria obviamente ser compatível com o projeto político vitorioso nas disputas desencadeadas no pós-1930. Porém, tal como os debates que ocorriam na esfera política nacional, os primeiros anos do Mesp foram marcados pela indefinição e inconstância de propostas e projetos. Uma das evidências dessa indefinição política encontra-se na alternância de ministros à frente do órgão, que em seus quatro primeiros anos foi conduzido sucessivamente por Francisco Campos, Belisário Pena e Washington Pires. ${ }^{5}$

Este último, tão logo assumiu o cargo, empenhou-se em implementar mudanças que refletissem uma nova estratégia de ação pública para a saúde e apresentou uma proposta que implicava mudanças no DNSP e criava a Diretoria Nacional de Saúde e Assistência Médico-Social (DNSAMS), a qual foi aprovada em junho de 1934, apenas um mês antes da promulgação da nova Constituição. Com pequenas variações, a maioria dos serviços que compunham o DNSP permaneceu na nova estrutura, mas reagrupados em duas grandes seções técnicas gerais de Saúde Pública e Assistência Médico-Social, e em cinco novas diretorias: de Defesa Sanitária Internacional e da Capital da República; de Serviços Sanitários nos Estados; de Proteção à Maternidade e à Infância; de Assistência a Psicopatas e de Profilaxia Mental; e de Assistência Hospitalar. ${ }^{6}$ Esta última incorporava em sua estrutura organizacional os seguintes órgãos: Centro de Assistência e de Triagem; Hospital São Francisco de Assis; Hospital Pedro II; Preventório Paula Candido; Hospital-Colônia de Curupaity. A Diretoria Sanitária Internacional e da Capital da República passou a apresentar a seguinte estrutura: Inspetoria da Marinha Mercante e dos Portos, Inspetoria dos Centros de Saúde, Inspetoria da Fiscalização do Exercício Profissional, Inspetoria de Alimentação, Laboratório de Saúde Pública, Hospital de Isolamento São Sebastião e Escola de Enfermagem Anna Nery. ${ }^{7}$

O novo desenho institucional expunha as prioridades em curso no novo governo ao enfatizar a criança, a área de saúde mental, a assistência médico-hospitalar e a expansão e o reforço da presença do governo federal nos estados, em resposta às demandas de não mais concentrar no Distrito Federal os serviços federais de saúde. De acordo com João de Barros Barreto - importante líder na área da saúde e futuro diretor do Departamento Nacional de Saúde (DNS) -, foi de fato a partir de 1934, com a regulamentação do novo órgão, que se iniciou de forma coordenada a expansão dos serviços para além do Distrito Federal:

Mas só em 1934 positivou-se o início de reestruturação que vinham exigindo os progressos da técnica de organização sanitária e a situação brasileira, a impor de maneira formal que não mais se concentrassem no Rio de Janeiro as iniciativas do governo da União. Instituiu-se, assim, naquele ano um órgão técnico de comando para vários serviços do setor saúde, dispersos dentro do novo ministério. Deu-se, pela primeira vez, uma direção especializada aos hospitais gerais mantidos pela União; remodelou-se, fundamentalmente, a organização sanitária do Distrito Federal, instituindo-se o sistema moderno e ideal dos Centros de Saúde; e estendeu-se a ação federal aos Estados. (Barreto, 1942b: 170)

Ao findar o Governo Provisório o Mesp se encontrava, portanto, no início de um processo de reestruturação administrativa, sem o tempo de vigência necessário para sua consolidação. O quadro 
de instabilidade e substituições no cargo ministerial que caracterizara os quatro primeiros anos de existência do ministério mudaria substantivamente a partir de julho de 1934, quando Gustavo Capanema tomou posse como o novo e principal gestor da área de educação e saúde. Capanema herdava a recém-aprovada estrutura legada por Washington Pires, afirmando que ela havia sido importante por ter reorganizado os serviços de assistência hospitalar, que inicialmente tiveram relevância secundária, e ampliado a atuação do Mesp na área da assistência social. O ministério ficou constituído então por três ordens de serviço: a educação nacional, a saúde pública e a assistência social (Arquivo Gustavo Capanema/Cpdoc/FGV, GC 34.06.21, F 07).

Com Gustavo Capanema tem início um novo momento na história institucional da saúde no país, e uma série de reformas será implementada, consolidando uma nova estrutura administrativa para a saúde pública, que perdurará, com poucas alterações, até a criação, em 1953, do Ministério da Saúde. As mudanças que o novo ministro propunha, em projeto apresentado em novembro de 1935, alterariam a estrutura institucional definida pela recente reforma de Washington Pires, aprovada em junho de 1934. Durante o ano de 1935, enquanto o novo projeto de reforma era elaborado, as principais atividades empreendidas na área da saúde se dividiram entre aquelas definidas pela nova estrutura da DNSAMS e as mudanças em curso nos serviços do Distrito Federal. Na capital da República destacou-se a criação dos centros de saúde - que absorveram os serviços das antigas Diretoria dos Serviços Sanitários do Distrito Federal e Diretoria de Saneamento Rural - e das inspetorias especializadas. No final de 1935 a cidade fora dividida em 12 distritos, que já contavam com nove centros de saúde. ${ }^{8}$

Tanto a exposição de motivos que acompanhou o projeto enviado à Presidência da República como o próprio projeto de lei reafirmavam duas orientações com respeito à ação federal nos estados. Por um lado mantinham a conduta adotada no Brasil havia várias décadas, que delegava à União uma função supletiva, com participação centrada em auxílios financeiros aos órgãos públicos e privados de saúde por meio de convênios firmados com os estados. A ação direta seria exercida apenas em casos de endemia ou epidemia de extensões graves, quando a administração estadual não reunisse condições de combatêla, o que evidencia a preocupação em preservar a autonomia local. Em sua exposição de motivos, Capanema expressava a visão predominante com relação a esse ponto, deixando clara sua intenção de resguardar a área de atuação dos estados e, assim, evitar eventuais atritos políticos e gerenciais, afirmando que a ação supletiva da União deveria ser, em regra, indireta (Capanema, 1935). O ministro defendia, entretanto, posição diversa com relação à capital da República quando afirmava:

De fato, não é de mero interesse local, mas é sobretudo de interesse nacional que a cidade, que é a sede dos órgãos da soberania nacional, que é o centro de toda a vida política da nação, que é o ponto de residência dos representantes das nações estrangeiras, tenha a sua defesa sanitária, provida de todos os recursos, sob a direta responsabilidade da União. A esta deve caber organizá-la, custeá-la e dirigi-la. Com a saúde pública se dá o mesmo que com a polícia. No Distrito Federal, é tarefa da União. (Capanema, 1935: 23)

Essa linha de interpretação, que ressaltava as especificidades do Distrito Federal quando se tratava de definir atribuições e modelos de prestação de serviços de saúde, iria aparecer também nos debates que ocorreram durante o processo de votação da Reforma Capanema. 


\section{Serviços de Saúde do Distrito Federal no Debate da Reforma Capanema}

Com relação aos serviços de saúde do Distrito Federal, três pontos centralizaram o debate sobre o artigo 56 da lei, no qual ficavam definidas as atividades sanitárias a serem executadas pelo Serviço de Saúde Pública do Distrito Federal. ${ }^{9}$

O primeiro deles tratava de um antigo tema de discussão: a forte concentração dos serviços federais na capital da República em detrimento das outras regiões do país. Em discurso pronunciado na sessão do dia 15 de dezembro de 1936, o deputado Agostinho Monteiro criticou a aplicação quase integral das verbas da saúde pública no Distrito Federal, tendo por base o orçamento de 1933. Defendeu também que se priorizasse a assistência médica. Os deputados Xavier de Oliveira e Lino Machado corroboraram suas observações, mas criticaram o modelo instituído por Carlos Chagas, que havia, segundo eles, relegado a segundo plano a assistência médico-hospitalar. Xavier de Oliveira argumentava:

é um erro que se repete agora, erro cometido quando foi da criação do DNSP com Carlos Chagas, época em que foi instituída também a profilaxia rural. Então era a profilaxia, como se diz, o Leitmotiv dos sanitaristas para o Brasil naquele tempo, esquecida inteiramente a assistência hospitalar. (Diários do Poder Legislativo, 18 dez. 1936: 23.623)

A argumentação dos deputados se detinha na relação entre saúde pública e assistência médica e no pressuposto de um antagonismo entre essas áreas, como se a prioridade sobre uma levasse necessariamente ao abandono da outra. Na interpretação dos deputados, investir em saúde pública significava esquecer a assistência médica, como se não fosse viável compatibilizá-las em um serviço público de saúde.

No momento em que se definia uma nova estrutura para a saúde pública essa questão surgiu vinculada à discussão sobre a interferência ou não do governo central nos estados. Nesse caso a autonomia dos serviços estaduais de saúde apresentava peculiaridades: tratando-se de ações a serem realizadas na capital da República, era difícil distinguir entre competências federais e locais. ${ }^{10}$

O segundo ponto que sobressaiu nos debates relativos aos serviços do Distrito Federal dizia respeito à polêmica entre a adoção do modelo distrital, representado pelos centros de saúde, e a preservação da organização existente até então, com base em inspetorias especializadas.

Segundo Raul de Almeida Magalhães - diretor do DNSP na gestão de Washington Pires -, em exposição feita à Comissão de Saúde Pública, havia duas correntes de orientação da moderna saúde pública: uma que criticava os serviços técnicos baseados em inspetorias autônomas e recomendava o sistema distrital, organizado em centros de saúde que concentrassem todas as atividades; e outra que reconhecia a importância dos centros de saúde, mas não os considerava incompatíveis com o sistema de inspetorias. Defendendo a segunda corrente, lembrou que a tendência moderna era a especialização e que o inspetor dos centros de saúde, responsável no regime distrital pela orientação de todas as atividades sanitárias, não poderia dominar conhecimentos tão diversos, de tantas especialidades. Ao mesmo tempo, por acreditar que determinadas atividades de saúde pública não deveriam figurar nos centros de saúde, defendeu a autonomia do serviço de doenças transmissíveis sob uma única direção: "Com o serviço fracionado em 10 centros por escassez de pessoal habilitado e por falta de condução, não podem as notificações de doenças transmissíveis serem atendidas com a indispensável presteza" (Organização da saúde pública, 14 jun. 1936). 
Acentuando mais uma vez que o regime de centros de saúde não excluía a necessidade de inspetorias, descreveu o sistema distrital adotado em Nova York, que possuía naquela época um diretor e subdiretor de saúde, com inspetorias nos seguintes campos: administração geral, enfermagem, higiene infantil, doenças transmissíveis, tuberculose, doenças venéreas, política sanitária, alimentos e drogas, e laboratórios. Os diretores dos centros de saúde seguiam orientações das inspetorias especializadas, e as autoridades distritais eram meras executoras dos serviços a receber orientação técnica das inspetorias.

Prevaleceu na estrutura aprovada com a reforma e em seus desdobramentos nos anos seguintes um modelo conciliador que confirmaria as observações de Raul de Almeida Magalhães. Os centros de saúde se consolidaram como modelo de referência na organização sanitária - não só no Distrito Federal, mas em todo o país -, constituindo o ápice de uma hierarquia formada por postos de saúde e subpostos, classificados conforme a complexidade das atividades desenvolvidas e o perfil dos profissionais que neles atuavam. As inspetorias, por sua vez, foram aos poucos dando lugar aos serviços especializados, que também cresceram e se expandiram, principalmente após a criação dos serviços nacionais em 1941, confirmando a interpretação de que o modelo distrital não era incompatível com uma estrutura de serviços especializados.

O terceiro ponto de destaque nos debates sobre a área da saúde no Distrito Federal referia-se à criação ou não de um serviço autônomo para a área materno-infantil, que já vinha se configurando como um campo especializado de ação pública. O papel de destaque e a relevância atribuídos aos serviços de atenção materno-infantil na estrutura administrativa do Estado foram também motivo de críticas e divergências. Para alguns profissionais eles deveriam ser da alçada dos centros de saúde; para outros era absurdo concentrar em um mesmo espaço crianças e portadores de doenças transmissíveis.

A polêmica prosseguiu em várias sessões da Câmara e reuniões das comissões, refletindo concepções diversas sobre as atividades dos centros de saúde, a importância destes como um espaço de profilaxia e educação sanitária e enfatizando as distinções entre as suas atividades e aquelas da assistência médica clínica. Provocou também observações sobre a doença contagiosa e suas diferenças em relação às doenças transmissíveis. A forma final do texto da lei mostra que prevaleceu a opinião de que os serviços maternoinfantis mereciam uma diretoria específica. A criação da Diretoria de Assistência Materno-Infantil fortaleceria institucionalmente a área, que se tornou um dos alvos prioritários da política social do governo Vargas, ampliando seu âmbito de atuação para além do Distrito Federal. Essas diretrizes se confirmariam com a criação, em 1940, do Departamento Nacional da Criança (DNCr), com o mesmo nível hierárquico do DNS, o que assegurou maior abrangência e autonomia de gestão à área materno-infantil. ${ }^{11}$

\section{O Novo Modelo a partir de 1937}

Em 13 de janeiro de 1937 entrou em vigor a nova lei que reorganizava a estrutura do agora denominado Ministério de Educação e Saúde (MES). As mudanças propostas no projeto de reforma especificavam basicamente três grandes áreas de serviços da saúde pública. Na lei sancionada em 1937, a seção relativa a esses serviços distinguia-os da seguinte forma: aqueles dedicados à investigação, os serviços de saúde do Distrito Federal e os de abrangência nacional. Esse formato explicitava a lógica que orientou a organização administrativa do campo da saúde pública, separando os serviços da capital da República daqueles destinados aos demais estados da federação. 
Os artigos que regulamentavam especificamente as atividades e serviços do Distrito Federal indicavam que eles passaram a se organizar por intermédio do Serviço de Saúde Pública do Distrito Federal e do Serviço de Assistência Hospitalar do Distrito Federal. O primeiro incorporava os seguintes órgãos: Laboratório de Saúde Pública; Inspetoria da Alimentação; Inspetoria dos Centros de Saúde; Inspetoria dos Serviços Especiais e Inspetoria de Engenharia Sanitária. O segundo, destinado a suprir as necessidades de assistência hospitalar no Distrito Federal, ficou constituído pelo Hospital Estácio de Sá, o Hospital São Francisco de Assis e o Hospital Pedro II. Um parágrafo único indicava a criação de um Centro de Cancerologia, destinado à profilaxia e ao tratamento do câncer (Brasil, 1937, lei 378).

A mesma lei delegava ao DNS a incumbência de administrar as atividades de saúde pública no Brasil. Estabeleceu-se então que este órgão seria composto de quatro divisões: de Saúde Pública; de Assistência Hospitalar; de Assistência a Psicopatas e de Amparo à Maternidade e à Infância. À Divisão de Assistência Hospitalar foi delegada a responsabilidade pela direção dos serviços relativos à assistência hospitalar, de caráter nacional, como também os de caráter local, que fossem executados pela União. O artigo 54 da mesma lei criou também o Instituto Nacional de Puericultura, com o objetivo de realizar estudos, inquéritos e pesquisas sobre os problemas relativos à maternidade e à saúde da criança. ${ }^{12}$

João de Barros Barreto foi nomeado seu diretor, tornando-se o colaborador direto de Capanema na gestão dos assuntos referentes à saúde. A partir daí, teve início um período de intenso trabalho normativo com elaboração de leis, regulamentos e códigos sanitários, que objetivavam padronizar as atividades dos diversos serviços de saúde nos estados em seus mínimos detalhes, acompanhando o processo de burocratização do Estado, que se intensificava. As novas diretrizes adequavam-se em muitos aspectos às propostas que vinham sendo debatidas em fóruns internacionais, preconizadas e aplicadas em particular nos Estados Unidos, incorporando as prioridades definidas para a ação pública em saúde pela agenda dos congressos e conferências patrocinados pela Organização Pan-Americana da Saúde (Opas). Estabeleceuse um padrão de atuação pública que combinava centralização normativa e descentralização executiva, canalizando para a instância administrativa estadual o gerenciamento dos serviços públicos de saúde, sob a orientação do governo central.

O fortalecimento da instância estadual como lócus de controle político era tão evidente que, entre as medidas previstas para a implantação do sistema distrital, mais especificamente na regulamentação das atribuições, o governo central aventava a possibilidade de não existirem serviços de saúde mantidos por municípios. Tal orientação não prescindiria, entretanto, da participação destes nos custos financeiros de implantação e manutenção dos serviços de saúde. Reproduzindo o modelo de Caixas de Fundos instituídas em 1938 no Rio de Janeiro, durante a gestão de Mário Pinotti no Departamento de Saúde do Distrito Federal, os municípios deveriam contribuir com 5\% de toda a receita arrecadada para os serviços de assistência e saúde pública. Esse modelo seria tomado como referência padrão para o restante do país, definindo a modalidade de financiamento na nova forma de gestão em saúde pública (cf. decretos publicados respectivamente em 31 de dezembro de 1937 e 26 de abril de 1938, apud Barreto 1938).

Quatro anos depois, em 1941, já sob o regime do Estado Novo, Gustavo Capanema complementaria as mudanças que iniciara em 1937, realizando importantes alterações no DNS no sentido de centralizar ainda mais a participação federal na gestão da saúde. Dessa vez prescindindo da participação do Congresso, fechado desde novembro de 1937, quando da instauração do governo ditatorial. Nesse momento foram 
criados os serviços nacionais e duas novas divisões - a Divisão de Organização Sanitária (DOS) e a Divisão de Organização Hospitalar (DOH) -, que incorporaram funções até então desempenhadas pelas antigas divisões de Saúde Pública e de Assistência Hospitalar do DNS. Com essa reorganização as divisões também ampliaram seu raio de ação, caracterizando-se como "elementos norteadores da estruturação geral das repartições de saúde no Brasil” (Barreto, 1942b: 174).

\section{As Atividades da Divisão de Organização Hospitalar}

Assim como a DOS, a DOH foi criada com objetivos de padronização, normatização e controle das ações relativas à assistência médico-social em todos os estados do país. Constituiu, assim, os 'braços' da gestão federal nos estados no campo hospitalar. Sob a direção do médico Teófilo de Almeida, era composta das seções de Edificações e Instalações, Organização e Administração e Assistência e Seguro de Saúde.

Suas atribuições, em face das prioridades da área, foram debatidas durante a realização da $1^{\mathrm{a}}$ Conferência Nacional de Saúde, realizada em 1941, quando se definiram como diretrizes para o setor: a criação de hospitais regionais, ambulatórios e postos de socorro de urgência segundo o sistema de divisão distrital; o atendimento às exigências mínimas, nas zonas rurais, de dois leitos por mil habitantes para os hospitais gerais e um médico para cada quatro mil habitantes. No decreto de 1942 que regulamentou as funções da DOH incluíam-se, entre outras, a determinação de organizar um plano geral de assistência, nele compreendido uma rede de hospitais para todo o território nacional; estabelecer normas e padrões para instalação, organização e funcionamento dos vários serviços técnicos e administrativos de hospitais de diversos tipos; organizar e manter atualizado um cadastro dos estabelecimentos hospitalares no país. ${ }^{13}$

Em seu primeiro ano de atividades, a DOH dedicou especial atenção à realização de um cadastro hospitalar em todo o país, com questionário minucioso que abarcava informações "do mais completo hospital à mais modesta casa de caridade" (Barreto, 1942a: 79). O total de estabelecimentos conhecidos em todos os estados era de 1.173, e foram cadastradas, durante o ano de 1941, 358 instituições. Realizado entre novembro de 1941 e novembro de 1942, foi o primeiro em todo o Brasil com tal objetivo. Nele os dados referentes ao Distrito Federal informam que à época a cidade contava com 84 estabelecimentos, dos quais foram cadastrados $59 .{ }^{14}$

As informações obtidas com o cadastro foram o ponto de partida para a construção de uma rede nacional de hospitais regionais que visava a atender ao problema da assistência médico-cirúrgica. A rede deveria integrar os recursos da União, dos estados e municípios, e contaria também com a colaboração da iniciativa privada, de sociedades beneficentes, organizações mutuárias, além de institutos e caixas subordinados ao Ministério do Trabalho, Indústria e Comércio, empresas industriais, estabelecimentos rurais e, em destaque, a Cruz Vermelha Brasileira. A política de saúde destinada à área hospitalar voltouse, a partir de então, para a elaboração de um plano destinado à criação de uma rede brasileira de hospitais, a começar pelos estados do Norte e Nordeste. O plano abrangia hospitais gerais e especializados, exceto os destinados a maternidade, doenças mentais, tuberculose e lepra, que já possuíam planos especiais elaborados pelos serviços federais correspondentes. Ele ganhou caráter prioritário para o ano de 1942, tendo em vista a participação brasileira no contexto de guerra internacional. 
Em novembro desse mesmo ano foi enviada ao ministro da Educação e Saúde uma nota expositiva sobre a proposta de construção de uma rede brasileira de hospitais, em que se esclareciam os parâmetros que norteariam sua configuração. Destinava-se, inicialmente, aos estados do Norte e Nordeste, compreendidos do estado do Pará até o de Sergipe. Em seu item 9, indica:

O que interessa ao aparelhamento da assistência médico-cirúrgica, parte integrante da organização nacional, não é só o leito de caridade ou para indigentes, mas leitos convenientes ou disponíveis para atender todas as camadas sociais, com a cooperação, orientação geral técnica e controle do Estado. Merecem sob este ponto de vista, igual atenção os leitos gratuitos e os de indústrias, de cooperativas ou irmandades, e mesmo os destinados a contribuintes, isto é, os de finalidade não-lucrativa e os de finalidade lucrativa: estes últimos aliviam as despesas dos primeiros e o grave ônus da obrigação federal, estadual e municipal, naquilo que, de previdência e assistência social, compete aos governos, quando falha a contribuição privada. (Barreto, 1943: 179, grifo meu)

A proposta revela qual o perfil definido para a atribuição estatal, no momento em que havia, por parte dos gestores públicos, uma demanda formal para que o Estado reconhecesse como sua obrigação prestar serviços de assistência médica sem discriminação de grupos sociais. A execução do plano ficaria sob a supervisão da $\mathrm{DOH}$, cuja orientação técnica baseava-se em princípios preconizados por organizações americanas como o Colégio Americano de Cirurgiões e a Associação Americana de Hospitais, que definiam a organização hospitalar como uma especialização. Esses princípios contribuíram para que a DOH difundisse o que considerava ser uma consciência hospitalar moderna. A influência americana sobre o formato proposto para a política pública de saúde na área hospitalar pode ser atribuída, a princípio, à visita do diretor da DOH Teófilo de Almeida aos Estados Unidos, realizada durante seus três primeiros meses no cargo, e aos interesses e necessidades decorrentes da conjuntura de guerra internacional.

Simultaneamente às medidas de execução do plano da Rede Brasileira de Hospitais, o ministro Gustavo Capanema apresentou anteprojeto de decreto-lei que estabelecia normas e princípios gerais para regular os serviços de assistência médico-social no país. $\mathrm{O}$ artigo $1^{\circ}$, que definia sua finalidade, determinava:

Fica instituído para todo o país o controle da assistência médico-social a doentes, deficientes físicos e desamparados, no sentido da sistematização técnica desse serviço, visando a criação de uma rede nacional de instituições hospitalares e de assistência social, convenientemente aparelhadas para atender, segundo as necessidades locais e regionais, toda a população do Brasil. (apud Barreto, 1943: 186, grifo meu)

O anteprojeto estabelecia também normas e princípios para a classificação e o funcionamento dos estabelecimentos hospitalares e para-hospitalares, preocupando-se em assegurar que a padronização e supervisão dessas diretrizes em todo o país estivessem a cargo da DOH. A classificação definia uma série de distinções que incluíam o número de leitos, o padrão e a capacidade física das edificações, o tipo de clínica, o tipo de propriedade e sua manutenção (oficiais, filantrópicas e particulares) e as especificidades de sua direção e administração. Seguia aqui a DOH a mesma estratégia adotada no âmbito da DOS, ao procurar padronizar as diversas modalidades de prestação de serviços, como pode ser observado no Anexo 2.

Nos primeiros anos da década de 1940, além do investimento na regulamentação e no controle das atividades hospitalares, concentrado principalmente na coleta de informações para alimentar o cadastro hospitalar e na constituição de uma rede de hospitais, a DOH se dedicou também à formação de quadros profissionais para o setor. Em 1943 realizou-se, pela primeira vez no Brasil, um curso de organização e 
administração hospitalares conduzido pelo diretor da divisão e alguns de seus técnicos. O curso foi mantido nos anos seguintes, pois em 1944 Barros Barreto (1945) relatava que o Brasil tinha a primazia de realizar para toda a América Latina, havia dois anos, o ensino de especialização e aperfeiçoamento em organização e administração hospitalares.

À semelhança de outros setores que foram alvo de políticas públicas, as ações de assistência médica no âmbito do MES foram marcadas pela preocupação em construir um serviço efetivamente nacional e articulado, sob orientação centralizada e com normas gerais padronizadas. Embora aqui não sejam abordadas em detalhes, pode-se mencionar, a título de exemplo, o processo gradativo de profissionalização e especialização - acompanhando portanto as atividades específicas da saúde pública - por meio da realização de cursos em administração hospitalar, formação de técnicos e especialização de enfermeiras. Criaram-se também as bases para a implantação efetiva de um sistema de assistência hospitalar em todo o país, com as especificidades que lhe eram pertinentes. Ou seja, medidas efetivas para organizar nacionalmente os serviços foram tomadas, com o intuito de institucionalizar e consolidar a área de assistência médica. E o que é muito importante: com características abrangentes, não restritivas, explicitamente destinadas a toda a população brasileira. Assim, esse campo de atuação pública se institucionalizou como um serviço universal e, associado aos serviços concernentes à DOS, almejava a constituição de uma ampla rede de assistência no âmbito da saúde pública, combinando medicina preventiva e curativa.

Dentro desse quadro geral, cabe agora observar de que forma os serviços de saúde do Distrito Federal interagiram com essas mudanças institucionais implementadas nas estruturas federais de saúde. Que transformações ocorreram nos serviços existentes na cidade, de que forma foi repensada a estrutura organizacional da assistência médica no Distrito Federal, quais as semelhanças e diferenças em relação ao modelo político-institucional que estava sendo adotado para o restante do país?

\section{A Saúde no Distrito Federal: construção e consolidação de uma herança institucional}

As mudanças na gestão da política de saúde no Distrito Federal a partir da década de 1930 estão intimamente relacionadas ao contexto político nacional e às diretrizes adotadas pelo governo federal para este setor de ação pública. Mas se associam também diretamente à atuação de Pedro Ernesto Batista, que assume a liderança política local, em conseqüência de sua participação direta no movimento revolucionário, sendo nomeado interventor no Distrito Federal, em seguida diretor da Assistência Hospitalar do Distrito Federal, e posteriormente eleito prefeito da cidade. Considerado um importante interlocutor entre o governo local e o governo federal, Pedro Ernesto demonstrou afinidade de princípios e diretrizes na condução da política de saúde adotada nesse período. Em discurso na solenidade de inauguração do Hospital Jesus, Pedro Ernesto explicitou essa afinidade de princípios e a preocupação em enfatizar a responsabilidade do Estado na prestação de serviços públicos: "Os rumos da revolução se afirmavam através da probidade administrativa, sede de justiça, reconhecimento da igualdade dos brasileiros e por uma expectativa angustiosa dos serviços públicos que ao Estado caberia prover para o bem-estar da coletividade" (Arquivo Cpdoc, apud Vieira, 1982: 326).

Com essa lógica política, sua administração seria marcada por uma intensa atividade na área da assistência médica, dando início à construção de um número elevado de hospitais e dispensários, alguns 
inaugurados ainda durante sua gestão, legando para a história da cidade do Rio de Janeiro uma significativa herança institucional na área da saúde. A assistência médica se destacou, assim, como um dos focos privilegiados de atuação pública, fortalecendo institucionalmente um modelo de prestação de serviços na área da saúde como atribuição do Estado, com ênfase na ação curativa, que se destinava à população em geral, sem restrições de acesso. A esse perfil de intervenção pública que formalizava a obrigação do governo de assegurar assistência médica a toda a população da cidade, contrapunham-se por outro lado os Institutos de Aposentadorias e Pensões (IAPSs), que, vinculados ao MTIC e inseridos no âmbito da previdência, iam também criando na cidade os seus hospitais destinados a prestar assistência médica aos seus segurados. ${ }^{15}$

Apesar dos conturbados acontecimentos políticos que levariam à saída de Pedro Ernesto e à sua prisão em 1937, o processo de reformulação na estrutura institucional da saúde prosseguiria, consolidando um modelo hierarquizado e regionalizado, que rompeu definitivamente com a lógica que até então havia privilegiado o pronto-socorro (Vieira, 1982). No ano seguinte, em 1938, a Secretaria Geral de Saúde e Assistência foi reorganizada, ${ }^{16}$ e em 1939 uma importante alteração jurídica fortaleceria ainda mais a autonomia institucional do Distrito Federal na área da saúde. Por meio do decreto-lei 1.040 (de 11 de janeiro de 1939), foram transferidas definitivamente para o Distrito Federal a manutenção e a administração dos serviços locais de saúde. Estavam assim constituídas as bases institucionais da assistência médica na cidade do Rio de Janeiro, pelas décadas seguintes. Mudanças significativas só iriam ocorrer nos anos 1950, em particular em 1953, com a criação do Ministério da Saúde, e em 1956, com as alterações no DNS e a criação do Departamento Nacional de Endemias Rurais (DNERu).

Isso porque, com a saída de Vargas do governo em 1945, a realização de eleições e a promulgação de uma nova Constituição em 1946, tem início um novo arranjo entre as forças políticas organizadas. No novo contexto, a política partidária assumiu pela primeira vez, a partir de 1946, um caráter nacional sem entretanto romper seus tradicionais vínculos históricos com a política local, marca de origem de nosso sistema político. O Distrito Federal preservava suas especificidades de capital da República, conciliando sua força política local com os interesses nacionais. A área da saúde estaria envolvida nesse jogo político, fato que pode ser observado no processo de criação do Ministério da Saúde.

O primeiro titular da pasta da Saúde, nomeado por Getulio Vargas em dezembro de 1953, foi Miguel Couto Filho, que tinha como credenciais o fato de ser filho de renomado médico e aliar a trajetória profissional ao desempenho na vida pública, dupla atuação que o habilitava a transitar na esfera do jogo da política partidária. E a imprensa da época ressaltou que sua indicação teria sido fruto do acordo político entre Vargas e Ernani do Amaral Peixoto, líder do Partido Social Democrático (PSD) fluminense, que pretendia ver seu afilhado político no posto de próximo governador do estado. A articulação política visando a fortalecer a candidatura de Miguel Couto Filho, construída em torno de interesses mais imediatos do PSD fluminense, se apoiou nas relações e acordos históricos do partido e de Amaral Peixoto com Getulio Vargas. Ou seja, as forças políticas regionais vinculadas ao estado do Rio de Janeiro demonstraram que mantinham a capacidade de articulação e de interferência sobre o jogo político nacional, direcionando os resultados segundo seus interesses e, neste caso, com repercussão direta sobre a área da saúde. ${ }^{17}$

A história institucional da saúde no Rio de Janeiro não pode, portanto, ser observada e analisada sem que se compreendam suas peculiaridades e especificidades concernentes ao fato de que era esta 
cidade, a capital da República, o centro do poder político nacional. Ela não era somente espaço de atuação pública, de intervenção do governo e criação institucional; era também palco do debate político, cenário do processo de decisão, onde se travavam as disputas políticas nacionais e celebravam-se os acordos. Essa configuração, entretanto, sofreria nas décadas seguintes o impacto da criação de Brasília e da transferência do centro do poder político para o interior do país.

E a partir daí, nesse novo contexto, as relações institucionais vão gradativamente sendo alteradas. A política de saúde local enfrentaria o desafio de responder (ou não) às demandas da população e acompanhar as diretrizes nacionais para o setor, só que agora, neste novo cenário, como mais um estado da federação e não mais com o status diferencial de capital federal. Para isso contaria com o extenso legado institucional que herdara dos períodos anteriores, os quais deveria manter de forma eficiente, com capacidade de adequação ao crescimento populacional, aos avanços da tecnologia e à complexidade do sistema médico assistencial. Trata-se ainda de um grande desafio a ser enfrentado.

Notas

${ }^{1} \mathrm{O}$ Rio Grande do Sul se manteria à parte, agindo como uma força rebelde e representando uma ameaça aos acordos realizados.

2 Para uma análise abrangente da história da assistência médica previdenciária, ver Oliveira \& Teixeira (1986).

${ }^{3}$ As sete repartições do Mesp eram: Inspetoria de Ensino Profissional e Técnico; Museu Nacional; Museu Histórico Nacional; Biblioteca Nacional; Casa de Rui Barbosa; Observatório Nacional e Inspetoria de Águas e Esgotos (decreto 19.560, 5 jan. 1931).

${ }^{4}$ Os serviços de assistência hospitalar abarcavam as seguintes instituições: Hospital São Francisco de Assis; Hospital Pedro II; Serviço de Assistência a Psicopatas (anteriormente subordinado ao Ministério da Justiça e Negócios Interiores); Hospital de Clínica e Inspetoria Geral de Hospitais (Gama e Silva \& Marques, 1955).

${ }^{5}$ A substituição no ministério obedeceu à seguinte seqüência: Francisco Campos (18 nov. 1930 a set. 1931); Belisário Pena (set. 1931 a dez. 1931); Francisco Campos (jan. 1932 a set. 1932) e Washington Pires (set. 1932 a jul. 1934).

${ }^{6}$ De acordo com a nova lei, a participação da União nos estados deveria ser feita por intermédio da Diretoria de Defesa Sanitária Internacional e da Capital da República e da Diretoria dos Serviços Sanitários nos estados.

${ }^{7}$ Cf. decreto 24.814, 14 jul. 1934, que estabelece o plano geral de organização dos serviços de saúde pública e assistência médicosocial, de acordo com o decreto 24.438, de junho de 1934.

${ }^{8}$ A criação dos centros de saúde foi definida pelo decreto 24.814, de 14 de julho de 1934 (ver também Arquivo Gustavo Capanema/ (pdoc/FGV).

${ }^{9}$ Esse serviço era composto, entre outros, pelos seguintes órgãos: Laboratório de Saúde Pública; Inspetoria de Alimentação; Inspetoria dos Centros de Saúde; Inspetoria dos Serviços Especiais (malária e peste) e Inspetoria de Engenharia Sanitária.

100 resultado desse embate pode ser observado na estrutura definida para o ministério em janeiro de 1937. A primeira proposta apresentada por Capanema argumentava a favor da transferência para o Distrito Federal dos serviços que, na época, encontravamse sob a responsabilidade da União. Conforme foi mencionado anteriormente, o ministro passou a defender em 1936, inversamente, a manutenção dos serviços da União nos estados, com o intuito de expandir a atuação federal. Entretanto, em 1939 os serviços foram transferidos para a Prefeitura do Distrito Federal, o que levou Barros Barreto a pedir demissão do cargo de diretor do DNS.

11 Para uma análise detalhada sobre o DNCr, ver Pereira (1992).

12 Uma vez instalado o Hospital das Clinicas da Universidade do Brasil, a Maternidade das Laranjeiras passará à alçada do Serviço de Puericultura do Distrito Federal. 
${ }^{13}$ As demais atribuições estipuladas para a DOH eram: "encarregar-se do estudo e solução de problemas referentes à assistência médico-social a doentes, deficientes físicos e desamparados; opinar nos processos de subvenção federal a instituições de assistência; cuidar dos problemas relativos à assistência médico-social a cegos e surdos-mudos, a indigentes, velhos, abandonados, aleijados e outros anormais, e deficientes físicos; organizar o plano nacional de seguro contra a doença e promover, em cooperação com a DOS, a instituição sistemática dos exames periódicos de saúde" (decreto 8.674, 4 fev. 1942).

${ }^{14}$ Segundo relatório apresentado por Barros Barreto (1943: 178) no ano seguinte, o cadastro foi executado exclusivamente por médicos oficiais que, em viagem a todos os municípios para a devida inspeção, visitaram as instituições e preencheram as fichas especiais. Ver Anexo 1.

${ }^{15}$ Entre as instituições criadas na gestão Pedro Ernesto, podemos citar: Hospital Regional Policlínica de Campo Grande (atual Rocha Faria); Hospital Regional Periférico de Marechal Hermes (atual Carlos Chagas); Hospital Periférico da Gávea (atual Miguel Couto); Hospital Jesus; Hospital Pedro Ernesto; Hospital Getulio Vargas; Dispensário de Campo Grande (atual Rocha Faria); Dispensário da Ilha (atual Hospital Paulino Wenerck); Dispensário do Méier (atual Salgado Filho); Dispensário do Sapê (atual Hospital Carmela Dutra); Dispensário de Paquetá (atual Hospital Manoel Arthur Villaboim); Dispensário Cascadura (atual Maternidade Estadual Herculano Pinheiro) (Vieira, 1982). No âmbito dos IAPSs foi o caso do Hospital dos Bancários (atual Hospital da Lagoa), dos Comerciários (atual Hospital de Ipanema e Cardiologia de Laranjeiras), dos Funcionários dos Transportes (atual Hospital de Bonsucesso) e dos Marítimos (atual Hospital do Andaraí), entre outros.

${ }^{16}$ Ficou então o Departamento de Assistência Hospitalar constituído pelos seguintes hospitais: de Pronto-Socorro, Carlos Chagas, Getulio Vargas, Miguel Couto, Jesus, dispensários de Cascadura, do Méier, do Governador, de Sapê, de Campo Grande, da Ilha de Postos de Vargem Grande, de Guaratiba e Serviço de Salvamento. Ver Brasil, decreto-lei 871 de 18 nov. 1938.

17 Para análise mais detalhada sobre a criação do Ministério da Saúde, ver Hamilton \& Fonseca (2003).

\section{Referências}

BRASIL. Decreto n. 24.438, de 21 de junho de 1934. Dispõe sobre a reorganização, sem aumento de despesa, da Secretaria de Estado de Educação e Saúde Pública e das repartições dependentes, e dá outras providências.

BRASIL. Decreto n. 24.814, de 14 de julho de 1934. Estabelece, na conformidade do decreto 24.438, de 21 de junho último, o Plano Geral de Organização dos Serviços de Saúde Pública e Assistência Médico Social, e dá outras providências, sem aumento de despesa.

BRASIL. Lei n. 378, 13 de janeiro de 1937. Dá nova organização ao Ministério da Educação e Saúde Pública.

BRASIL. Decreto-lei 871 de 18 de novembro de 1938.

BARRETO, J. B. Saúde pública no Brasil. Arquivos de Higiene, 8(2): 289-304, 1938.

BARRETO, J. B. As realizações do Departamento Nacional de Saúde em 1941. Arquivos de Higiene, 12(1), $1942 \mathrm{a}$.

BARRETO, J. B. A Organização da saúde pública no Brasil. Arquivo de Higiene, 12(2): 169-215, 1942b.

BARRETO, J. B. As realizações do Departamento Nacional de Saúde em 1942. Arquivos de Higiene, 13(1), 1943.

BARRETO, J. B. O Departamento Nacional de Saúde em 1943. Arquivos de Higiene, 14(1, 2), 1944a.

BARRETO, J. B. A V Conferência Pan-Americana dos Diretores Nacionais de Saúde. Arquivos de Higiene, 14(3): 183-200, 1944b.

BARRETO, J. B. As realizações do Departamento Nacional de Saúde em 1944. Arquivos de Higiene, 15(1, 2), 1945.

CAMARGO, A. et al. O Golpe Silencioso. Rio de Janeiro: Rio Fundo Editora, 1989.

CAPANEMA, G. Plano de Reorganização do Mesp Apresentado ao Poder Legislativo pelo Presidente da República. Rio de Janeiro: Imprensa Nacional, 1935.

DINIZ, E. O Estado Novo: estrutura de poder e relação de classes. In: FAUSTO, B. (Org.) História Geral da Civilização Brasileira. São Paulo: Difel, 1981. t. III, v. 3.

GAMA e SILVA, J. \& MARQUES, L. Evolução do Ministério da Educação e Saúde. Rio de Janeiro: Divisão de Pesquisas do Instituto Brasileiro de Administração/Fundação Getulio Vargas, 1955. 
GOMES, A. (Coord.) Regionalismo e Centralização Política: partidos e Constituinte nos anos 30. Rio de Janeiro: Nova Fronteira, 1980.

HAMILTON, W. \& FONSECA, C. Políticas, atores e interesses no processo de mudança institucional: a criação do Ministério da Saúde em 1953. História, Ciências, Saúde - Manguinhos, 10(3): 791-826, dez. 2003.

LIMA SOBRINHO, B. A Verdade sobre a Revolução de Outubro. 2. ed. São Paulo: Alfa-Ômega, 1975.

OLIVEIRA, J. \& TEIXEIRA, S. (Im)Previdência Social: 60 anos de história da previdência no Brasil. Petrópolis, Rio de Janeiro: Vozes, Abrasco, 1986.

ORGANIZAÇÃO da saúde pública. Jornal do Commercio, Rio de Janeiro, p. 6, 14 jun. 1936.

PEREIRA, A. Políticas Sociais e Corporativismo no Brasil: o Departamento Nacional da Criança no Estado Novo, 1992. Dissertação de Mestrado, Niterói: Departamento de História, Universidade Federal Fluminense.

SANTOS, W. G. Décadas de Espanto e uma Apologia Democrática. Rio de Janeiro: Rocco, 1998.

SCHWARTZMAN, S. As Bases do Autoritarismo Brasileiro. Brasília: Editora Universidade de Brasília, 1982.

VIANNA, L. W. Liberalismo e Sindicato no Brasil. Rio de Janeiro: Paz e Terra, 1976.

VIEIRA, P. Assistência Médica no Rio de Janeiro (1920-1937): reformas institucionais e transformações da prática médica, 1982. Dissertação de Mestrado, Rio de Janeiro: Instituto de Medicina Social da Universidade do Estado do Rio de Janeiro.

\section{Bibliografia complementar}

BARRETO, J. B. Normas para uma organização estadual de saúde pública. Arquivos de Higiene, 7(2): 339, 1937.

BARRETO, J. B. Medicina curativa em meio rural e suas relações com os serviços de saúde pública. Arquivos de Higiene, 9(1): 5-29, 1939.

HOCHMAN, G. A Era do Saneamento: as bases da política de saúde pública no Brasil. Rio de Janeiro: Hucitec, Anpocs, 1998.

HOCHMAN, G. \& FONSECA, C. A I Conferência Nacional de Saúde: reformas, políticas e saúde pública em debate no Estado Novo. In: GOMES, A. (Org.) Capanema: o ministro e o seu ministério. Rio de Janeiro: Editora FGV, 2000.

FONSECA, C. Saúde no Governo Vargas: dualidade institucional de um bem público. Rio de Janeiro: Editora Fiocruz, 2007.

SANTOS, W. G. Cidadania e Justiça: a política social na ordem brasileira. Rio de Janeiro: Campus, 1987.

SANTOS, W. G. O Ex-Leviatã Brasileiro: do voto disperso ao clientelismo concentrado. Rio de Janeiro: Civilização Brasileira, 2006. 
Anexo 1

Cadastro da Divisão de Organização Hospitalar

\section{FICHA DE INSTITUIÇÃO}

MINISTÉRIO DA EDUCAČ̃̃O E SAUDE DEPARTAMENTO NACIONAL DE SAUDE DIVISÃo DE ORGANIZAÇス̃o HOSPITALAR

FICHA N.

\begin{tabular}{llll}
\hline $\begin{array}{l}\text { ESTADO } \\
\begin{array}{l}\text { MUNICIPIO } \\
\text { DISTRITO }\end{array}\end{array}$ LOCALIDADE_ Nome da Instituiçio) & FUNDADA EM \\
\hline
\end{tabular}
DISTRTO

(Outras denominaç⿸s da instituiç̃o)

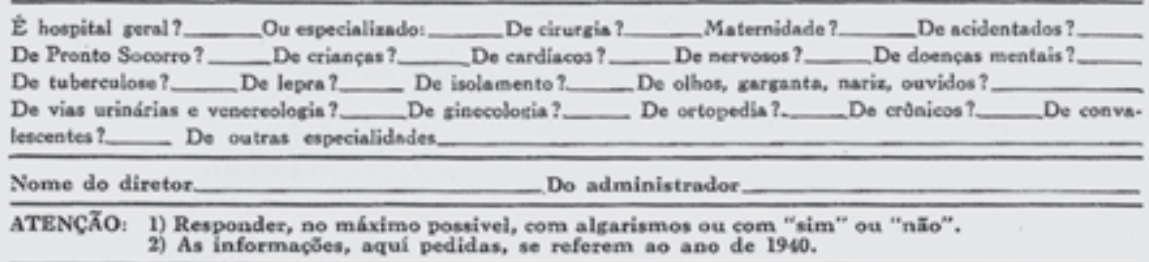

EDIricacöes $\mathrm{g}$ nestat.AçEs

E de construçĭo moderna? Na zona urbana? Tem parque? jardim? É do tipo "mono-bloco"? Ou tipo "pavilionar"? Quantos pavilhőes De quantos pavimentos? Quantas edificações anexas? Quantas enfermarias? Número de leitos? nas maiores? nas médià's? nas menores? Capacidade total de leitos nas enfermarias? Quantos quartos particulares? Total de leitos nos mesmos? Quantas salas de operaçăo? sépticas? assépticas? Quantas para anestesia? Para curativos? Para consul. tas? Para parto? Instalaçio de ortopedia? radiologia? sendo: para diagnós tico? para tratamento? Instalaçio para eletroterapia? hidroterapia? helioterapia? Para oto-rino-laringologia? oftalmologia? cardiologia? Quantos gabinetes dentários? Quartos para médicos-internos? Para estudantes? Para enfermeiros? Gabinete fotográfico? Farmácia? Com laboratório anexo? Laboratório clínico? bacteriológico? anátomo-patológico? sorológico? Tem necrotério? Sala de capela? Sala para leitura? Para cursos? Para reuniōes? Para projeção? Apare. lhos de "projeçĩo fixa"? de cinema $16 \mathrm{~mm}$ ? de $35 \mathrm{~mm}$ ? Quantos refeitórios para doentes ?

Para médicos e administraçlo?o? Para auxiliares e subalternos? Tem instalação elé. trica? de gás? de vapor? Aque- cimento interno? Refrigeradores elétricos? a gás? Câmaras frigorificas? Tem ar condicionado? Só filtrado? Esterilizado?

Há inter-comunicação telefônica? de alta voz? de sinal-som? de sinal-luminoso? Receptores de rádio? Rede interna de recepcão radiofónica? Há reservatório d'água? de quantos litros? A água é depurada? Quantas coxinhas? sendo dietéticas? Há lavandaria mecânica? Forno para incineraçăo de lixo? Quantos aparelhos sanitários? Destino do esgoto: rede geral? curso d'água? Fossa? O efluente da fossa é tratado? Clorado? Quantas ambulsncias? Elevadores? Carros térmicos para conduzir comida? Outros veículos? Há outras construçōes e instalaçŏes ?.......................... la

(Queiram juntar plantas, fotografias e quaisquer outros documentos referentes à instituição).

FUNCIONAMENTO E ADMINISTRAÇ̃̃o

Doentes internados em 1/1/40? Homens?

Mulheres? Crianças? Quantos. entrados durante 1940? Homens? Mulheres? Crianças? Quantos gratuitos em 1940? Homens? Mulheres? Crianças? Pensionistas ou contribuintes? Homens? Mulheres? Crianças? 


\title{
Anexo 2
}

Quadro de Classificação da Assistência Médica e Social em 1943

\section{DIVISÃO DE ORGANIZAÇÃO HOSPITALAR}

\author{
ASSISTÊNCIA MÉdica E SOCLAL
}

COMPREENDENDO: ASSISTENCIA HOSPITALAR E ASSISTENCIA PARA-HOSPITALAR

COORDENAÇ̃̃o COOPERAÇÃo ORIENTAÇ̃̃o CONTROLE

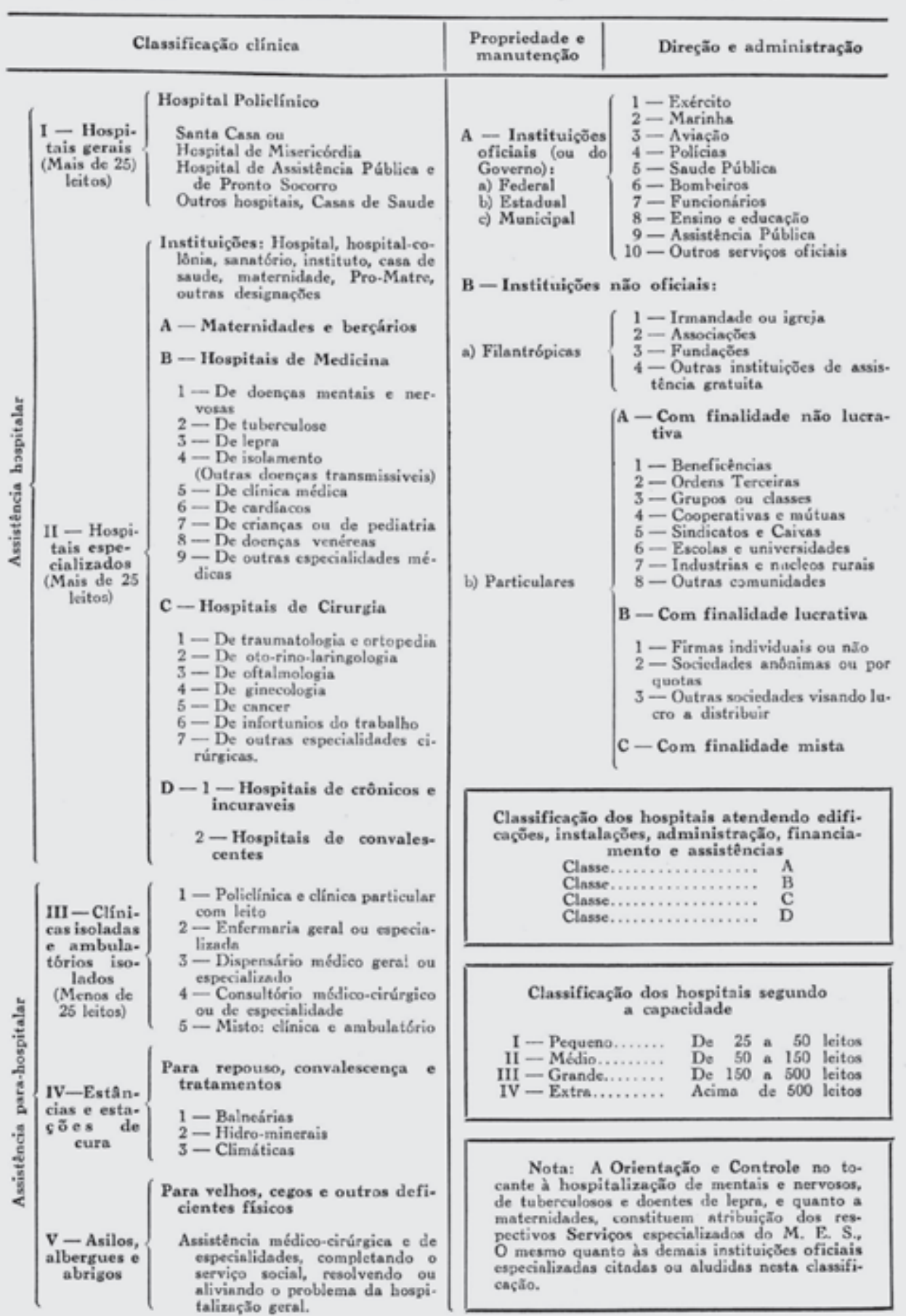

Fonte: Arquivos de Higiene, 13, 1943. 
Política e Saúde

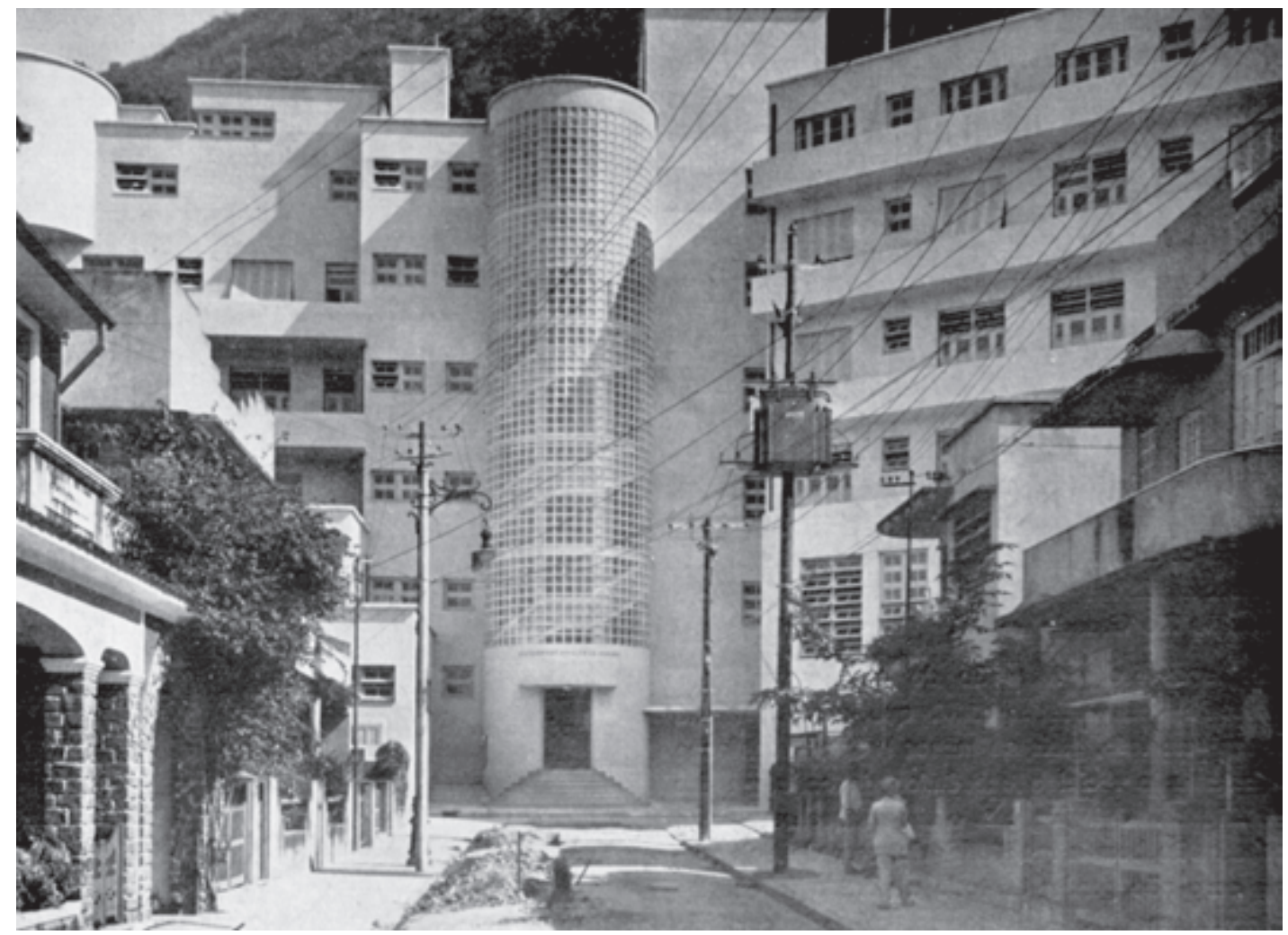

Maternidade Arnaldo

de Moraes, [1938].

Fonte: Arquitetura e

Urbanismo, jul.-ago.1938

Inaugurada em 1938, a

Maternidade Arnaldo

de Moraes levou o

nome do seu idealizador,

o professor de clínica

ginecológica da

Faculdade de Medicina

do Rio de Janeiro.

$O$ edifício do atual

Hospital São Lucas

guarda poucas

referências arquitetônicas

originais, representadas

pela linha modernista

expressa nas varandas e

no uso de volumes

cilíndricos.

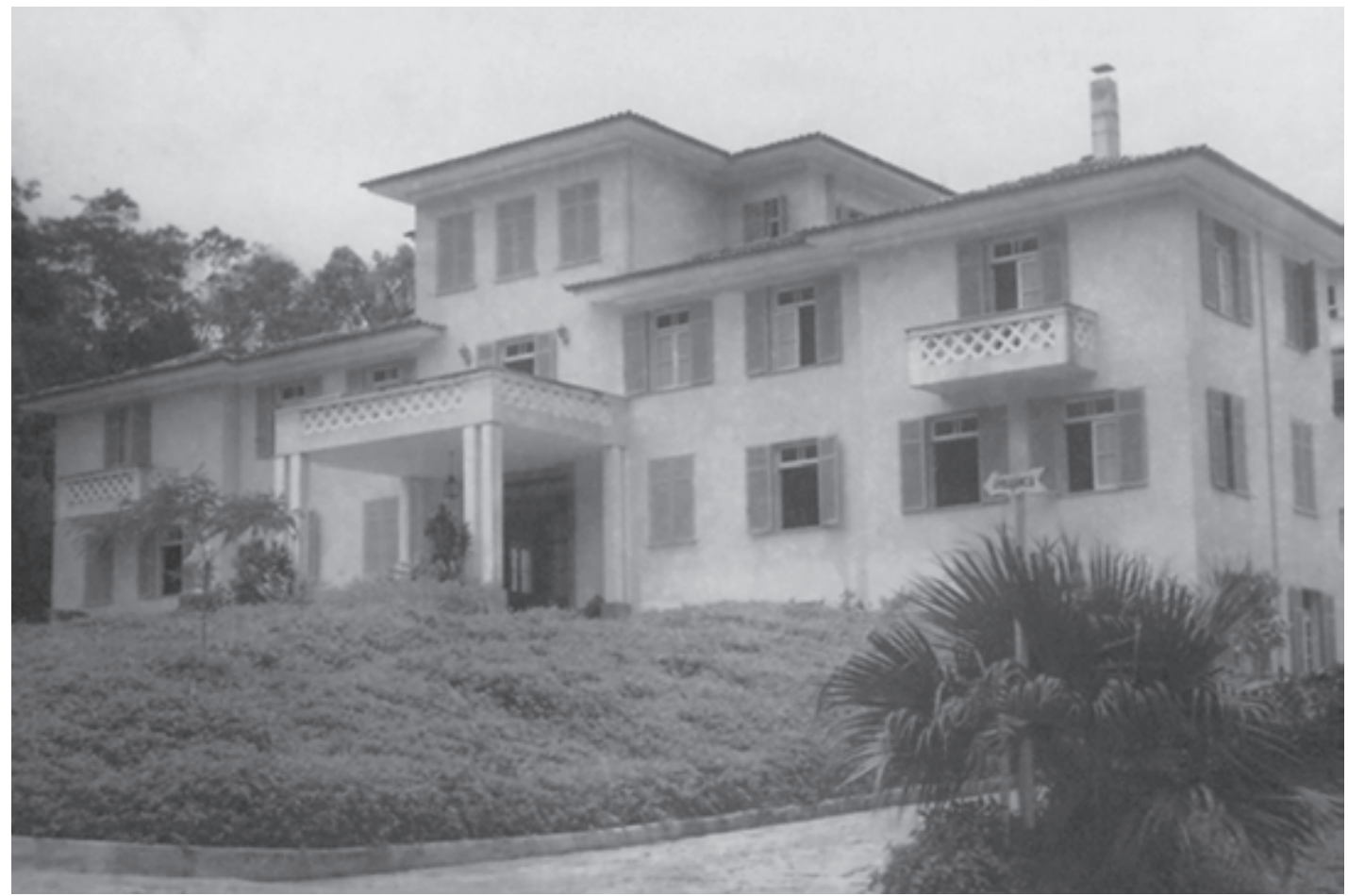

Clínica São Vicente,

1951. Acervo Clínica

São Vicente

A Clínica São Vicente

teve início com a

inauguração do

sanatório de mesmo

nome em um casarão na

esquina das ruas

Marquês de São Vicente

e Adolfo Lutz, no bairro

da Gávea. Em 1949 é

inaugurada a nova sede,

na rua João Borges, no

mesmo bairro, onde

permanece até hoje. 


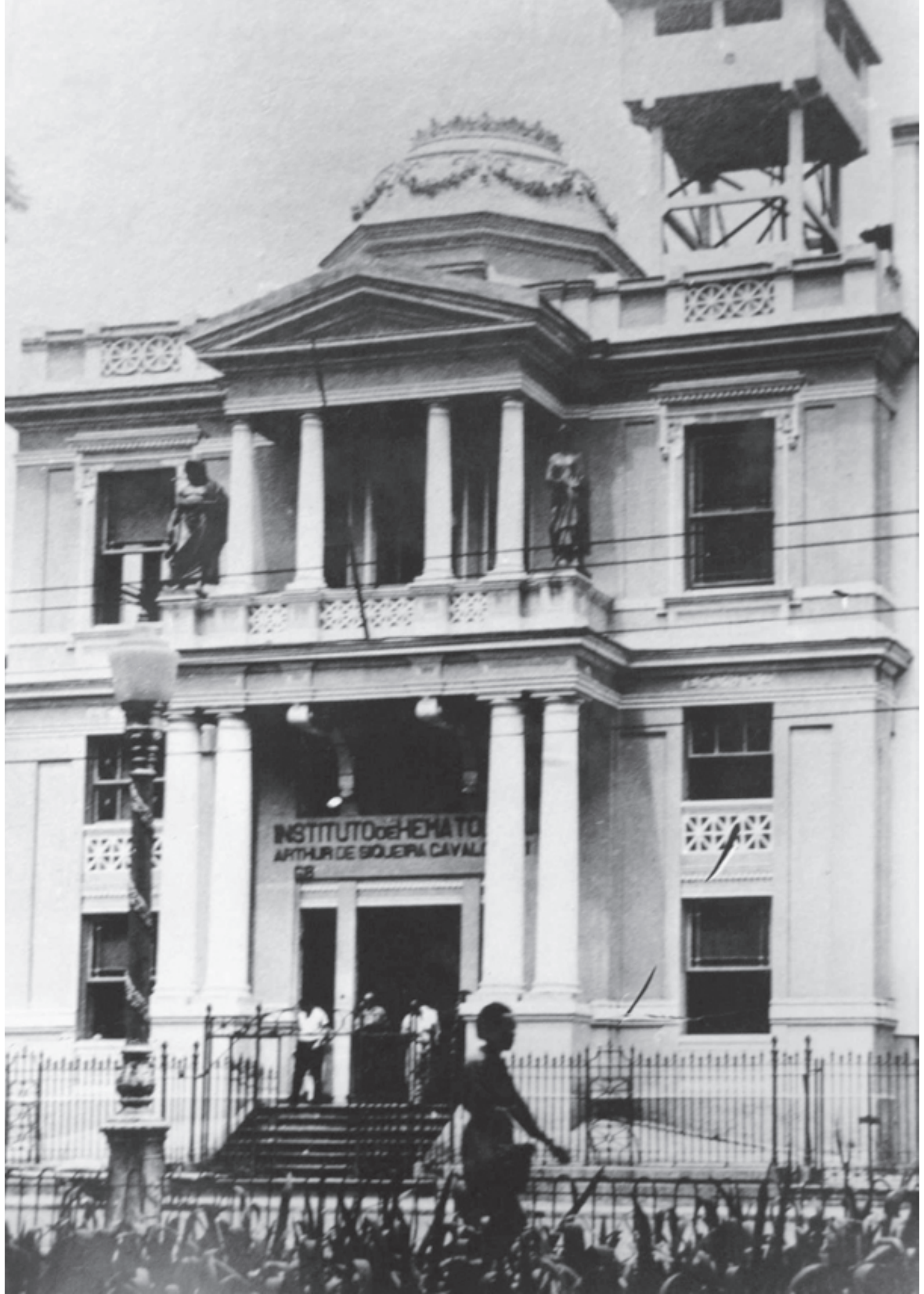

Instituto de Hematologia, [s.d.]. Acervo Hemorio

A primeira sede do instituto, inaugurada em 1944, foi em um prédio de estilo neoclássico, à rua Teixeira de Freitas, na Lapa. Na década de 1960 foram iniciadas as obras para o novo edifício, localizado na rua Frei Caneca, onde permanece até hoje. 


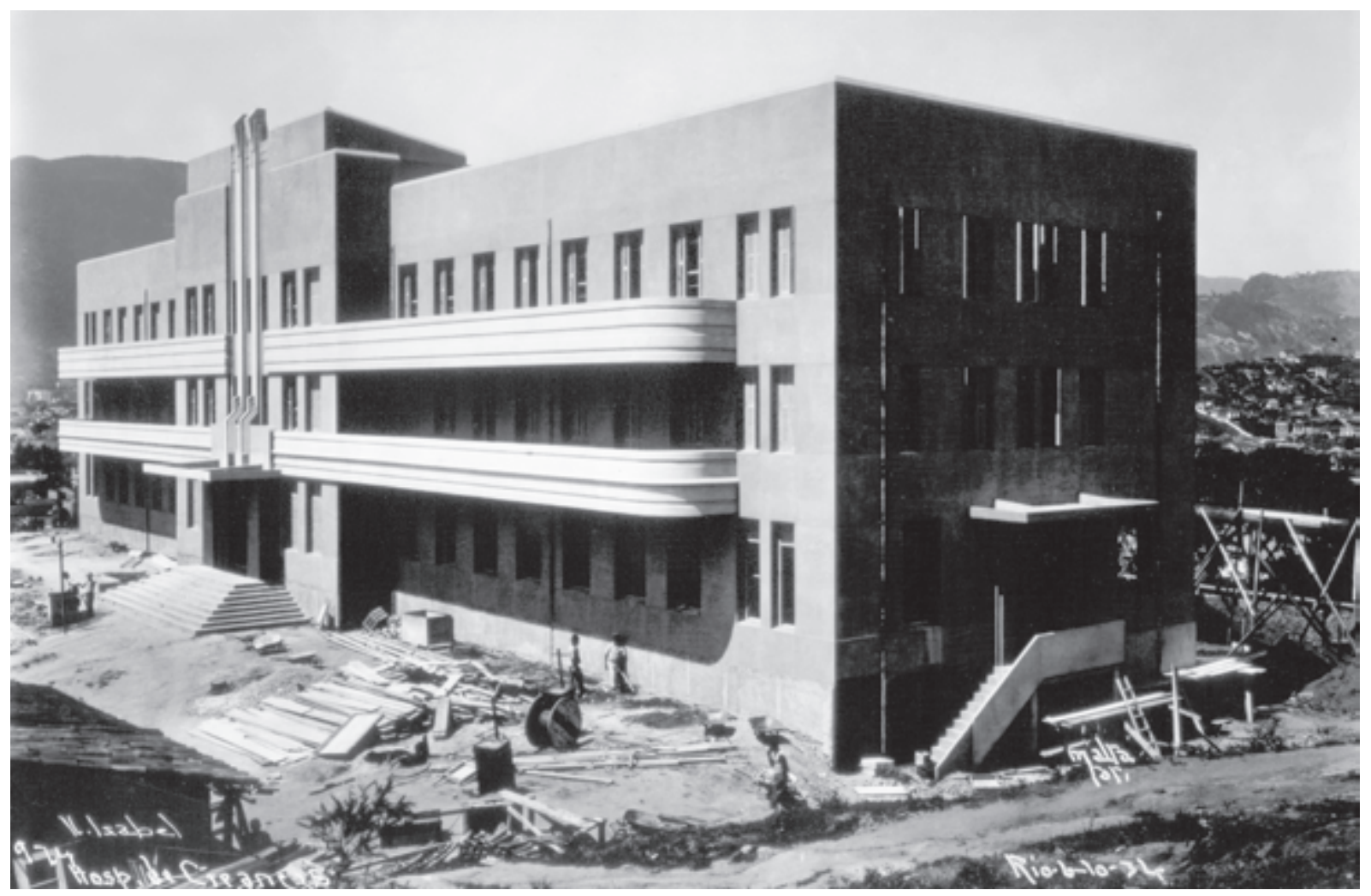

Hospital de Crianças, 6 out. 1934. Foto Augusto Malta. Acervo Arquivo Geral da Cidade do Rio de Janeiro

As obras do Hospital Jesus foram iniciadas em 1934, na gestão de Pedro Ernesto (1931-1934), e respondiam à condição imposta pela Sociedade Civil Hospital Jesus, quando da doação do terreno. Sua construção integrou o plano de abertura de hospitais policlínicos regionais e dispensários da prefeitura, apesar de destinado ao atendimento de crianças.

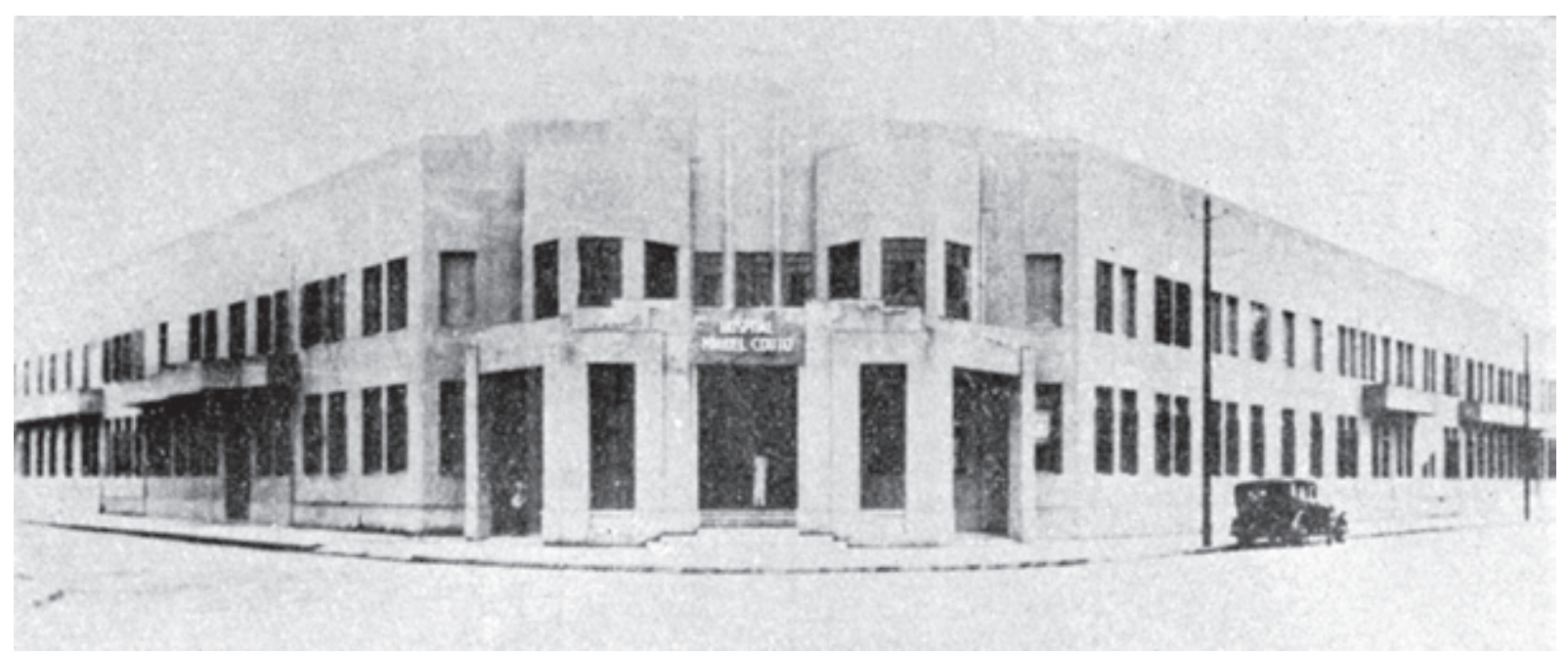

Hospital Miguel Couto, [s.d.]. Fonte: Ribeiro, 1956

Edifício em art déco inaugurado em 1935 para sede do Hospital Regional Periférico da Gávea, atual Hospital Municipal Miguel Couto. Sua construção seguiu o plano de construção de hospitais policlínicos regionais e dispensários, centrais e periféricos, desenvolvido pelo prefeito Pedro Ernesto (1931-1934). 


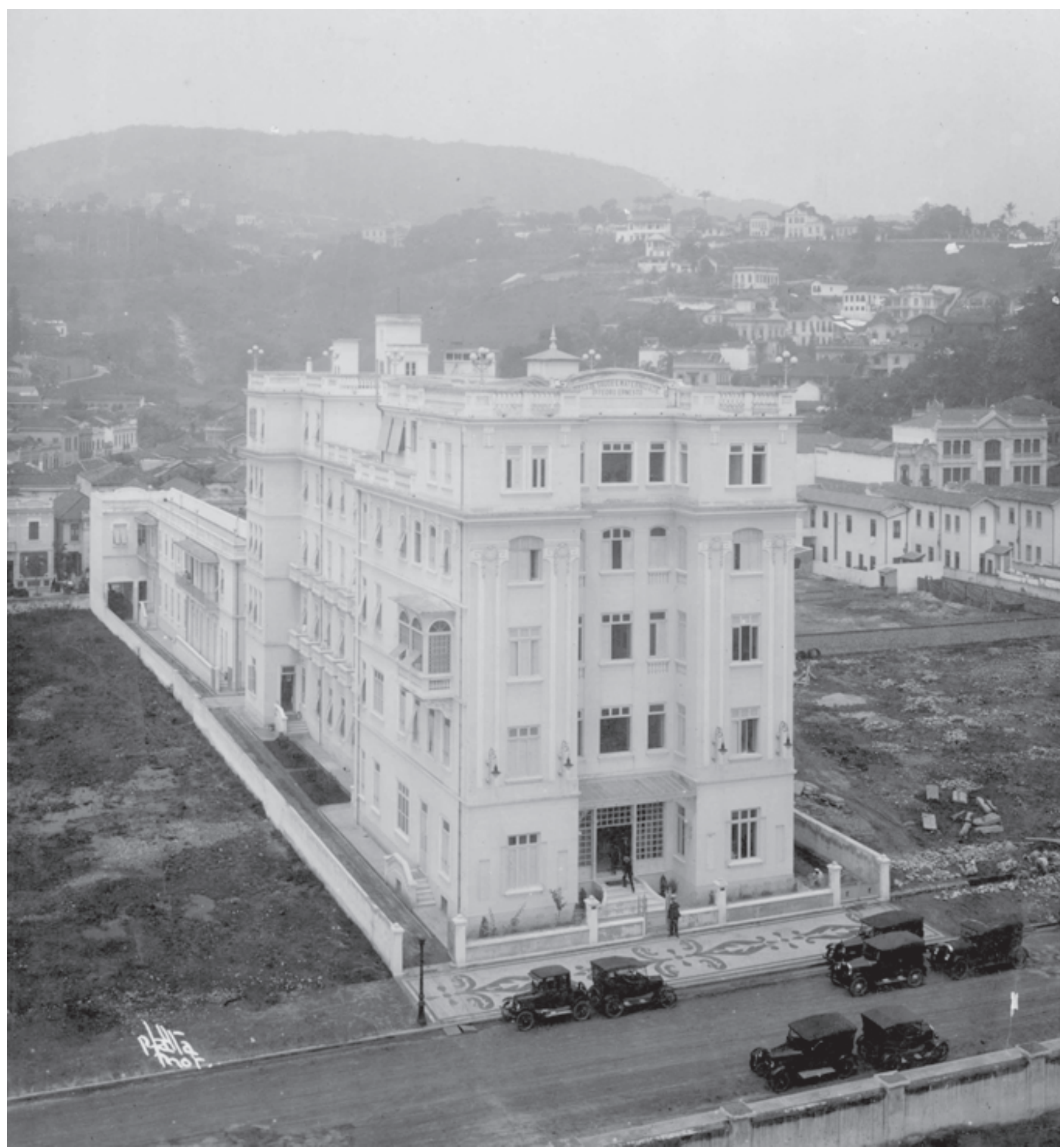

Casa de Saúde Dr. Pedro Ernesto, [s.d.]. Foto Augusto Malta. Acervo Museu da Imagem e do Som, RJ

Entre 1938 e 1939 a Sociedade de Beneficência do Servidor Municipal adquiriu o edifício da antiga Casa de Saúde Dr. Pedro Ernesto, na rua Henrique Valadares, para prestar assistência médica aos servidores municipais. O Hospital Central do Instituto de Assistência dos Servidores do Estado do Rio de Janeiro permanece no mesmo endereço, em instalações construídas na década de 1960. 


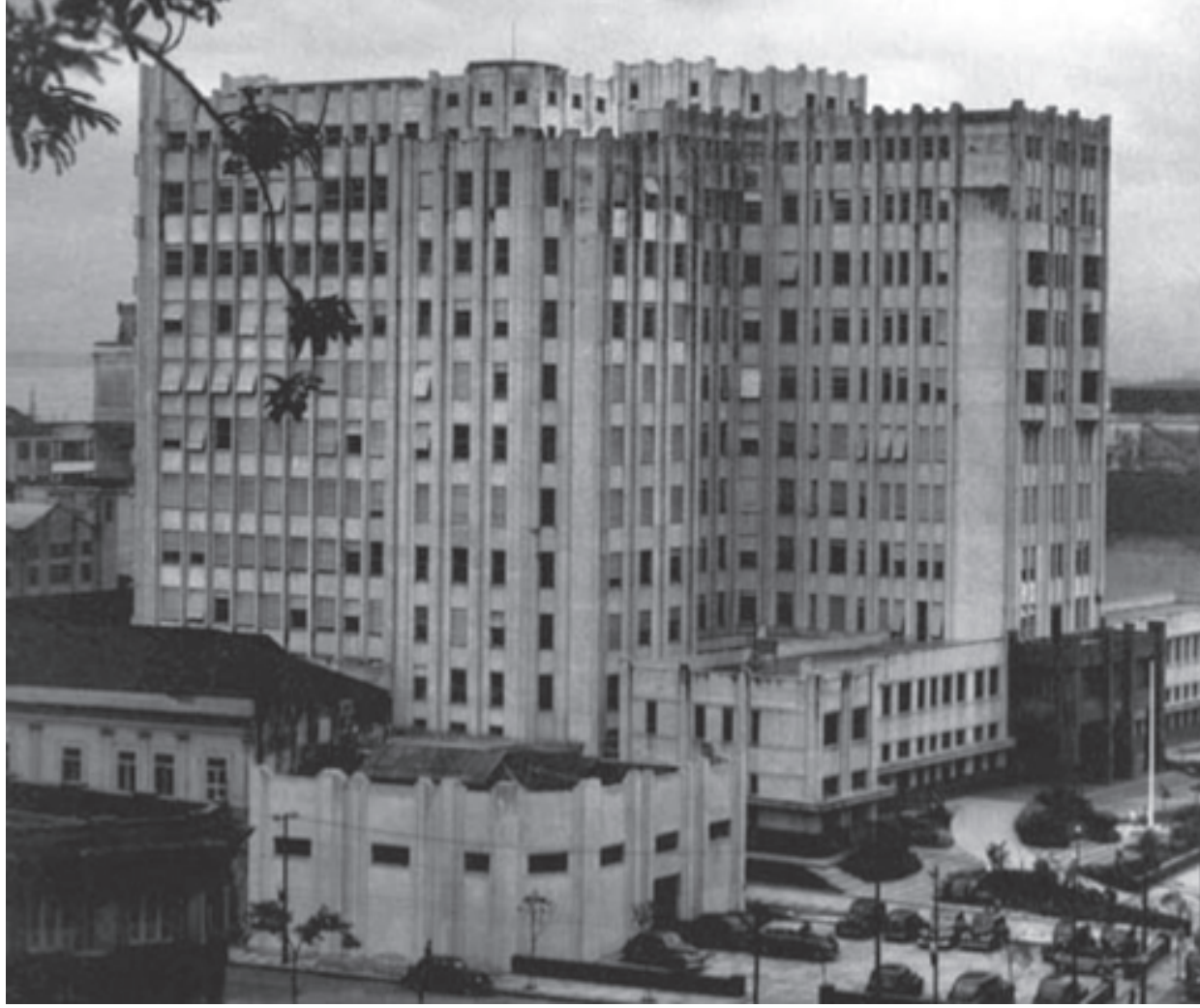

Política e Saúde

Hospital dos Servidores do Estado [195?]. Acervo Hospital dos Servidores do Estado

O projeto do Hospital do Servidor Público foi escolhido em 1935 e sintetizava a política assistencial do governo Vargas. Em 1938, com a criação do Instituto de Previdência e Assistência dos Servidores do Estado (Ipase), a construção e a gestão do hospital tornaram-se responsabilidade estadual. O projeto original sofreu transformações ao longo dos anos 1940, tendo sido inaugurado somente em 1947, já na presidência de Dutra.

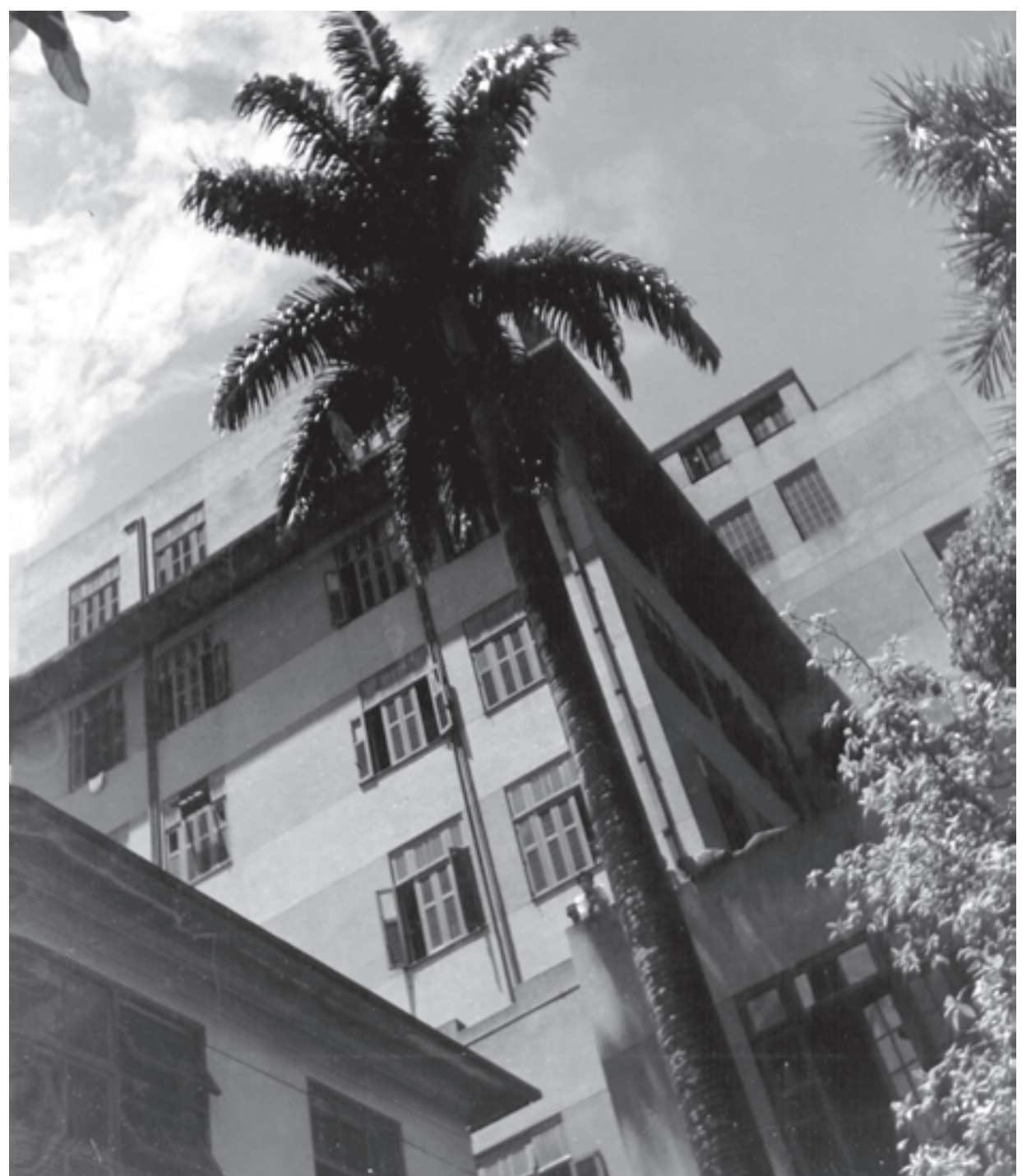

Hospital Estácio de Sá, [1930-1945]. Acervo Cpdoc/FGV

O Hospital Estácio de Sá foi construído na década de 1930 pelo Ministério da Educação e Saúde. Na década seguinte, passou a abrigar o Hospital Central da Polícia Militar do Rio de Janeiro. 


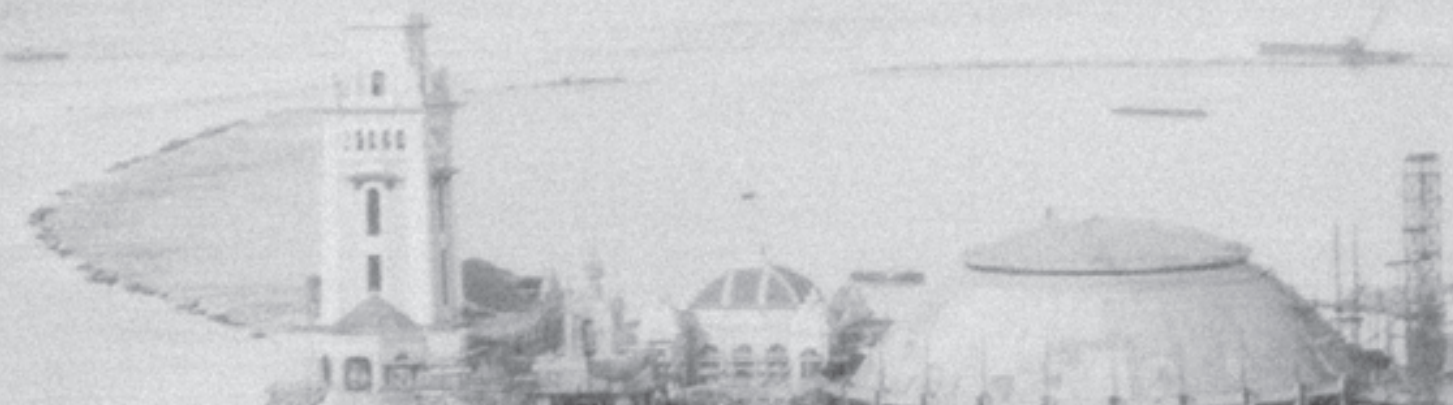

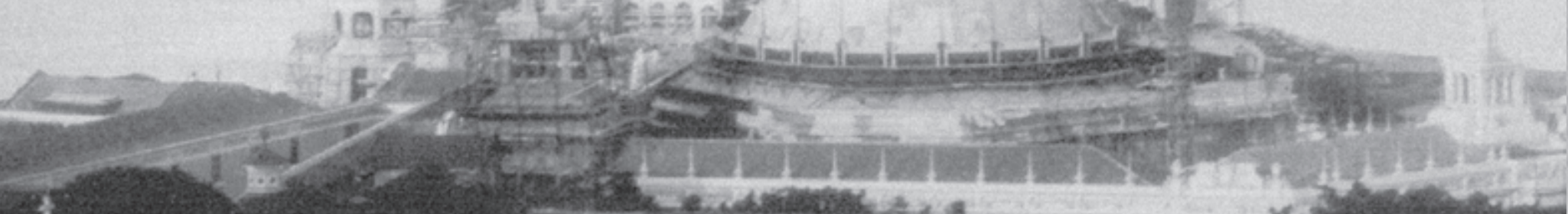

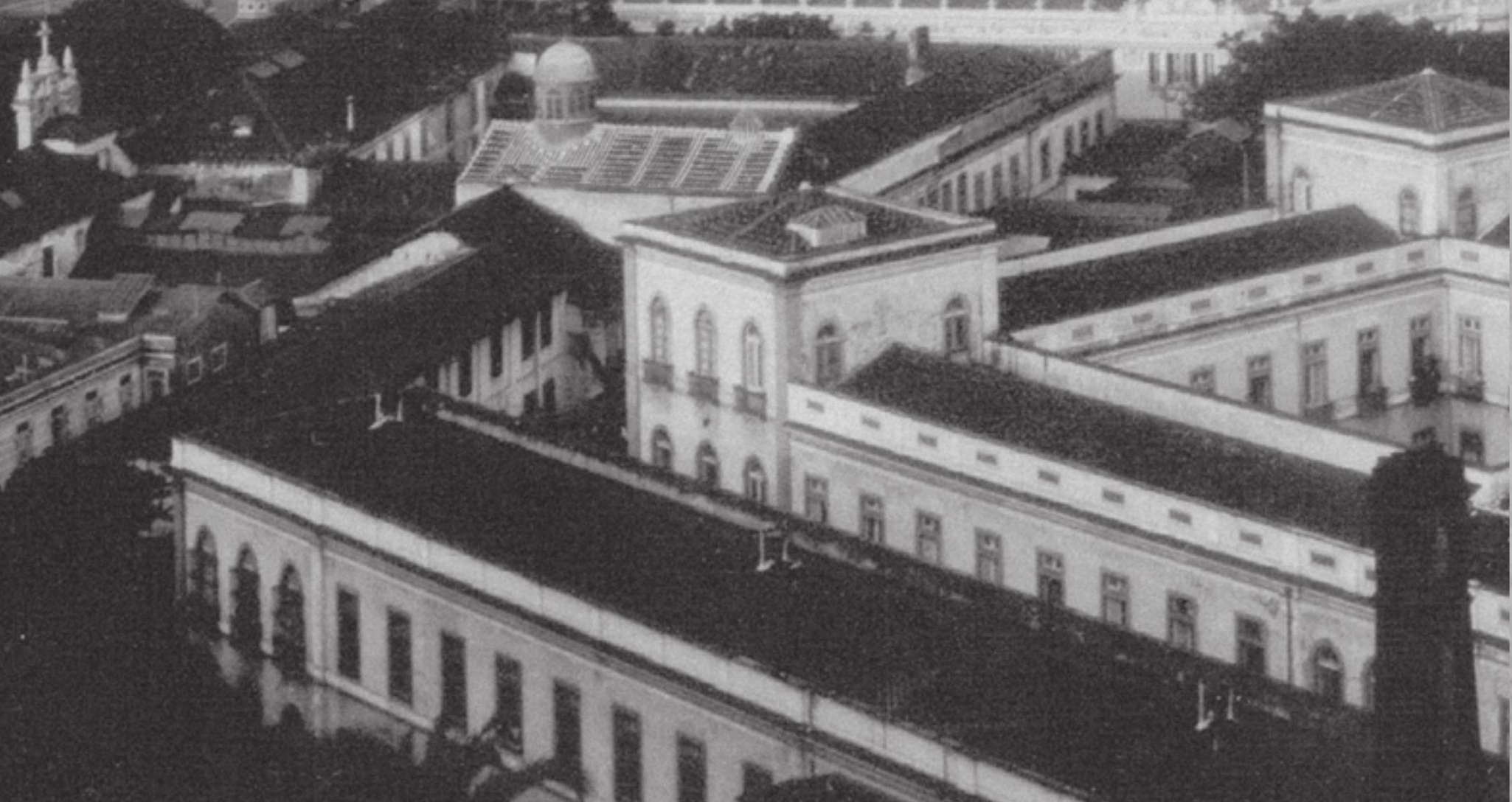


5

\section{Arquitetura e Saúde no Rio de Janeiro}

Renato da Gama-Rosa Costa 


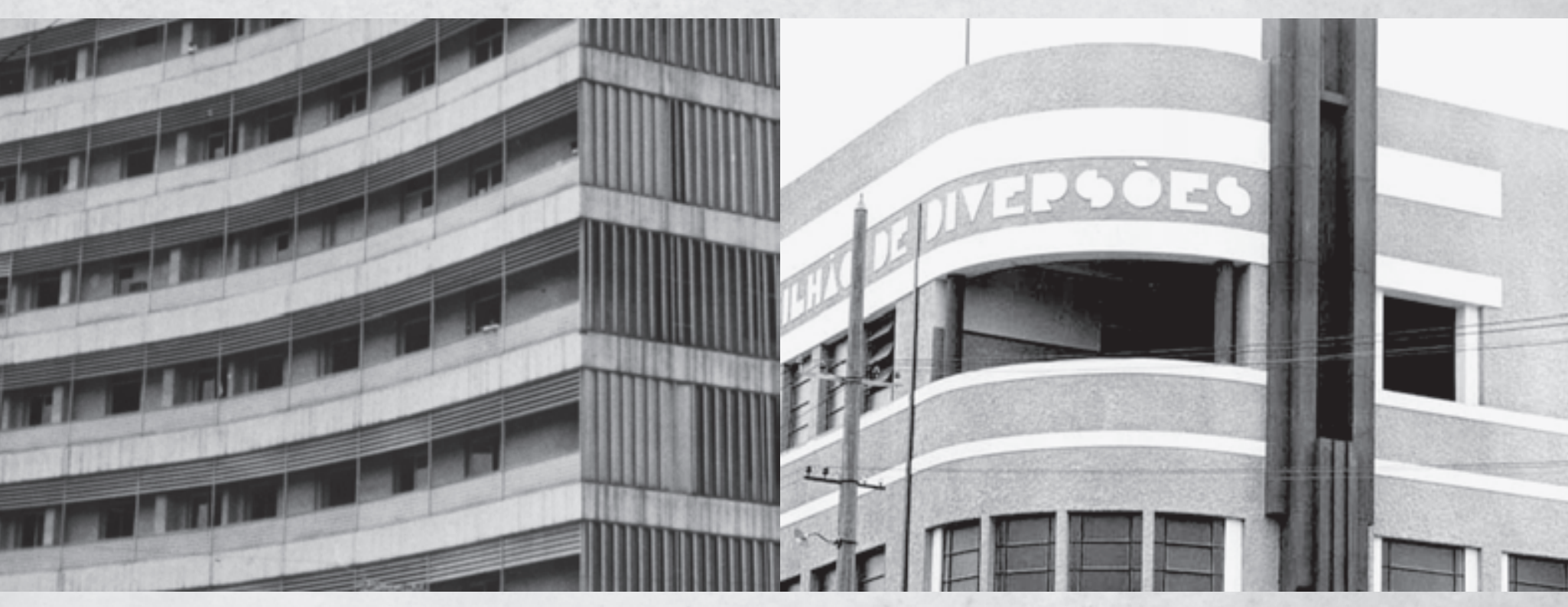


A história do hospital como instituição conta com alguns estudos clássicos desenvolvidos, mas a investigação em arquitetura hospitalar se apresenta ainda fértil. No Brasil, à exceção de estudos pioneiros de Miquelin (1992), Bittencourt (2000) e, mais recentemente, de Toledo (2006), ainda se busca quem se proponha a contar a história da arquitetura hospitalar por meio de estudos de caso. Esse é um dos objetivos deste livro e deste capítulo, em particular.

Segundo Foucault (1999), o hospital como instrumento de cura é invenção recente do final do século XVIII. Isso porque, segundo ele, o hospital não era lugar da prática médica, e o médico não fazia do hospital lócus de atuação ou de aprimoramento de seus estudos terapêuticos. O hospital era território de religiosos e suas irmandades, que visavam a amparar os pobres até sua morte. A reconstrução do HôtelDieu de Paris, entre 1772 e 1788, depois de um incêndio, iria deflagar uma tomada de consciência sobre o estado deplorável das condições higiênicas dos antigos hospitais de caridade. O tradicional uso do hospital para diferentes fins e atendimento a doentes acometidos das mais variadas formas de infecção junto com os feridos, as parturientes e as crianças, aliado a uma nova concepção de ventilação e aeração dos quartos, fez com que se criticasse a usual planta em quadrado ou em cruz dos hospitais antigos, passando-se a adotar a forma do hospital em pavilhões.

Para a reconstrução do hospital, foi convocado o cirurgião francês Jacques Tenon, que juntamente com o inglês Horward e o austríaco Hunczovsky realizavam, desde 1760, estudos comparativos buscando demonstrar estatisticamente a relação entre a taxa de mortalidade, certas práticas médicas e os espaços internos dos hospitais, tendo como inspiração o Hospital Stonehouse, de Plymouth, projetado naquele ano pelo engenheiro Roverhead (Mignot, 1983). Tal hospital seria, então, o modelo utilizado como referência para a reconstrução do hospital parisiense e de outros hospitais franceses, e foi aprovado pela Academia de Ciências daquele país, em 1786. A comissão formada por Tenon, Howard e Hunczovsky propunha, em resumo, o número de 1.200 leitos para os hospitais; maior isolamento; disposição e abertura nos quartos visando à melhor renovação do ar; organização dos pavilhões de isolamento de forma mais ordenada, dispostos em paralelo e orientados mais favoravelmente no sentido norte-sul, e, em sua maioria, compostos de um a dois pavimentos, com raras concessões a três pisos.

Entretanto, tal modelo não seria aplicado plenamente antes de 1830-1850, na construção do Hospício da Renascença, em Garches, ou mesmo antes de 1874, na construção do Hospital Lariboisière. Em certa medida, a subseqüente nacionalização das propriedades clericais na França teria contribuído para esse 
atraso (Mignot, 1983). Ao longo da segunda metade do século XIX, os hospitais comandados pelas igrejas dariam lugar a hospitais organizados por médicos, e a arquitetura dos espaços de saúde passaria a ser entendida como instrumento de cura tanto quanto "um regime alimentar, uma sangria e um gesto médico" (Foucault, 1999: 109).

Para que assim ocorresse, foi decisiva a promulgação da lei republicana francesa de 15 de julho de 1893, que instituía a assistência médica gratuita. Essa lei possibilitava que as comunas financiassem a internação de cidadãos privados de recursos e obrigava os hospitais a atendê-los. Dessa forma, os poderes públicos passaram a exigir que as admissões de doentes fossem feitas por médicos, tirando das freiras essa prerrogativa. Assim, o hospital passaria a ser gradualmente comandado por médicos, atendendo todo tipo de citadinos, fossem eles doentes venéreos ou mulheres parturientes. Essas mudanças trariam alterações profundas na arquitetura hospitalar (Faure, 1994), e esta nunca mais seria a mesma.

Pretendemos analisar aqui como tais mudanças foram traduzidas nas construções hospitalares na cidade do Rio de Janeiro, percebendo semelhanças e especificidades, e examinando as escolhas de linguagem e de forma, abrangendo desde o Hospital da Santa Casa até os hospitais monoblocos. Ou seja, da arquitetura que atendia às necessidades do culto religioso à arquitetura que seguia os preceitos higiênicos, ou da arquitetura de challet à arquitetura funcionalista.

Outro aspecto que abordaremos está relacionado à gradual atuação dos arquitetos, que assumiram a função de principais articuladores do projeto de um hospital a partir da segunda metade do século XX, com o advento da denominada arquitetura moderna. Esta utilizaria tal tipo de programa como forma de exercitar ao máximo sua capacidade de articulação de usos complexos e conhecimentos científicos em uma construção civil (Anelli, Guerra \& Nelson, 2001). Segundo o arquiteto paulista Rino Levi (1945), autor de sete projetos hospitalares realizados entre 1945 e 1960 no Brasil e na América Latina, ${ }^{1}$ a elaboração de um projeto hospitalar depende de uma equipe multidisciplinar composta por médicos e especialistas de diversas áreas, sendo o arquiteto o coordenador capaz de reunir as contribuições de cada um dos profissionais envolvidos (Anelli, Guerra \& Nelson, 2001).

Entretanto, tal metodologia de construção de hospitais teria outros resultados. As décadas de $1960 \mathrm{e}$ 1970 assistiriam a uma predominância da técnica sobre a arquitetura no uso da tipologia do monobloco, construção que reunia em uma só edificação os setores destinados ao tratamento de doenças diferentes, antes separados por pavilhões. Em busca de uma funcionalidade extrema, o que se percebe é que, a partir de então, a tecnologia da construção seria cada vez mais predominante, em detrimento de uma maior capacidade criativa dos arquitetos. Não por acaso, resolvemos delimitar nossa pesquisa até o ano de 1958, anterior a essas duas décadas.

A evolução da arquitetura para a saúde não apresenta uma linearidade, que possa dar a entender que uma solução posterior seria melhor que a anterior; nessa trajetória percebem-se a co-existência, em determinadas épocas, de dois ou mais modelos. Na verdade, o que se percebe é que essa disciplina procurou responder da melhor maneira possível aos desafios impostos na sua relação interdependente, ao longo de séculos, com a medicina, que também, por sua vez, não seguiu de forma linear e progressiva. 


\section{A Assistência aos Pobres e o Hospital Religioso}

Roberto Machado (Machado et al., 1978) e Russel-Wood (1981) foram dos poucos estudiosos a realizar investigação mais profunda sobre os hospitais das casas da Misericórdia, trazendo o tema para a especificidade brasileira. Segundo Russel-Wood, em toda a América espanhola a responsabilidade pelos serviços hospitalares não cabia à municipalidade. A Igreja e as ordens religiosas assumiam tal tarefa, que no Brasil caberia à Irmandade da Misericórdia, a mais ativa nesse aspecto, mesmo que de forma limitada.

O primeiro Hospital da Santa Casa do Rio de Janeiro, de 1582, era parte de um conjunto de obras de caridade oferecidas pelas misericórdias, divididas em sete espirituais e sete corporais. Ao hospital cabia, certamente, curar os enfermos; cobrir os nus; dar de comer aos famintos; dar de beber a quem tem sede; dar pousada aos peregrinos e pobres; enterrar os mortos. Para Machado, "o serviço hospitalar da Santa Casa do Rio de Janeiro limitava-se, no começo do século XVIII, a apenas dois médicos, um cirurgião e um enfermeiro auxiliado por um ajudante e mais dois escravos, para uma população de mais ou menos duzentos e cinqüenta doentes" (Machado et al., 1978: 59).

A instalação da Corte portuguesa, em 1808, no Rio de Janeiro traria mudanças significativas nessa relação. Em 1813, determinou-se que a Academia Médico-Cirúrgica tivesse seu curso ministrado no Hospital da Santa Casa. Tal situação se manteria mesmo depois da criação da Faculdade de Medicina do Rio de Janeiro, em 1832. A convivência com a faculdade foi fundamental para que o estabelecimento da Misericórdia fosse palco das transformações no exercício das artes de curar e não apenas de amparar a morte. A presença da medicina acadêmica naquele ambiente e o aumento do número de atendidos tornaram evidentes os problemas da estrutura física do prédio, considerado inapropriado para o tratamento dos enfermos, segundo as concepções médicas da época. Além do mais, as discussões na Assembléia Constituinte de 1823, questionando os espaços da Santa Casa, considerados insalubres, levaram à elaboração de um relatório que recomendava a construção de um novo hospital para a Santa Casa; este foi edificado em 1854, já dentro dos preceitos da higiene, como veremos adiante. Tal relatório indicava, ainda, outros melhoramentos na área da saúde, como a construção de edifícios especiais para os alienados, para os expostos e para as órfãs.

No Hospital dos Lázaros, a maior atenção à arquitetura revela o grau da cumplicidade estabelecida em certo momento entre arquitetura, medicina e religião. O hospital foi construído entre 1748 e 1752 , constituindo-se de uma planta quadrangular, com pátios internos e capela central, disposição que se manteve mesmo depois da adaptação para receber os leprosos, em 1766. As celas dos jesuítas, usadas como quartos para os pacientes, assim permaneceram até 1892, quando foram finalmente destruídas, transformando-se o espaço em salões-enfermarias (Pôrto \& Oliveira, 1996). Era rara a presença de médico, sendo os pacientes atendidos por cirurgião e auxiliados por enfermeiros e pelos religiosos.

Procurando acompanhar os avanços no tratamento e conforto dos pacientes e atender aos preceitos da higiene, o lazareto passou por diversas reformas, principalmente no último quartel do século XIX. As reformas continuaram no século seguinte, entre 1917 e 1920, e permitiram que suas instalações se tornassem modelo de higiene, incentivando outras melhorias, precursoras do que seria exigido para as construções hospitalares nos anos posteriores. Em termos formais, o Hospital dos Lázaros procurou manter as linhas mais próximas às da arquitetura religiosa, adotando o neogótico como elemento principal de linguagem 
e estilo. Ao longo das reformas, as construções do lazareto incorporaram elementos estéticos neoclássicos, ecléticos e art nouveau, sem entretanto deixar de lado a referência religiosa.

Os projetos arquitetônicos de espaços de isolamento para alienados, como o asilo de mendicidade construído entre 1884 e 1889, desenvolveram-se em composições que seguiam os princípios de instituições prisionais da Europa, como o panóptico de Bentham. O partido arquitetônico ${ }^{2}$ do asilo, atual Hospital São Francisco, adotou a configuração volumétrica formada por um corpo central e cinco bastões em justaposição, em dois pavimentos. Essa solução radial, que induzia ao confinamento e ao controle, também foi objeto de projetos para hospitais que encontram no Brasil pouquíssimos exemplares, sendo um dos mais destacados o do Sanatório de Belém, localizado em área afastada da cidade de Porto Alegre. Na reforma que transformou o antigo asilo em hospital-geral, a estrutura original de alas foi aproveitada como hospital pavilhonar - adaptação para salões-enfermarias, criação de consultório isolado, racionalização do sistema de higiene e de circulação. ${ }^{3}$ Fazia parte do projeto original uma capela localizada no corpo central da edificação, evidenciando o quanto, tradicionalmente, se devia à religião o tratamento de seus doentes.

\section{Da Arquitetura Higienista à Arquitetura dos Pavilhões}

A higiene seria responsável pela transformação na forma arquitetônica dos primeiros hospitais, principalmente depois das epidemias que assolaram o Rio de Janeiro na segunda metade do século XIX. Tais preceitos foram traduzidos em investimentos na separação de alas para enfermos, independentes porém interligadas por corredores muitas vezes subterrâneos; no isolamento das grandes concentrações urbanas; na atenção aos benefícios da aeração e ao combate à umidade.

O novo hospital para a Santa Casa de Misericórdia obedeceu a tais princípios, erguendo, entre 1840 e 1852, uma grande construção com feições neoclássicas, distribuída em dez alas e seis pátios internos, de composição simétrica e quadrangular, projetada pelo arquiteto-engenheiro José Domingos Monteiro, ex-integrante do Imperial Corpo de Engenheiros e arquiteto da Câmara. Monteiro foi designado como arquiteto das obras da Santa Casa pelo provedor da instituição, José Clemente Pereira, que fez um levantamento dos defeitos das antigas instalações, então em desacordo com as regras de higiene do Oitocentos: arquitetura irregular; enfermarias situadas abaixo do solo, úmidas e destituídas da necessária circulação de ar; enfermarias muito pequenas para as mulheres; os tísicos, assim como os bexiguentos, não separados dos demais doentes; acomodações para os alienados que pareciam cárceres. Tais condições eram agravadas por infiltrações, goteiras e ameaças de desabamento em algumas partes do edifício.

Um relato de viagem produzido à época (1868-1870) pela expedição de Bourdel-Roncière, médico francês responsável pela saúde a bordo de uma das embarcações francesas que respondia aos interesses da geografia médica e da colonização européia (Morais, 2007), atestava a situação desfavorável da Santa Casa do ponto de vista da higiene. Relatos como esse legitimavam a autoridade dos médicos europeus e seu diagnóstico sobre um país, essencial para o andamento da empresa colonialista:

Suas opiniões sobre as condições gerais dos hospitais, as doenças mais comuns, o número de funcionários disponíveis - médicos, farmacêuticos e enfermeiros -, as despesas hospitalares, a arquitetura do prédio 
e os tratamentos correntemente utilizados pelas comunidades médicas locais serviam como verdadeiros guias às autoridades governamentais e, conseqüentemente, a outros médicos exploradores. (Morais, 2007: 47 $)^{4}$

Segundo o relato, a arquitetura do prédio da Santa Casa foi considerada à altura dos melhores estabelecimentos europeus, principalmente os franceses, tidos como modelos. Foram elogiados, igualmente, o bom espaço entre as camas, o tamanho dos corredores e a existência de jardins, elementos essenciais para a salubridade de um hospital. Apesar dos elogios também quanto aos materiais empregados em sua construção - granitos e madeiras nobres -, revelando o esforço empreendido por Monteiro e Pereira, a higiene hospitalar deixava muito a desejar. Sua localização aos pés do morro do Castelo era tida como inapropriada do ponto de vista higiênico, "em virtude da quase perpendicularidade dos morros em relação aos ventos, o que representava um obstáculo à ventilação" (Morais, 2007: 49). Sabemos o quanto a localização de um hospital era importante para a manutenção de suas condições salubres.

De fato, nesse mesmo período deu-se a construção do Hospício Pedro II. Seguindo os preceitos de proporcionar "calma, tranqüilidade e espaço" aos alienados (Tundis \& Costa, 1990: 38), a edificação do hospício foi implantada na praia Vermelha, um sítio afastado da cidade e muito arejado. O acesso difícil tornava garantido o isolamento dos pacientes, bem como a proteção contra eventuais fugas. O partido adotado para o hospício de isolamento foi o de forma pavilhonar, com seis pátios internos. Sua configuração obedeceu a um programa comum aos estabelecimentos hospitalares de Paris, confirmando o Hôtel-Dieu como grande modelo a servir de inspiração em todo o mundo; seu programa constituía-se de enfermarias, farmácia, salões e uma capela.

Até o final do século XIX seriam construídos o Hospital da Beneficência Portuguesa, o Hospital São Sebastião e o Hospital Evangélico. O que se percebe de comum às arquiteturas desses hospitais é a tentativa de responder com qualidade construtiva às questões impostas pela higiene: o uso de pavilhões de isolamento para o acolhimento das doenças infectocontagiosas ou separação por sexo; o uso de pátios internos e grandes janelas para facilitar a aeração e a ventilação dos quartos. E no caso do São Sebastião, adotou-se ainda o isolamento da malha urbana.

Quanto à linguagem arquitetônica, vê-se o uso do neoclássico, conjugado com o estilo challet na decoração e no uso dos materiais construtivos. De forma geral, o neoclássico aparece nos edifícios principais do conjunto, com destaque para as fachadas de acesso, tendo a linguagem do challet se restringido ao interior das edificações ou aos pavilhões de isolamento. No caso da Beneficência Portuguesa, seu edifício principal, construído entre 1848 e 1853, apresenta o único exemplar de frontão arqueado do classicismo carioca, elemento que seria repetido no pavilhão construído quarenta anos depois.

As opções pela linguagem neoclássica e em challet permaneceriam ainda em alguns hospitais na primeira década do século XX, embora já inseridos na releitura proporcionada pelo movimento do ecletismo arquitetônico, como no Hospital da Cruz Vermelha, no Hospital de Manguinhos e naquele construído para o Instituto Nacional de Educação de Surdos. Foi uma época de novas descobertas da medicina, como a da transmissão de doenças por germes, e o trabalho do engenheiro francês Casimir Tollet, de 1892, apresentou uma solução definitiva para a renovação do ar nas enfermarias que consistia na construção de ambientes com paredes de altura elevada, com seção em arco e abertura no teto, junto aos telhados, de modo a permitir a saída do ar viciado pela parte de cima do ambiente. Tal sistema 
permitiria um novo tipo de inserção do hospital no meio urbano, sem as exigências de espaços ao redor da edificação para a ventilação e renovação do ar ao nível das janelas.

O projeto do Hospital de Manguinhos, de Luiz Moraes Jr., construído durante os últimos anos de vida de Oswaldo Cruz, entre 1912 e 1917, ainda seguia as recomendações de um hospital higiênico: amplas varandas, pé-direito alto e sistema de refrigeração, que facilitavam a aeração e proporcionavam maior conforto nos quartos. O programa norteador, no entanto, foi a bacteriologia, segundo a qual cada doença deveria ser combatida em separado, ou seja, em cada pavilhão. Seu projeto original previa a construção de mais cinco outros pavilhões. Tal empreendimento não logrou êxito, dada a morte prematura do cientista, e o único pavilhão construído destinou-se ao tratamento de doenças tropicais, como a doença de Chagas, a febre amarela, a leishmaniose visceral e tegumentar, a doença de Lutz e o pênfigo foliáceo.

As descobertas feitas especialmente por Pasteur e seus seguidores e a progressiva individualização das doenças infectocontagiosas, associando um micróbio a uma enfermidade e seus sintomas, levariam a uma revisão da terapia do isolamento. Para as doenças que ainda exigiam o afastamento do paciente do restante da sociedade, o hospital de isolamento ainda era o modelo a se seguir. Em termos de arquitetura, os sanatórios experimentariam uma série de referências e formas construtivas, tornando-se laboratórios de pesquisa estética e construtiva.

Para atender aos demais tratamentos que não necessitavam de isolamento e para outras enfermidades que surgiriam com a modernidade do século XX que já se anunciava, como os ferimentos de guerra e os decorrentes de acidentes do trabalho e do trânsito, seriam construídos os hospitais gerais e de prontosocorro. Estes passaram a ocupar terrenos urbanos mais centrais.

Em certa medida, isso foi sentido na criação dos hospitais da Cruz Vermelha, que visavam a atender aos feridos dos inúmeros episódios de conflitos no século XIX, estimulando o trabalho, desde 1863, do Comitê Internacional para Ajuda aos Militares Feridos. Em 5 de dezembro de 1908, foi fundada a Cruz Vermelha Brasileira, como órgão de assistência pública e privada no Rio de Janeiro, com o intuito de estabelecer no país um corpo de auxílio hospitalar semelhante aos criados em outras cidades do mundo, localizados em pleno centro urbano. De certa forma, a inauguração do Hospital de Pronto-Socorro (atual Hospital Municipal Souza Aguiar), em 1925, visava a atender aos acidentados, vindo a se localizar em plena praça da República.

\section{Os Anos 20 e a Arquitetura de Transição, entre o Modelo Higienista, o Pavilhonar e o Monobloco}

A década de 1920, no Rio de Janeiro, foi um período de busca de novos tratamentos e terapias, situados entre a tradição das Misericórdias e a modernidade trazida pelos estudos da bacteriologia, que se impunha cada vez mais. A produção para a saúde nesses anos esteve concentrada nos projetos hospitalares do engenheiro-geógrafo Adelstano Porto d'Ave, a serviço da reforma sanitária empreendida por Carlos Chagas, à frente do Departamento Nacional de Saúde Pública, e das ações filantrópicas da família Guinle. À semelhança do que ocorrera com o arquiteto Luiz Moraes, que acompanhara Oswaldo Cruz em sua gestão na então Diretoria-Geral de Saúde Pública e no Instituto Oswaldo Cruz, realizando, a pedido do cientista, os projetos de construções entre os quais se incluía um bom número de edificações 
hospitalares, o grau de parentesco com os Guinle permitiu que Porto d'Ave desenvolvesse os projetos de três hospitais planejados por Carlos Chagas. ${ }^{5}$

Foram projetados, então, o Hospital Gaffrée \& Guinle, o Hospital do Câncer e o Hospital das Clínicas da Faculdade de Medicina, numa época em que a Santa Casa dava sinais de esgotamento na assistência pública. E era necessário construir, com a participação da iniciativa privada, uma rede hospitalar para combater casos de epidemia ou doenças não tratadas na Santa Casa, principalmente a lepra e as doenças venéreas. Daqueles hospitais, apenas o primeiro foi construído em sua integridade.

O projeto para o Hospital Gaffrée \& Guinle foi desenvolvido por Porto d'Ave e seu sócio Haering, entre 1923 e 1929, data de sua inauguração. O hospital foi concebido para internar 320 pessoas e contava com um prédio principal de quatro pavimentos munido de elevador - o quarto andar era destinado ao solarium -, onde se localizavam diversos serviços e um ambulatório. Sua tipologia seguiu a do hospital higienista, com as enfermarias destacadas do corpo principal da edificação central, segundo a tradicional preocupação com a correta ventilação e insolação para o tratamento dos pacientes. Em certa medida, sua arquitetura se preparava para a tipologia que surgia nos Estados Unidos e que se tornaria hegemônica nas décadas seguintes: a do monobloco.

A estética arquitetônica acompanhava a separação das duas tipologias: a linguagem do neocolonial, predominante no Brasil da época, domina o corpo da fachada principal e os prédios menores, como a capela. Já o bloco de quatro pavimentos apresenta uma estética mais próxima de um classicismo alemão.

Nos demais projetos, Porto d'Ave se esforçaria para corresponder ao que ele entendia à época por um hospital moderno, que em sua concepção se traduzia em um hospital de função eminentemente socioeducativa, localizado em um ponto de fácil acesso e (sic) alegre e atraente (Sanglard \& Costa, 2004). Além do mais, o engenheiro tinha como referência não mais os modelos franceses, e sim os alemães e norte-americanos. Não é de se estranhar o desafio imposto a Porto d'Ave: até a década de 1930, prevalecia a tipologia do hospital pavilhonar, que seria suplantada logo depois pelo tipo monobloco. Os projetos hospitalares dos anos 1920 estavam, portanto, enfrentando um período de transição, quando mesmo os médicos hesitavam entre um modelo e outro. A própria França se mostrava dividida entre adotar um ou outro: o modelo norte-americano, constituído por instalações pavilhonares à semelhança de tendas (as tent-houses) em madeira, herdeiras das instalações tipo barraca dos hospitais-campanha, a serem queimadas todos os anos, e o modelo alemão, formado por uma única construção longilínea, equipada por balcões e galerias de cura, mais duradouro. De comum às duas tipologias, o fato de as construções estarem implantadas em um imenso parque, quase cidades-jardins.

Porto d'Ave desenvolveu dois projetos para o Hospital do Câncer (hoje Hospital Municipal Barata Ribeiro), um para o terreno próximo ao Cais do Porto e outro para o atual terreno, na Mangueira. Em ambos prevalecia a idéia de se fazer pavilhões de um a quatro pavimentos, mantendo-se a linguagem arquitetônica de linhas clássicas. Na mudança de terreno, as instalações ganharam dimensões ainda mais generosas, acentuando a planta em U, tão própria das construções hospitalares da época. Infelizmente, pouco restou desse projeto.

Pior destino teria o Hospital das Clínicas, vítima das discussões sobre a modernidade hospitalar de finais da década de 1920. Novamente Porto d'Ave faria uma série de projetos, tentando satisfazer às exigências impostas, principalmente, por João Marinho, então diretor da Assistência Hospitalar. O primeiro 
plano apresentado em 1926 previa que o hospital seria construído segundo a escola alemã, adotando prédios divididos em clínicas, alojadas em pavilhões interligados por passagens subterrâneas, mas cuja organização interna seguiria a lógica das enfermarias norte-americanas. O projeto sofreu duras críticas por parte dos adeptos do sistema monobloco, que preferiam reunir os pavilhões em uma única construção. Outras críticas foram feitas em relação a sua localização, pois uns o queriam afastado da aglomeração urbana, certamente presos às questões higiênicas mais tradicionais, que exigiam grandes terrenos em volta para a ventilação do ar, ignorando a contribuição de Tollet, e outros preferiam um terreno no Mangue, próximo ao Hospital São Francisco e à Escola de Enfermagem Anna Nery. Outro ponto de discussão foi se a maternidade deveria ficar dentro ou fora do corpo principal da construção.

Mas a polêmica principal do debate girava em torno da idéia de que, para ser um hospital verdadeiramente moderno, ele deveria abraçar sem restrições o modelo do bloco único. Marinho tinha como referência o Hospital das Clínicas de São Paulo e o Hospital de Rochester, de Nova York. Porto d'Ave, por sua vez, procuraria adotar a arquitetura do Hospital Johns Hopkins, de Baltimore, copiada em sua disposição de planta assimétrica e em sua verticalidade. Em meio às desavenças, a construção iniciou-se em 1929, mas como a obra foi definitivamente embargada em 1934, virou um grande esqueleto de armação de ferro posteriormente ocupado por moradores de baixa renda, transformando-se em favela.

Outra tendência se consagraria a partir da década de 1920: a eminente separação entre as categorias de hospital geral e hospital de isolamento. Essa separação não diria respeito apenas às terapias, mas estaria refletida igualmente na sua inserção urbana e na sua forma e linguagem arquitetônicas. O tratamento dos tuberculosos na segunda metade do século XIX exigiu hospitais de isolamento e garantiu seu uso ainda durante a prevalência do monobloco, no século seguinte, especialmente para pacientes tido como perigosos, como os portadores de hanseníase (Bittencourt, 2000).

José Messias do Carmo, em obra de 1948, discorreu sobre a definição, a característica e a organização de um hospital de isolamento. Dois hospitais serviam de modelo à época: o Hospital Pasteur de Paris e o Providence City Hospital, de Rhode Island, EUA. Para o autor, ainda se fazia necessária a construção de um grande hospital de isolamento para o Distrito Federal, pois apenas o São Sebastião, o São Francisco de Assis e o Hospital Evandro Chagas (antigo Hospital de Manguinhos) cumpriam tal função. O número de leitos deveria chegar a mil ou 1.500, mas divididos em construções com quinhentos leitos cada, situadas em área urbana e suburbana. Acima desse número, segundo Carmo, o rendimento do hospital começava a cair e sua administração se tornava árdua.

O autor, entretanto, não considerava em suas estatísticas as colônias rurais criadas no Rio de Janeiro para o tratamento de doentes que necessitavam de isolamento, implantadas na região de Jacarepaguá nas décadas de 1910 e 1920, como era o caso das colônias Juliano Moreira, para alienados, e de Curupaity, para leprosos. Vale aqui ressaltar a importância da região de Jacarepaguá na construção desses hospitais de isolamento, à semelhança do que ocorreu com os bairros do Caju e de São Cristóvão nos séculos anteriores. Em torno do morro Dois Irmãos, pertencente ao maciço da Pedra Branca e em meio à reserva primitiva da Mata Atlântica, seriam inaugurados ainda o Sanatório de Santa Maria, na década de 1940, e o Sanatório de Curicica, na década seguinte.

A terapia para tratamento dessas doenças procurava minimizar a sensação de perda da cidadania advinda da retirada dos pacientes do convívio em sociedade; tal preocupação se traduzia na criação de 
pequenos ambientes urbanos, com a reprodução de elementos típicos de uma cidade, como a praça, as residências familiares e o espaço de lazer e entretenimento, expresso na instalação de cine-teatros, clubes, salões de dança, entre outros. A arquitetura procurava acompanhar essa tentativa de se criar um ambiente familiar, adotando uma linguagem mais singela e tradicional, próxima de nossas raízes coloniais portuguesas, com construções de um pavimento e porão elevado, fazendo uso de telhados em duas águas, paredes com revestimento em baixo-relevo, geralmente na cor branca, e esquadrias de madeira. O arroubo estético ficava para as construções que abrigavam os espaços de cura, administrativos e de lazer: a linguagem utilizada foi a do art déco, cujo exemplar mais significativo está presente no cine-teatro de Curupaity.

A partir da década de 1930, caberia aos norte-americanos a primazia na adoção do sistema monobloco, aqui mencionado, ensaiado pelos alemães nas suas construções longilíneas e interligadas como uma construção única. Tal sistema, que se expressava na separação das doenças pelos diversos pavimentos de um mesmo edifício e na racionalização de circulação e trânsito de pessoal, de doentes e de material infectado, seria plenamente adotado aqui no Brasil, ao menos para os hospitais gerais inseridos na malha urbana. Podemos citar como exemplo o Hospital da Colônia Alemã, de 1934, atual Hospital da Aeronáutica, ou mesmo o Hospital dos Servidores, do mesmo ano, cujo projeto chegou a passar pelas mãos de Porto d'Ave, que viu neste a chance de projetar um legítimo hospital monobloco. ${ }^{6}$ Os hospitais de isolamento continuariam a não optar por uma tipologia única, criando um rico repertório em arquitetura para a saúde, que carece de maior atenção dos historiadores.

\section{Os Anos 1930-1940: a arquitetura hospitalar entre duas tipologias e a busca pela limpeza formal}

Nas décadas de 1930 e 1940, as discussões sobre hospital higienista, hospital de isolamento e modelos europeus caminharam para uma uniformidade: a tipologia do pavilhão de isolamento seria mantida para doenças como a tuberculose, a lepra e as de origem mental, e a do monobloco seria adotada pelos hospitais gerais, que deveriam atender aos diversos tipos de doença, segundo o padrão norte-americano.

O que se dizia à época é que os hospitais pavilhonares exigiam grande número de pessoal e altos custos de instalação e manutenção, devendo estar restritos a determinados tratamentos, como o de tuberculosos, para o qual o modelo pavilhonar era preferido ao vertical, pois suas áreas verdes e espaçosas ajudavam na recuperação dos pacientes. No entanto, os pavilhões, em sua grande maioria de um pavimento, estariam mais sujeitos aos efeitos nocivos do contato com a poeira das ruas. Na questão terapêutica, suas instalações não correspondiam à crescente individualização das doenças, restringindose aos que necessitavam de isolamento. Por fim, não se via vantagem em isolar os não contagiosos.

De fato, o monobloco apresentava muitas vantagens sobre o pavilhão, como a redução do custo da compra do terreno e instalação; a economia de transporte, de trajetos e tempo de circulação do pessoal administrativo e do corpo médico e de enfermagem, possibilitada pelo deslocamento vertical proporcionado pelos elevadores; a concentração da administração, disciplina interna e vigilância; a concentração das instalações hidráulicas, térmicas, de esgoto e de eletricidade; maior afastamento dos ruídos e da poeira para os andares mais elevados, entre outras (Brasil, 1965). Em suma, uma solução híbrida, que adotasse os dois modelos, deveria ser, então, a melhor opção. 
Duas políticas públicas de construção de hospitais e de sanatórios são importantes para se entender o que aqui se pretende analisar. Uma se refere às ações do prefeito Pedro Ernesto na primeira metade da década de 1930 e outra diz respeito à política nacional desenvolvida por Getulio Vargas em sua primeira gestão, entre 1937 e 1945. Enquanto a primeira política iria se concentrar na construção de hospitais e dispensários, a segunda, tendência mundial percebida no entre-guerras, usaria os sanatórios como principais elementos de ataque às doenças cujo tratamento dependia de isolamento. Em termos estéticos, a moderna arquitetura apresentada pelos sanatórios adotaria sem parcimônia os padrões do art déco norte-americano, ignorando a hegemonia que a estética moderna do francês Le Corbusier (1887-1965) alcançaria entre os arquitetos da geração modernista (1930-1960).

Paralelamente, a leitura do Código de Obras (decreto 6.000) lançado pelo Distrito Federal em julho de 1937 nos revela outros elementos de análise das propostas de construção dos espaços de cura, no Brasil. No decreto, os hospitais estão separados em três grandes categorias: hospitais gerais; asilos, que incluíam os hospitais de alienados, de crônicos, de tuberculosos e para doentes mentais; e 'gratuitos', talvez se referindo aos postos de assistência e aos ambulatórios. O zoneamento da cidade não permitia a construção de novos hospitais e casas de saúde nas áreas majoritariamente industriais, portuárias e comerciais, mas apenas em algumas zonas residenciais, rurais e agrícolas.

Os asilos deveriam, obrigatoriamente, possuir instalações para administração, composta de direção, secretaria e portaria; assistência, com os gabinetes médico e dentário e enfermaria; local para a permanência dos asilados, com espaços de trabalho, de leitura e recreio; alojamentos, separados para as diversas classes de pacientes, enfermeiros ou zeladores e pessoal de serviço; refeitórios, igualmente com as mesmas separações; serviços gerais, compreendendo copa, cozinha, despensa, lavanderia, incinerador de lixo etc.; velório. Para os asilos de crianças exigiam-se, ainda, instalações de campos para jogos e ginásio. O decreto ditava as dimensões dos espaços internos, altura dos pés-direitos (3,2 m) e o que deveria constar em cada enfermaria: salas de curativo, tratamento e serviços médicos; copa; rouparia; pequena farmácia e instalações sanitárias e banheiros.

Para os hospitais, era obrigatório que o programa contasse com cozinha, lavanderia, necrotério e incineradores de lixo. O decreto, além de estabelecer diretrizes quanto ao tamanho dos pés-direitos, um pouco mais baixos que para os sanatórios $(3,0 \mathrm{~m})$, dos corredores e dos espaços internos, exigia o uso de matérias resistentes, impermeáveis e laváveis, como cerâmicas e ladrilhos, nos pisos e nas paredes, até a altura de 1,5 m, para os corredores de circulação, banheiros e cozinhas. Nas construções com mais de dois pavimentos, deveriam ser instalados elevadores. Os dormitórios de doentes deveriam obedecer à melhor orientação solar, protegendo os vãos, como janelas e portas, da incidência do sol, por meio de varandas, marquises e anteparos naturais, como vegetação, ou artificiais, como persianas. As construções deveriam ainda permitir a ventilação permanente dos dormitórios, aproveitando a melhor direção dos ventos oferecida pelo terreno. O decreto traduzia e reunia, assim, séculos de experiência na construção de espaços de cura, preparando-os para a modernidade, de forma mais organizada.

Na gestão de Pedro Ernesto na Prefeitura do Distrito Federal adotou-se um plano de construção de hospitais policlínicos regionais e de dispensários, entre 1931 e 1934. À frente da construção desses hospitais estava Luiz Moraes Jr., o mesmo construtor de Manguinhos. A sua Companhia Industrial Construtora do Rio de Janeiro, em sociedade com Archimedes d'Arthagnam Saldanha, realizou a maioria das obras. 
A linguagem plástica adotada nesses edifícios almejava uma modernidade ainda embrionária, com fortes referências ao art déco de origem norte-americana, sendo identificada como um 'protomodernismo'; procurava, à sua maneira, romper com os 'estilos' até então adotados para as construções hospitalares, que ora faziam referências ao gótico alemão, ora ao neoclássico, ora ao romantismo francês. O que se buscou foi a limpeza formal, com destaque para as varandas, sem abandonar por completo o uso de esquinas e acessos destacados, de ornamentação, minimamente reduzida a frontões estilizados, e de marcações e linhas cubistas.

Por sua vez, a Divisão de Obras do Ministério de Educação e Saúde atuou entre 1934 e 1953, e depois até 1977, para o Ministério da Saúde, na construção de edifícios para todo o país, como responsável por elaborar os programas arquitetônicos, os projetos, organizar as especificações e os orçamentos, executar e fiscalizar as obras (Oliveira, Costa \& Pessoa, 2003). Ao longo desse período, a equipe projetou e construiu, com verbas do ministério, de 13 a 19 grandes sanatórios em praticamente todos os estados da nação, incluindo o de Santa Maria, em Jacarepaguá (1937-1943). ${ }^{7}$ Em Porto Alegre, construiu o Hospital Sanatório Belém, em parceria com a sociedade filantrópica de mesmo nome. Essa estratégia de criação de leitos para o tratamento de tuberculosos contou com hospitais especializados e hospitais, entre privados e públicos, que mantinham leitos para esses doentes, o que ficou caracterizado como a Cruzada Sanitária da Era Getuliana. A linguagem arquitetônica, dependendo do autor do projeto - entre eles, certamente, Jorge Ferreira -, se apresentava mais ousada, adotando a estética proposta por Le Corbusier: ausência de ornamento, estrutura aparente, planta livre, a idéia do protótipo e a possibilidade de reprodução industrial (Cavalcanti, 2006).

Outra equipe foi a de Engenharia e Arquitetura da Campanha Nacional Contra a Tuberculose (CNCT), criada em 1946, sob a orientação e fiscalização do Serviço Nacional de Tuberculose, do Departamento Nacional de Saúde do Ministério da Educação e Saúde (MES). Essa equipe contava em seus quadros com arquitetos como Sérgio Bernardes e Jorge Machado Moreira, que, como Jorge Ferreira, adotavam mais claramente uma estética corbusiana.

A campanha atuava no combate principalmente da tuberculose do tipo óssea e do tipo pulmonar. Para cada doença um modelo de terapia, com especial reflexo na arquitetura. Para o tratamento da tuberculose do tipo óssea era recomendada a helioterapia, que consistia, basicamente, na exposição do doente ao sol, por várias horas ao dia. E para a pulmonar, o mais importante eram o ar e a ventilação. Para podermos comparar um modelo com o outro, tomemos como exemplos o Sanatório de Santa Maria, para o primeiro caso, e o de Curicica para o segundo. O de Santa Maria foi projetado pela equipe da Divisão de Obras, entre 1937 e 1943, e o de Curicica pelo escritório de engenharia e arquitetura da CNCT, entre 1949 e 1952, tendo à frente Sérgio Bernardes.

Para o Sanatório de Santa Maria, foi adotada a construção em monobloco, situada em uma grande área verde. Sua planta consiste na junção de dois Ys, esquema comum a esses sanatórios, que se utilizavam também da planta em V, como forma de evitar os efeitos dos ventos fortes, que, nesse caso, eram prejudiciais ao tratamento (Bittencourt, 2000). As varandas de cura posicionavam-se nas 'pernas' dos Ys, e no centro ficavam as áreas comuns, como administração, salas de cirurgia, cozinha, lavanderia etc. As varandas são o ponto de destaque da edificação: lugar de exposição ao sol e da contemplação do sítio circundante. 
No Sanatório de Curicica, por sua vez, preferiu-se o tradicional sistema de pavilhões de um pavimento espalhados por uma extensa área verde, embora pelo mundo esse sistema estivesse em franco desuso. Reconhecia-se nessa tipologia um fator importante para o tratamento da tuberculose pulmonar, além de forma de evitar o estado de reclusão percebido nos doentes internados nos sanatórios em monoblocos, o que levou a CNCT a projetar o conjunto sanatorial com aquelas características.

O programa arquitetônico seguiu as premissas técnicas elaboradas pelo Serviço Nacional da Tuberculose, previamente aprovado pelo MES, cujas recomendações gerais seguiam o estudo e a padronização da construção de sanatórios e dispensários tipo campanha: eficiência, baixo custo e manutenção econômica, sem, entretanto, sacrificar suas qualidades técnicas, funcionais e arquitetônicas. Era preciso igualmente dotar suas instalações de espaços que favorecessem a capacitação profissional e o convívio social dos doentes, por meio de oficinas, áreas de lazer, de culto religioso e de entretenimento.

Como vimos, ao longo da década de 1930 até os anos 50, os sistemas pavilhonar e monobloco disputavam a preferência de médicos e arquitetos nas modernas construções para a saúde, com predominância dos primeiros, mesmo diante da grande diversidade de categorias de hospitais então verificada. ${ }^{8} \mathrm{O}$ ano de 1967 , entretanto, seria definitivo para a mudança desse quadro.

\section{Anos 1950-60: o hospital tecnológico e a triunfante arquitetura monobloco vertical}

A década de 1950 foi exemplar para a discussão do que seria considerado um moderno hospital, conduzida, dessa vez, por arquitetos. Usamos como base a publicação de 1954 da Comissão de Planejamento de Hospitais do Instituto de Arquitetos do Brasil, departamento de São Paulo (IAB-SP). Essa publicação, Planejamento de Hospitais, foi fruto das aulas e dos debates realizados por ocasião do curso de Planejamento de Hospitais oferecido pelo instituto entre 13 e 17 de abril de 1953, em São Paulo, do qual participaram arquitetos, engenheiros, médicos, enfermeiras e estudantes das respectivas áreas.

Os objetivos desse curso, segundo consta na introdução da publicação, eram, entre outros, "divulgar conquistas no campo de planejamento de hospitais, analisar os elementos essenciais a um projeto são e científico, possibilitar a construção de hospitais eficientes (...), aproximar interessados, e estimular o intercâmbio de informações e pesquisa" (Prado, Karman \& Levi, 1954: 13-14).

Quanto à maior contribuição do arquiteto, Rino Levi, um dos participantes do curso, tinha consciência de que esta se daria na forma plástica final do projeto, como em qualquer outro projeto arquitetônico. Mas, no caso do hospital, a estética estava aliada a uma vontade de organizar um serviço que, na sua opinião, contribuiria para uma investigação científica mais ampla, em substituição a controvérsias e a critérios pessoais e empíricos no planejamento de um programa dos mais complexos (Levi, 1954).

Para os participantes em geral, a grande contribuição da arquitetura moderna seria transformar o hospital em uma construção monobloco, onde se poderia demonstrar todo o rigor de uma construção sólida, imponente, digna de uma arquitetura racional, bem planejada e bem construída. Uma construção que se preocupasse com a localização na malha urbana existente, com a insolação, a ventilação, as circulações, os fluxos, a estrutura, as instalações e os detalhes.

Os edifícios hospitalares em monobloco construídos no Rio de Janeiro nos anos 1950 procurariam seguir tais recomendações, a exemplo dos hospitais da Lagoa; dos Radialistas; do Câncer, na praça da 
Cruz Vermelha; de Ipanema; do Andaraí e das Clínicas da Faculdade de Medicina, que se revelaram bons projetos.

O Hospital da Lagoa, projetado por Oscar Niemeyer e Hélio Uchoa, com paisagismo de Burle Marx, passa para a historiografia brasileira como a grande expressão de hospital da tipologia monobloco do período moderno. Seus detalhes arquitetônicos, como o pilar em V e a estrutura em arco do bloco do auditório, revelam grande apuro técnico e estético. Especialmente importante, o pilar, criação de Niemeyer baseada no repertório formal lançado pelo modernismo internacional, foi primeiramente utilizado nesse hospital, merecendo a atenção do historiador francês Yves Bruand (1981). A edificação do Hospital da Lagoa é um dos poucos exemplares modernos tombados por um organismo de proteção patrimonial e tem sua importância no rigor com que nela foram aplicados os preceitos de um moderno hospital monobloco.

As doenças foram separadas por seus dez pavimentos; a circulação de doentes, pessoal e de serviço foi facilitada pela construção de amplos corredores e de um prisma de circulação vertical, destacado do bloco principal. As áreas destinadas ao convívio social foram localizadas no térreo. Os quartos dos doentes, as salas dos médicos e de operação foram posicionados para a melhor insolação e a melhor vista, de frente para a lagoa Rodrigo de Freitas. As salas de serviço ficaram voltadas para a rua Jardim Botânico; para proteção contra o sol, adotaram-se tijolos vazados e brise-soleils verticais.

Em 1957, foi desenvolvido pelo Escritório Técnico da Universidade do Brasil (ETBU), sob a chefia de Jorge Machado Moreira, o projeto do Hospital Universitário Clementino Fraga Filho, para o então Hospital de Clínicas da Universidade do Brasil. Projetada para atender ao programa de um hospital-escola com dois mil leitos, foi construída uma grandiosa estrutura de $220.000 \mathrm{~m}^{2}$, adotando a tipologia do hospital monobloco. Mas, ainda hoje, funciona apenas metade de suas instalações, localizadas na ilha do Fundão.

Tal projeto seria a grande referência para o hospital monobloco no Rio de Janeiro e no Brasil, juntamente com o do Hospital das Clínicas de São Paulo e o de Porto Alegre, ambos de Moreira. Um dos autores da Comissão do Plano da Universidade do Brasil, e posteriormente ministro da Educação, Ernesto de Souza Campos, chegou a afirmar, no prefácio da reedição da obra História e Evolução dos Hospitais, usando os projetos de Moreira como referência, que a década de 1950 foi o período da renovação hospitalar, o que obrigou especialmente os arquitetos a debaterem o assunto (Campos, 1965). Publicada primeiramente em 1944, a cargo da Divisão de Organização Hospitalar do Departamento Nacional de Saúde, essa obra traria importantes contribuições para o debate, abrindo um campo de reflexão sobre a construção de hospitais e sua arquitetura especializada e extremamente funcional. Criada em 1941, com base no modelo do American College of Surgeons, a divisão se tornou uma referência para o tema, especialmente nas duas décadas seguintes, ao oferecer cursos de Organização e Administração Hospitalares, a exemplo que faria o IAB em 1953-1954.

Para o arquiteto Jarbas Karman (1954: 175), diretor do curso oferecido pelo IAB, o hospital moderno era "uma das mais complexas, dinâmicas e especializadas instituições. Dia a dia, novas aplicações, pesquisas e descobertas o vêm transformando. Gradativamente, o que ainda resta de empírico e tradicional dará lugar ao científico e ao racional".

Karman baseava suas impressões nos estudos da Divisão Hospitalar do Serviço de Saúde Pública dos Estados Unidos (U.S. Public Health Service). Em seu texto, o arquiteto se preocupava não somente com a solução plástica final, uma combinação de elementos formais de diversos tipos de plantas arquitetônicas 
(em I, L, V, U, X, Y), mas também com itens que vão desde a disposição interna de cada aparelho, sala, centro médico e cirúrgico, associada ao detalhamento das medidas de cada espaço e cada área de circulação - vertical e horizontal, fluxos -, áreas limpas, áreas sujas, sociais e de serviço, enfermarias gerais e de isolamento, até o detalhamento de armários, portas, sistemas de ventilação, instalações etc., demonstrando a extrema complexidade de uma construção hospitalar contemporânea à época.

Em 1967, o governo federal proibiu a criação de novos leitos para tuberculosos e os hospitais gerais passaram a oferecer tratamento para esses doentes, o que exigiu reformas e ampliações em suas instalações, na maioria obsoletas. Essas reformas se concentraram na construção de monoblocos anexos ou em substituição aos antigos edifícios, grandes lâminas verticais de cinco, sete ou dez pavimentos. Podemos citar como exemplos os hospitais Salgado Filho, Rocha Faria, Getulio Vargas, Miguel Couto, Souza Aguiar, Pedro II e Carlos Chagas.

As discussões da década anterior seriam plenamente aproveitadas e o monobloco, enfim, reinava absoluto.

\section{Arquitetura e Medicina: entre a teoria e a prática}

Como procuramos evidenciar aqui, há muito ainda que se refletir sobre as relações entre arquitetura e saúde. A arquitetura pode ser entendida como materialização da evolução da cultura humana, juntamente com a escultura, se expressando por meio de suas formas e espaços construídos. Na saúde, os maiores desafios se impuseram na tentativa de aliar os preceitos da medicina com os materiais construtivos utilizados à época, a geografia, o clima e a expressão plástica. Das construções feitas à semelhança de igrejas e templos religiosos aos edifícios compactos e extremamente funcionais, construídos no coração das cidades ou fora delas, investidos de missões de caridade ou sanitárias e higiênicas, os espaços de saúde, em especial os hospitais, sempre estiveram permeados por seu contexto político, social, econômico, médico e arquitetônico.

$\mathrm{O}$ que pretendemos analisar aqui foi o modo como os arquitetos, engenheiros e construtores, associados aos médicos até um determinado momento, procuraram responder, entre a prática e a teoria e com razão e engenhosidade, aos desafios da construção de espaços de saúde no Rio de Janeiro. Como vimos, a salubridade das águas, do ar e do lugar sempre foram determinantes para uma boa arquitetura. Especialmente para os hospitais, casas de saúde e sanatórios, a fórmula de uma boa arquitetura acrescenta o diálogo afinado com as teorias médicas.

Em comum com outras cidades do Novo Mundo, a história da arquitetura hospitalar se iniciou entre nós na relação de cumplicidade primeiramente com a religiosidade. Aos poucos, os espaços, ao mesmo tempo que se transformavam de ambientes de morte em ambientes de cura, foram ganhando autonomia, inclusive formal. Subordinados à busca por amplos espaços, externos e internos, e procurando contribuir no combate a uma cada vez maior individualização das doenças e de seus tratamentos, os espaços de saúde procuraram multiplicar e aperfeiçoar os ambientes de cura, almejando excelência terapêutica.

A arquitetura se propôs a acompanhar esses desafios. Quando a função do hospital era amparar o doente até a morte, expressava-se como legítimos monastérios, de construção sólida e robusta, lugar de recolhimento e contemplação. Diante da necessidade de buscar melhores condições para a recuperação 
e cura de seus pacientes, a arquitetura hospitalar procurou se tornar mais leve, abrindo vãos e pátios, aumentando a altura dos pés-direitos internos, descobrindo e adotando materiais e recursos construtivos para o melhor aproveitamento do ar e do sol saudável. No Rio de Janeiro, os hospitais deveriam seguir as direções NNE e NNO, a direção mais satisfatória - verão e inverno - para se proteger da insolação, preceito conhecido desde os primeiros estudos de Vicente Licínio Cardoso (1927) realizados na década de 1920 acerca da arquitetura hospitalar. ${ }^{9}$

A resposta estética apareceu inicialmente na forma ordenada e harmoniosa da arquitetura clássica, conjugada com a arquitetura francesa dos challets: ritmo e austeridade convivendo com rendilhados, venezianas, azulejos, ladrilhos hidráulicos e painéis decorativos. Depois, com a modernidade impondo respostas cada vez mais eficazes, os locais de saúde passaram a rejeitar os rebuscamentos, adotando o lema "menos é mais", ${ }^{10}$ e a se concentrar na eficiência de seus espaços e no propósito de suas construções, sempre aliados ao diálogo com as indicações médicas, no caso das construções hospitalares. Se o tratamento exigia mais contato com o sol, construíam-se sanatórios de amplas varandas. Se o objetivo era usufruir mais do ar saudável, mantinham-se os pavilhões espalhados por grande área verde. Se o sol precisava ser controlado, evitava-se a exposição exagerada, usando-se os recursos das persianas, tijolos vazados, marquises, vegetação natural. Se a idéia era evitar a poeira e o barulho das ruas, elevava-se a construção, criando-se verdadeiros arranha-céus da saúde.

As linguagens arquitetônicas se expressaram das mais variadas formas, indo da referência à cultura clássica ao modo de vida elegante das casas francesas, do colonialismo português aos hospitais-cidade alemães e às perenes tent-houses americanas, do protomodernismo americano ao racionalismo europeu, sem que isso, insistimos, tenha representado uma evolução linear e progressiva. Hoje se reconhece que o ponto fraco dos hospitais verticais e compactos está em não aproveitar o melhor contato com o ambiente externo, o que os torna sempre dependentes de mecanismos artificiais. Busca-se a volta ao uso de jardins e do ar natural para uma melhor recuperação dos pacientes.

A cidade do Rio de Janeiro conta com bons exemplos de bens imóveis relacionados à saúde registrados em livros de tombo por seu valor histórico e/ou arquitetônico, englobando variadas linguagens e períodos construtivos. Graças à atuação das três instâncias de proteção, federal, estadual e municipal, temos protegidos o Hospital da Santa Casa da Misericórdia, o Hospital das Crianças da Santa Casa da Misericórdia, o Núcleo Histórico da Fiocruz, o conjunto da antiga Colônia Juliano Moreira, os hospitais São Francisco de Assis, Moncorvo Filho, da Cruz Vermelha, da Lagoa, Gaffrée \& Guinle, Frei Antonio, Ordem Terceira da Penitência, o conjunto da Beneficência Portuguesa, a Escola de Enfermagem Anna Nery, a Caixa de Socorros D. Pedro V, o Instituto Nacional de Educação de Surdos e a Casa de Saúde Dr. Eiras.

Esse repertório, em grande medida ainda não totalmente difundido, somado ao estudado nesta publicação, precisa ter seu devido valor reconhecido e elevado à categoria de patrimônio cultural da saúde da cidade do Rio de Janeiro. 


\section{Notas}

${ }^{1}$ Rino Levi (1901-1965) realizou em São Paulo os projetos da Maternidade da Universidade de São Paulo, em 1945, do Hospital Central do Câncer, 1947, do Hospital da Cruzada Pró-Infância, 1950, do Hospital Albert Einstein, 1958; na Venezuela, os do Hospital Central de Caracas, 1959, de Maiquetia, 1959, e de Puerto Cabello, 1960 (Anelli, Guerre \& Nelson, 2001).

2 Por partido arquitetônico entende-se um conjunto de diretrizes que norteiam a elaboração do projeto de arquitetura, incluindo opção estética, definição de uso, elementos construtivos, recursos etc.

${ }^{3}$ Conforme descrição arquitetônica elaborada por Inês El-Jaick Andrade para o verbete do Hospital São Francisco de Assis, para esta publicação (no CD-ROM encartado).

${ }^{4} \mathrm{~A}$ autora se refere aos médicos exploradores, aqueles que participavam de viagens empreendidas no contexto de empresas colonialistas européias; tais profissionais realizavam um amplo mapa nosográfico dos países situados nas colônias, a chamada geografia médica.

${ }^{5}$ Luiz Moraes Jr. se tornaria grande referência em arquitetura para a saúde no Rio de Janeiro na primeira metade do século XX. Sua aproximação com a área deveu-se ao convite de Oswaldo Cruz para a realização dos projetos dos edifícios do então Instituto Soroterápico (1905-1917). A relação do arquiteto com o instituto foi mantida na gestão de Carlos Chagas (1917-1934). Além das obras em Manguinhos, Moraes seria o responsável pelo projeto e construção da Policlínica da Avenida Central (1904), do Desinfectório de Botafogo (atual Hospital Rocha Maia, 1905), pelas reformas do Hospital do Engenho de Dentro (1908), pelos projetos de novos pavilhões, reforma e construção de pavilhões do Hospital São Sebastião (1908) e de Jurujuba (1909). Já a inserção de Porto d'Ave na arquitetura hospitalar deveu-se ao mecenato de Guilherme Guinle. A aproximação entre eles foi facilitada pelo fato de sua cunhada Gilda ter sido casada com Carlos Guinle, irmão de Guilherme. Na década de 1920, Guilherme Guinle financiou a construção de três hospitais para a saúde pública, durante a gestão de Carlos Chagas no DNSP (Sanglard, Costa \& Mello, 2007).

${ }^{6}$ Porto D'Ave foi vencedor em concurso de arquitetura realizado em 1934 para o Hospital dos Servidores. Todavia, a construção do hospital se arrastou por uma década e o projeto construído sofreu modificações, cabendo sua autoria final ao engenheiro Dulphe Pinheiro Machado, com colaboração do médico Felix Lamela (Sanglard \& Costa, 2007).

7 Segundo dados do Fundo Gustavo Capanema, do Centro de Pesquisa e Documentação História Contemporânea do Brasil da Fundação Getulio Vargas (Cpdoc/FGV), foram projetados sanatórios para tuberculosos nos estados do Distrito Federal (Sanatório de Santa Maria, em Jacarepaguá), Pará (Sanatório de Belém, 1938), Pernambuco (Sanatório Otávio de Freitas, em Recife, 1939-1946), Ceará (Sanatório de Fortaleza, 1938), Espírito Santo (Sanatório Getulio Vargas, em Vitória, 1938-1942), Rio de Janeiro (Sanatório Azevedo Lima, em Niterói, 1939-1946), Rio Grande do Norte (Sanatório de Natal, 1939), Maranhão (Sanatório de São Luis, 1939), Sergipe (Sanatório de Aracaju, 1939-1941), Alagoas (Sanatório General Severiano da Fonseca, em Maceió, 1939-1946), São Paulo (Sanatório de Mandaqui, 1939), Paraíba (Sanatório Clementino Fraga, 1941-1946), Piauí (anexo ao Hospital Getulio Vargas, 1941-1944), Minas Gerais (Sanatório Getulio Vargas, projetado mas não construído), Mato Grosso (Sanatório de Campo Grande, projetado mas não construído), Bahia (Sanatório São Gonçalo dos Campos, projetado mas não construído), Goiás (projetado mas não construído), Amazônia (projetado mas não construído) e Acre (projetado mas não construído).

${ }^{8}$ Segundo publicação do IAB, Planejamento de Hospitais (Prado, Karman \& Levi, 1954), a assistência hospitalar se dividia em geral e especializada. Além dos hospitais gerais e especializados, eram considerados especiais os hospitais do tipo colônia, vila, asilo, sanatório, prisão, de emergência, móvel, de ensino e navio. Na mesma publicação propunha-se uma nova classificação mais simples: hospitais do tipo clínica ou policlínica, dispensário, ambulatório, estância de cura, asilo, abrigo, albergue, hidromineral, termal, balneário e climático. Para os hospitais especializados, entretanto, propunha-se uma classificação detalhada que abrangia trinta itens diferentes, entre aqueles destinados a doenças cardíacas; doenças transmissíveis; câncer; doenças mentais; da garganta, nariz e ouvidos; maternidade; para crianças, velhos, surdos-mudos, aleijados etc.

${ }^{9}$ Cito o trabalho de Vicente Licínio Cardoso, em tese apresentada ao concurso para professor da Escola Politécnica, na cátedra de Arquitetura e Construção Civil. Em 1927, Cardoso escreve os Princípios Geraes Modernos de Hygiene Hospitalar, em que traça a evolução do hospital moderno a partir de 1786, com o surgimento do hospital pavilhonar na França, em reação aos tipos herdados da Idade Média e da Renascença, até os melhores exemplos de hospitais nos Estados Unidos, chegando a analisar especificamente as construções cariocas.

${ }^{10}$ Lema preconizado por Adolf Loos em 1908, quando do lançamento de sua publicação Ornamento e Crime, onde ele desenvolve os princípios do modernismo que levou à rejeição do ornamento como elemento compositivo e formal. 


\section{Referências}

ANELLI, R.; GUERRA, A. \& NELSON, K. Rino Levi: arquitetura e cidade. São Paulo: Romano Guerra Editora, 2001.

BITTENCOURT, T. Peste Branca, Arquitetura Branca: os sanatórios de tuberculose no Brasil na primeira metade do século vinte, 2000. Dissertação de Mestrado, São Carlos: Instituto Escola de Engenharia, Universidade de São Carlos.

BRASIL. Código de Obras e Legislação Complementar. Decreto 6.000, de 1 de julho de 1937.

BRASIL. História e Evolução dos Hospitais [1944]. Rio de Janeiro: Divisão de Organização Hospitalar/Departamento Nacional de Saúde/Ministério da Saúde, 1965.

BRUAND, Y. Arquitetura Contemporânea no Brasil. São Paulo: Perspectiva, 1981.

CAMPOS, E. S. Proêmio. In: BRASIL. História e Evolução dos Hospitais [1944]. Rio de Janeiro: Divisão de Organização Hospitalar/Departamento Nacional de Saúde/ Ministério da Saúde, 1965.

CARDOSO, V. À Margem da Arquitetura Grega e Romana e Princípios Geraes Modernos de Hygiene Hospitalar. Rio de Janeiro: Typographia do Anuário do Brasil, 1927.

CARMO, J. Contribuição ao Estudo da Evolução do Hospital em Higiene Pública, 1948. Tese apresentada para concurso de professor catedrático de higiene e legislação farmacêutica na Faculdade Nacional de Farmácia da Universidade do Brasil.

CAVALCANTI, L. Moderno e Brasileiro: a história de uma nova linguagem na arquitetura (1930-1960). Rio de Janeiro: Jorge Zahar, 2006.

DESAI, M. Docomomo Journal, n. 35, p. 11, set. 2006.

FAURE, O. Histoire Sociale de la Médecine (XVIII ${ }^{e}$ XXè siècles). Paris: Anthropos Histhoriques, 1994.

FOUCAULT, M. Microfísica do Poder. 17. ed. Rio de Janeiro: Graal, 1999.

História e Patrimônio Cultural da Saúde. Termo de constituição da Rede de História e Patrimônio Cultural da Saúde. Casa de Oswaldo Cruz. Rio de Janeiro, set. 2006. (Mimeo.)

KARMAN, J. B. Unidade de centro cirúrgico e centro de material e de esterilização. In: PRADO, A. C.; KARMAN, J. B. \& LEVI, R. Planejamento de Hospitais. São Paulo: IAB-SP, 1954.

LEVI, R. Planejamento de hospitais sob o ponto de vista do arquiteto. In: PRADO, A. C.; KARMAN, J. B. \& LEVI, R. Planejamento de Hospitais. São Paulo: IAB-SP, 1954.

MACHADO, R. et al. Danação da Norma: medicina social e constituição da psiquiatria no Brasil. Rio de Janeiro: Graal, 1978.

MIQUELIN, L. C. Anatomia dos Edifícios Hospitalares. São Paulo: Cedas, 1992.

MIGNOT, C. Architecture of the $19^{\text {th }}$ Century. Colonia: Evergreen, 1983.

MORAIS, R. A geografia médica e as expedições francesas para o Brasil: uma descrição da estação naval do Brasil e da Prata (1868-1870). História, Ciências, Saúde-Manguinhos [on-line], 14(1): 39-62, 2007. Disponível em: <www.scielo.br/scielo.php?script=sci_arttext\&pid=S0104-59702007000100003\&lng=pt\&nrm=iso $>$. Acesso em: 13 nov. 2007.

OLIVEIRA, B.; COSTA, R.; PESSOA, A. Um Lugar para a Ciência: a formação do campus de Manguinhos. Rio de Janeiro: Editora Fiocruz, 2003.

PÔRTO, A. \& OLIVEIRA, B. Edifício colonial construído pelos jesuítas é lazareto desde 1752 no Rio de Janeiro. História, Ciências, Saúde - Manguinhos [on-line], 2(3): 171-174, 1996. Disponível em: <www.scielo.br/ scielo.php?script=sci_arttext\&pid=S0104-59701996000400009\&lng=pt\&nrm=iso $>$. Acesso em: 13 nov. 2007.

PRADO, A. C.; KARMAN, J. B.; LEVI, R. Planejamento de Hospitais. São Paulo: Instituto de Arquitetos do Brasil de São Paulo, 1954.

RUSSEL-WOOD, A. Fidalgos e Filantropos: a Santa Casa da Misericórdia da Bahia, 1550-1755. Brasília: Editora UnB, 1981.

SANGLARD, G. \& COSTA, R. G. R. Direções e traçados da assistência hospitalar no Rio de Janeiro, $1923-1931$. História, Ciências, Saúde - Manguinhos, 11(1):107-141, 2004. 
HISTÓRIA DA SAÚDE NO RIO DE JANEIRO

SANGLARD, G. \& COSTA, R. G. R. (Orgs.) Porto d'Ave: projetos para a saúde. Catálogo exposição, 2007.

SANGLARD, G.; COSTA, R. G. R. \& MELLO, M. T. B. A coleção Porto d'Ave e a assistência hospitalar no Rio de Janeiro, 1920. Revista do Instituto Histórico e Geográfico Brasileiro, 435: 195-208, 2007.

TOLEDO, L. Feitos para Curar: arquitetura hospitalar e processo projetural no Brasil. Rio de Janeiro: ABDEH, 2006.

TOLLET, C. Les Édifices Hopitaliers: depuis leur origine jusqu'à nos jours. 10 ed. Paris: s. n., 1892

TUNDIS, S. \& COSTA, N. Cidadania e Loucura: políticas de saúde mental no Brasil. Rio de Janeiro: Vozes, 1990.

Bibliografia complementar

COSTA, R. Healthcare in Brazil. 1930-1960: preserving the modern architectural legacy. Docomomo Journal, n. 37, Sept. 2007.

CREMNITZER, J-B. Architecture et Santé: les temps du sanatorium en France et Europe. Éditions A. et J. Picard, 2005.

NASCIMENTO, D.; COSTA, R.; PESSOA, A.; MELLO, E. Sanatório de Curicica: um Sérgio Bernardes pouco conhecido, 2003. Disponível em: <www.vitruvius.com.br>.

RIBEIRO, L. A Luta contra a Tuberculose no Brasil: apontamentos para a sua história. Rio de Janeiro: Editorial SulAmericana, 1956.

SEGAWA, H. Arquitetura na Era Vargas: o avesso da unidade pretendida. In: PESSOA, J. et al. (Orgs.) Moderno e Nacional. Niterói: EdUFF, 2006. 


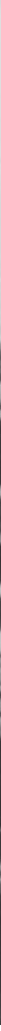

Vista da Exposição, 1922. Foto Augusto Malta. Acervo Arquivo Geral da Cidade do Rio de Janeiro

Vista do morro do Castelo para o Hospital Geral da Santa Casa, mostrando a disposição dos pátios internos da construção neoclássica e sua localização privilegiada.

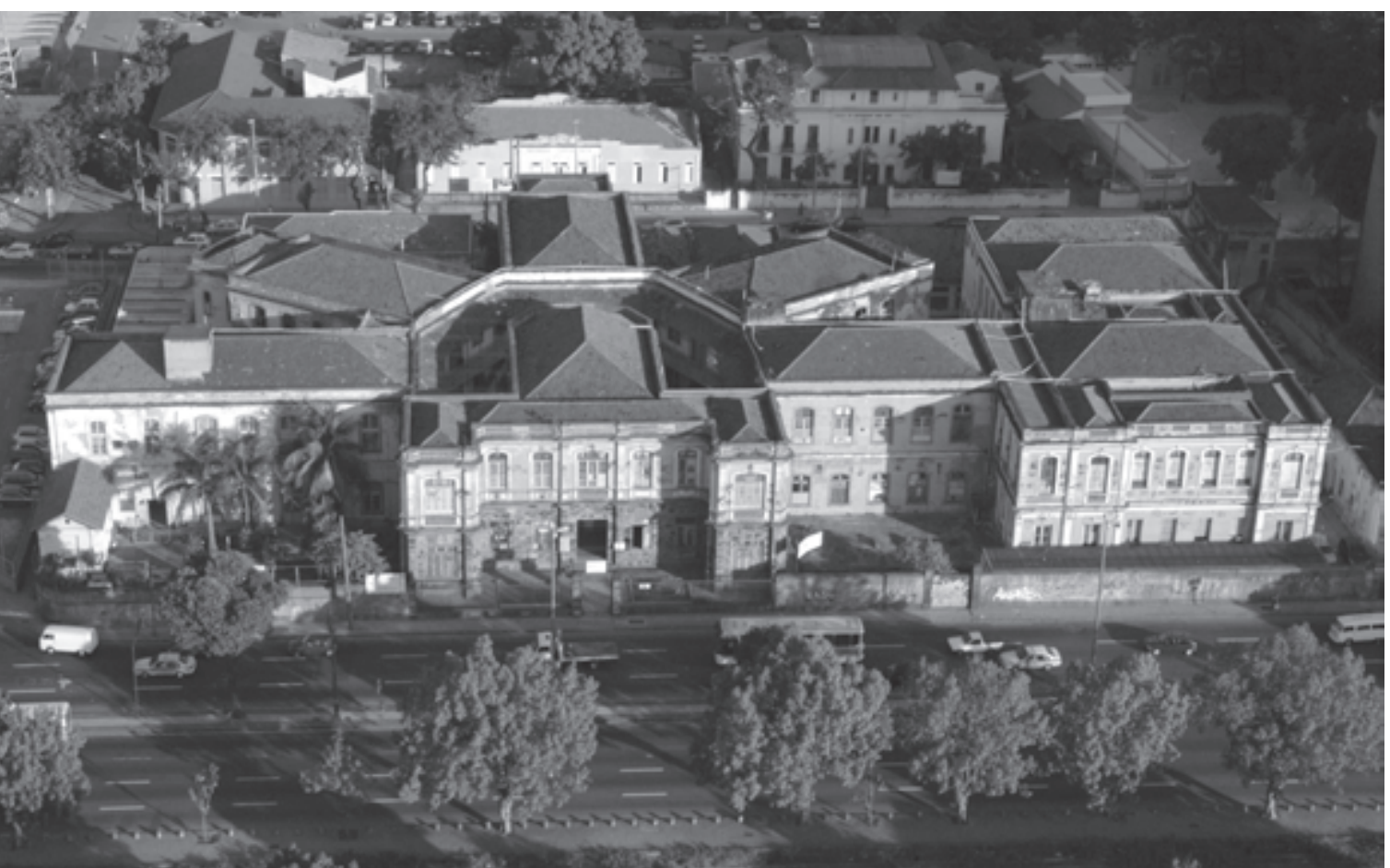

Hospital São

Francisco de

Assis, [s.d.]. Acervo

Universidade

Federal do Rio de

Janeiro

Vista aérea do

conjunto

evidenciando a

disposição dos

pavilhões em

forma radial

(paróptico). 


\section{Hospital São}

Sebastião, [s.d.].

Fonte: Oswaldo

Cruz Monumenta Histórica. Acervo

Biblioteca da

Casa de Oswaldo

Cruz/Fiocruz

Interior de um dos pavilhões de isolamento do Hospital São Sebastião. Em destaque, à esquerda, as telas de separação para os leitos dos pacientes infectados.
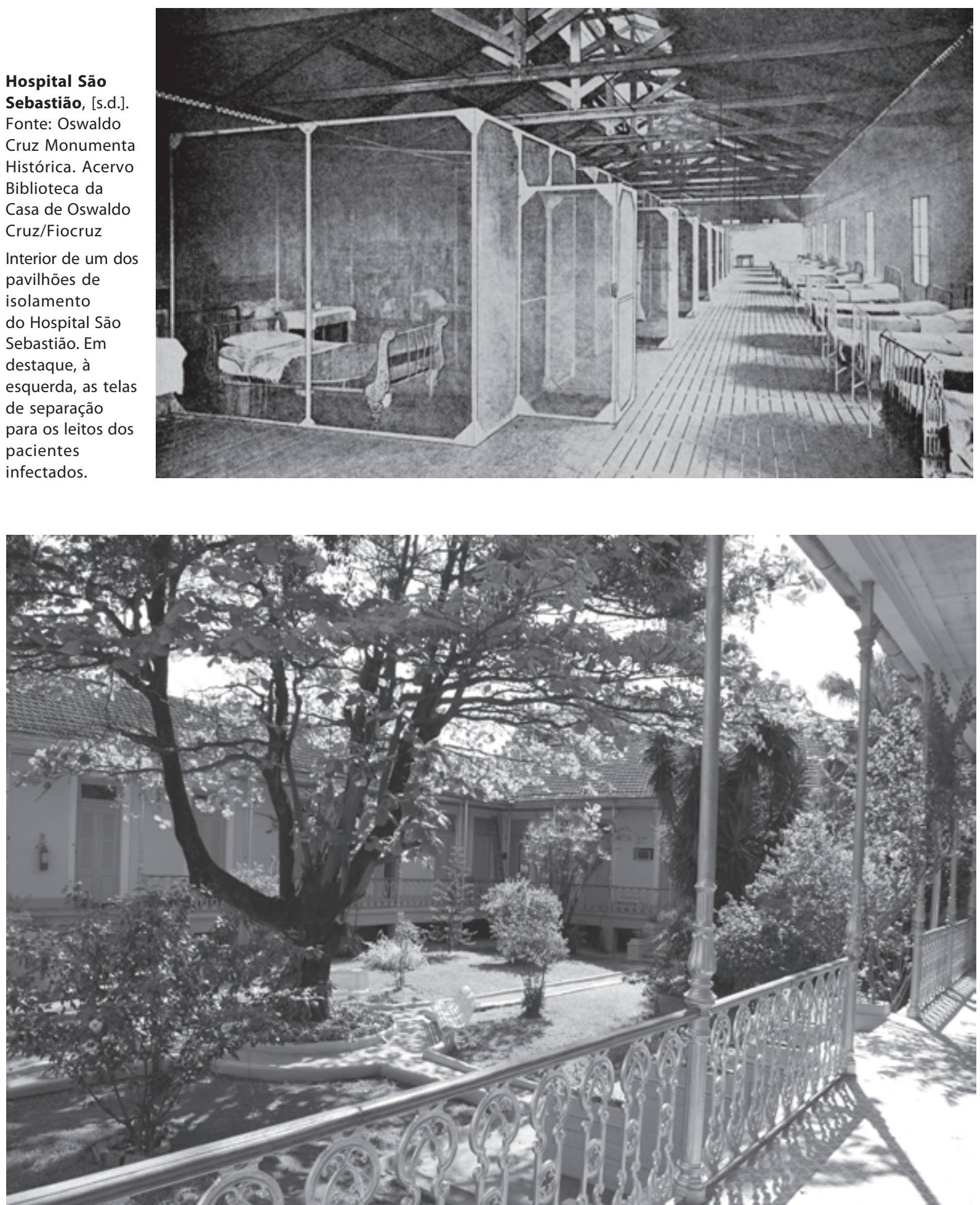

Hospital Evangélico, 2008. Foto Roberto Jesus Oscar e Vinícius Pequeno. Acervo Casa de Oswaldo Cruz

Vista do pátio interno do Hospital Evangélico, criado para facilitar a aeração e a ventilação dos quartos, proposta clara da tipologia dos hospitais higienistas. 


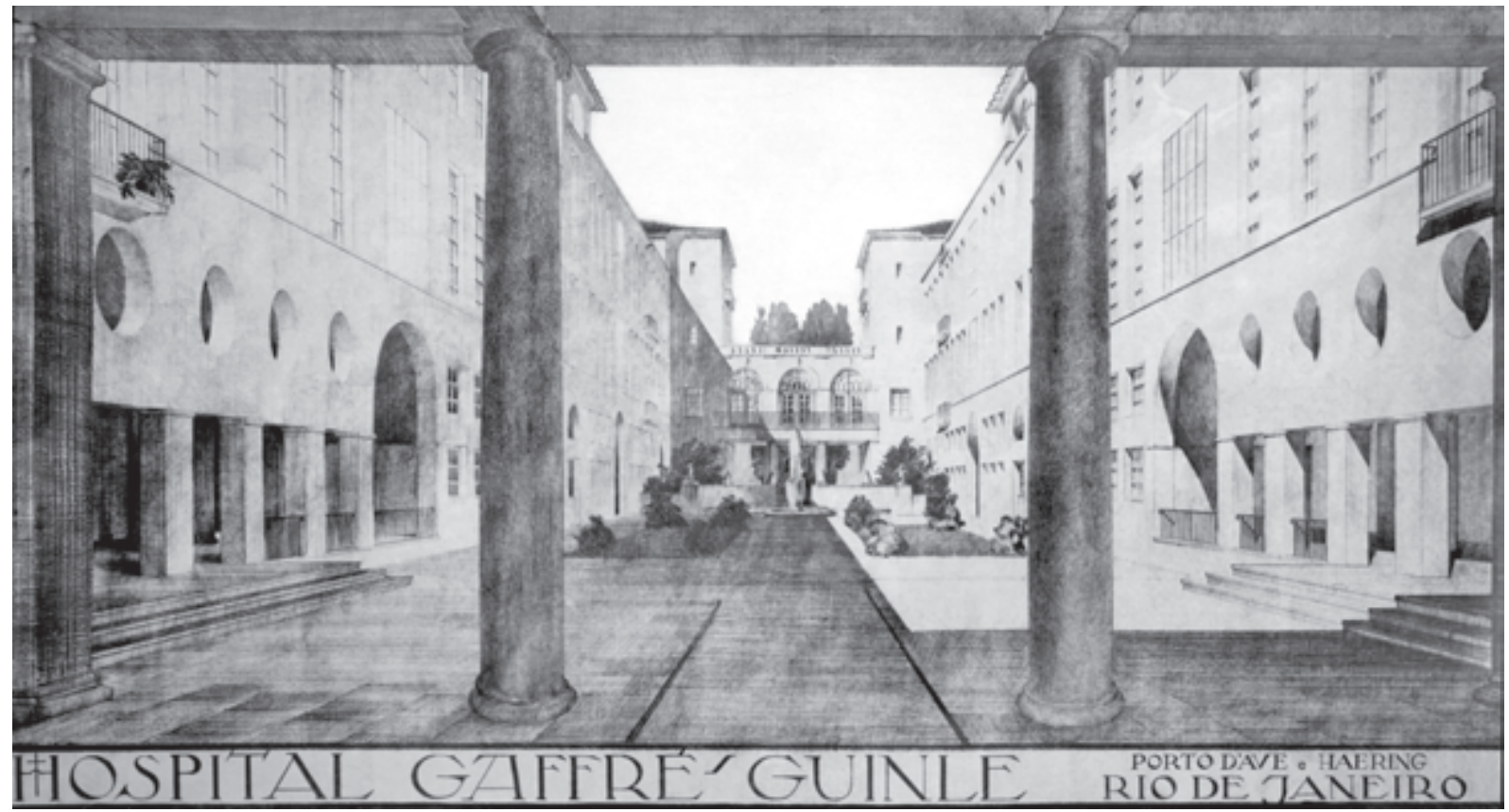

Hospital Gaffrée \& Guinle, [1924-1929]. Acervo Casa de Oswaldo Cruz

Vista do pátio interno do Hospital Gaffrée \& Guinle. Neste desenho percebe-se a utilização de elementos formais mais modernos, preteridos por um estilo mais tradicional de arquitetura, expresso na linguagem neocolonial. Projeto de Porto d'Ave e Haering.

Pavilhão de Diversões, Colônia de Curupaity, [s.d.]. Acervo Cpdoc/FGV Vista do Pavilhão de Diversões da Colônia de Curupaity, exemplar da arquitetura art déco, que neste espaço de entretenimento adota linguagem arquitetônica diferenciada em relação à dos demais edifícios propostos para o hospital-colônia. 


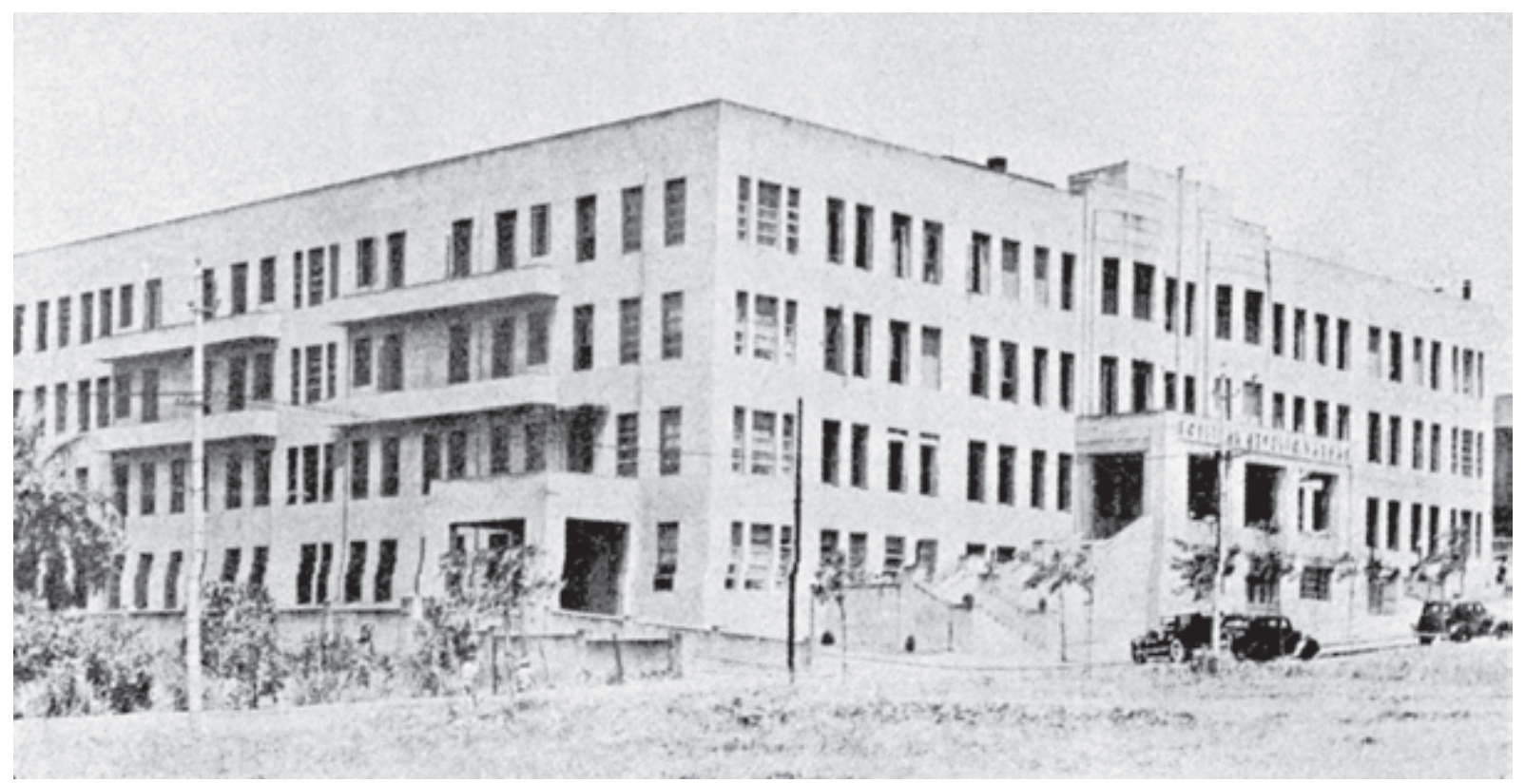

Hospital Getulio Vargas, [s.d.]. Fonte: Leonídio Ribeiro, 1956

Hospital Getulio Vargas em construção. Sua estética construtiva buscava uma aproximação com a linguagem do art déco norte-americano, uma alternativa aos padrões mais rigorosos do que seria mais tarde reconhecido como moderna arquitetura brasileira.

Hospital Santa Maria, [s.d.].

Acervo Cpdoc/FGV

Vista das varandas para tratamento da tuberculose óssea pela helioterapia, do Sanatório Santa Maria.

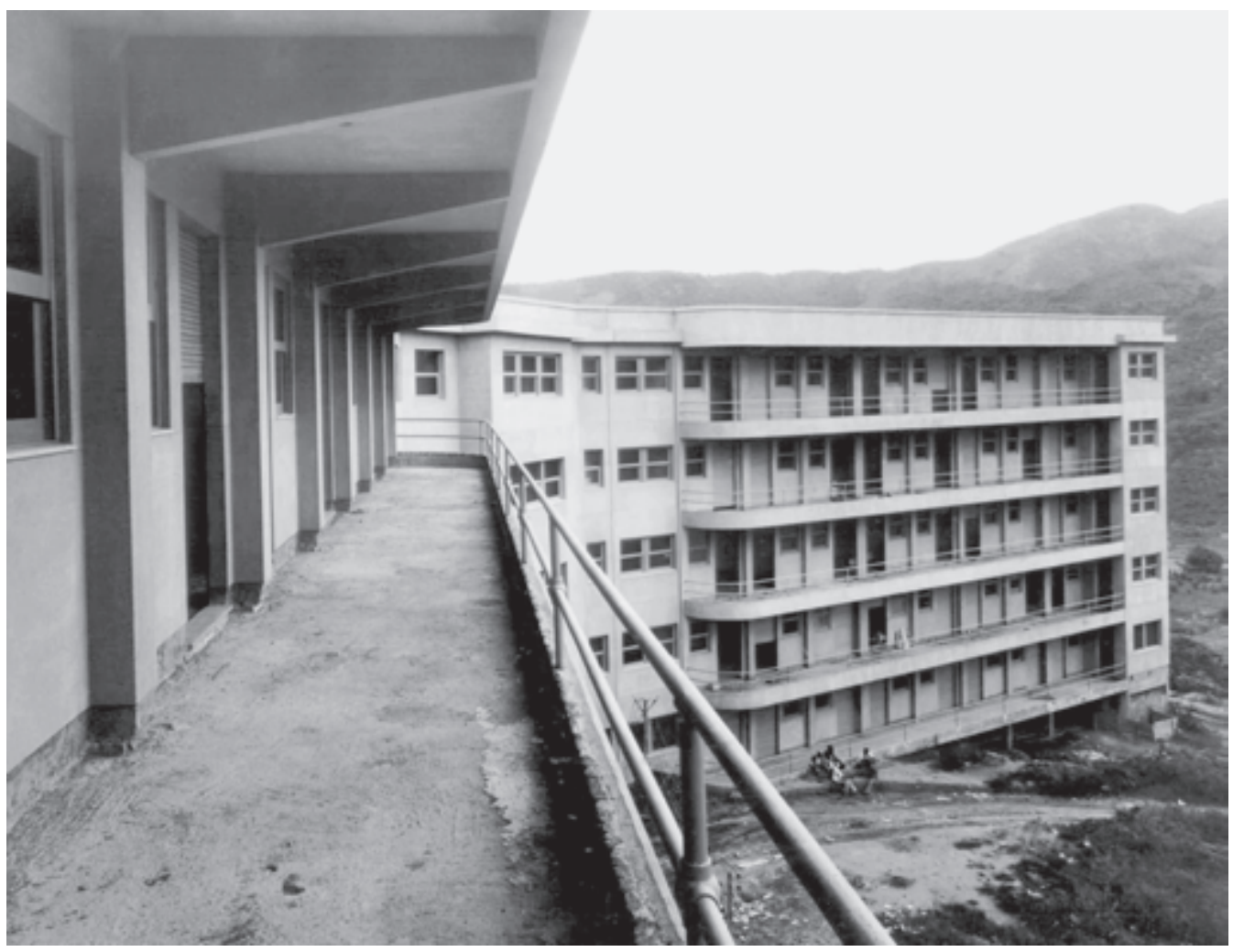




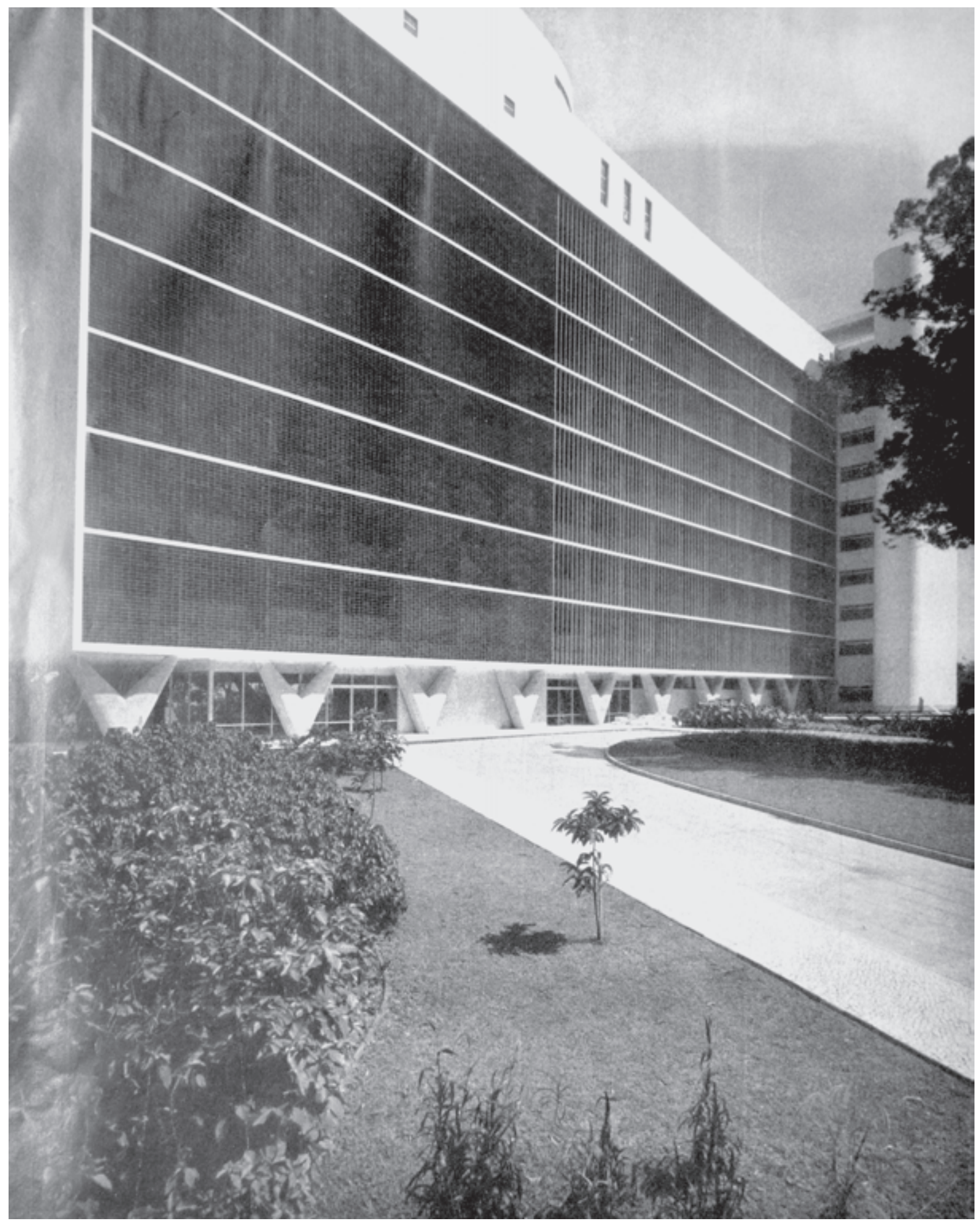

Hospital da Lagoa, [s.d.]. Fonte: Módulo, v. III, n. 14

Fachada do Hospital da Lagoa, projeto de Oscar Niemeyer e Hélio Uchoa, construído para a Companhia SulAmérica Seguros. 


\section{Imagens Contemporâneas}




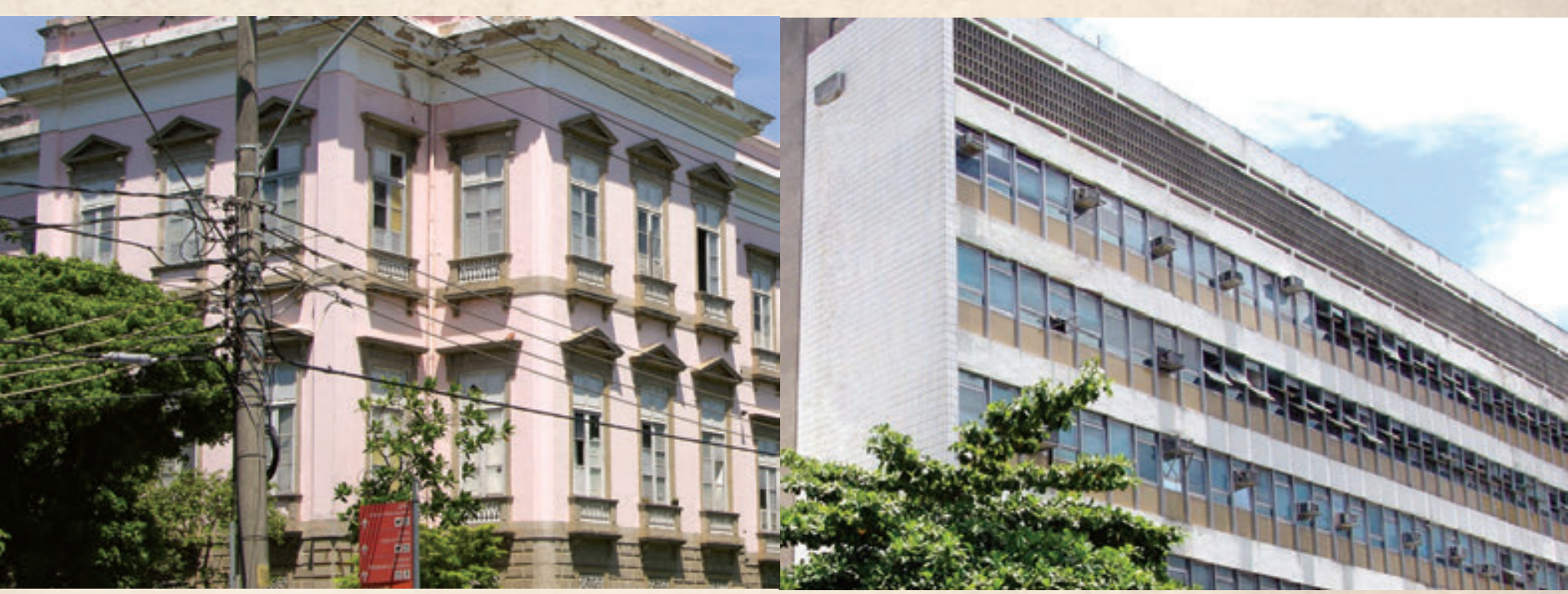



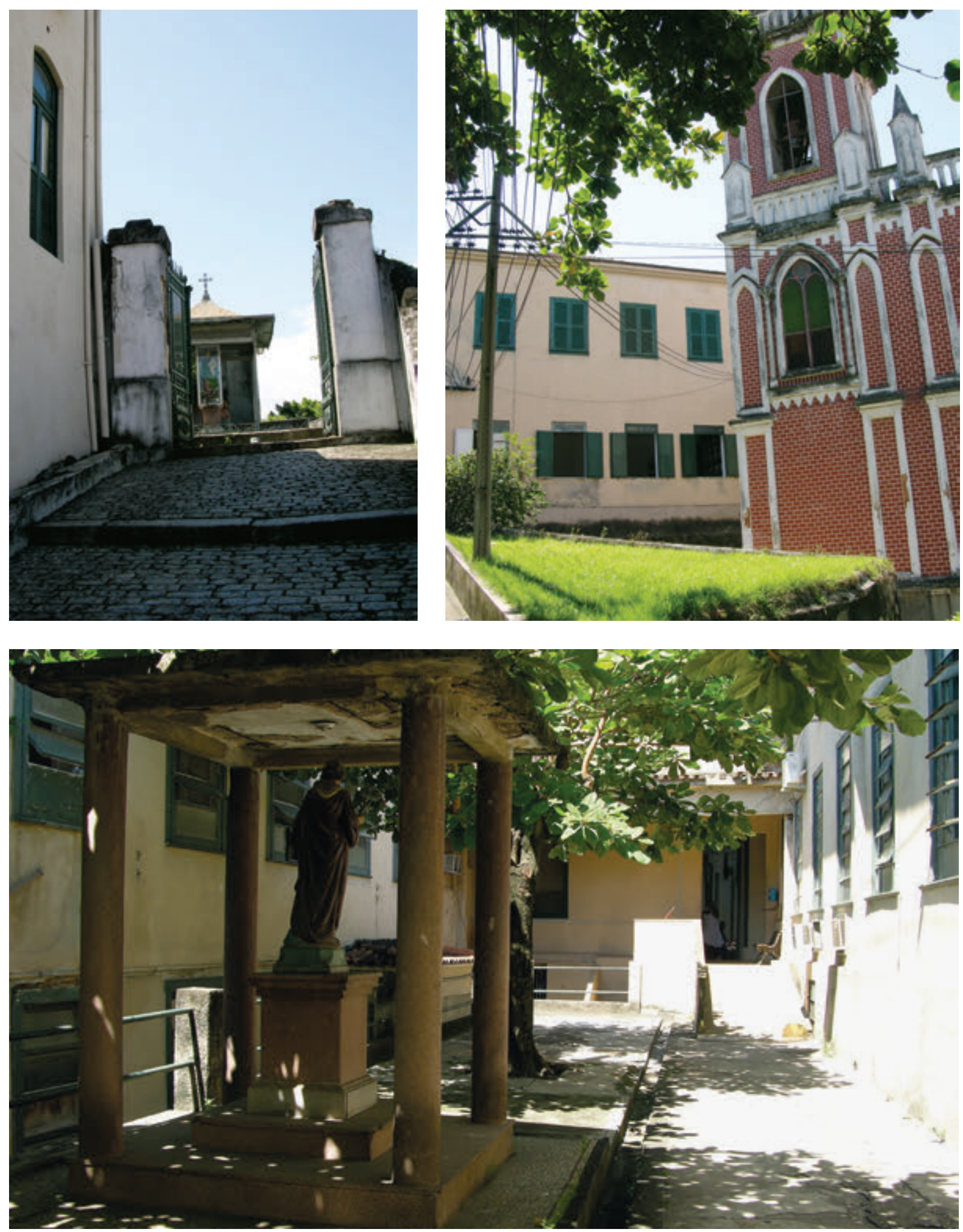

Hospital N. Sra. da Saúde, 2008. Foto Roberto Jesus Oscar e Vinícius Pequeno. Acervo Casa de Oswaldo Cruz 
HISTÓRIA DA SAÚDE NO RIO DE JANEIRO

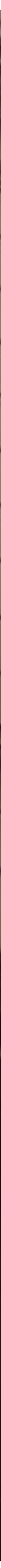

Hospital da Ordem 3a do Monte do Carmo, 2008. Foto Roberto Jesus Oscar e Vinícius Pequeno. Acervo Casa de Oswaldo Cruz 

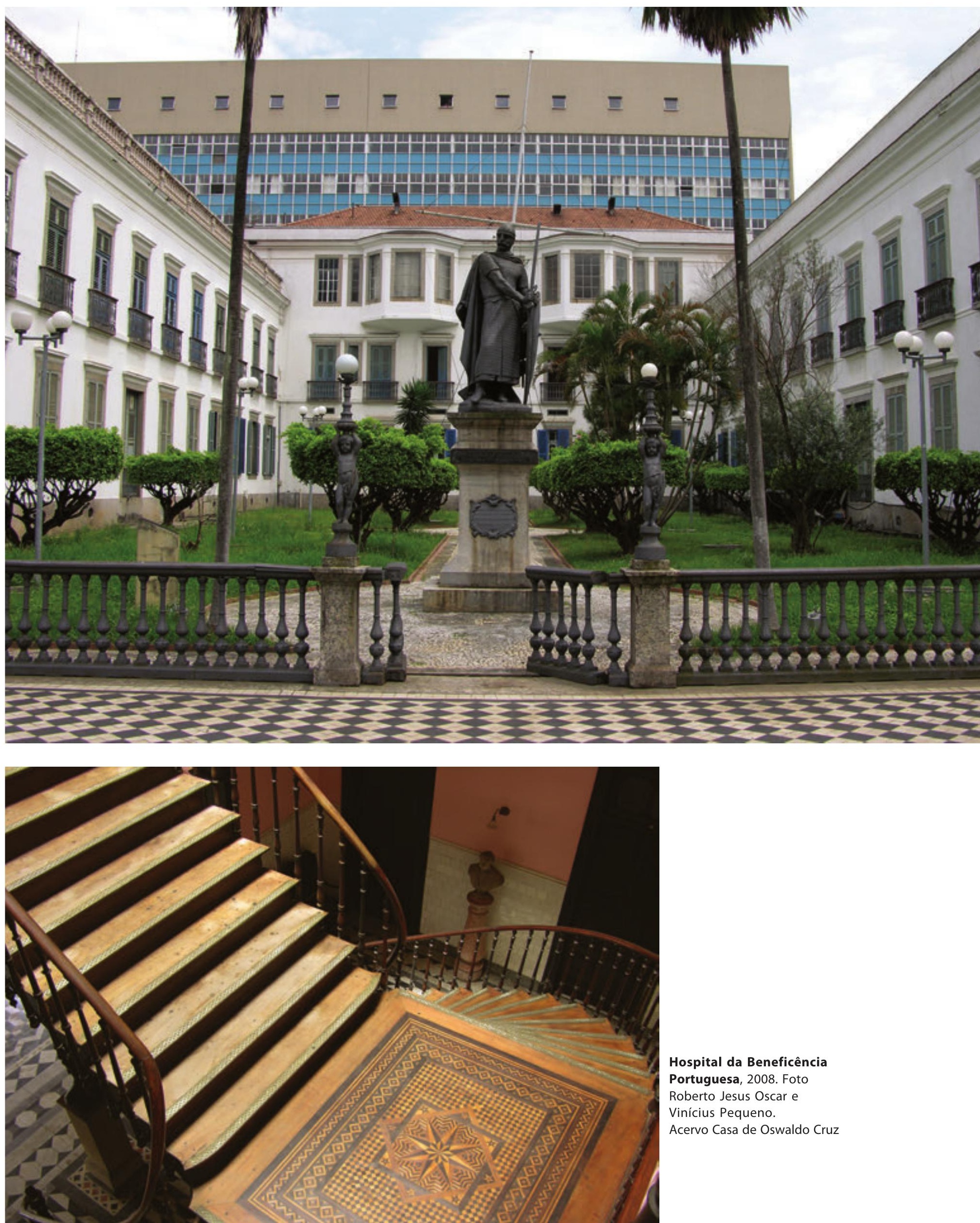

Hospital da Beneficência Portuguesa, 2008. Foto Roberto Jesus Oscar e Vinícius Pequeno. Acervo Casa de Oswaldo Cruz 


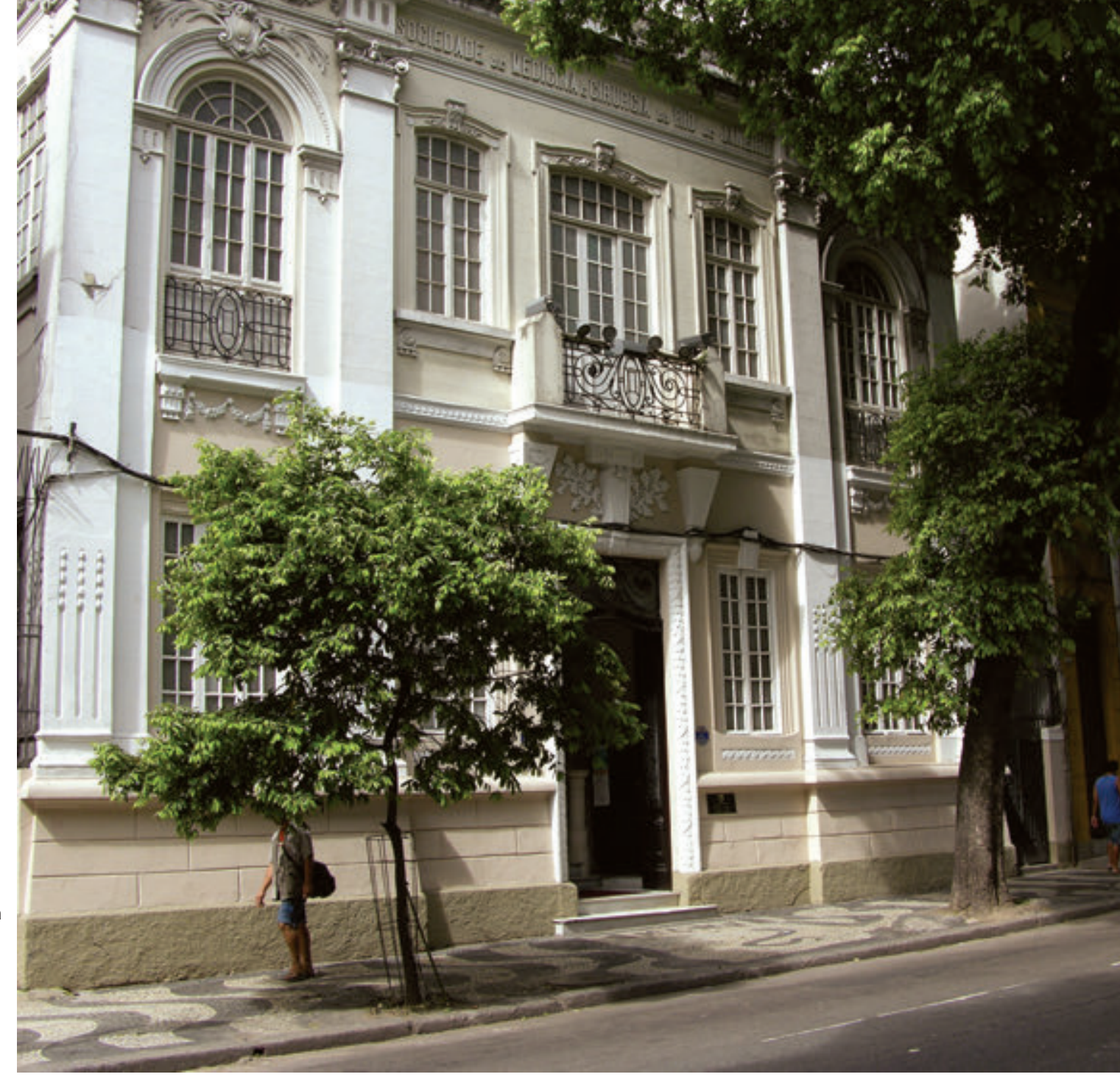

\section{Enfermaria}

Hospital Gaffrée \&

Guinle, 2003. Foto

Roberto Jesus Oscar e Vinícius Pequeno. Acervo Casa de Oswaldo Cruz

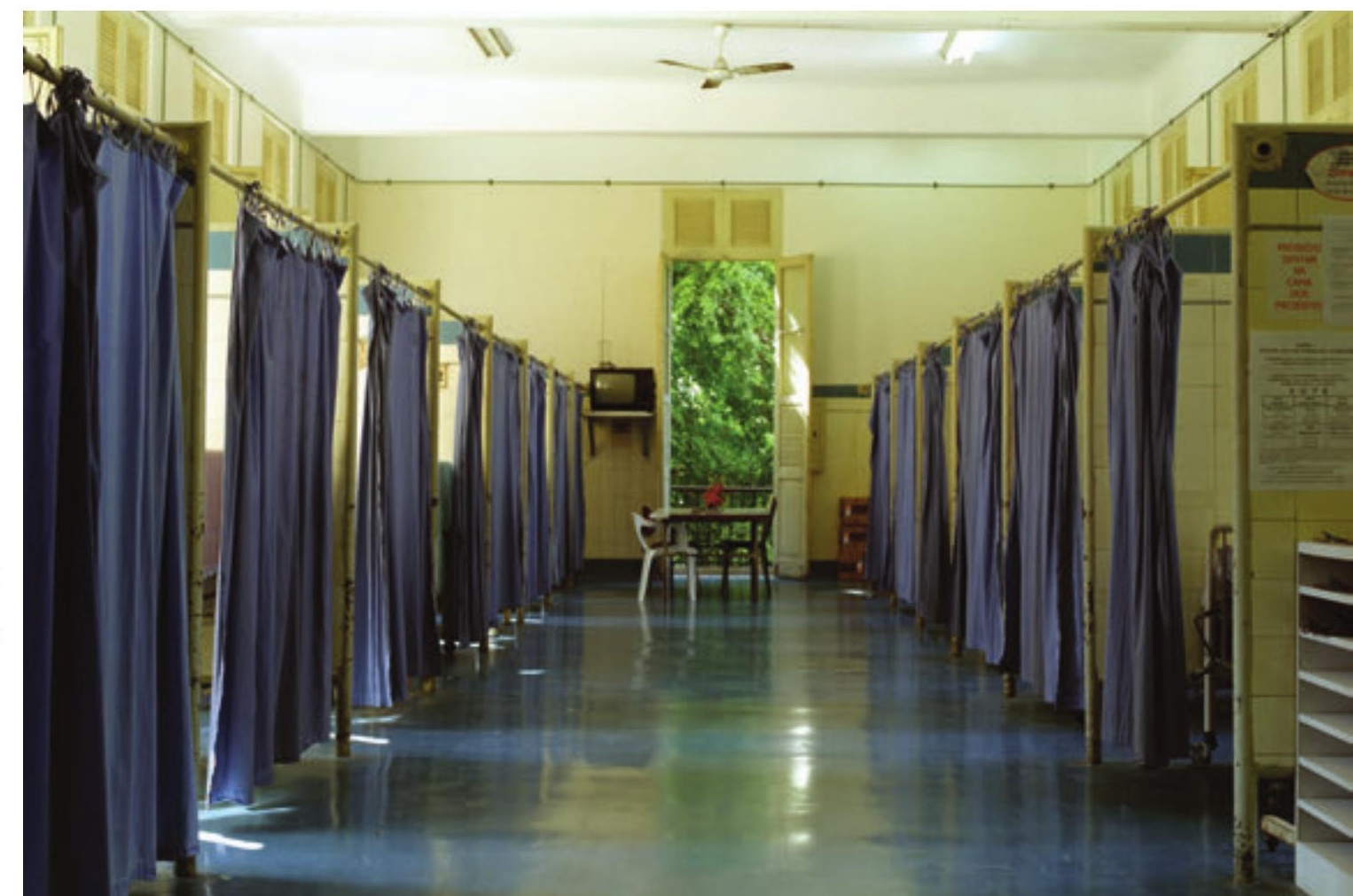



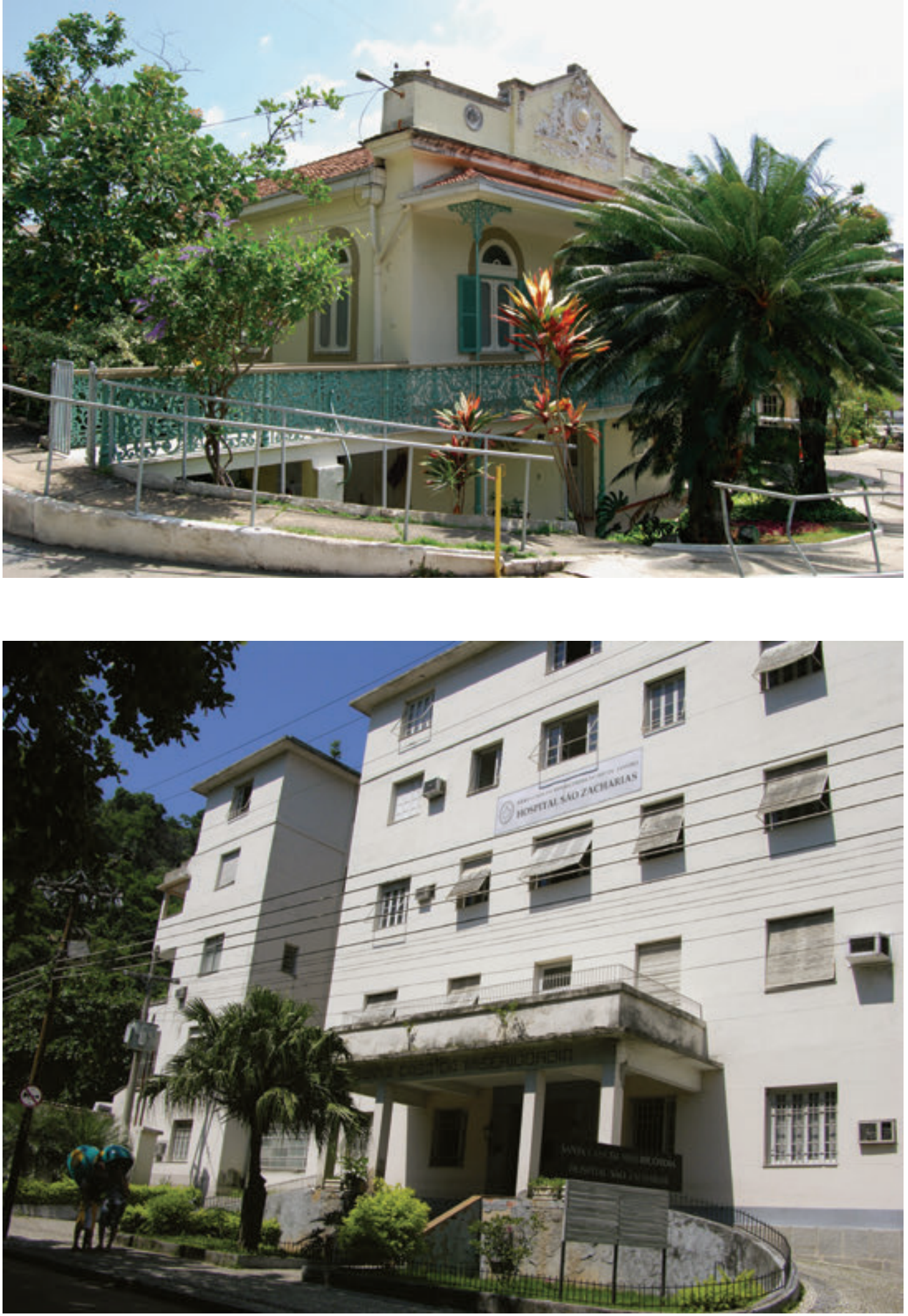

\section{Hospital do}

Amparo Feminino,

2008. Foto Roberto

Jesus Oscar e

Vinícius Pequeno.

Acervo Casa de

Oswaldo Cruz

\section{Hospital São}

Zacharias, 2008.

Foto Roberto Jesus

Oscar e Vinícius

Pequeno. Acervo Casa de Oswaldo Cruz 


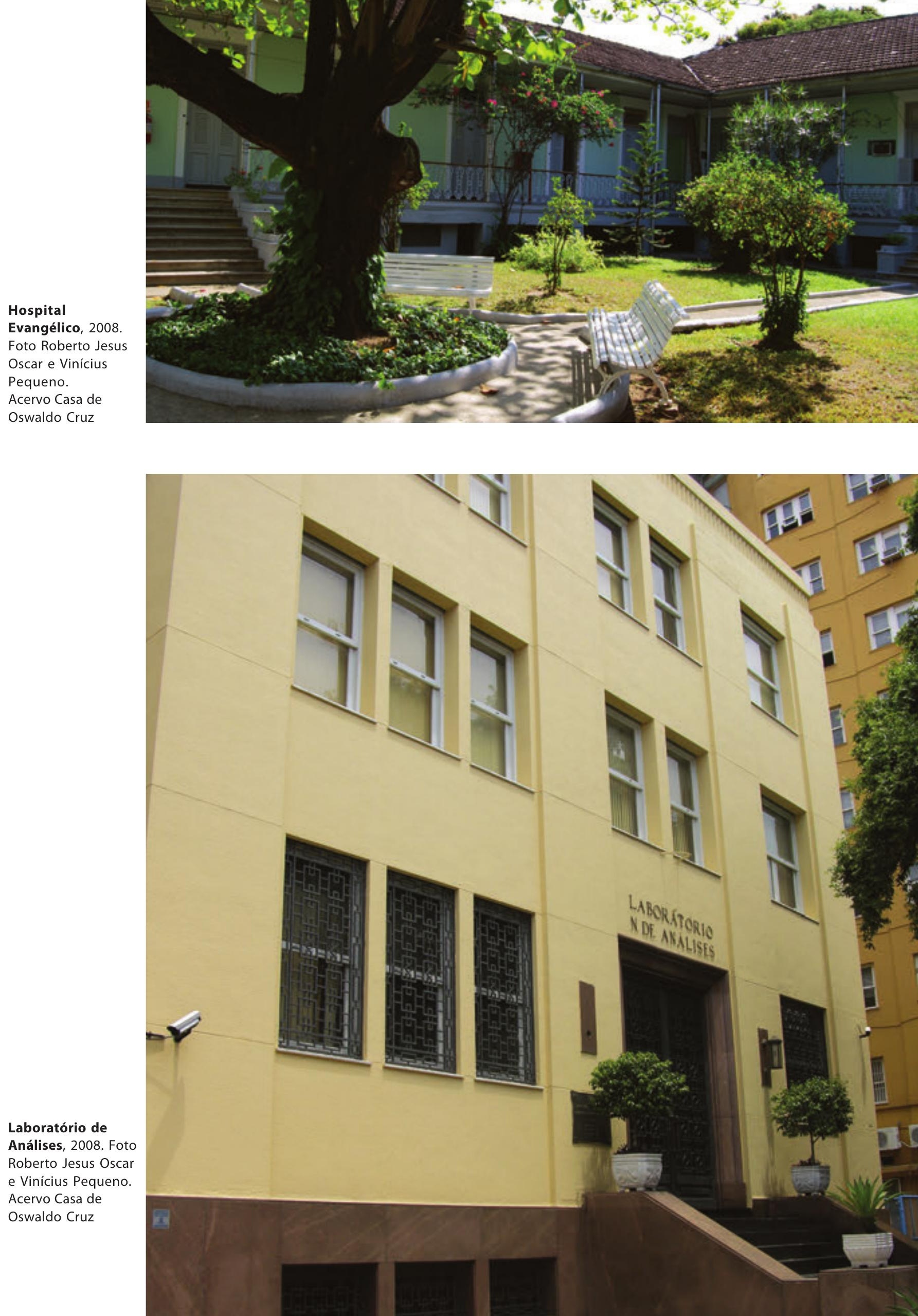



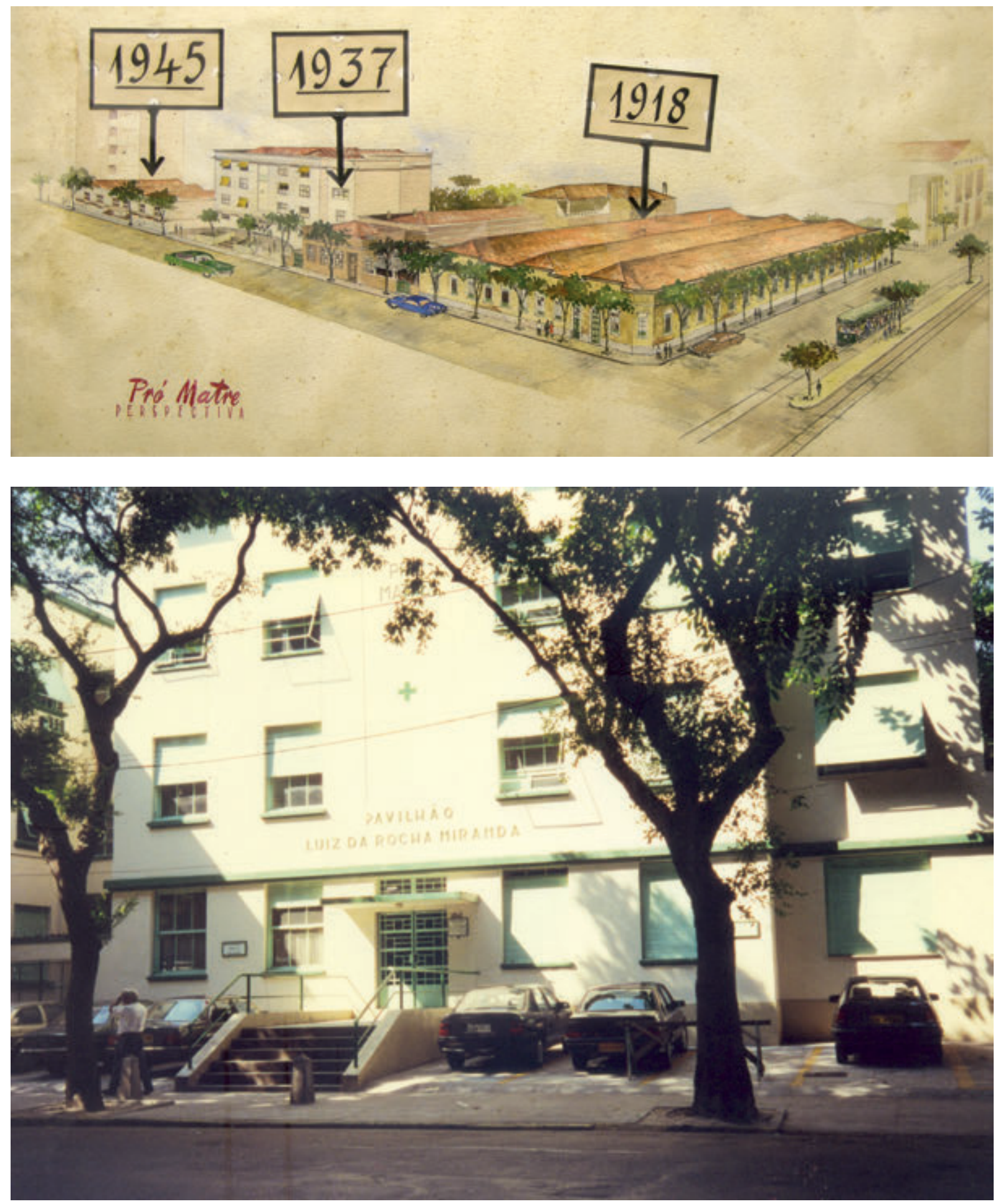

Pro Matre, [s.d.]. Acervo Pro Matre 

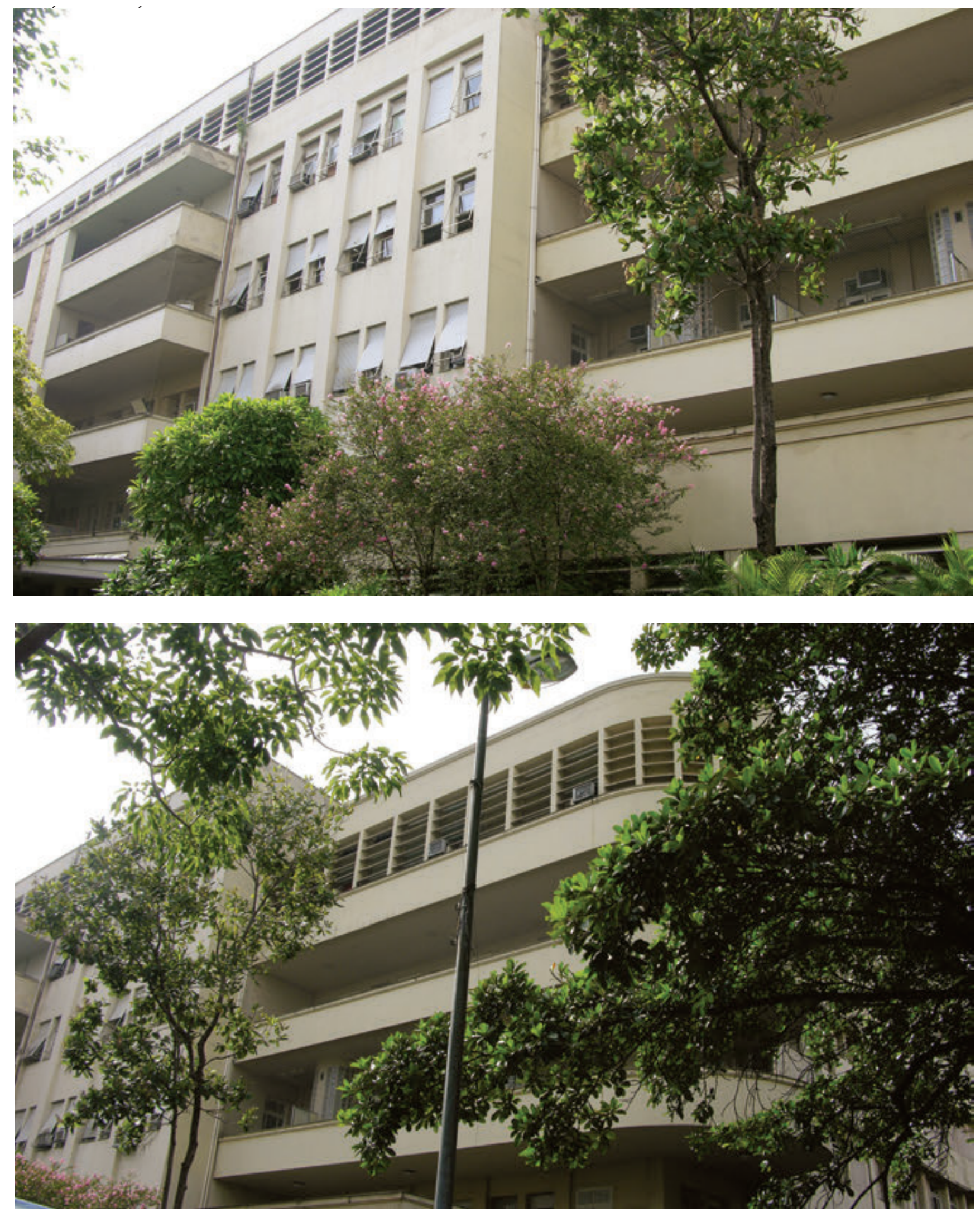

Hospital Universitário Pedro Ernesto, 2008. Foto Roberto Jesus Oscar e Vinícius Pequeno. Acervo Casa de Oswaldo Cruz 


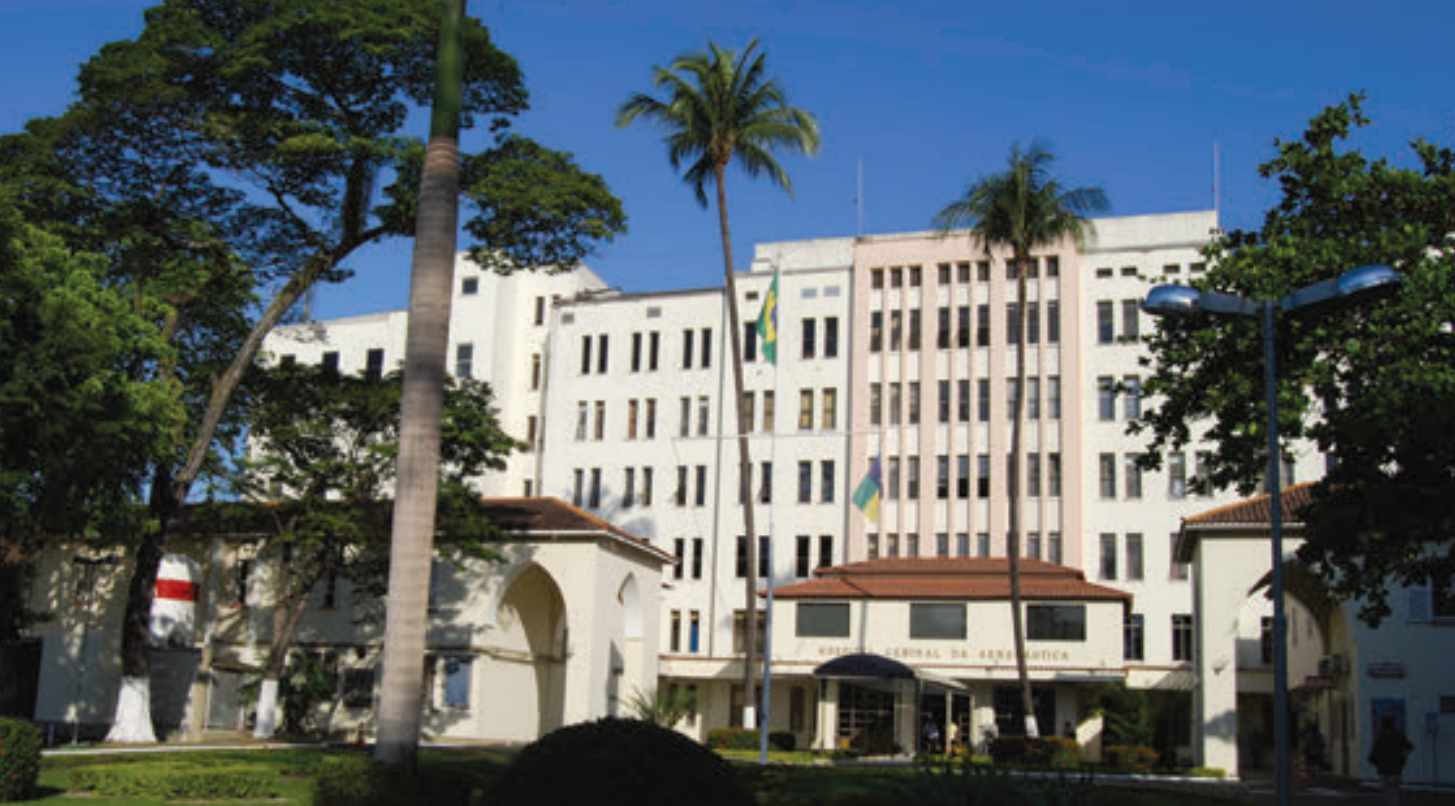

Hospital da Aeronáutica,

2008. Foto

Roberto Jesus

Oscar e Vinícius

Pequeno.

Acervo Casa de

Oswaldo Cruz

Hemorio, 2008.

Foto Roberto Jesus Oscar e Vinícius

Pequeno. Acervo Casa de Oswaldo Cruz 6.2. 5.

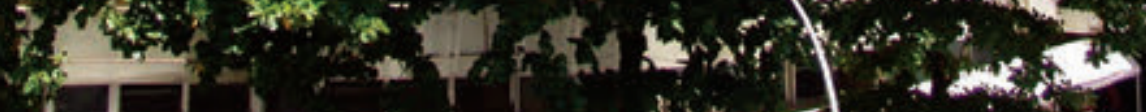

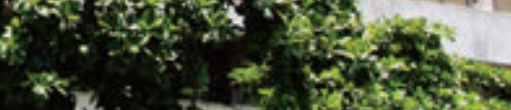

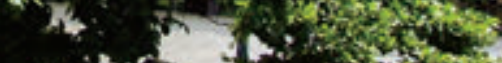

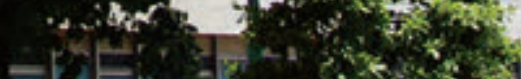

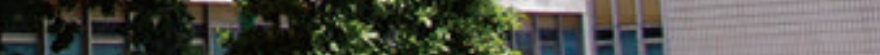

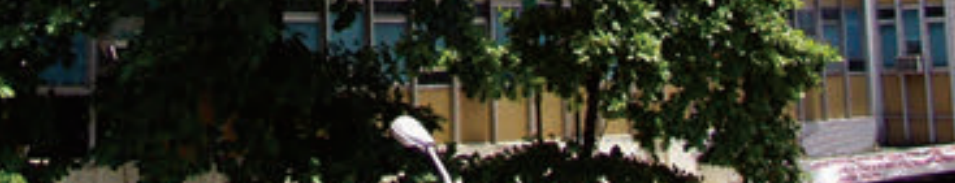
$\%$ 


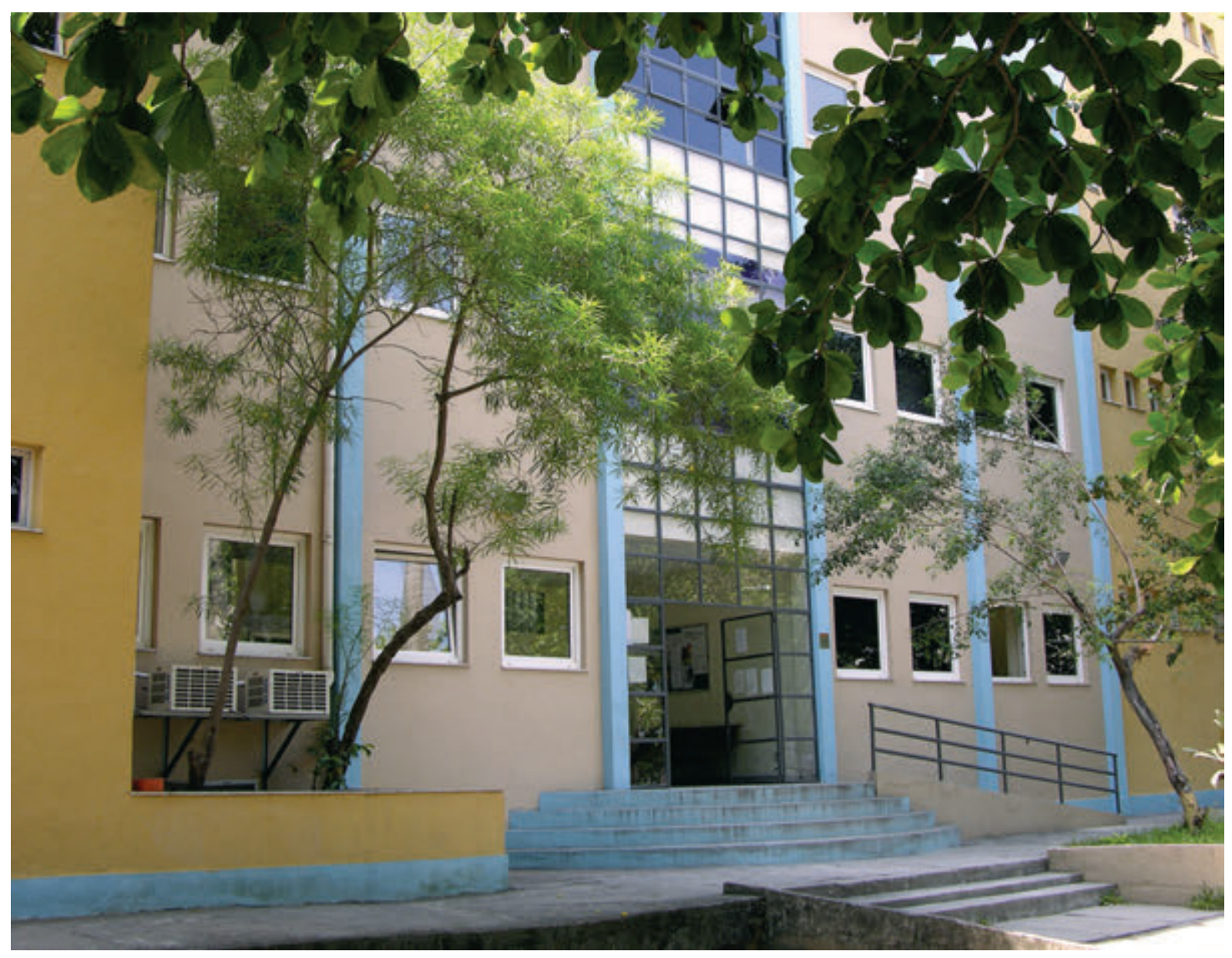

158

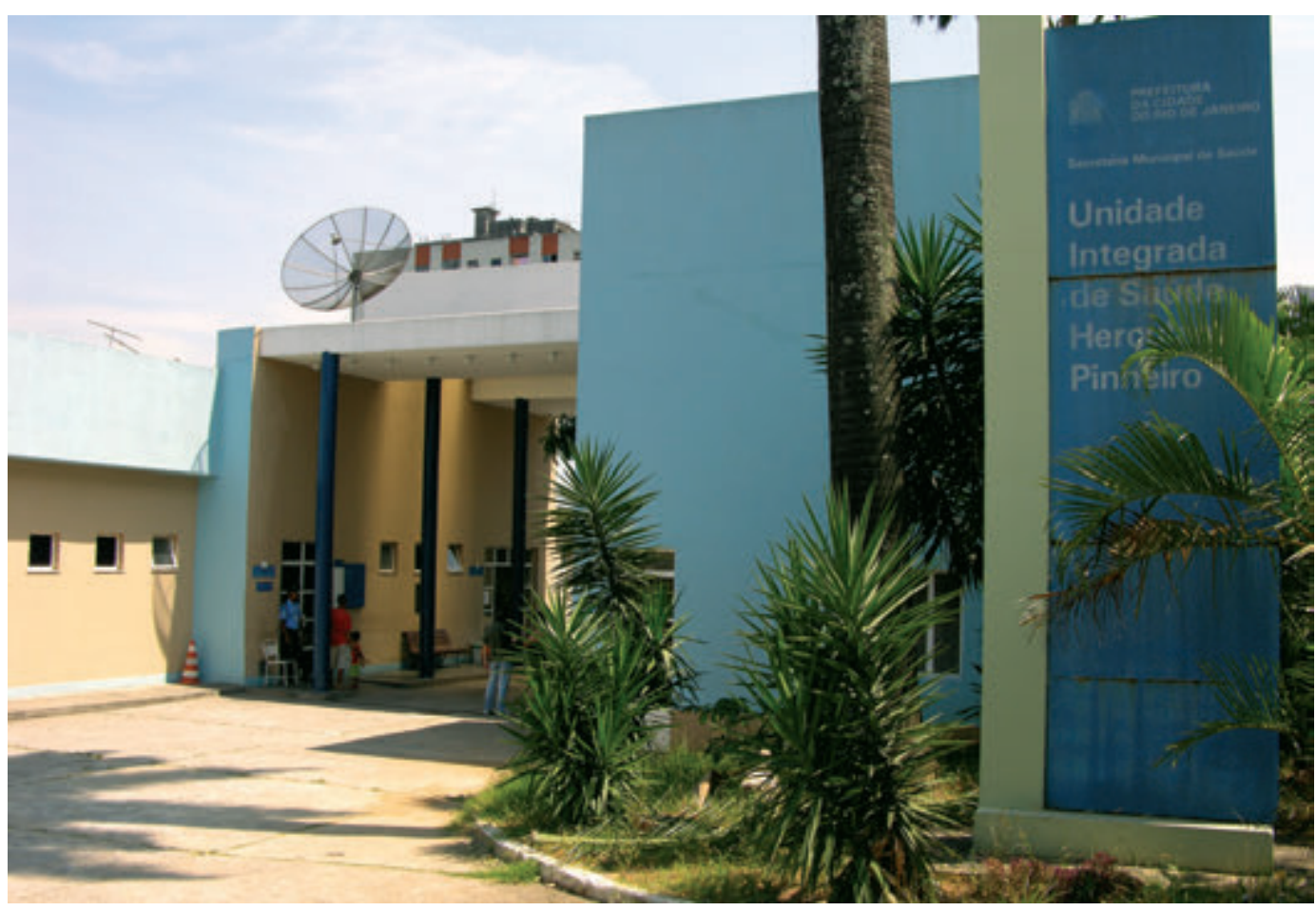

Hospital e

Maternidade

Herculano

Pinheiro, 2008.

Foto Roberto

Jesus Oscar e

Vinícius

Pequeno.

Acervo Casa de Oswaldo Cruz 


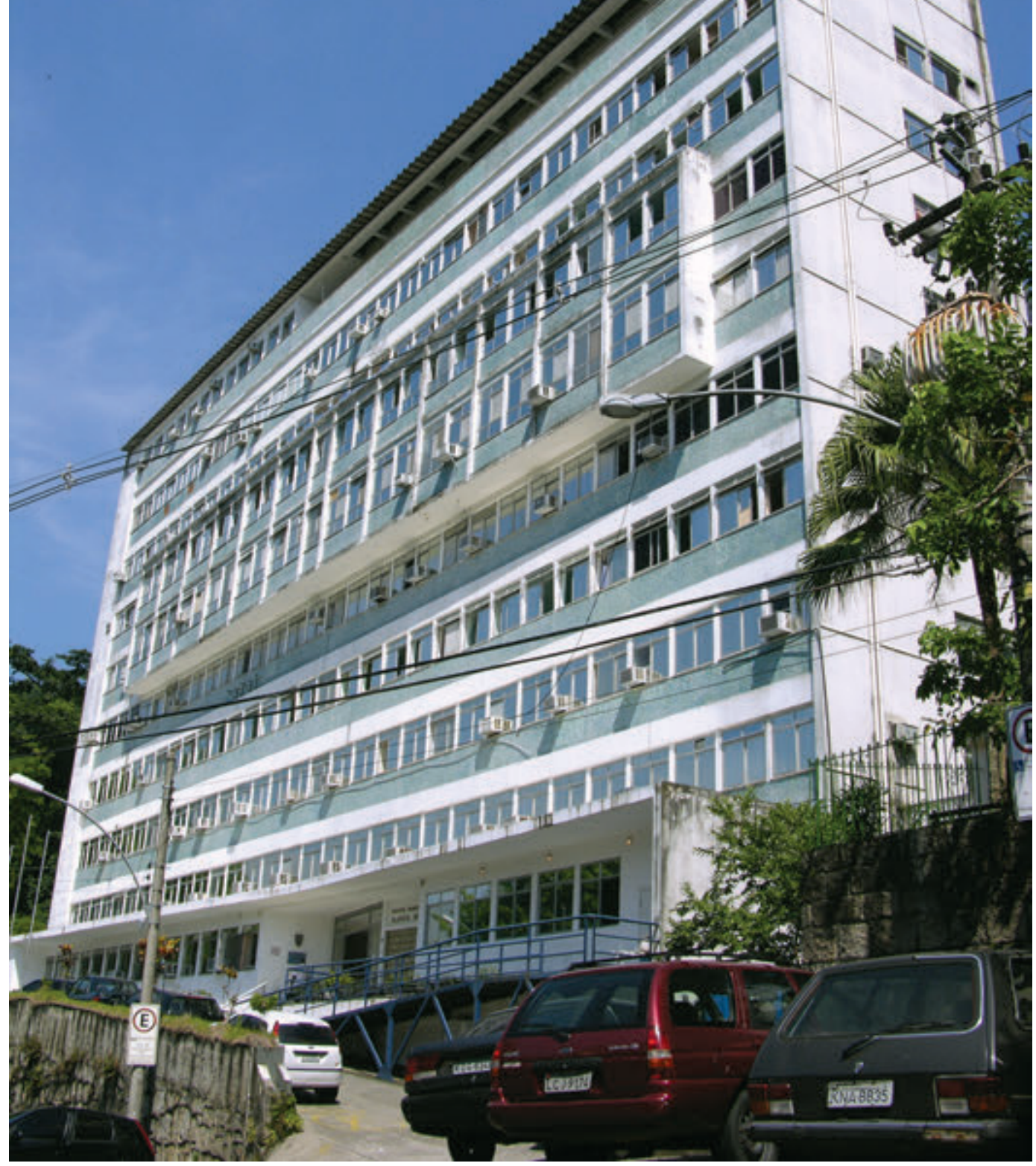

Instituto

Estadual de

Cardiologia

Aloysio de

Castro, 2008.

Foto Roberto

Jesus Oscar e

Vinícius

Pequeno.

Acervo Casa de Oswaldo Cruz

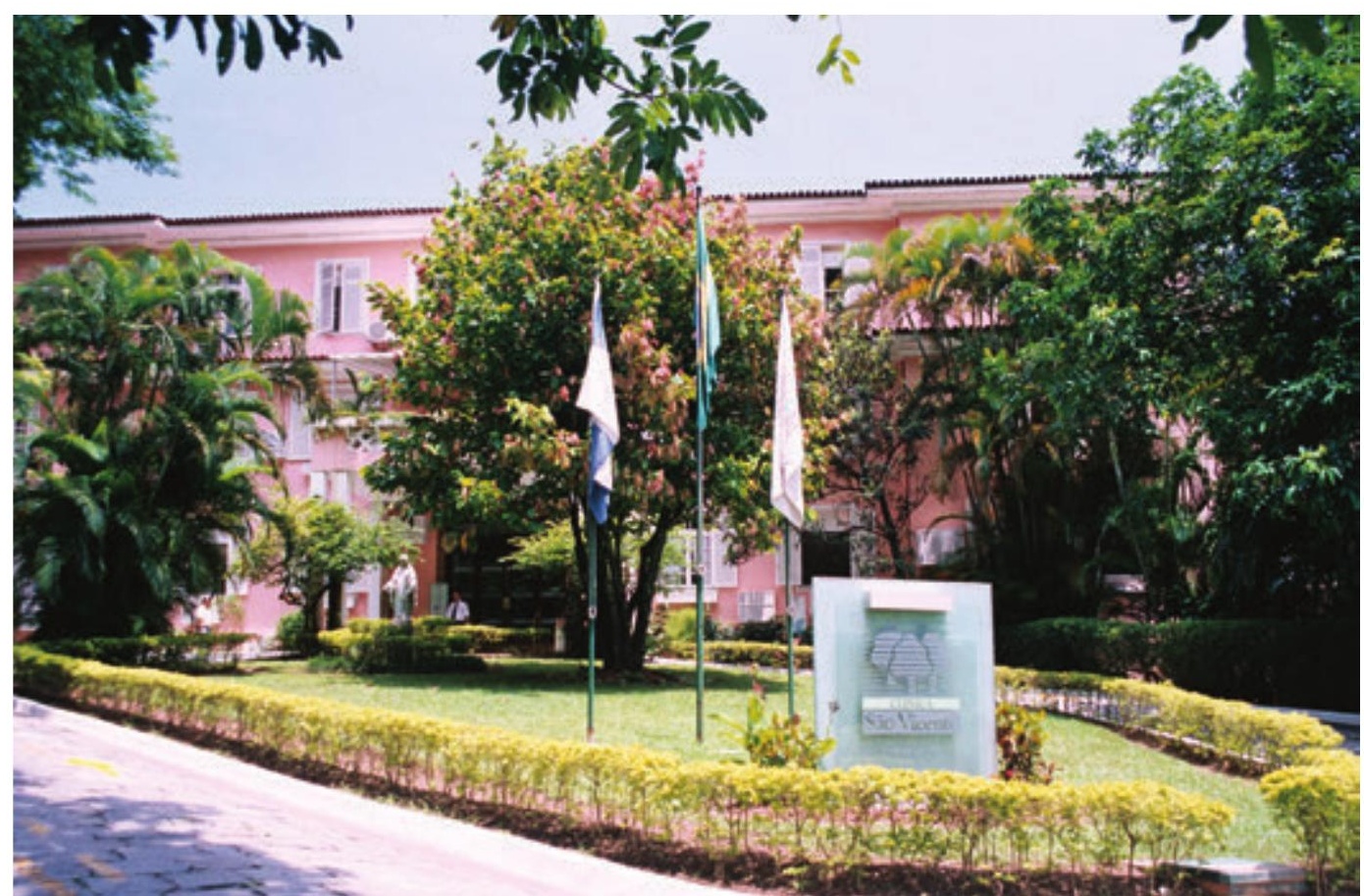

Clínica São

Vicente, [s.d.]

Acervo Clínica

São Vicente 


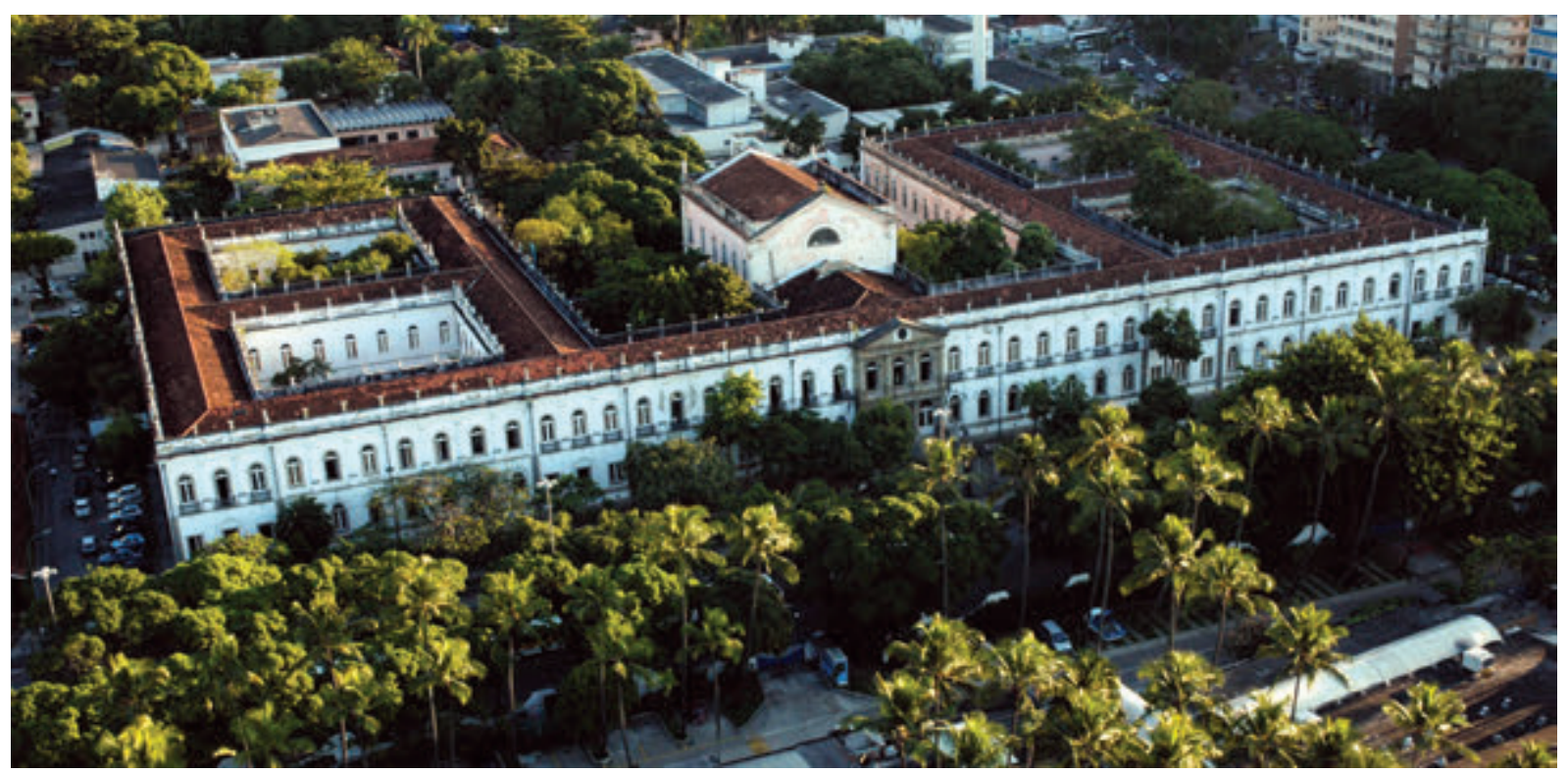

Palácio Universitário (antigo Hospício Pedro II), [s.d.]. Acervo Universidade Federal do Rio de Janeiro 


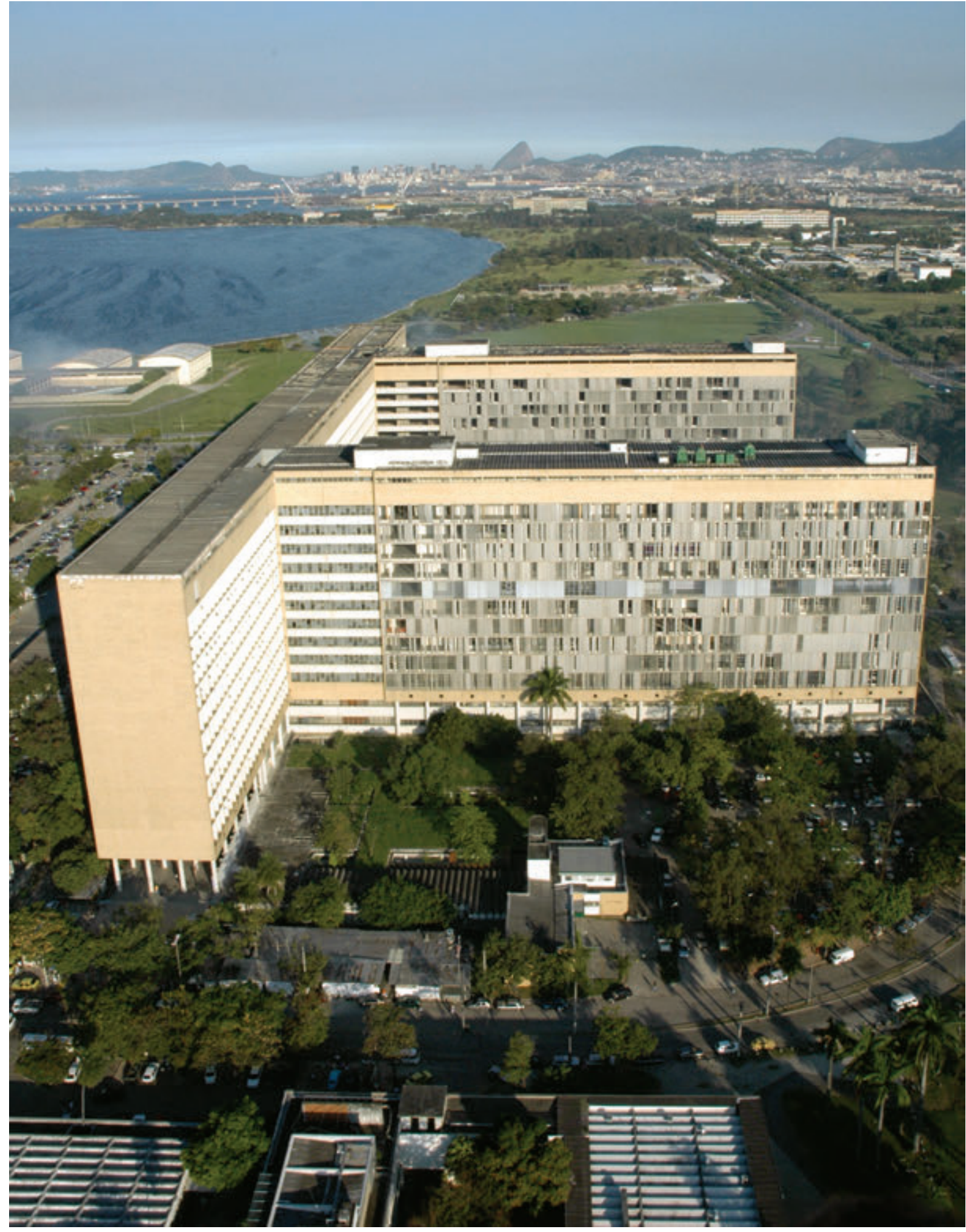

Hospital Universitário Clementino Fraga Filho, [s.d.]. Acervo Universidade Federal do Rio de Janeiro 


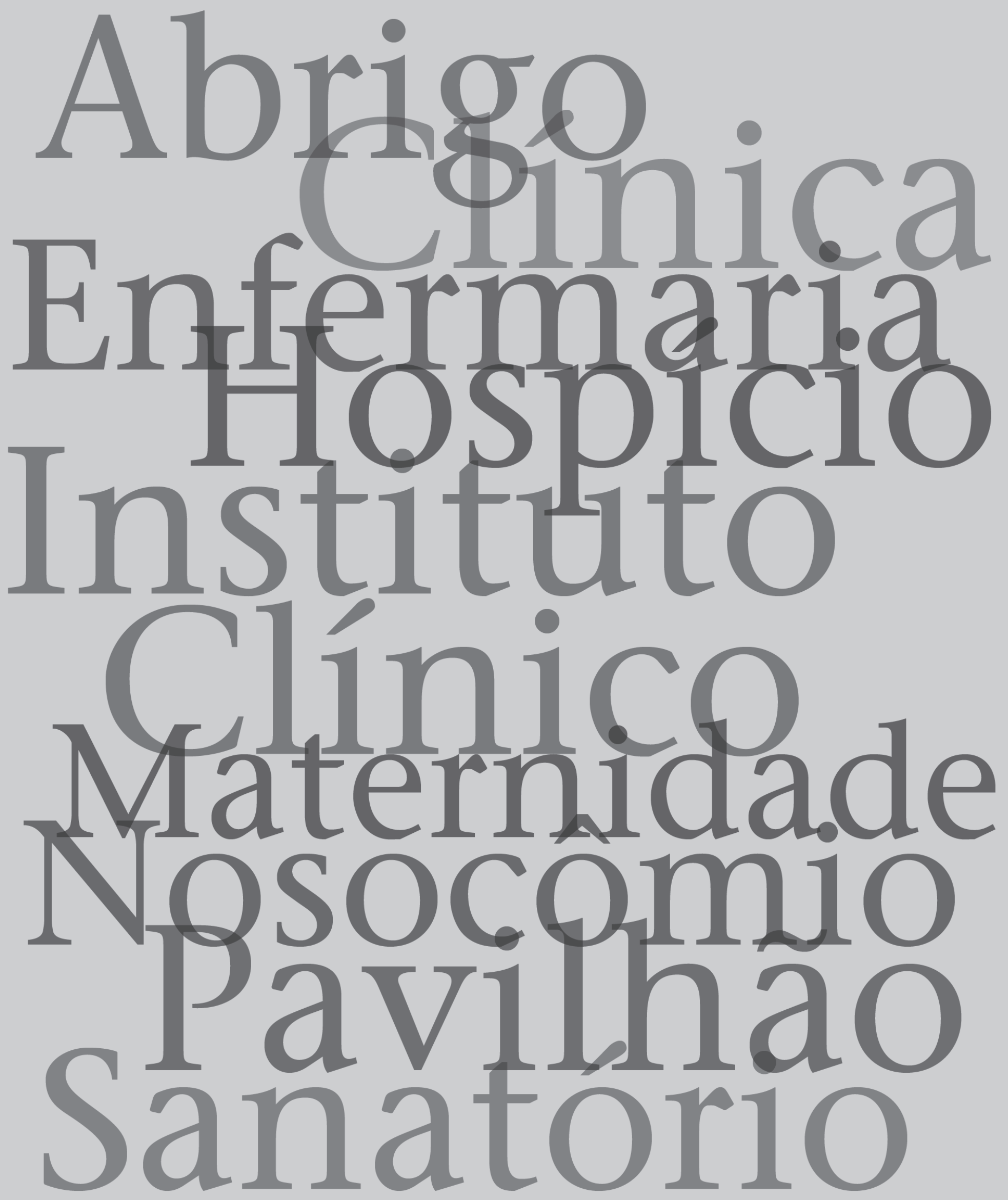




\section{Glossário}

Neste glossário o leitor encontra definições sobre instituições que fizeram e fazem parte do cotidiano da atenção à saúde.

abrigo: instituição para-hospitalar destinada à internação de pacientes por curto prazo.

albergue: instituição para-hospitalar destinada à internação de pacientes por 24 horas.

ambulatório: local onde se presta assistência em regime de não-internação. É um serviço destinado a diagnóstico ou tratamento de pacientes sem internação.

asilo: estabelecimento de assistência social, geralmente mantido por instituições filantrópicas, destinado a amparar pessoas necessitadas, idosos ou inválidos, que não têm onde morar e não são amparados por outrem, dando-lhes moradia, alimentação e cuidados higiênicos e de saúde.

assistência domiciliar: modalidade de atuação realizada por um ou mais integrantes da equipe de saúde no domicílio do paciente.

assistência de enfermagem: modalidade de atuação realizada por um ou mais integrantes da equipe de enfermagem na promoção e proteção da saúde e na recuperação e reabilitação de doentes.

assistência hospitalar: modalidade de assistência realizada por um ou mais integrantes da equipe de saúde a pacientes em regime de internação. É exercida nos hospitais gerais, impropriamente também denominados policlínicos, e nos hospitais especializados, atendendo tanto os doentes internos como os doentes externos ou de ambulatórios. É toda assistência médico-social que tem por base o hospital, qualquer que seja sua especialização ou denominação. Nesta modalidade, os cuidados médicos predominam sobre a assistência social.

assistência médica: modalidade de assistência realizada por médico na promoção e prevenção da saúde e na recuperação e reabilitação de doentes.

assistência médico-social: modalidade de assistência social em que a assistência médica constitui o aspecto predominante. Compreende as instituições hospitalares e para-hospitalares. Inclui todas as instituições que promovem ou mantêm os cuidados médicos e sociais, que tanto podem ser profissionais ou técnicos como de auxílio e amparo. Não possui a conotação de obra de caridade oficial.

assistência para-hospitalar: conjunto de ações realizadas por instituições de finalidades semelhantes às dos hospitais ou complementares à assistência hospitalar, tais como clínicas ou policlínicas, enfermarias 
isoladas, dispensários, ambulatórios isolados, estâncias de cura (hidrominerais, balneárias, climáticas), asilos, abrigos e albergues. Constitui o domínio propriamente do serviço social.

autoridade sanitária: autoridade competente no âmbito da área da saúde com poderes legais para estabelecer regulamentos e executar licenciamento (habilitação) e fiscalização.

casa de repouso: instituição destinada à recuperação de pacientes com estafa física ou mental, sem lesão orgânica.

casa de saúde: hospital geral ou especializado de finalidade lucrativa.

clínica: instituição ou serviço hospitalar destinado a diagnóstico e tratamento de doentes de uma só especialidade.

clínica de convalescença: instituição para onde são transferidos os doentes que demandam menor soma de cuidados médicos ou de enfermagem.

colônia agrícola: estabelecimento campestre onde certos condenados cumprem pena, ocupando-se de um trabalho agrícola. Também designa local onde se oferece tratamento para doentes mentais.

desinfetório: estabelecimento hospitalar onde se praticam desinfecções de determinadas enfermidades.

dispensário: estabelecimento de beneficência onde doentes pobres recebem tratamento médico gratuito, assistência social, medicamentos e roupas.

edificação dos hospitais: de tipo pavilhonar ou de várias edificações; de tipo monobloco ou em único bloco; de tipo misto - bloco com pavilhões anexos. No sistema pavilhonar os diferentes prédios têm comunicação por galerias ou pisos cobertos, ou por corredores subterrâneos, que não prejudicam o ajardinamento e a estética da superfície. O hospital de tipo monobloco, como o nome já diz, apresenta um único bloco de construção.

enfermaria: 1. o estabelecimento que disponibiliza menos de 25 leitos para a assistência médica. 2. salas contendo acomodações para quatro, cinco ou mais doentes. No hospital geral as enfermarias devem ter no máximo oito leitos. É um compartimento do hospital destinado ao alojamento de três ou mais pacientes.

especialidades médicas básicas: são quatro - clínica médica, clínica cirúrgica, clínica gineco-obstétrica e clínica pediátrica.

especialidades médicas críticas (estratégicas): especialidades médicas que em área geográfica determinada assumem maior importância devido à prevalência de patologias específicas ou à dificuldade de acesso a um estabelecimento de maior categoria.

hospício: casa onde se hospedam e tratam gratuitamente pessoas pobres ou doentes; hospital. É também um hospital utilizado para tratamento ou hospedagem de pessoas doentes ou com transtornos mentais.

hospitais de cirurgia: compreendem os estabelecimentos especializados em traumatologia e ortopedia, otorrinolaringologia, oftalmologia, ginecologia, câncer, acidentes de trabalho e outras especialidades cirúrgicas. 
hospitais de medicina: compreendem os estabelecimentos especializados em doenças mentais e nervosas, cardíacas, tuberculose, lepra (e outras doenças transmissíveis), doenças venéreas, isolamento, clínica médica, pediatria e outras especialidades médicas.

hospital: estabelecimento de saúde destinado a prestar à população assistência sanitária em regime de internação, podendo dispor de assistência ambulatorial ou de outros serviços. Os hospitais são categorizados segundo seu porte como: de tipo pequeno (25 a 49 leitos), de tipo médio (50 a 149 leitos), de tipo grande (150 a 500 leitos) e de tipo extra ou especial (mais de 500 leitos). Realiza internação de pacientes para diagnósticos e tratamentos médicos, incumbindo-lhe, ainda, atender aqueles não necessitados de internação. Também promove a recuperação social dos pacientes, além da educação sanitária da população, formação e aperfeiçoamento do pessoal hospitalar, inquéritos e pesquisas.

hospital de base: destina-se a executar atividades médico-sanitárias e constitui o centro de coordenação e integração do serviço médico hospitalar de uma zona, devendo estar capacitado para prestar, também, assistência especializada mais diferenciada, bem como para formar e aperfeiçoar pessoal hospitalar.

hospital distrital ou regional: tem atividades de saúde pública e presta assistência médica de maior amplitude, mantendo articulação com os hospitais unidades sanitárias e hospitais locais.

hospital de ensino ou hospital-escola: ver Hospital Universitário.

hospital especializado: instituição monovalente destinada a prestar assistência à saúde em uma especialidade ou especialidades correlatas. Divide-se em diferentes tipos: maternidades e berçários; hospitais de medicina; hospitais de cirurgia; hospitais de crônicos e incuráveis; hospitais de convalescença. Ex.: para tuberculosos, cardíacos, venéreos etc.

hospital geral: hospital polivalente destinado a prestar assistência à saúde nas seguintes especialidades: clínica médica, pediatria, gineco-obstetrícia, cirurgia e outras. Recebe doentes de todas ou de várias espécies de enfermidades. São exemplos típicos as santas casas da Misericórdia e certos hospitais de assistência pública e pronto-socorro. Atende pacientes necessitados de recursos clínicos gerais ou especializados. Classifica-se em: hospital unidade sanitária, hospital local ou comunidade, hospital regional ou distrital, hospital de base, hospital de ensino médio.

hospital local ou de comunidade: é aquele que, em seu programa de atividades de assistência médica, clínica, cirúrgica, obstétrica e pediátrica, integra as de saúde pública, de acordo com suas possibilidades de pessoal e equipamento.

hospital policlínico: estabelecimento hospitalar destinado a várias clínicas: médica, cirúrgica e outras.

hospital unidade sanitária: (unidade médico-sanitária, unidade mista, unidade integrada de saúde) é aquele que compreende em seu programa as atividades de assistência médica, inclusive hospitalização para clínica e cirurgia de urgência, obstétrica, e as de saúde pública.

hospital universitário: hospital de base utilizado para formação e aperfeiçoamento de médicos e profissionais afins. Um hospital universitário ou hospital de ensino é um centro de atendimento hospitalar mantido por universidades, normalmente utilizado como base para o aprendizado dos alunos de cursos como os de enfermagem e medicina. 
instituição filantrópica: destina a totalidade de suas rendas às atividades de assistência médico-social gratuita e mantém um terço dos leitos hospitalares, no mínimo, para atendimento gratuito do público em geral.

instituição de finalidade lucrativa: aquela que visa a auferir lucros, ou a distribuir dividendos.

instituição de finalidade não lucrativa: não visa a lucros, distribuição de dividendos ou vantagens de qualquer natureza e atende, predominantemente, uma determinada clientela (associados, segurados, irmãos de sociedades beneficentes etc.).

instituição oficial: pertencente a pessoa jurídica de direito público.

instituição para-hospitalar: em que há predominância da assistência social sobre a assistência médica.

instituição particular: pertencente a pessoa jurídica de direito privado.

instituições não oficiais ou particulares: subdividem-se em filantrópicas, de finalidade não lucrativa, de finalidade lucrativa. No primeiro grupo estão as instituições de caridade, as de assistência gratuita, as pertencentes a igrejas, irmandades, fundações e outras corporações. As de finalidade não lucrativa, semelhantes, de algum modo, às filantrópicas, são instituições mantidas por corporação, fábricas ou núcleos para seus empregados; são as de cooperativas, de associações de classe, escolas ou universidades, beneficências, caixas, ordens terceiras etc., isto é, organizações que não distribuem dividendos ou lucros e cuja renda se destina exclusivamente à finalidade médico-social, a manter, melhorar e ampliar a instituição, a bem da saúde. Entre as instituições de finalidade lucrativa se acham as casas de saúde e hospitais mantidos por médicos, por sociedades, por cotas, visando a uma exploração industrial ou comercial, de firma, sociedade anônima etc.

instituições oficiais ou governamentais: podem ser federais, estaduais e municipais e pertencem ao Exército, à Marinha, à Aeronáutica, à Polícia, ao Corpo de Bombeiros, à Saúde Pública, à Assistência Pública, a universidades oficiais etc., ou são mantidas ou dirigidas por essas organizações.

instituto clínico: instituição destinada a diagnóstico, tratamento e pesquisas.

internato: estabelecimento escolar em que os alunos não apenas estudam, mas vivem entre seus pares em alojamentos normalmente anexos ao prédio principal. O regime de internato pode incluir alojamento apenas durante os dias úteis (de segunda a sexta-feira) ou também durante o fim de semana.

maternidade: setor de um hospital destinado ao atendimento de parturientes, tanto para a assistência médica quanto para internação por ocasião do parto. Pode também ser um hospital dedicado exclusivamente a esse fim.

nosocômio: local onde se recebem e tratam doentes; o mesmo que hospital.

pavilhão: edificação isolada ou não, onde funcionam um ou mais serviços do hospital.

policlínica: hospital que oferece atendimento médico em muitas especialidades médicas.

posto de saúde: unidade de atendimento de saúde. 
preventório: estabelecimento onde se internam pessoas que estiveram expostas a algum agente causador de doença, até que se verifique se a contraíram ou não. Internato onde são criados os filhos de tuberculosos ou hansenianos, para tirá-los do meio do contágio.

pronto-socorro: hospital destinado a atendimento médico de urgência.

rede de estabelecimentos de saúde: conjunto de estabelecimentos do sistema de saúde, regionalizado e hierarquizado, por níveis de complexidade, capacitado para resolver todos os problemas de saúde da população sob sua responsabilidade.

sanatório: edifícios para onde os doentes com tuberculose, lepra ou doentes mentais eram encaminhados, ficando assim completamente excluídos da sociedade. Regra geral, situavam-se em locais altos e arejados, proporcionando um contato privilegiado com a natureza.

serviço social: conjunto de técnicos que visam à utilização dos recursos da comunidade para promover a reintegração ao meio social dos indivíduos ou grupos necessitados de assistência.

serviço social médico: serviço prestado ao doente e sua família visando à remoção dos problemas sociais que interferem no tratamento do doente e à sua reintegração na comunidade.

\section{Bibliografia}

DICIONÁRIO Barsa da Língua Portuguesa. São Paulo: Barsa Planeta, 2005.

DIVISÃO e organização hospitalar. Assistência médica e social. Arquivos de Higiene, vol. 13, 1943.

MINISTÉRIO da Saúde. Departamento Nacional de Saúde. História e Evolução dos Hospitais. 2. ed. Rio de Janeiro, 1965.

MINISTÉRIO da Saúde. Agência Nacional de Vigilância Sanitária (Anvisa). Glossário de Termos Comuns nos Serviços de Saúde do Mercosul [on-line]. Disponível em: <e-legis.anvisa.gov.br/leisref/public/ showAct.php?mode=PRINT_VERSION\&id=6>. Acesso em: 17 out. 2007.

WIKIPÉDIA. A enciclopédia livre [on-line]. Disponível em: <pt.wikipedia.org>. Acesso em: 29 jan. 2008. 
10

Hing $\quad 3=$

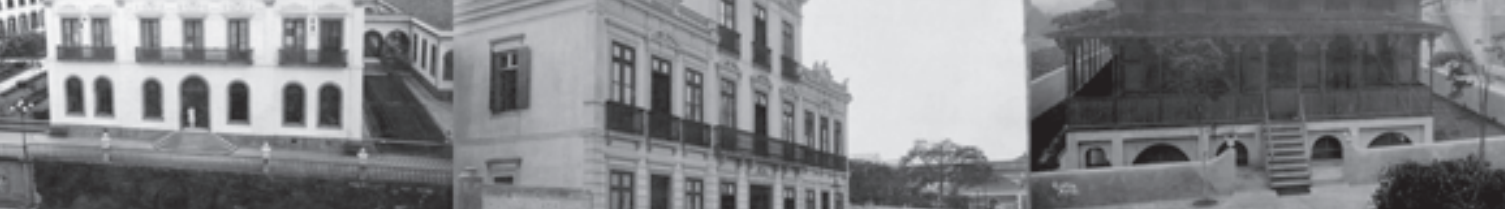

B A 2 I|⿴囗十)

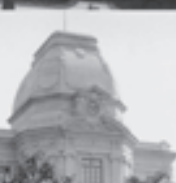

毣 $-x^{2}$

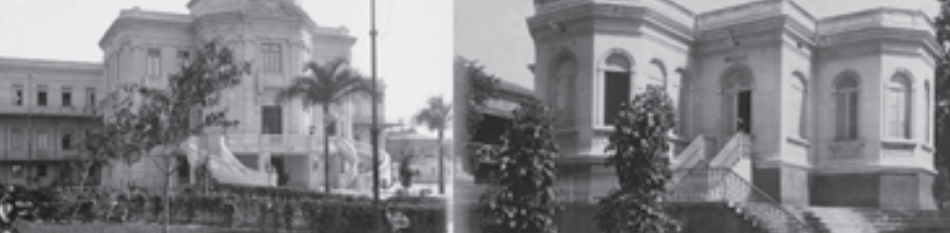

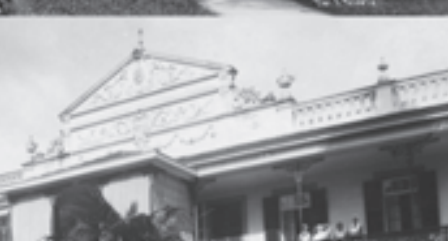

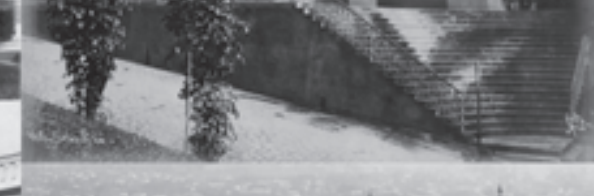

ats

\section{.}

$\operatorname{man} \rightarrow$ in:

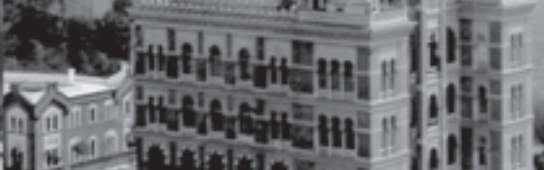
s.

แกิ Ats

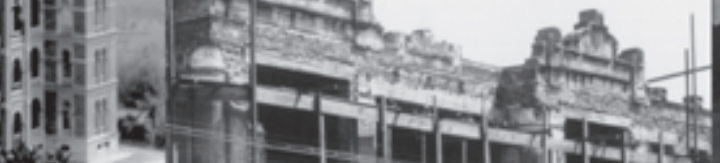

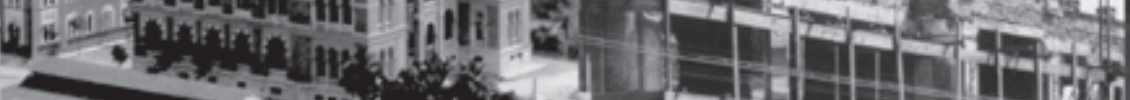

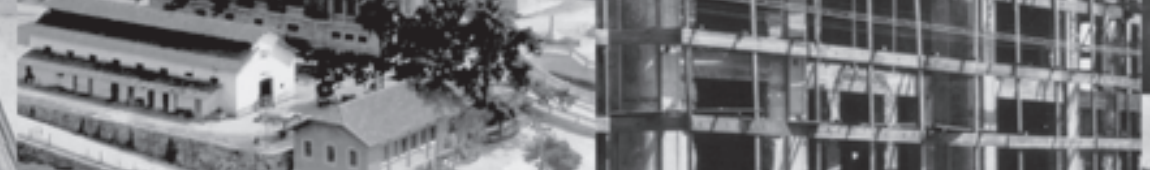
nemin.

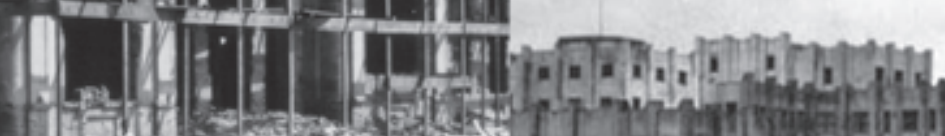
ifi 端 ivis 任

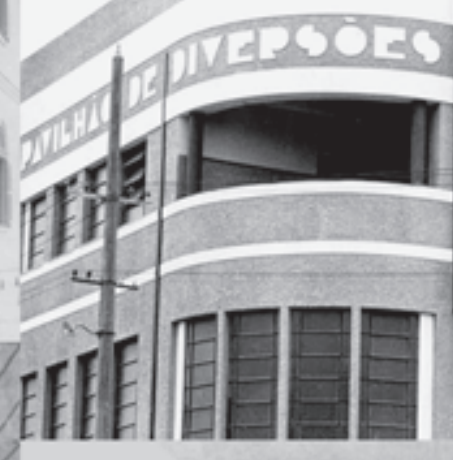

$y=$

i:

$\int_{1}$

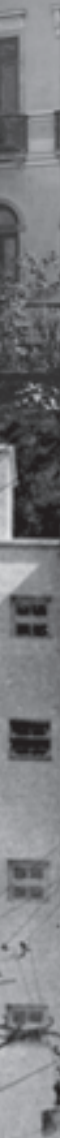
2.11:

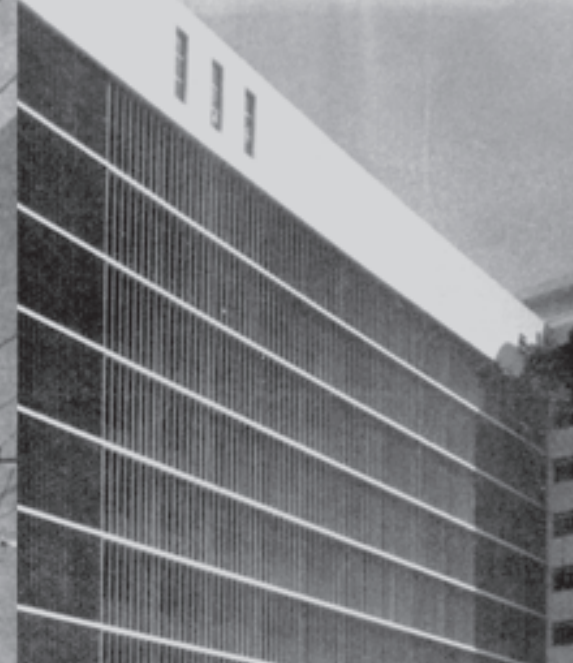

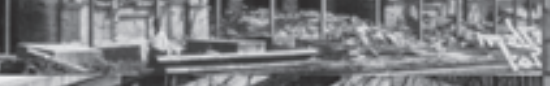

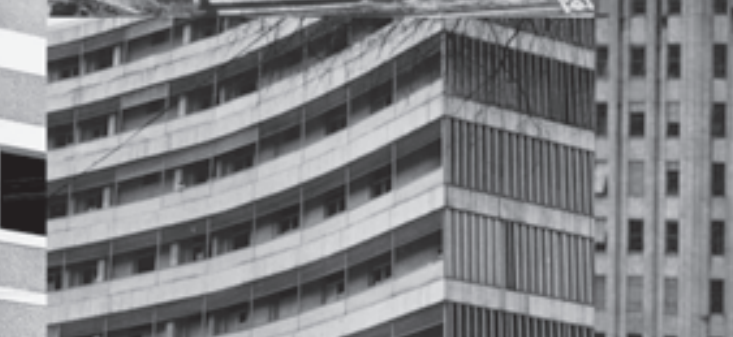

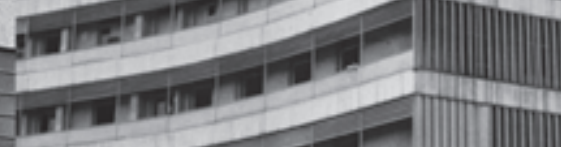

-

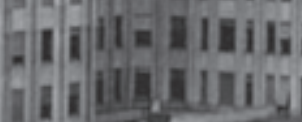
III IIIII

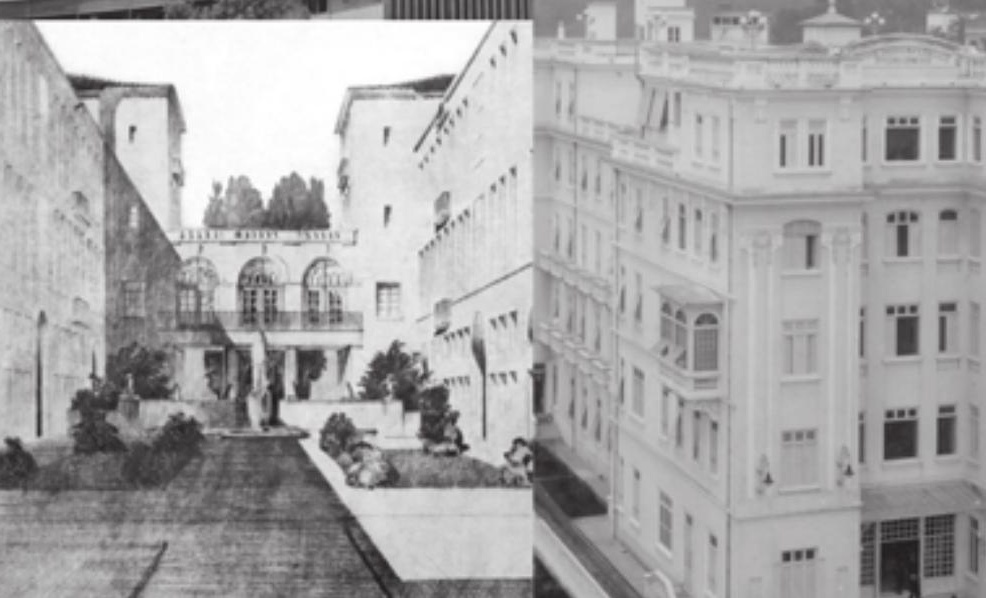




\section{Instituições/Edificações Descritas no CD-ROM}

\section{Do período imperial}

Academia Nacional de Medicina

Casa de Banhos de D. João VI

Casa de Saúde Dr. Eiras

Casa de Saúde São Sebastião

Faculdade de Medicina da Universidade Federal do Rio de Janeiro

Hospital Central da Marinha

Hospital Central da Polícia Militar

Hospital Central do Exército

Hospital da Beneficência Portuguesa

Hospital da Venerável e Arquiepiscopal Ordem Terceira N. Sra. do Monte do Carmo

Hospital da Venerável Ordem Terceira de São Francisco da Penitência

Hospital Frei Antonio

Instituto Benjamin Constant

Instituto Estadual de Infectologia São Sebastião (Ieess)

Instituto Hahnemanniano do Brasil

Instituto Nacional de Educação de Surdos (Ines)

Instituto Pasteur do Rio de Janeiro

Policlínica Geral do Rio de Janeiro

Real e Benemérita Sociedade Portuguesa Caixa de Socorros D. Pedro V

Sociedade de Medicina e Cirurgia do Rio de Janeiro

Santa Casa da Misericórdia

- Hospício de São João Batista

- Hospital de N. Sra. do Socorro

- Hospital Geral da Santa Casa da Misericórdia do Rio de Janeiro

- Hospital José Carlos Rodrigues

- Hospital N. Sra. da Saúde

- Hospital N. Sra. das Dores

- Hospital São Zacharias

- Palácio Universitário 


\section{Do período da $1^{a}$ República}

Casa de Saúde São José

Cruz Vermelha Brasileira

Escola de Enfermagem Alfredo Pinto da Universidade Federal do Estado do Rio de Janeiro

Escola de Enfermagem Anna Nery

Escola de Medicina e Cirurgia da Universidade Federal do Estado do Rio de Janeiro

Fundação Ataulpho de Paiva

Fundação Oswaldo Cruz

- Fundação Oswaldo Cruz

- Hospital Evandro Chagas

- Instituto Fernandes Figueira

- Posto Avançado da Fiocruz em Jacarepaguá

Hospital Central Aristarcho Pessoa

Hospital do Amparo Feminino

Hospital e Maternidade Casa de Portugal

Hospital Espanhol

Hospital Estadual Pedro II

Hospital Evangélico do Rio de Janeiro

Hospital Israelita Albert Sabin

Hospital-Maternidade Herculano Pinheiro

Hospital Moncorvo Filho/Instituto Estadual de Diabetes e Endocrinologia Luiz Capriglione

Hospital Municipal Barata Ribeiro

Hospital Municipal Souza Aguiar

Hospital São Francisco de Assis

Hospital Universitário Gaffrée \& Guinle

Instituto Estadual de Dermatologia Sanitária

Instituto Municipal de Assistência à Saúde Juliano Moreira

Instituto Municipal de Assistência à Saúde Nise da Silveira

Laboratório de Análises

Maternidade-Escola da Universidade Federal do Rio de Janeiro

Policlínica de Botafogo

Pro Matre

\section{Do período de 1930 a 1958}

Associação Brasileira Beneficente de Reabilitação (ABBR)

Casa de Saúde Santa Lúcia

Clínica São Vicente

Faculdade de Ciências Médicas da Universidade do Estado do Rio de Janeiro

Faculdade de Enfermagem Luiza de Marillac

Hospital Adventista Silvestre (HAS) 
Hospital Cardoso Fontes

Hospital Central da Aeronáutica

Hospital Central do Instituto de Assistência dos Servidores do Estado do Rio de Janeiro (Iaserj)

Hospital de Ipanema

Hospital do Andaraí

Hospital dos Servidores do Estado

Hospital Estadual Anchieta

Hospital Estadual Carlos Chagas

Hospital Estadual Getulio Vargas

Hospital Estadual Rocha Faria

Hospital Estadual Santa Maria

Hospital Geral da Lagoa

Hospital Geral de Bonsucesso

Hospital Municipal Carmela Dutra

Hospital Municipal Jesus

Hospital Municipal Lourenço Jorge

Hospital Municipal Miguel Couto

Hospital Municipal Nossa Senhora do Loreto

Hospital Municipal Oswaldo Nazareth

Hospital Municipal Paulino Werneck

Hospital Municipal Raphael de Paula Souza

Hospital Municipal Rocha Maia

Hospital Municipal Salgado Filho

Hospital Municipal Salles Netto

Hospital São Lucas

Hospital Universitário Pedro Ernesto (Hupe)

Hospital-Maternidade Alexander Fleming

Hospital-Maternidade Carmela Dutra

Hospital-Maternidade Herculano Pinheiro

Instituto de Hematologia Arthur de Siqueira Cavalcanti (Hemorio)

Instituto de Psiquiatria da Universidade Federal do Rio de Janeiro

Instituto de Puericultura e Pediatria Martagão Gesteira (IPPMG)

Instituto Estadual de Cardiologia Aloysio de Castro

Instituto Municipal da Mulher Fernando Magalhães

Instituto Municipal de Medicina Física e Reabilitação Oscar Clark

Instituto Municipal Dr. Philippe Pinel

Instituto Nacional de Câncer (INCa)

- Centro de Reabilitação do Instituto Nacional de Câncer

- Instituto Nacional de Câncer (INCa)

Instituto Nacional de Cardiologia

Instituto Nacional de Traumatologia e Ortopedia

Laboratório Central de Saúde Pública Noel Nutels

Unidade Integrada de Saúde Manoel Arthur Villaboim 
Formato: $21 \times 26 \mathrm{~cm}$

Tipologia: Stone Serif ITC e Myriad Pro (capa e miolo)

Papel: Printmax $90 \mathrm{~g} / \mathrm{m}^{2}$ (miolo)

Capa: Supremo $250 \mathrm{~g} / \mathrm{m}^{2}$ (capa)

CTP, impressão e acabamento: Imprinta Express Gráfica e Editora Ltda.

Rio de Janeiro, dezembro 2008

Não encontrando nossos títulos em livrarias, contactar a Editora Fiocruz

Av. Brasil, $4036-1^{\circ}$ andar, sala 112 - Manguinhos

21040-361 - Rio de Janeiro/RJ

Tel.: (21) 3882-9039 e 3882-9041

Telefax: (21) 3882-9006

e-mail: editora@fiocruz.br

http://www.fiocruz.br/editora 